Supporting Information for

\title{
Sulfurane [S(IV)]-mediated fusion of benzynes leads to helical dibenzofurans
}

\author{
Casey B. Ritts and Thomas R. Hoye* \\ Department of Chemistry, 207 Pleasant Street, SE, \\ University of Minnesota, Minneapolis, Minnesota 55455, USA \\ hoye@umn.edu
}

\section{Contents of Supporting Information}

Contents

I. General experimental protocols

II. General procedures A-C

III. Procedures for preparation and characterization data for all new compounds

IV. Reaction optimization for dibenzofuran synthesis

V. Computational methods, discussion, and results

Methods

Methods check for calculating tetraaryl $\sigma$-sulfuranes

Discussion (Figure S1)

Energies and Cartesian coordinates

Individual structures
Page \#

S1-S2

S3

S4

S5-S22

S23

S24-S83

S24

S24

S25

S25

S26-S83

S84-S87

S88

S89-S147

S89-S90

S91-S92

S93-S94

S95-S96

S97-S98

S99-S102

S103-S108

S109

S110-S111

S112-S115

S116-S117

S118-S119

S120-S121 
${ }^{1} \mathrm{H}$ and ${ }^{13} \mathrm{C}$ for 14

S122-S123

${ }^{1} \mathrm{H}$ and ${ }^{13} \mathrm{C}$ for $15-\mathrm{S}$

S124-S125

${ }^{1} \mathrm{H},{ }^{13} \mathrm{C}$, and ${ }^{19} \mathrm{~F}$ for 16

S126-S128

${ }^{1} \mathrm{H},{ }^{13} \mathrm{C},{ }^{19} \mathrm{~F}, \mathrm{HSQC}$, and $\mathrm{HMBC}$ for $\mathbf{1 7}-\mathrm{S}$

S129-S133

${ }^{1} \mathrm{H},{ }^{13} \mathrm{C}, \mathrm{HSQC}, \mathrm{HMBC}$, and NOESY for 19-S

S134-S138

${ }^{1} \mathrm{H},{ }^{13} \mathrm{C}, \mathrm{HSQC}$, and $\mathrm{HMBC}$ for 20

S139-S142

${ }^{1} \mathrm{H},{ }^{13} \mathrm{C}$, NOESY, HSQC, and HMBC for 21

S143-S147 


\section{General experimental protocols}

${ }^{13} \mathrm{C},{ }^{19} \mathrm{~F}$, and ${ }^{1} \mathrm{H}$ NMR spectra were measured on a Bruker Avance III (HD-500) spectrometer. Chemical shifts for spectra in $\mathrm{CDCl}_{3}$ are referenced to $\mathrm{CHCl}_{3}$ at $\delta 7.26$ or, when TMS was present, to the TMS resonance at $\delta 0.00 \mathrm{ppm}$. A non-first order multiplet or doublet in a ${ }^{1} \mathrm{H}$ NMR spectrum is denoted as 'nfom' or 'nfod', respectively. Multiplets are described according to the following format: the chemical shift (ppm) [the multiplicity, the coupling constant(s) in $\mathrm{Hz}$, the integral value (to the nearest integer), and the assignment of the environment within the structure]. This is done either by indicating neighboring atoms or by numbering of the carbon atom to which the proton is attached, as indicated by numbers on the structure (which do not necessarily follow the numbering of the nomenclature). Analysis of coupling constants was performed with methods published previously. ${ }^{1,2}{ }^{13} \mathrm{C}$ NMR chemical shifts come either from 1D spectra or, when solubility or sample quantity was limited, from $\mathrm{HMBC} / \mathrm{HSQC}$ data. Carbon chemical shifts in $\mathrm{CDCl}_{3}$ are referenced to the carbon to $\delta 77.16 \mathrm{ppm}$. ${ }^{19} \mathrm{~F}$ spectra were of $\mathrm{CDCl}_{3}$ solutions doped with $\mathrm{C}_{6} \mathrm{~F}_{6}$, and the chemical shift of the dopant was referenced to $\delta-161.64$ ppm. $^{3}$

Infrared spectra were measured on a Bruker Alpha II Spectrometer. Attenuated total reflectance (ATR) mode was used. Selected absorption maxima are given in $\mathrm{cm}^{-1}$. The samples were deposited on the diamond window by evaporation of a methylene chloride solution of the analyte.

High-resolution mass spectrometry (HRMS) was performed in ESI or APCl ionization mode, as indicated, with a Thermo Orbitrap Velos instrument (mass accuracy of $\leq 3 \mathrm{ppm}$ ). An external calibrant (Pierce ${ }^{\mathrm{TM}} \mathrm{LTQ}$ ) was used. The samples were delivered directly into the ion source.

Thin layer chromatography (TLC) was carried out using silica-gel coated, aluminum-backed plates that were visualized first by UV light and, then, by staining with a solution of $\mathrm{KMnO}_{4}$ and heating.

"Medium pressure liquid chromatography (MPLC) was used to purify most new compounds. Hand-packed silica gel columns (Teledyne RediSep Rf Gold ${ }^{\circledR}$; normal-phase, 20-40 $\mu \mathrm{m}, 60 \AA$ pore size,) were used. The apparatus was constructed with a HPLC pump (Waters model 510), differential refractive index detector (Waters R401), and UV detector (Gilson 111 UV). Preparative flash chromatography was done on Agela silica gel (230-400 mesh)." 4

Reaction temperatures refer to the temperature of an external heating (sand) bath or block heater. Reactions, including those at temperatures higher than the boiling point of the solvent, were carried out in a screw-top culture tube that was secured with an inert (Teflon ${ }^{\circledR}$-lined) closure.

Poly-yne substrates $\mathbf{7}^{5}$ and $1 \mathbf{8}^{6}$ and diaryl sulfoxides $\mathbf{2} \mathbf{b}^{\mathbf{7}}, \mathbf{2} \mathrm{c}^{\mathbf{8}}$, and $\mathbf{2} \mathrm{d}^{7}$ were synthesized according to reported methods. 


\section{General procedures A-C}

\section{A. General procedure for the Cadiot-Chodkiewicz alkyne/bromoalkyne cross-coupling reaction}

Cuprous(I) chloride ( 0.10 equiv relative to the terminal alkyne substrate) and $\mathrm{NH}_{2} \mathrm{OH} \cdot \mathrm{HCl}$ (ca. 0.20 equiv) were placed in a roundbottomed flask. The flask was evacuated and back-filled with nitrogen gas $(3 \mathrm{x})$ and closed with a septum. A balloon of nitrogen gas was inserted, and the flask was cooled to $0{ }^{\circ} \mathrm{C}$ (ice water bath). A solution of $70: 30$ (v/v) $\mathrm{H}_{2} \mathrm{O} / n-\mathrm{BuNH}_{2}$ was added to the flask and this mixture was stirred for $15 \mathrm{~min}$ at the same temperature. The color of this solution quickly changed from deep blue/green to colorless, indicating conversion of any $\mathrm{Cu}(\mathrm{II})$ to $\mathrm{Cu}(\mathrm{I})$. A small portion of the terminal alkyne in $\mathrm{CH}_{2} \mathrm{Cl}_{2}$ (ca. 0.10 equiv, ca. $2.5 \mathrm{~mL} / \mathrm{mmol}$ ) was added to the reaction flask and a yellow precipitate quickly appeared. A solution of the remaining terminal alkyne ( 0.9 equiv) and the 1-bromoalkyne (1.1-2.2 equiv) in 9:1 v/v CH $\mathrm{Cl}_{2} / \mathrm{MeOH}$ (ca. $2.5 \mathrm{~mL} / \mathrm{mmol}$ ) was injected dropwise over ca. $15 \mathrm{~min}$. The resulting mixture was stirred at $0{ }^{\circ} \mathrm{C}$ for no more than $1.5 \mathrm{~h}$. The suspension of the alkynyl copper species would typically turn to a clear, twolayer mixture over the course of 10-90 min, indicating consumption of the sparingly soluble alkynyl copper species. The reaction mixture was quenched by the addition of satd. aq. $\mathrm{NH}_{4} \mathrm{Cl}$ and then extracted with $\mathrm{CH}_{2} \mathrm{Cl}_{2}$. The combined extracts were dried, filtered, and concentrated. The residue was purified by flash chromatography (or MPLC) on silica gel or precipitated from $\mathrm{CH}_{2} \mathrm{Cl}_{2} \mathrm{using} \mathrm{MeOH}$.

\section{B. General procedure for the oxidation of benzylic \& propargylic alcohols}

A solution of the benzylic/propargylic alcohol in $\mathrm{CH}_{2} \mathrm{Cl}_{2}(0.20 \mathrm{M})$ was charged either to a threaded vial or a round-bottom flask. Activated $\mathrm{MnO}_{2}$ powder* (10.0 equiv relative to the alcohol substrate) was added to the vessel, which was lightly capped. The reaction was stirred at room temperature for $2 \mathrm{~h}$. The reaction mixture was then filtered through a silica plug and flushed through with EtOAc. The filtrate was concentrated and used without further purification.

* "Activated" $\mathrm{MnO}_{2}$ ( $\leq 10 \mu \mathrm{m}$ particle size, Alfa Aesar) was further activated by heating to $250{ }^{\circ} \mathrm{C}$ for several hours and cooled and stored in a desiccator for subsequent use.

\section{General procedure for synthesis of dibenzofurans}

The polyyne precursor (2.2 equiv) and the diaryl sulfoxide (1.0 equiv) were combined in a screw-top culture tube. 1,2-Dichloroethane (DCE) was added to bring the solution to an initial concentration of the polyyne of $0.22 \mathrm{M}$. The headspace of the tube was flushed with nitrogen gas and the resulting solution was placed in a sand bath maintained at $120{ }^{\circ} \mathrm{C}$ and allowed to react for $1-24 \mathrm{~h}$. After cooling to room temperature, the reaction mixture was then purified either by a) precipitation from $\mathrm{CH}_{2} \mathrm{Cl}_{2}$ using $\mathrm{MeOH}$ followed by filtration or b) solvent removal reduced pressure followed by purification using MPLC with the indicated elution solvent system. 


\section{Procedures for preparation and characterization data for all new compounds}

(士)-1-(2-((4-Methoxyphenyl)buta-1,3-diyn-1-yl)phenyl)-3-(trimethylsilyl)prop-2-yn-1-ol (S3)

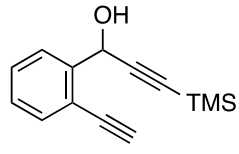

S1

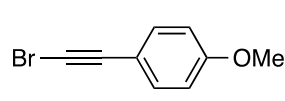

S2

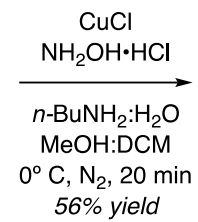

$56 \%$ yield

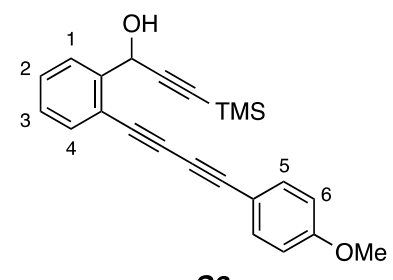

S3

General procedure A was followed using 1-(2-ethynylphenyl)-3-(trimethylsilyl)prop-2-yn-1-ol ${ }^{5}$ (S1, 206 mg, 0.75 mmol, 1.0 equiv) and 1-(bromoethynyl)-4-methoxybenzene ${ }^{9}(\mathbf{S} 2,174 \mathrm{mg}, 0.83 \mathrm{mmol}, 1.1$ equiv) to prepare the triyne S3. Purification by MPLC (11:1 hexanes:EtOAc) yielded $\mathbf{S} 3$ (150 $\mathrm{mg}, 0.42 \mathrm{mmol}, 56 \%)$ as an amber viscous oil.

\section{Data for triyne S3:}

${ }^{1} \mathrm{H}$ NMR $\left(500 \mathrm{MHz}, \mathrm{CDCl}_{3}\right): \delta 7.72(\mathrm{dd}, J=7.9,1.0 \mathrm{~Hz}, 1 \mathrm{H}, H 1), 7.55$ (dd, $\left.J=7.7,1.4 \mathrm{~Hz}, 1 \mathrm{H}, H 4\right), 7.48$ (nfod, Japp $=8.8 \mathrm{~Hz}, 2 \mathrm{H}$, $H 5 / 5^{\prime}$ ), 7.41 (ddd, $J=7.6,7.6,1.4 \mathrm{~Hz}, 1 \mathrm{H}, H 2,7.31$ (ddd, $J=7.6,7.6,1.3 \mathrm{~Hz}, 1 \mathrm{H}, H 3$ ), 6.87 (nfod, Japp = 8.8 Hz, 2H, H6/6'), 5.87 [d, $J=5.7 \mathrm{~Hz}, 1 \mathrm{H}, \mathrm{Ar}(\mathrm{CC}) \mathrm{CHOH}$ ], $3.83\left(\mathrm{~s}, 3 \mathrm{H}, \mathrm{OCH}_{3}\right), 2.48(\mathrm{~d}, J=5.7 \mathrm{~Hz}, 1 \mathrm{H}, \mathrm{OH})$, and $0.21\left[\mathrm{~s}, 9 \mathrm{H}, \mathrm{Si}\left(\mathrm{CH}_{3}\right)_{3}\right]$.

${ }^{13} \mathrm{C}$ NMR $\left(125 \mathrm{MHz}, \mathrm{CDCl}_{3}\right): \delta 160.7,143.4,134.3,133.7,129.7,128.5,127.1,120.8,114.4,113.7,104.2,92.1,83.5,79.6,78.2$, 72.7, 63.6, 55.5, and 0.0.

HRMS (ESI-TOF) m/z: Calcd for $\mathrm{C}_{23} \mathrm{H}_{21} \mathrm{OSi}^{+}\left[\mathrm{M}+\mathrm{H}^{+}-\mathrm{H}_{2} \mathrm{O}\right.$ ] requires 341.1362; found 341.1349.

IR (neat): 3428, 2958, 2213, 1601, 1509, 1248, and $1031 \mathrm{~cm}^{-1}$. 


\section{1-(2-((4-Methoxyphenyl)buta-1,3-diyn-1-yl)phenyl)-3-(trimethylsilyl)prop-2-yn-1-one (10)}
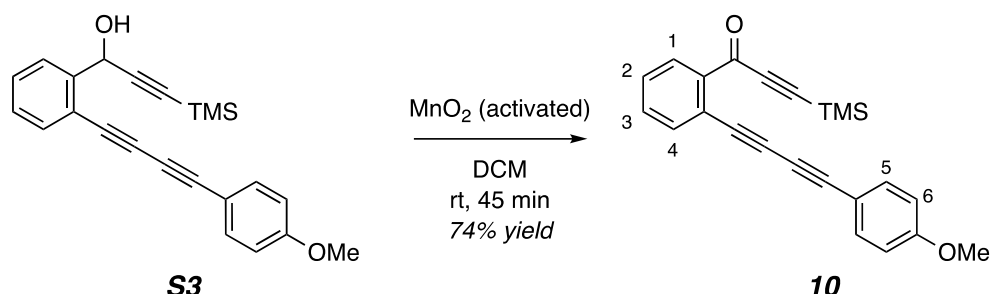

S3

10

General procedure B was followed using 1-(2-((4-methoxyphenyl)buta-1,3-diyn-1-yl)phenyl)-3-(trimethylsilyl)prop-2-yn-1-ol (S3, 175 $\mathrm{mg}, 0.49 \mathrm{mmol}, 1.0$ equiv) and activated $\mathrm{MnO}_{2}$ powder $(410 \mathrm{mg}, 4.90 \mathrm{mmol}, 10.0$ equiv) to prepare the ynone 10. This procedure yielded 10 (133 mg, $0.37 \mathrm{mmol}, 74 \%$ ) as a reddish-brown oil and was stored in the refrigerator immediately after isolation.

\section{Data for ynone 10:}

${ }^{1} \mathrm{H}$ NMR $\left(500 \mathrm{MHz}, \mathrm{CDCl}_{3}\right): \delta 8.10$ (dd, $\left.J=7.8,1.2 \mathrm{~Hz}, 1 \mathrm{H}, H 1\right), 7.64$ (dd, $\left.J=7.7,1.1 \mathrm{~Hz}, 1 \mathrm{H}, H 4\right), 7.52$ (ddd, $J=7.5,7.5,1.3 \mathrm{~Hz}$, $1 \mathrm{H}, H 3$ ), 7.47 (nfod, $J_{a p p}=8.8 \mathrm{~Hz}, 2 \mathrm{H}, H 5 / 5^{\prime}$ ), 7.46 (ddd, $J=7.6,7.6,1.3 \mathrm{~Hz}, 1 \mathrm{H}, H 2$ ), 6.86 (nfod, Japp $=8.8 \mathrm{~Hz}, 2 \mathrm{H}, H 6 / 6^{\prime}$ ), 3.82 (s, $\left.3 \mathrm{H}, \mathrm{OCH}_{3}\right)$, and $0.32\left[\mathrm{~s}, 9 \mathrm{H}, \mathrm{Si}\left(\mathrm{CH}_{3}\right)_{3}\right]$.

${ }^{13} \mathrm{C}$ NMR $\left(125 \mathrm{MHz}, \mathrm{CDCl}_{3}\right): \delta 176.7,160.6,139.0,136.6,134.4,132.7,131.9,128.7,122.2,114.3,113.8,101.7,101.6,84.2,80.6$, $79.2,73.4,55.5$, and -0.5 .

HRMS (ESI-TOF) m/z: Calcd for $\mathrm{C}_{23} \mathrm{H}_{21} \mathrm{O}_{2} \mathrm{Si}^{+}\left[\mathrm{M}+\mathrm{H}^{+}\right]$requires 357.1311; found 357.1298.

IR (neat): 2958, 2900, 2838, 2207, 1709, 1602, 1510, 1248, and $1172 \mathrm{~cm}^{-1}$. 


\section{(士)-1-(1-Ethynylnaphthalen-2-yl)-3-(trimethylsilyl)prop-2-yn-1-ol (S5)}

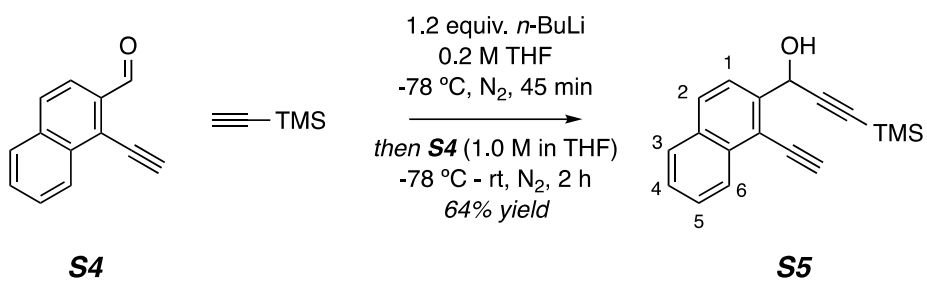

Trimethylsilylacetylene ( $435 \mu \mathrm{L}, 3.05 \mathrm{mmol}, 1.1$ equiv) and anhydrous THF (6 mL) were charged to a flame-dried, round-bottom flask under a nitrogen gas atmosphere. The flask was cooled in a dry ice/acetone bath and $n$-BuLi (1.33 mL, $3.33 \mathrm{mmol}, 1.2$ equiv, $2.5 \mathrm{M}$ in hexanes) was added dropwise. The reaction mixture was stirred for $45 \mathrm{~min}$ at the same temperature before a solution of 1-ethynyl2-naphthaldehyde ${ }^{10}(\mathbf{S} 4,500 \mathrm{mg}, 2.78 \mathrm{mmol}, 1.0$ equiv, $1.0 \mathrm{M} \mathrm{in} \mathrm{THF)}$ was added dropwise to the reaction flask. The reaction solution was allowed to stir and warm gradually to room temperature over $2 \mathrm{~h}$ before being carefully quenched by the addition of satd. aq. $\mathrm{NH}_{4} \mathrm{Cl}$ and then extracted with EtOAc. The combined extracts were dried, filtered, and concentrated. Purification by flash chromatography (9:1 hexane:EtOAc) afforded diyne $\mathbf{S 5}(495 \mathrm{mg}, 1.78 \mathrm{mmol}, 64 \%)$ as a viscous yellow oil.

\section{Data for diyne S5:}

${ }^{1} \mathrm{H}$ NMR $\left(500 \mathrm{MHz}, \mathrm{CDCl}_{3}\right): \delta 8.39$ (dddd, $J=8.4,1.4,0.7,0.7 \mathrm{~Hz}, 1 \mathrm{H}, \mathrm{H6}$ ), 7.88 (br d, $\left.J=8.6 \mathrm{~Hz}, 1 \mathrm{H}, H 2\right), 7.87$ (d, $J=8.6 \mathrm{~Hz}, 1 \mathrm{H}$, $H 1$ ), 7.83 (dddd, $J=8.1,2.4,1.0,1.0 \mathrm{~Hz}, 1 \mathrm{H}, H 3$ ), 7.60 (ddd, $J=8.4,7.6,1.3 \mathrm{~Hz}, 1 \mathrm{H}, H 4$ or H5), 7.53 (nfom, $1 \mathrm{H}, H 4$ or H5), 6.21 [d, $J=4.9 \mathrm{~Hz}, 1 \mathrm{H}, \operatorname{Ar}(\mathrm{CC}) \mathrm{CHOH}$ ], $3.79(\mathrm{~s}, 1 \mathrm{H}, \operatorname{ArCCH}), 2.86(\mathrm{~m}, 1 \mathrm{H}, \mathrm{OH})$, and $0.24\left[\mathrm{~s}, 9 \mathrm{H}, \mathrm{Si}\left(\mathrm{CH}_{3}\right)_{3}\right]$.

${ }^{13} \mathrm{C}$ NMR $\left(125 \mathrm{MHz}, \mathrm{CDCl}_{3}\right): \delta 141.7,133.5,132.9,129.8,128.2,127.4,126.9,126.5,124.1,117.8,104.6,91.9,88.1,79.0,63.7$, and -0.1 .

HRMS (ESI-TOF) m/z: [M + $\left.\mathrm{H}^{+}\right]$Calcd for $\mathrm{C}_{18} \mathrm{H}_{19} \mathrm{OSi}{ }^{+}$requires 279.1205; found 279.1194.

IR (neat): 3295, 3060, 2961, 1250, and $1039 \mathrm{~cm}^{-1}$. 


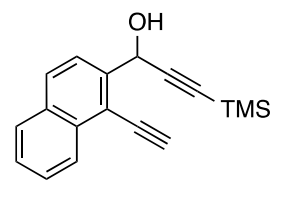

S5

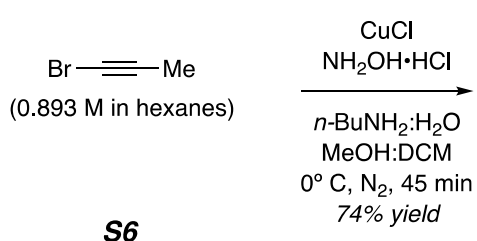

s6

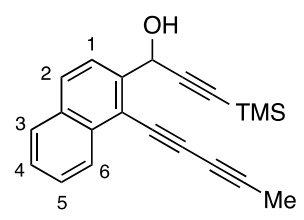

S7

General procedure A was followed using 1-(1-ethynylnaphthalen-2-yl)-3-(trimethylsilyl)prop-2-yn-1-ol (S5, 126 mg, 0.46 mmol, 1.0 equiv) and 1-bromoprop-1-yne (S6, $560 \mu \mathrm{L}, 0.50 \mathrm{mmol}, 1.1$ equiv, $0.893 \mathrm{M}$ in hexanes) to prepare the triyne S7. Purification by MPLC (9:1 hexanes:EtOAc) yielded $\mathbf{S 7}$ (106 $\mathrm{mg}, 0.34 \mathrm{mmol}, 74 \%)$ as a dark red viscous oil.

\section{Data for triyne S7:}

${ }^{1} \mathrm{H}$ NMR $\left(500 \mathrm{MHz}, \mathrm{CDCl}_{3}\right.$ ): $\delta 8.34$ (dddd, $\left.J=8.4,1.4,0.9,0.9 \mathrm{~Hz}, 1 \mathrm{H}, \mathrm{H} 6\right), 7.88$ (br d, $\left.J=8.6,0.6 \mathrm{~Hz}, 1 \mathrm{H}, H 2\right), 7.83$ (ddd, $J=8.2$, $1.4,0.6 \mathrm{~Hz}, 1 \mathrm{H}, H 3), 7.82(\mathrm{~d}, J=8.5 \mathrm{~Hz}, 1 \mathrm{H}, H 1), 7.59$ (ddd, J=8.2, 6.9, $1.4 \mathrm{~Hz}, 1 \mathrm{H}, \mathrm{H} 4$ or 5 ), 7.53 (ddd, J=8.2, $6.9,1.4 \mathrm{~Hz}, 1 \mathrm{H}, H 4$ or 5), $6.13[\mathrm{~d}, J=5.1 \mathrm{~Hz}, 1 \mathrm{H}, \operatorname{Ar}(\mathrm{CC}) \mathrm{CHOH}], 2.58(\mathrm{~m}, 1 \mathrm{H}, \mathrm{OH}), 2.10\left[\mathrm{~s}, 1 \mathrm{H}, \operatorname{Ar}(\mathrm{CC}) \mathrm{CH}_{3}\right]$, and $0.21\left[\mathrm{~s}, 9 \mathrm{H}, \mathrm{Si}(\mathrm{CH})_{3}\right]$.

${ }^{13} \mathrm{C}$ NMR $\left(125 \mathrm{MHz}_{\mathrm{CDCl}}\right): \delta 142.8,134.2,132.9,129.8,128.4,127.4,127.0,126.6,124.2,118.0,104.5,92.0,85.0,83.3,69.4$, $64.5,63.8,4.9$, and -0.1 .

HRMS (ESI-TOF) $m / z$ : [M + $\left.\mathrm{H}^{+}-\mathrm{H}_{2} \mathrm{O}\right]$ Calcd for $\mathrm{C}_{21} \mathrm{H}_{19} \mathrm{Si}^{+}$requires 299.1256; found 299.1244.

IR (neat): 3398, 2959, 2900, 1708, 1250, and $1033 \mathrm{~cm}^{-1}$. 


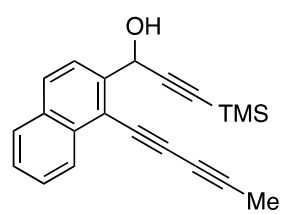

57

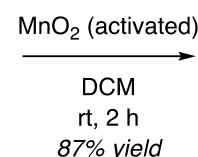

$87 \%$ yield

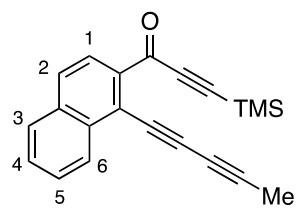

12

General procedure B was followed using 1-(1-(penta-1,3-diyn-1-yl)naphthalen-2-yl)-3-(trimethylsilyl)prop-2-yn-1-ol (S7, 106 mg, 0.34 mmol, 1.0 equiv) and activated $\mathrm{MnO}_{2}$ powder (296 mg, $3.40 \mathrm{mmol}, 10.0$ equiv) to prepare the ynone 12 . This procedure yielded 12 (93 $\mathrm{mg}, 0.30 \mathrm{mmol}, 87 \%$ ) as a dark brown viscous oil.

\section{Data for ynone 12:}

${ }^{1} \mathbf{H}$ NMR $\left(500 \mathrm{MHz}_{\mathrm{CDCl}}\right.$ ): $\delta 8.53$ (nfom, $1 \mathrm{H}, \mathrm{H6}$ ), 8.06 (d, $\left.\mathrm{J}=8.7 \mathrm{~Hz}, 1 \mathrm{H}, H 1\right), 7.88-7.84$ (m, 2H, H2 and H3), 7.64 (ddd, $J=8.5$, 6.8, $1.6 \mathrm{~Hz}, 1 \mathrm{H}, \mathrm{H} 4$ or $H 5), 7.62$ (ddd, $J=8.5,6.9,1.6 \mathrm{~Hz}, 1 \mathrm{H}, H 4$ or $H 5), 2.11$ [s, $1 \mathrm{H}, \operatorname{Ar}(\mathrm{CC}) \mathrm{CH}_{3}$ ], and 0.33 [s, $\left.9 \mathrm{H}, \mathrm{Si}\left(\mathrm{CH}_{3}\right) 3\right]$.

${ }^{13} \mathrm{C}$ NMR $\left(125 \mathrm{MHz}, \mathrm{CDCl}_{3}\right): \delta 177.4,138.2,134.9,134.7,129.0,128.8,128.4,128.1,127.9,126.3,121.3,102.3,102.2,87.6,84.7$, $70.1,65.2,5.1$, and -0.5 .

HRMS (ESI-TOF) m/z: [M + $\mathrm{H}^{+}$] Calcd for $\mathrm{C}_{21} \mathrm{H}_{19} \mathrm{OSi}{ }^{+}$requires 315.1205; found 315.1192.

IR (neat): 3056, 2955, 2898, 1706, 1577, 1368, and $1248 \mathrm{~cm}^{-1}$. 


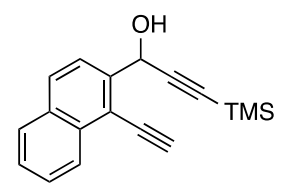

S5

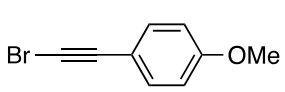

S2

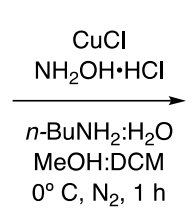

$0^{\circ} \mathrm{C}, \mathrm{N}_{2}, 1 \mathrm{~h}$

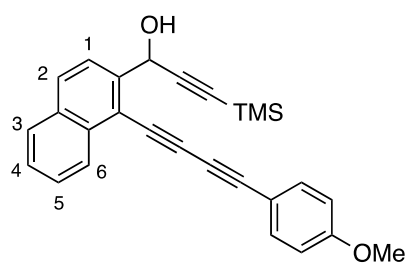

S8

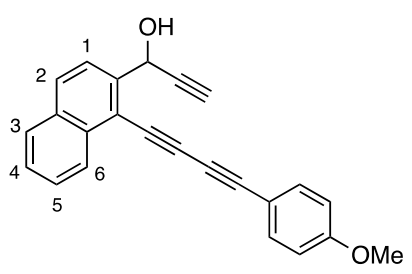

s9

General procedure A was followed using 1-(1-ethynylnaphthalen-2-yl)-3-(trimethylsilyl)prop-2-yn-1-ol (S5, 235 mg, 0.85 mmol, 1.0 equiv) and 1-(bromoethynyl)-4-methoxybenzene (S2, $196 \mathrm{mg}, 0.93 \mathrm{mmol}, 1.1$ equiv) to prepare triynes $\mathbf{S} 8$ and $\mathbf{S 9}$. Purification by MPLC (7:1 hexanes:EtOAc) yielded, in order of elution, $\mathbf{S} 8(215 \mathrm{mg}, 0.53 \mathrm{mmol}, 62 \%)$ as a crystalline, off-white solid and $\mathbf{S 9}$ (36 mg, $0.11 \mathrm{mmol}, 13 \%)$ as an orange crystalline solid.

\section{Data for triyne S8:}

${ }^{1} \mathrm{H}$ NMR $\left(500 \mathrm{MHz}, \mathrm{CDCl}_{3}\right): \delta 8.40$ (dd, $J=8.5,1.3,0.8,0.8 \mathrm{~Hz}, 1 \mathrm{H}, \mathrm{H6}$ ), 7.90 (dd, $J=8.6,0.7 \mathrm{~Hz}, 1 \mathrm{H}, \mathrm{H} 2$ ), 7.86 (overlapped m, $1 \mathrm{H}$, $H 3$ ), 7.85 (d, $J=8.6 \mathrm{~Hz}, 1 \mathrm{H}, H 1$ ), 7.61 (ddd, $J=8.3,6.8,1.3 \mathrm{~Hz}, 1 \mathrm{H}, \mathrm{H} 4$ or $H 5$ ), 7.54 (ddd, $J=$ overlapped, $6.8,1.3 \mathrm{~Hz}, 1 \mathrm{H}, \mathrm{H4}$ or H5), 7.53 [nfod, Japp $=8.9 \mathrm{~Hz}, 2 \mathrm{H},(\mathrm{m}-\mathrm{OMe}) \mathrm{PhH}$ ], 6.90 [nfod, Japp $=8.9 \mathrm{~Hz}, 2 \mathrm{H},(\mathrm{o}-\mathrm{OMe}) \mathrm{PhH}, 6.18(\mathrm{~s}, 1 \mathrm{H}, \operatorname{Ar}(\mathrm{CC}) \mathrm{CHOH}), 3.85(\mathrm{~s}$, $\left.3 \mathrm{H}, \mathrm{ArOCH}_{3}\right), 2.64(\mathrm{br} \mathrm{s}, 1 \mathrm{H}, \mathrm{OH})$, and $0.20\left[\mathrm{~s}, 9 \mathrm{H}, \mathrm{Si}\left(\mathrm{CH}_{3}\right)_{3}\right]$.

${ }^{13} \mathrm{C}$ NMR $\left(125 \mathrm{MHz}, \mathrm{CDCl}_{3}\right): \delta$ 160.7, 142.8, 134.3, 134.1, 133.0, 130.0, 128.4, 127.6, 127.1, 126.7, 124.3, 118.0, 114.4, 113.7, 104.6, $92.1,84.7,84.6,76.3,72.9,63.9,55.5$, and 0.0 .

HRMS (APCl) $m / z:\left[\mathrm{M}+\mathrm{H}^{+}-\mathrm{H}_{2} \mathrm{O}\right]^{+}$Calcd for $\mathrm{C}_{27} \mathrm{H}_{23} \mathrm{OSi}{ }^{+}$requires 391.1518; found 391.1504.

IR (neat): $3428,2959,2221,1603,1509,1251,1171$, and $1030 \mathrm{~cm}^{-1}$.

$\mathrm{mp}: 87-89^{\circ} \mathrm{C}$.

\section{Data for triyne S9:}

${ }^{1} \mathrm{H}$ NMR $\left(500 \mathrm{MHz}, \mathrm{CDCl}_{3}\right): \delta 8.39$ (dddd, $\left.J=8.4,1.1,0.8,0.8 \mathrm{~Hz}, 1 \mathrm{H}, H 6\right), 7.90$ (dd, $\left.J=8.6,0.8 \mathrm{~Hz}, 1 \mathrm{H}, H 2\right), 7.86(\mathrm{~d}, J=8.6 \mathrm{~Hz}$, $1 \mathrm{H}, H 1$ ), 7.85 (dddd, $J=8.1,1.2,0.6,0.6 \mathrm{~Hz}, 1 \mathrm{H}, H 3), 7.61$ (ddd, $J=8.2,6.8,1.3 \mathrm{~Hz}, 1 \mathrm{H}, \mathrm{H} 4$ or H5), 7.54 (ddd, $J=8.1,6.9,1.3 \mathrm{~Hz}$, $1 \mathrm{H}, \mathrm{H} 4$ or H5), 7.53 [nfod, Japp $=9.0 \mathrm{~Hz}, 2 \mathrm{H},(m-\mathrm{OMe}) \mathrm{PhH}$ ], 6.89 [nfod, Japp $=9.0 \mathrm{~Hz}, 2 \mathrm{H},(o-\mathrm{OMe}) \mathrm{PhH}, 6.21[\mathrm{dd}, J=5.0,2.3 \mathrm{~Hz}, 1 \mathrm{H}$, $\operatorname{Ar}(\mathrm{CC}) \mathrm{CHOH}], 3.85\left(\mathrm{~s}, 3 \mathrm{H}, \mathrm{ArOCH}_{3}\right), 2.70(\mathrm{~d}, J=2.3 \mathrm{~Hz}, 1 \mathrm{H}, \mathrm{CCH})$, and $2.51(\mathrm{~d}, J=5.1 \mathrm{~Hz}, 1 \mathrm{H}, \mathrm{OH})$.

${ }^{13} \mathrm{C} \mathrm{NMR}\left(125 \mathrm{MHz}, \mathrm{CDCl}_{3}\right): \delta 160.7,142.3,134.4,134.1,133.0,130.1,128.5,127.7,127.2,126.7,124.0,118.0,114.4,113.6,84.8$, $84.7,83.2,76.1,75.2,72.8,63.2$, and 55.5 .

HRMS (APCl) $m / z:\left[\mathrm{M}+\mathrm{H}^{+}-\mathrm{H}_{2} \mathrm{O}\right]^{+}$Calcd for $\mathrm{C}_{24} \mathrm{H}_{15} \mathrm{O}^{+}$requires 319.1123 ; found 319.1112 .

IR (neat): 3386, 3291, 3058, 2215, 1602, 1509, 1252, 1171, and $1027 \mathrm{~cm}^{-1}$.

mp: $117-118^{\circ} \mathrm{C}$. 


\section{1-(1-((4-Methoxyphenyl)buta-1,3-diyn-1-yl)naphthalen-2-yl)-3-(trimethylsilyl)prop-2-yn-1-one (14)}

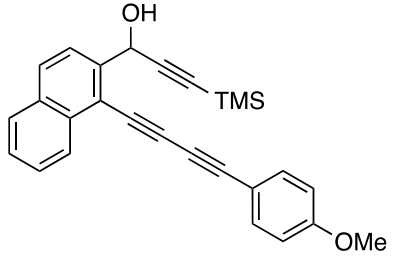

S8

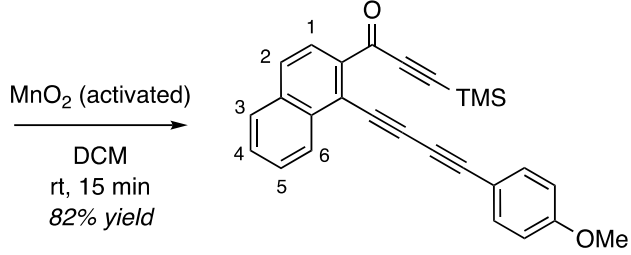

14

General procedure B was followed using the alcohol S8 (196 mg, $0.48 \mathrm{mmol}, 1.0$ equiv) and activated $\mathrm{MnO}_{2}$ powder (413 mg, 4.80 mmol, 10.0 equiv) to prepare the ynone 14. This procedure yielded 14 (160 mg, $0.39 \mathrm{mmol}, 82 \%)$ as a dark brown viscous oil.

\section{Data for ynone 14:}

${ }^{1} \mathrm{H}$ NMR $\left(500 \mathrm{MHz}, \mathrm{CDCl}_{3}\right.$ ): $\delta 8.59$ (nfom, $\left.1 \mathrm{H}, H 6\right), 8.09$ (d, $\left.J=8.7 \mathrm{~Hz}, 1 \mathrm{H}, H 1\right), 7.89$ (dd, $\left.J=8.7,1.1 \mathrm{~Hz}, 1 \mathrm{H}, H 2\right), 7.88$ (nfom, $1 \mathrm{H}$, $H 3$ ), 7.68 (ddd, $J=8.3,6.8,1.6 \mathrm{~Hz}, 1 \mathrm{H}, H 4), 7.64$ (ddd, $J=8.2,6.9,1.4 \mathrm{~Hz}, 1 \mathrm{H}, H 5), 7.53$ [nfod, Japp $=9.0 \mathrm{~Hz}, 2 \mathrm{H},(m-\mathrm{OMe}) \mathrm{PhH}$ ], 6.89 [nfod, Japp $=8.9 \mathrm{~Hz}, 2 \mathrm{H},(\mathrm{o}-\mathrm{OMe}) \mathrm{PhH}$, $3.85\left(\mathrm{~s}, 3 \mathrm{H}, \mathrm{ArOCH}_{3}\right)$, and 0.34 [s, $\left.9 \mathrm{H}, \mathrm{Si}\left(\mathrm{CH}_{3}\right)_{3}\right]$.

${ }^{13} \mathrm{C}$ NMR $\left(125 \mathrm{MHz}, \mathrm{CDCl}_{3}\right): \delta$ 177.4, 160.8, 138.0, 135.0, 134.6, 134.4, 129.1, 129.0, 128.5, 128.2, 128.0, 126.3, 121.2, 114.4, 113.8, $102.4,102.3,87.3,86.0,77.4,73.6,55.5$, and -0.5 .

HRMS (APCl) m/z: [M $\left.+\mathrm{H}_{2} \mathrm{O}+\mathrm{H}^{+}-\mathrm{CH}_{4}\right]^{]^{*}}$ Calcd for $\mathrm{C}_{26} \mathrm{H}_{21} \mathrm{O}_{3} \mathrm{Si}^{+}$requires 409.1254; found 409.1243 .

IR (neat): 2925, 2853, 2193, 1704, 1632, 1509, 1248, and $1172 \mathrm{~cm}^{-1}$.

* We propose the following structure for this ion, observed in the APCI HRMS spectrum:

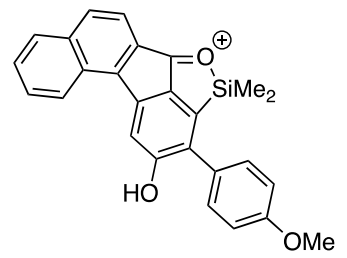




\section{0,10-bis(5-(4-(Trifluoromethyl)phenyl)penta-2,4-diyn-1-yl)anthracen-9(10H)-one (16)}

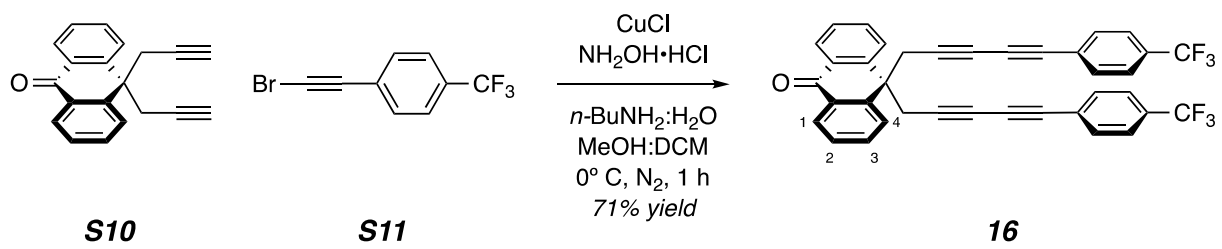

General procedure A was followed using 10,10-di(prop-2-yn-1-yl)anthracen-9(10H)-one ${ }^{11}$ (S10, $270 \mathrm{mg}, 0.97 \mathrm{mmol}, 1.0$ equiv) and 1-(bromoethynyl)-4-(trifluoromethyl)benzene ${ }^{12}(\mathbf{S 1 1}, 533 \mathrm{mg}, 2.14 \mathrm{mmol}, 2.2$ equiv) to prepare the tetrayne 16. Precipitation from $\mathrm{CH}_{2} \mathrm{Cl}_{2}$ by the addition of $\mathrm{MeOH}$ followed by filtration ( 3 iterations) yielded 16 (430 mg, $0.71 \mathrm{mmol}, 71 \%$ ) as an off-white powder.

Data for tetrayne 16:

${ }^{1} \mathrm{H}$ NMR $\left(500 \mathrm{MHz}, \mathrm{CDCl}_{3}\right): \delta 8.45$ (dd, $\left.J=7.9,1.5 \mathrm{~Hz}, 2 \mathrm{H}, H 1\right), 7.77$ (ddd, $\left.J=8.1,6.6,1.6 \mathrm{~Hz}, 2 \mathrm{H}, H 3\right), 7.75$ (dd, $J=8.1,1.8 \mathrm{~Hz}$, $2 \mathrm{H}, H 4), 7.58$ (ddd, $J=8.1,6.6,1.7 \mathrm{~Hz}, 2 \mathrm{H}, H 2), 7.52$ [nfod, $J_{a p p}=8.5 \mathrm{~Hz}, 4 \mathrm{H}, m-\mathrm{PhH}\left(\mathrm{CF}_{3}\right)$ ], 7.47 [nfod, Japp $=8.5 \mathrm{~Hz}, 4 \mathrm{H}, o-\mathrm{PhH}\left(\mathrm{CF}_{3}\right)$ ], and $3.31\left[\mathrm{~s}, 4 \mathrm{H},\left(\mathrm{Ar}_{2} \mathrm{C}\left(\mathrm{CH}_{2} \mathrm{CCAr}\right)_{2}\right]\right.$.

${ }^{13} \mathrm{C} \mathrm{NMR}\left(125 \mathrm{MHz}, \mathrm{CDCl}_{3}\right): \delta 183.3,144.0,134.0,132.9$ ( $m$ to the $\mathrm{CF}_{3}$, but coupling not observed), 132.3, $130.8(\mathrm{q}, \mathrm{J}=32.7, \mathrm{~Hz}$ $C_{\text {ipso }}-\mathrm{CF}_{3}$ ), 128.3, 128.2, 125.9, 125.5 (q, $\left.J=1.4 \mathrm{~Hz}, p-C_{\mathrm{Ar}} \mathrm{CF}_{3}\right), 125.4$ (q, $\left.J=3.9 \mathrm{~Hz}, C=\mathrm{CCF}_{3}\right), 123.8$ (q, $\left.J=272.1 \mathrm{~Hz}, C F_{3}\right), 80.5$, $76.0,74.4,68.0,45.5$, and 34.7 .

${ }^{19} \mathrm{~F}$ NMR $\left(471 \mathrm{MHz}, \mathrm{CDCl}_{3}\right): \delta-62.93$.

HRMS (ESI-TOF) $\mathrm{m} / \mathrm{z}:\left[\mathrm{M}+\mathrm{H}^{+}\right]$Calcd for $\mathrm{C}_{38} \mathrm{H}_{21} \mathrm{~F}_{6} \mathrm{O}^{+}$requires 607.1497; found 607.1470.

IR (neat): $3071,2932,1666,1601,1320,1167,1126$, and $1064 \mathrm{~cm}^{-1}$.

mp: $323-325^{\circ} \mathrm{C}$ (decomposition). 


\section{6,13-Dimethyl-7,14-bis(trimethylsilyl)difluoreno[3,4-b:3',4'-d]furan-8,15-dione (9-S)}

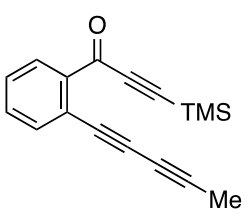

7<smiles>COc1ccc(S(=O)c2ccc(OC)cc2)cc1</smiles>

2d
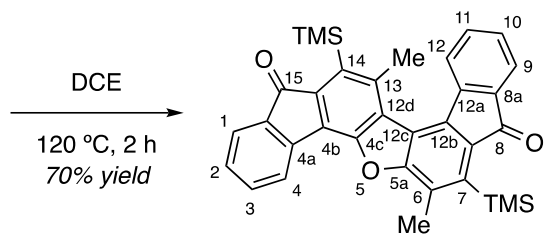

9-S

General procedure C was followed using the triynone $7(58 \mathrm{mg}, 0.22 \mathrm{mmol}, 2.2$ equiv) and 4,4'-sulfinylbis(methoxybenzene) (2d, $26 \mathrm{mg}, 0.10 \mathrm{mmol}, 1.0$ equiv) to prepare the difluorenofuran 9-S. Upon cooling to room temperature, the product precipitated from solution and was collected by filtration. Further precipitation by adding $\mathrm{MeOH}$ to the filtrate yielded additional $\mathbf{9 - S}$ (38 $\mathrm{mg}$ in total, $0.07 \mathrm{mmol}, 70 \%$ ) as a bright yellow crystalline solid.

The same reaction, performed instead in benzene- $d_{6}$ solution, afforded 9-S in a $55 \%$ yield along with a minor amount of the [4+2] benzyne/benzene- $d_{6}$ adduct $(5: 1$ ratio by ${ }^{1} \mathrm{H}$ NMR). The structure of this benzene DA adduct was inferred based on its similar NMR characteristics to those of the related triyne in which the methyl group in 7 was, instead, a 3-acetoxypropyl group. ${ }^{13}$ In addition, the GC/MS data (El, $70 \mathrm{eV}$ ) showed a molecular ion at 348 amu for $\mathrm{C}_{23} \mathrm{H}_{16} \mathrm{D}_{6} \mathrm{OSi}$.

General procedure $\mathrm{C}$ was repeated on a $1.0 \mathrm{mmol}$ scale using the aforementioned reagents. This afforded the desired compound $\mathbf{9 - S}$ in a $57 \%$ yield (312 mg, 0.57 $\mathrm{mmol}$ ) by precipitation from the crude reaction mixture using $\mathrm{MeOH}$. The photos to the right show this sample without vs. with external irradiation with a longwavelength (ca. $365 \mathrm{~nm}$ ) UV lamp.
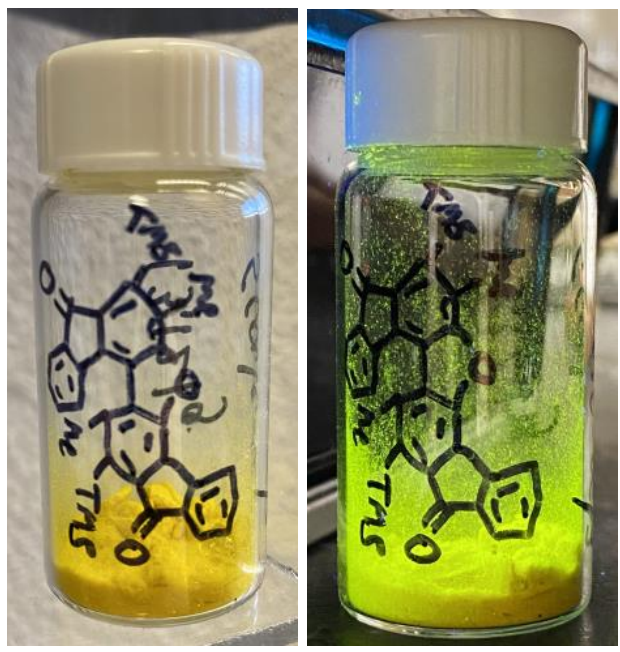

\section{Data for difluorenofuran 9-S:}

${ }^{1} \mathrm{H}$ NMR (500 MHz, CDCl$)$ ): $\delta 7.88$ (ddd, J=7.4, 0.9, $\left.0.9 \mathrm{~Hz}, 1 \mathrm{H}, H 4\right), 7.65$ (ddd, J= 7.3, 1.3, 0.8 Hz, 1H, H1), 7.64 (ddd, J= 7.3, 0.9, $0.9 \mathrm{~Hz}, 1 \mathrm{H}, H 9$ ), 7.55 (ddd, J=7.5, 7.5, $1.2 \mathrm{~Hz}, 1 \mathrm{H}, H 3$ ), 7.52 (ddd, J=7.5, 7.5, $1.2 \mathrm{~Hz}, 1 \mathrm{H}, H 11$ ), 7.37 (ddd, J=7.5, 0.9, 0.9 Hz, $1 \mathrm{H}$, H12), 7.312 (ddd, $J=7.4,7.4,1.0 \mathrm{~Hz}, 1 \mathrm{H}, \mathrm{H10}$ ), 7.306 (ddd, $J=7.5,7.5,1.0 \mathrm{~Hz}, 1 \mathrm{H}, \mathrm{H} 2), 2.76(\mathrm{~s}, 3 \mathrm{H}, \mathrm{C} 6 \mathrm{CH}), 2.71(\mathrm{~s}, 3 \mathrm{H}, \mathrm{C} 13 \mathrm{CH}$ ), $0.54\left[\mathrm{~s}, 9 \mathrm{H}, \mathrm{C} 14 \mathrm{Si}\left(\mathrm{CH}_{3}\right)_{3}\right]$, and $0.52\left[\mathrm{~s}, 9 \mathrm{H}, \mathrm{C} 7 \mathrm{Si}\left(\mathrm{CH}_{3}\right)_{3}\right]^{*}$ *

*The exact values of the observed chemical shifts varied with concentration of the NMR samples, suggesting that aggregation impacts the behavior of this compound in $\mathrm{CDCl}_{3}$. This was not systematically studied.

${ }^{13} \mathrm{C}$ NMR (125 MHz, $\left.\mathrm{CDCl}_{3}\right): \delta 194.7,194.3,160.8(\mathrm{C} 5 \mathrm{a}), 151.8,(\mathrm{C} 4 \mathrm{c}), 144.2(\mathrm{C} 12 \mathrm{a}), 141.8(\mathrm{C} 7$ or $\mathrm{C} 12 \mathrm{~d})$, $141.7(\mathrm{C} 7 \mathrm{or} \mathrm{C} 12 \mathrm{~d})$, 141.4(C4a), 140.01, 140.00(C12b), 137.7(C14), 136.5, 134.9(C3), 134.4(C15a), 134.0(C8a), 133.5(C11), 130.4(C13), 129.0(C2 or C10), 128.8(C2 or C10), 127.8(C6), 125.6(C4b), 124.9(C12), 124.2(C1 or C9), 123.9(C1 or C9), 123.1(C4), 118.9, 27.3(C13CH3), $16.5\left(\mathrm{C}_{6} \mathrm{CH}_{3}\right), 2.9$, and 2.8 .

can't identify C14a, C12c, C7a, or assign 140.01, 136.5, 118.9.

HRMS (ESI-TOF) $m / z$ : $\left[\mathrm{M}+\mathrm{H}^{+}-\mathrm{CH}_{4}\right]^{+}$Calcd for $\mathrm{C}_{33} \mathrm{H}_{29} \mathrm{O}_{3} \mathrm{Si}_{2}{ }^{+}$requires 529.1655; found 529.1635.

IR (neat): 2978, 2948, 2898, 1712, 1606, 1283, and $1247 \mathrm{~cm}^{-1}$.

mp: $292-293^{\circ} \mathrm{C}$. 


\section{2-Methyl-3-phenoxy-4-(phenylthio)-1-(trimethylsilyl)-9H-fluoren-9-one (8),}

6,13-Dimethyl-7,14-bis(trimethylsilyl)difluoreno[3,4-b:3',4'-d]furan-8,15-dione (9-S), and

[3,5-Dimethyl-2,6-bis(trimethylsilyl)difluoreno[3,4-b:4',3'-d]furan-1,7-dione (9-U) or

\section{7,8-Dimethyl-6,9-bis(trimethylsilyl)difluoreno[4,3-b:3',4'-d]furan-5,10-dione (9-U')]}

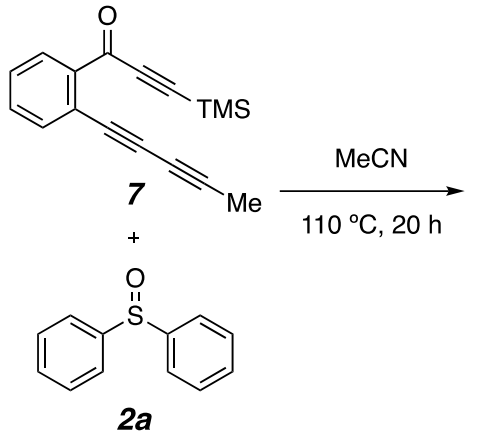

$2 a$

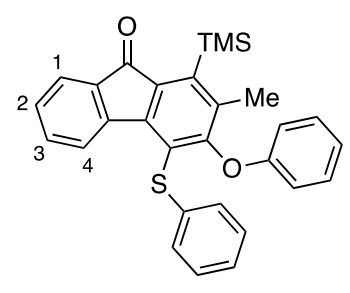

$8,63 \%$

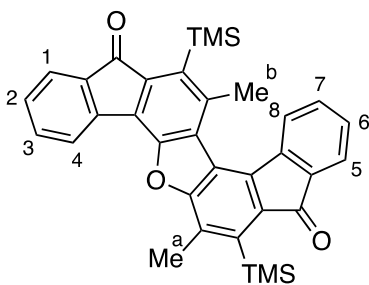

9-S, $27 \%$

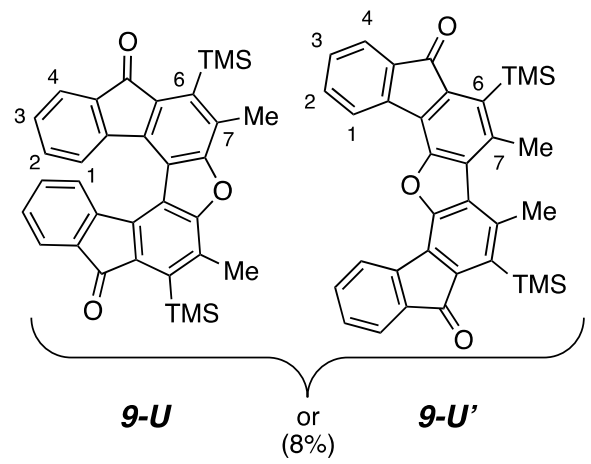

General procedure $\mathrm{C}$ was followed (except that acetonitrile was the reaction solvent rather than 1,2-dichloroethane) using the triynone 7 (40 mg, $0.15 \mathrm{mmol}, 3.0$ equiv) and sulfinyldibenzene (2a, $10 \mathrm{mg}, 0.05 \mathrm{mmol}, 1.0$ equiv) to produce compounds $\mathbf{8}$, 9-S, and 9-U/9U'. The reaction mixture was concentrated and purified by MPLC (49:1 hexanes/EtOAc) to afford 8 (15 mg, $0.03 \mathrm{mmol}, 63 \%)$ as a yellow oil followed by $9-\mathbf{S}(7 \mathrm{mg}, 0.014 \mathrm{mmol}, 27 \%)+9-\mathbf{U}(2 \mathrm{mg}, 0.004 \mathrm{mmol}, 8 \%)$ as an inseparable mixture of the two isomers. Isomer 9-S was crystalized from this mixture using vapor diffusion (DCM/pentanes) to provide a pure sample of $\mathbf{9 - S}$, the ${ }^{1} \mathrm{H}$ NMR spectral data of which was essentially identical with those from the same compound prepared using $\mathbf{2 d}$ (preceding procedure).

\section{Data for fluorenone 8:}

${ }^{1} \mathrm{H}$ NMR $\left(500 \mathrm{MHz}, \mathrm{CDCl}_{3}\right.$ ): $\delta 8.43$ (ddd, $\left.J=7.7,0.8,0.8 \mathrm{~Hz}, 1 \mathrm{H}, H 4\right), 7.62$ (ddd, J= 7.2, 1.3, 0.8 Hz, 1H, H1), 7.38 (ddd, J=7.5, 7.5, $1.3 \mathrm{~Hz}, 1 \mathrm{H}, H 3$ ), 7.27 (ddd, $J=7.4,7.4,1.0 \mathrm{~Hz}, 1 \mathrm{H}, H 2), 7.22$ (d of nfod $J=7.4$ and $J_{\text {app }}=8.8 \mathrm{~Hz}, 2 \mathrm{H}, \mathrm{OPh}$ meta), $7.18(\mathrm{nfom}, 2 \mathrm{H}$, $\mathrm{SPh}_{\text {meta }}$ ), 7.114 (nfod, Japp $=8.0 \mathrm{~Hz}, 2 \mathrm{H}, \mathrm{SPh}$ ortho), 7.106 (overlapped m, 1H, SPh $\mathrm{Sara}_{\text {) }}, 6.97$, (tt, J=7.4, 1.2 Hz, 1H, OPh para), 6.67 (nfod, Japp $\left.=8.8 \mathrm{~Hz}, 2 \mathrm{H}, \mathrm{OPh}_{\text {ortho }}\right), 2.25\left(\mathrm{~s}, 3 \mathrm{H}, \mathrm{ArCH}_{3}\right)$, and $0.46\left[\mathrm{~s}, 9 \mathrm{H}, \mathrm{Si}\left(\mathrm{CH}_{3}\right)_{3}\right]$.

${ }^{13} \mathrm{C}$ NMR (125 MHz, $\mathrm{CDCl}_{3}$ ): $\delta$ 194.2(C9), 158.2(C6, HMBC), 157.6(OPhipso), 147.8(C4b), 146.0(C8, HMBC), 143.6(C4a, HMBC), 139.7(C7, HMBC), 138.2(C5, by default), 136.1(SPh ${ }_{\text {ipso, }}$ HMBC), 134.8(C3, HSQC), 134.5(C9a), 129.7(OPh meta, HSQC), 129.2(C2,

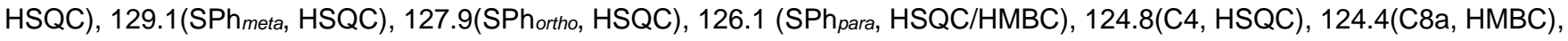
123.7(C1, HSQC/HMBC), 122.0(OPh para, HSQC), 114.9(OPhortho, HSQC), 18.4, and 2.9.

HRMS (ESI-TOF) $\mathrm{m} / \mathrm{z}$ : $\left[\mathrm{M}+\mathrm{H}^{+}-\mathrm{CH}_{4}\right]^{+}$Calcd for $\mathrm{C}_{28} \mathrm{H}_{23} \mathrm{O}_{2} \mathrm{SSi}^{+}$requires 451.1188; found 451.1173.

IR (neat): $3072,2950,1713,1599,1489,1337$, and $1210 \mathrm{~cm}^{-1}$.

Data suggesting the presence of the difluorenofuran 9-U or 9-U' for this minor component in the mixture with 9-S:

${ }^{1} \mathrm{H}$ NMR $\left(500 \mathrm{MHz}, \mathrm{CDCl}_{3}\right.$ ): $\delta 7.64$ (ddd, $\left.J=7.4,1.3,0.8 \mathrm{~Hz}, 1 \mathrm{H}_{\text {rel }}, H 4\right), 7.23$ (ddd, J= 7.4, 7.4, $1.1 \mathrm{~Hz}, 1 \mathrm{H}_{\text {rel }}, H 2$ or $\left.H 3 i\right), 7.15$ (ddd, $J=7.4,7.4,1.3 \mathrm{~Hz}, 1 \mathrm{H}_{\text {rel }}, \mathrm{H} 2$ or $\left.H 3 i\right), 7.10$ (br d, $\left.J=7.4 \mathrm{~Hz}, 1 \mathrm{H}_{\text {rel }}, H 4\right), 2.72\left(\mathrm{~s}, 3 \mathrm{H}_{\text {rel }}, \mathrm{ArCH}_{3}\right.$, and $0.53\left(\mathrm{~s}, 9 \mathrm{H}_{\mathrm{rel}}, \mathrm{Si}\left(\mathrm{CH}_{3}\right) 3\right]$.

HRMS (ESI-TOF) $\mathrm{m} / \mathrm{z}$ : Calcd for $\mathrm{C}_{33} \mathrm{H}_{29} \mathrm{O}_{3} \mathrm{Si}_{2}{ }^{+}\left[\mathrm{M}-\mathrm{CH}_{3}\right]^{+}$requires 529.1655; found 529.1648 (recorded for the mixture containing both 9-S and 9-U). Notably, no ions suggestive of a phenoxathiine structure were observed for the HRMS. 


\section{6,13-bis(4-Methoxyphenyl)-7,14-bis(trimethylsilyl)difluoreno[3,4-b:3',4'-d]furan-8,15-dione (11-S)}

and

\section{7,8-bis(4-Methoxyphenyl)-6,9-bis(trimethylsilyl)difluoreno[4,3-b:3',4'-d]furan-5,10-dione (11-U)}

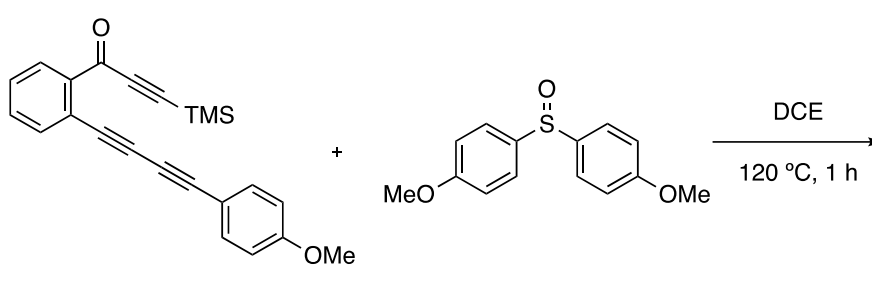

10

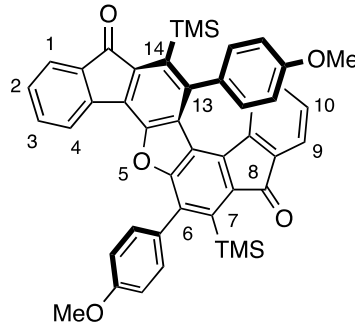

$11-S$

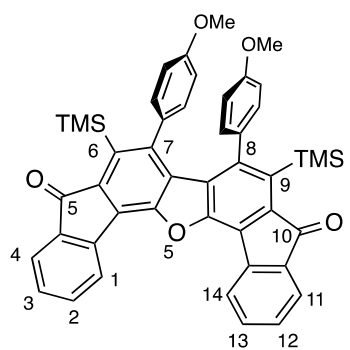

11-U

General procedure $\mathrm{C}$ was followed using the triynone 10 (133 $\mathrm{mg}, 0.37 \mathrm{mmol}, 2.2$ equiv) and 4,4'-sulfinylbis(methoxybenzene) (2d, $45 \mathrm{mg}, 0.17 \mathrm{mmol}, 1.0$ equiv) to prepare the difluorenofurans 11-S and 11-U (1.0:1.1). Purification by MPLC (19:1 hexanes:EtOAc) yielded the faster eluting compound 11-S (42 $\mathrm{mg}, 0.058 \mathrm{mmol}, 34 \%)$ as a dark yellow crystalline solid followed by 11-U (48 mg, 0.066 $\mathrm{mmol}, 39 \%)$ as an orange crystalline solid.

\section{Data for difluorenofuran 11-S:}

${ }^{1} \mathrm{H}$ NMR $\left(500 \mathrm{MHz}, \mathrm{CDCl}_{3}\right): \delta 7.65$ (ddd, $\left.J=7.3,1.0,0.8 \mathrm{~Hz}, 1 \mathrm{H}, H 1\right), 7.52$ (ddd, $\left.J=7.4,0.9,0.8 \mathrm{~Hz}, 1 \mathrm{H}, H 4\right), 7.48$ [nfod Japp $=8.7$ $\mathrm{Hz}, 2 \mathrm{H}, \mathrm{C} 13(\mathrm{~m}-\mathrm{OMe}) \mathrm{PhH}$ ], 7.48-7.44 (m, 2H, $\mathrm{H3}$ and $H 9), 7.44$ [nfod $J_{a p p}=8.7 \mathrm{~Hz}, 2 \mathrm{H}, \mathrm{C} 6(\mathrm{~m}$-OMe) PhH], 7.30 (ddd, $J=7.4,7.4,1.1$ $\mathrm{Hz}, 1 \mathrm{H}, H 2$ ), 7.09 [nfod Japp $=8.7 \mathrm{~Hz}, 2 \mathrm{H}, \mathrm{C} 6(0-\mathrm{OMe}) \mathrm{PhH}$ ], 7.00 (ddd, $J=7.5,7.5,0.8 \mathrm{~Hz}, 1 \mathrm{H}, H 10$ ), 6.82 [nfod Japp $=8.6 \mathrm{~Hz}, 2 \mathrm{H}$, C13(o-OMe)PhH], 6.80 (ddd, $J=7.5,7.5,1.3 \mathrm{~Hz}, 1 \mathrm{H}, H 11$ ), 6.20 (ddd, $J=7.5,0.9,0.6 \mathrm{~Hz}, 1 \mathrm{H}, H 12$ ), 3.97 (s, 3H, C6PhOCH3), 3.69 $(\mathrm{s}, 3 \mathrm{H}, \mathrm{C} 13 \mathrm{PhOCH}), 0.11$ [s, 9H, $\left.\mathrm{Si}\left(\mathrm{CH}_{3}\right) 3\right]$, and 0.03 [s, 9H, Si $\left.\left(\mathrm{CH}_{3}\right)_{3}{ }^{\prime}\right]$.

${ }^{13} \mathrm{C} \mathrm{NMR}^{\star} \delta$ 195.1(C15), 194.3(C8), 160.4 [C13(PhCipso-ome], 159.5 [C6(PhCipso-ome)], 143.7(C12a), 141.9(C12b), 141.1(C14 or C7), 140.8(C4a), 137.2(C14 or C7), 134.8[C13(Cipso-Ar)], 134.7(C3), 133.8(C15a), 132.8(C11), 132.5(C8a), 131.8[C6(PhC

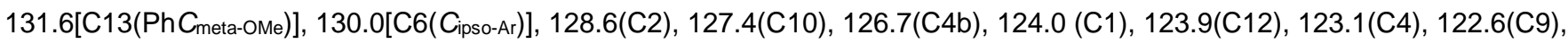

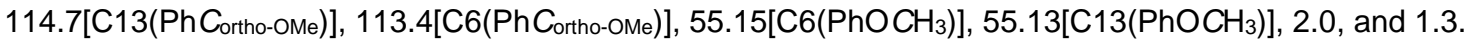

*Limited solubility prevented collection of quality $1 \mathrm{D}{ }^{13} \mathrm{C}$ NMR data. The values and assignments here come from exhaustive analysis of the HSQC and HMBC data.

HRMS (APCl) $m / z:\left[\mathrm{M}+\mathrm{H}^{+}-\mathrm{CH}_{4}\right]^{+}$Calcd for $\mathrm{C}_{45} \mathrm{H}_{37} \mathrm{O}_{5} \mathrm{Si}_{2}{ }^{+}$requires 713.2180; found 713.2165.

IR (neat): 2952, 2899, 2837, 1710, 1606, 1513, 1248, and $1135 \mathrm{~cm}^{-1}$.

$\mathrm{mp}: 329-331^{\circ} \mathrm{C}$.

\section{Data for difluorenofuran 11-U:}

${ }^{1} \mathrm{H}$ NMR $\left(500 \mathrm{MHz}, \mathrm{CDCl}_{3}\right.$ ): $\delta 8.05$ (ddd, $\left.J=7.3,0.8,0.8 \mathrm{~Hz}, 2 \mathrm{H}, H 4\right), 7.70$ (ddd, $J=7.3,1.0,0.8 \mathrm{~Hz}, 2 \mathrm{H}, H 1$ ), 7.67 (ddd, $J=7.7,7.4$, $1.1 \mathrm{~Hz}, 2 \mathrm{H}, H 3), 7.39$ (ddd, $J=7.5,7.4,1.0 \mathrm{~Hz}, 2 \mathrm{H}, \mathrm{H} 2), 6.65$ [nfod, Japp $=8.6 \mathrm{~Hz}, 4 \mathrm{H},(m-\mathrm{OMe}) \mathrm{PhH}$ ], 6.49 [nfod, Japp $=8.6 \mathrm{~Hz}, 4 \mathrm{H}$, (o-OMe) $\mathrm{PhH}$ ], $3.87\left(\mathrm{~s}, 6 \mathrm{H}, \mathrm{OCH}_{3}\right)$, and $-0.17\left[\mathrm{~s}, 18 \mathrm{H}, \mathrm{Si}\left(\mathrm{CH}_{3}\right)_{3}\right]$.

${ }^{13} \mathrm{C}$ NMR $\left(126 \mathrm{MHz}, \mathrm{CDCl}_{3}\right): \delta 195.2,159.2,152.8,147.0,142.2,141.2,138.0,134.9(2 x), 134.2,132.0,129.1,128.3,126.9,124.4$, 123.0, 113.9, 55.3, and 2.0.

HRMS (APCI) $m / z:\left[\mathrm{M}+\mathrm{H}^{+}-\mathrm{CH}_{4}\right]^{+}$Calcd for $\mathrm{C}_{45} \mathrm{H}_{37} \mathrm{O}_{5} \mathrm{Si}_{2}{ }^{+}$requires 713.2180; found 713.2160. 
IR (neat): 2952, 2925, 2854, 1710, 1606, 1513, 1248, and $1132 \mathrm{~cm}^{-1}$. $m p: 318-320^{\circ} \mathrm{C}$. 


\section{8,17-Dimethyl-9,18-bis(trimethylsilyl)benzo[5,6]fluoreno[3,4-b]benzo[5,6]fluoreno[3,4-d]furan-10,19-dione (13-}

S)

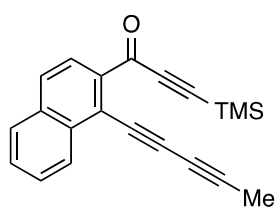

12

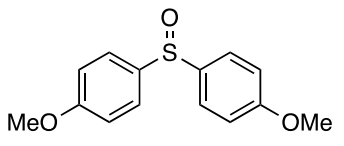

$2 d$
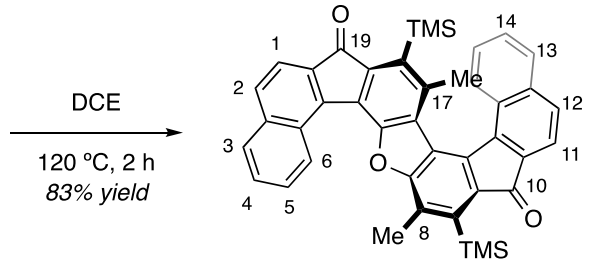

13-S

General procedure C was followed using triyne 12 (91 mg, $0.28 \mathrm{mmol}, 2.2$ equiv) and 4,4'-sulfinylbis(methoxybenzene) (2d, 23 mg, $0.12 \mathrm{mmol}, 1.0$ equiv) to provide the difluorenofuran 13-S. Upon cooling to room temperature, the product had precipitated from solution and was collected by filtration. Further precipitation from the filtrate by the addition of $\mathrm{MeOH}$ and collection of that solid yielded 13-S (71 $\mathrm{mg}$ in total, $0.11 \mathrm{mmol}, 83 \%)$ as a burgundy red crystalline solid.

\section{Data for difluorenofuran 13-S:}

${ }^{1} \mathrm{H}$ NMR $\left(500 \mathrm{MHz}, \mathrm{CDCl}_{3}\right)$ : $\delta 9.63$ (dd, $\left.J=8.7,0.9 \mathrm{~Hz}, 1 \mathrm{H}, H 6\right), 7.93$ (dddd, $\left.J=0.9,0.9,0.9,8.5 \mathrm{~Hz}, 1 \mathrm{H}, H 16\right), 7.89$ (br d, J = 8.5 $\mathrm{Hz}, 1 \mathrm{H}, H 3$ or $H 13$ ), 7.843 (br d, $J=8.5 \mathrm{~Hz}, 1 \mathrm{H}, H 13$ or $H 3$ ), 7.837 (br d, J=8.1 Hz, $1 \mathrm{H}, H 12$ or $H 2$ ), $7.774(\mathrm{~d}, J=8.1 \mathrm{~Hz}, 1 \mathrm{H}, H 11$ or $H 1$ ), 7.772 (br d, J = 8.1 Hz, $1 \mathrm{H}, H 2$ or $H 12), 7.73(\mathrm{~d}, J=8.1 \mathrm{~Hz}, 1 \mathrm{H}, H 1$ or $H 11), 7.67$ (ddd, J=1.5, 6.8, 8.7 Hz, $1 \mathrm{H}, H 4), 7.56(\mathrm{ddd}$, $J=1.2,6.7,8.5 \mathrm{~Hz}, 1 \mathrm{H}, H 14$ or $H 5), 7.55$ (ddd, $J=1.2,6.7,8.5 \mathrm{~Hz}, 1 \mathrm{H}, H 5$ or $H 14$ ), 7.33 (ddd, $J=1.3,6.8,8.5 \mathrm{~Hz}, 1 \mathrm{H}, H 15$ ), 2.87

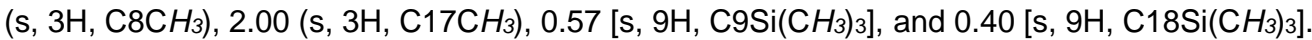

${ }^{13} \mathrm{C}$ NMR $\left(126 \mathrm{MHz}, \mathrm{CDCl}_{3}\right): \delta$ 195.2, 194.3, 159.8, 150.6, 146.1, 144.2, 142.7, 141.8, 141.2, 141.0, 138.5, 138.4, 138.0, 137.7, 132.2, 132.0, 131.6, 130.1, 130.0, 129.42, 129.41, 129.1, 128.4, 128.3, 128.2, 128.0, 127.1, 126.3, 126.1, 126.0, 125.2, 120.6, 120.1, 119.9, $26.2,16.8,3.0$, and 2.7 .

HRMS (ESI-TOF) m/z: [M] ${ }^{+}$Calcd for $\mathrm{C}_{42} \mathrm{H}_{36} \mathrm{O}_{3} \mathrm{Si}_{2}{ }^{+}$requires 644.2203; found 644.2182.

IR (neat): $3053,2945,2897,1707,1246$, and $1040 \mathrm{~cm}^{-1}$.

mp: $197-199^{\circ} \mathrm{C}$ (sublimation). 


\section{( \pm )-8,17-bis(4-Methoxyphenyl)-9,18-bis(trimethylsilyl)benzo[5,6]fluoreno[3,4-b]benzo[5,6]fluoreno[3,4- $d]$ furan-}

\section{0,19-dione (15-S)}

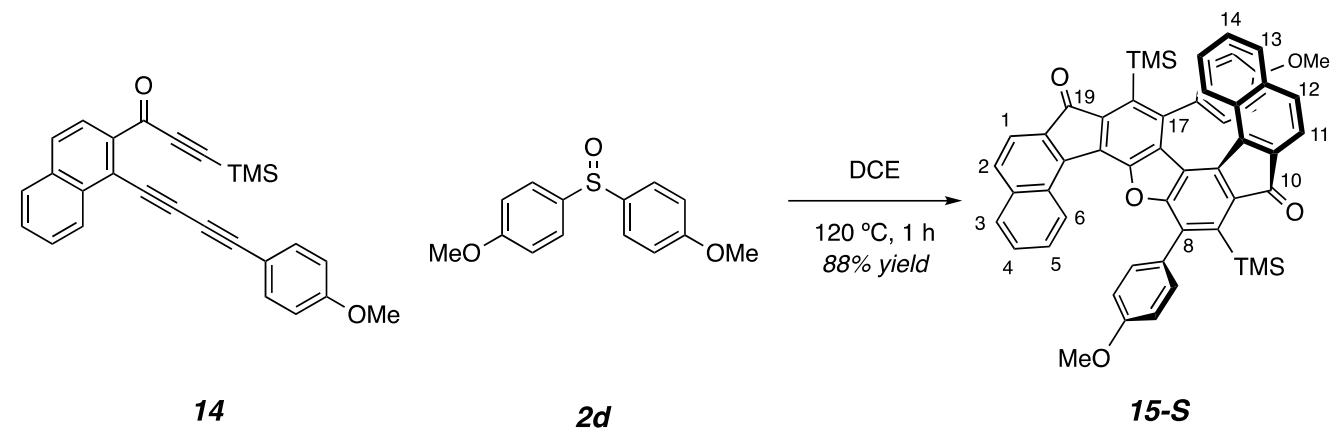

General procedure C was followed using triyne 14 (150 mg, $0.37 \mathrm{mmol}, 2.2$ equiv) and 4,4'-sulfinylbis(methoxybenzene) (2d, $44 \mathrm{mg}$, $0.17 \mathrm{mmol}, 1.0$ equiv) to prepare difluorenofuran 15-S. Precipitation from DCM using MeOH yielded 15-S (124 mg, $0.15 \mathrm{mmol}, 88 \%$ ) as a bright red crystalline solid.

\section{Data for S-shaped difluorenofuran 15-S:}

${ }^{1} \mathrm{H}$ NMR (500 MHz, CDCl 3 ): $\delta 9.03$ (dddd, $\left.J=8.6,0.9,0.9,0.7 \mathrm{~Hz}, 1 \mathrm{H}, H 6\right), 7.83$ (ddd, J= 8.3, 0.6, 0.6 Hz, $\left.1 \mathrm{H}, H 3\right), 7.80$ (dd, J= 7.9, $0.6 \mathrm{~Hz}, 1 \mathrm{H}, H 1$ or $H 2), 7.75$ (d, $J=8.1 \mathrm{~Hz}, 1 \mathrm{H}, H 1$ or $H 2), 7.66$ (dddd, $J=8.3,0.8,0.8,0.3 \mathrm{~Hz}, 1 \mathrm{H}, H 13), 7.60(\mathrm{~d}, J=8.1 \mathrm{~Hz}, 1 \mathrm{H}, H 11$ or H12), 7.58 (d, $J=8.3 \mathrm{~Hz}, 1 \mathrm{H}, H 11$ or $H 12), 7.56$ (br d, $J=7.6 \mathrm{~Hz}, 1 \mathrm{H}, \mathrm{PhH}(\mathrm{OMe})$ ), ${ }^{*} 7.55$ (dddd, $\left.J=8.4,0.6,0.6,0.6 \mathrm{~Hz}, 1 \mathrm{H}, H 16\right)$, 7.52 (ddd, $J=8.0,6.8,1.1 \mathrm{~Hz}, 1 \mathrm{H}, \mathrm{H} 4$ or H5), 7.42 (br d, $J=7.9 \mathrm{~Hz}, 1 \mathrm{H}, \mathrm{PhH}(\mathrm{OMe})$ ), ${ }^{*} 7.39$ (ddd, $\left.J=8.1,6.8,1.2 \mathrm{~Hz}, 1 \mathrm{H}, H 4 \mathrm{or} H 5\right)$, 7.19 (br d, $J=8.3 \mathrm{~Hz}, 1 \mathrm{H}, \mathrm{PhH}(\mathrm{OMe})$ ), ${ }^{*} 7.16$ (br d, $J=8.3 \mathrm{~Hz}, 1 \mathrm{H}, \mathrm{PhH}(\mathrm{OMe})$ ), ${ }^{*} 7.14$ (ddd, $\left.J=8.3,6.7,1.3 \mathrm{~Hz}, 1 \mathrm{H}, H 14\right), 7.10$ (ddd, $J=8.2,6.8,1.2 \mathrm{~Hz}, 1 \mathrm{H}, H 15), 7.09$ (br d, $J=8.3 \mathrm{~Hz}, 1 \mathrm{H}, \mathrm{PhH}(\mathrm{OMe})$ ), ${ }^{6} 6.59$ (br d, $\left.J=7.5 \mathrm{~Hz}, 1 \mathrm{H}, \mathrm{PhH}(\mathrm{OMe})\right)$, 6.09 (br d, $J=7.9 \mathrm{~Hz}$, $1 \mathrm{H}, \mathrm{PhH}(\mathrm{OMe})),{ }^{*} 5.93(\mathrm{br} \mathrm{d}, J=7.5 \mathrm{~Hz}, 1 \mathrm{H}, \mathrm{PhH}(\mathrm{OMe})),{ }^{*} 4.02\left(\mathrm{~s}, 3 \mathrm{H}, \mathrm{C} 8 \mathrm{ArOCH} \mathrm{H}_{3}\right), 3.56(\mathrm{~s}, 3 \mathrm{H}, \mathrm{C} 17 \mathrm{ArOCH}), 0.12[\mathrm{~s}, 9 \mathrm{H}, \mathrm{C} 9 \mathrm{Si}(\mathrm{CH}) 3]$, and $-0.08\left[\mathrm{~s}, 9 \mathrm{H}, \mathrm{C} 18 \mathrm{Si}\left(\mathrm{CH}_{3}\right)_{3}\right]$.

*All eight protons in the two PMP groups showed distinct chemical shifts; each was a broad doublet; this indicates slow (on the NMR timescale) rotation about each of the biaryl bonds.

${ }^{13} \mathrm{C}$ NMR $\left(126 \mathrm{MHz}, \mathrm{CDCl}_{3}\right): \delta 196.1,194.1,159.8,158.8,158.7,151.2,147.4,147.1,144.0,143.8,142.4,140.2,139.4,138.6$, 138.0, 137.4, 134.6, 132.1, 132.08, 132.03, 131.8, 131.7, 131.3, 130.34, 130.32, 129.5, 129.4, 129.32, 129.27, 128.6, 128.4, 128.3, 128.2, 128.0, 127.8, 127.6, 126.8, 126.6, 125.7, 120.6, 119.8, 119.4, 114.2, 114.0, 112.5, 111.5, 55.6, 55.1, 2.4, and 1.7.

HRMS (APCl) $m / z:\left[\mathrm{M}+\mathrm{H}^{+}-\mathrm{CH}_{4}\right]^{+}$Calcd for $\mathrm{C}_{53} \mathrm{H}_{41} \mathrm{O}_{5} \mathrm{Si}_{2}{ }^{+}$requires 813.2493; found 813.2467.

IR (neat): 3051, 2996, 2951, 2897, 2835, 1704, 1511, 1246, and $1173 \mathrm{~cm}^{-1}$.

mp: $343-345^{\circ} \mathrm{C}$. 


\section{5',11'-bis(4-(Trifluoromethyl)phenyl)-4',10'-bis((4-(trifluoromethyl)phenyl)ethynyl)-1',3',7',9'-tetrahydro-}

\section{H,10"H-dispiro[anthracene-9,2'-diindeno[4,5-b:4',5'-d]furan-8',9"-anthracene]-10,10"-dione (17-S)}

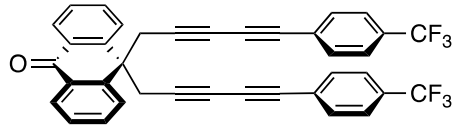

16

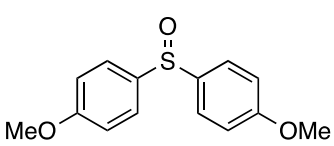

2d

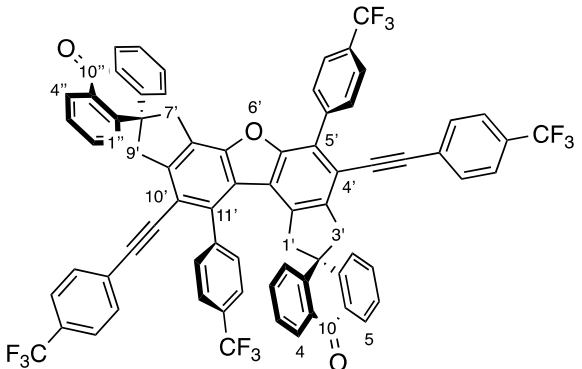

17-S

General procedure C was followed using the anthrone derivative 16 (70 mg, $0.12 \mathrm{mmol}, 2.2$ equiv) and 4,4'sulfinylbis(methoxybenzene) (2d, $15 \mathrm{mg}, 0.06 \mathrm{mmol}, 1.0$ equiv) to prepare the dibenzofuran 17-S. Purification by MPLC (9:1 hexanes:EtOAc) yielded $\mathbf{1 7 - S}(41 \mathrm{mg}, 0.033 \mathrm{mmol}, 55 \%)$ as a yellow crystalline solid.

\section{Data for dibenzofuran 17-S:}

${ }^{1} \mathrm{H}$ NMR $\left(500 \mathrm{MHz}, \mathrm{CDCl}_{3}\right): \delta 8.39$ (dd, $J=8.4,1.6 \mathrm{~Hz}, 2 \mathrm{H}, H 4$ and $H 5$ or $H 4$ "and $H 5$ "), 8.37 (ddd, $J=7.9,1.6 \mathrm{~Hz}, 2 \mathrm{H}, H 4$ and $H 5$ or

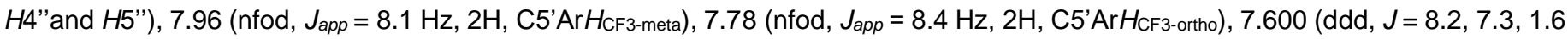
$\mathrm{Hz}, 2 \mathrm{H}, \mathrm{H} 2$ " and $\mathrm{H} 7$ " or $\mathrm{H} 2$ and $\mathrm{H} 7$ ), 7.600 (nfod, $J_{a p p}=8.1 \mathrm{~Hz}, 2 \mathrm{H}, \mathrm{C} 11$ 'ArH $H_{\text {CF3-meta), }} 7.57$ (ddd, $J=8.3,7.0,1.6 \mathrm{~Hz}, 2 \mathrm{H}, \mathrm{H} 2$ " and H7" or H2 and H7), 7.50-7.46 (m, 8H, H1, H8, H3, H6, H1", H8", H3" and H6"), 7.43 (nfod, Japp = 8.4 Hz, 2H, C11'ArHCF3-ortho), 7.39 (nfod,

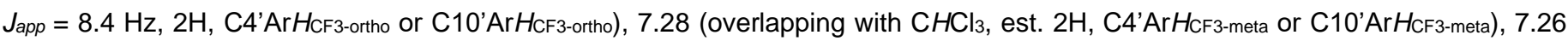
(overlapping with $\mathrm{CHCl}_{3}$, est. 2H, C4'ArHCF3-ortho or C10'ArHCF3-ortho, 7.02 (nfod, Japp $=8.1 \mathrm{~Hz}, 2 \mathrm{H}, \mathrm{C} 4$ 'ArHcF3-meta or C10'ArH $H_{\text {CF3-meta), }}$ ),

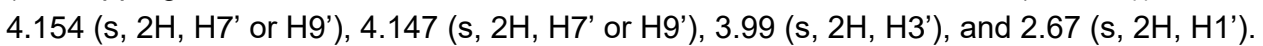

${ }^{13} \mathrm{C}$ NMR $\left(126 \mathrm{MHz}, \mathrm{CDCl}_{3}\right):{ }^{*}$

C-sp': 183.5, 183.4, 154.4, 152.9, 151.4, 151.0, 146.3, 143.5(q, J = 1.1 Hz), 141.8, 138.3, 138.0(q, J = 1.6 Hz), 135.6, 134.6, 134.2, $131.7,131.5,131.4,131.1,130.8(q, J=34.4 \mathrm{~Hz}), 129.7,129.6,127.5,127.4(x 2), 127.3,126.4,126.3(\mathrm{q}, \mathrm{J}=1.5 \mathrm{~Hz}), 125.8,125.5(\mathrm{q}$, $\mathrm{J}=4.0 \mathrm{~Hz}), 125.4(\mathrm{q}, \mathrm{J}=3.2 \mathrm{~Hz}), 125.20(\mathrm{q}, \mathrm{J}=4.6 \mathrm{~Hz}), 125.18,125.0(\mathrm{q}, \mathrm{J}=4.0 \mathrm{~Hz}), 124.9(\mathrm{q}, \mathrm{J}=2.0 \mathrm{~Hz}), 123.0,121.2,116.8,114.1$. C-sp: $96.7\left(\mathrm{CF}_{3} \mathrm{C}_{6} \mathrm{H}_{4} \mathrm{C}\right.$ from $\left.\mathrm{HMBC}\right), 95.8\left(\mathrm{CF}_{3} \mathrm{C}_{6} \mathrm{H}_{4} \mathrm{C}\right.$ from $\left.\mathrm{HMBC}\right)$, 88.8, 88.5.

C-sp" 55.6(C9', HSQC), 54.2(C3', HSQC), 54.0(C1', HSQC), 51.9(C7', HSQC), 47.3 (spiro-C 8/9", HMBC), 46.4 (spiro-C2'/9, HMBC).

\section{correlations in the HSQC spectrum:}

\begin{tabular}{|c|c|c|}
\hline \multicolumn{2}{|c|}{ carbon shift with } & proton shift \\
\hline 134.5 & (C2 or C2") & 7.60 \\
\hline 134.2 & (C2 or C2") & 7.57 \\
\hline 131.3 & (C10'ArC $\left.C_{\mathrm{CF} 3-\mathrm{meta}}\right)$ & 7.28 \\
\hline 130.99 & (C4'ArC $C_{\text {CF3-meta) }}$ & 7.61 \\
\hline 130.99 & (C11'ArC CF3-meta) & 7.02 \\
\hline 130.7 & (C5’ArCCF3-meta) & 7.96 \\
\hline 127.5 & $(C 1 / C 8 / C 3 / C 6 / C 1 " / C 8 " / C 3 " / C 6 ")$ & 7.48 \\
\hline 127.4 & $(\mathrm{x} 2, \mathrm{C} 4 / \mathrm{C} 5 / \mathrm{C} 4 " / \mathrm{C} 5 ")$ & $8.38(2 x)$ \\
\hline 127.2 & (C1/C8/C3/C6/C1"/C8"/C3"/C6") & 7.48 \\
\hline 126.3 & (C1/C8/C3/C6/C1"/C8"/C3"/C6") & 7.48 \\
\hline 125.8 & (C1/C8/C3/C6/C1"/C8"/C3"/C6") & 7.48 \\
\hline 125.5 & (C4'Ar $C_{\text {CF3-ortho) }}$ & 7.25 \\
\hline 125.0 & (C5'ArC CF3-ortho) $^{\prime}$ & 7.79 \\
\hline 124.9 & (C10'ArC $\left.C_{\text {CF3-ortho }}\right)$ & 7.39 \\
\hline & (C11'ArC CF3-ortho & 7.43 \\
\hline
\end{tabular}


* resonances from an unidentified impurity at 48.0 and 80.1 showed no correlations seen in HSQC or HMBC.

* a small amount of contaminating $\mathrm{PMP}_{2} \mathrm{~S}$ gave rise to resonances at: 55.5 (HSQC to an impurity proton at 3.81 ), 114.6 (HSQC to an impurity proton at 6.82), 133.6 (HSQC to an impurity proton at 7.39), and 160.0 (ipso to OMe).

* $38 \mathrm{Csp} 2$ carbons observed of the total of 42 ; the four $\mathrm{CF}_{3}$-bearing sp²-carbons (and none of the $\mathrm{CF}_{3}$ carbons) were identified.

${ }^{19}$ F NMR $\left(471 \mathrm{MHz}, \mathrm{CDCl}_{3}\right): \delta-62.52,-62.88,-62.90$, and -62.91.

HRMS $(\mathrm{APCl}) \mathrm{m} / \mathrm{z}$ : $[\mathrm{M}+\mathrm{H}]^{+}$Calcd for $\mathrm{C}_{76} \mathrm{H}_{41} \mathrm{~F}_{12} \mathrm{O}_{3}{ }^{+}$requires 1229.2864; found 1229.2857 .

IR (neat): 3072, 2932, 2852, 1666, 1604, 1323, 1168, and $1128 \mathrm{~cm}^{-1}$.

mp: $269-272{ }^{\circ} \mathrm{C}$. 


\title{
2,3,10,11-Tetramethoxy-7,14-dimethyl-5,13-ditosyl-8,15-bis(trimethylsilyl)-5,13-dihydrofuro[2,3-a:4,5- a]dicarbazole (19-S)
}

\author{
6,7-Dimethoxy-2-(4-methoxyphenoxy)-1-((4-methoxyphenyl)thio)-3-methyl-9-tosyl-4-(trimethylsilyl)-9H- \\ carbazole (20) \\ and
}

\section{2-Chloro-6,7-dimethoxy-3-methyl-9-tosyl-4-(trimethylsilyl)-9H-carbazole (21)}
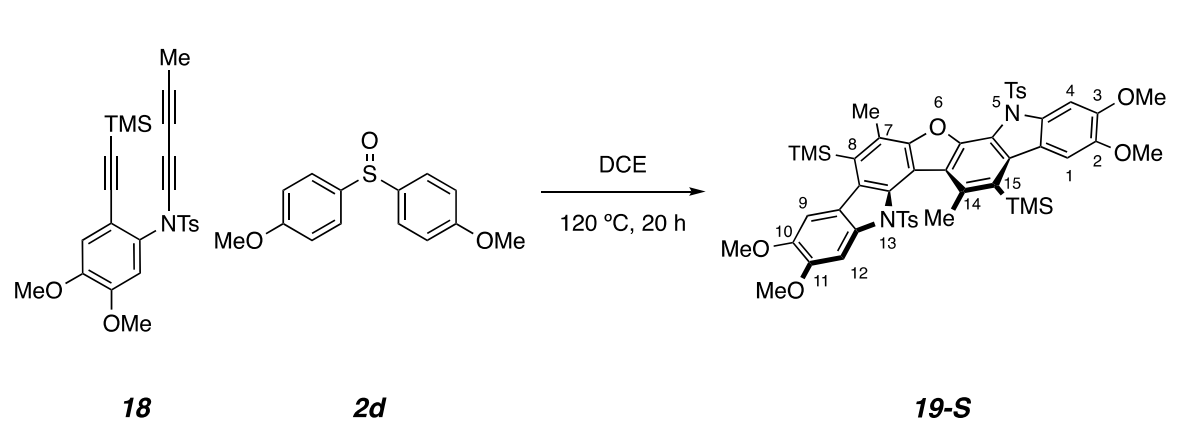

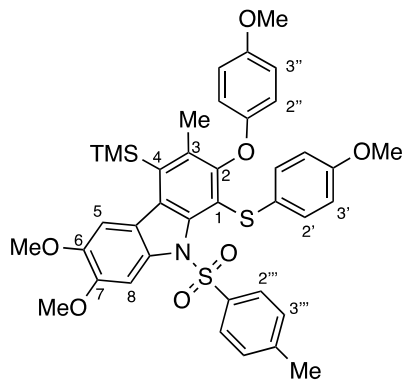

20

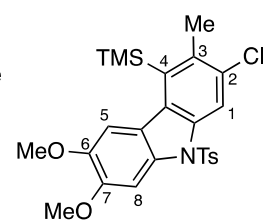

21

General procedure C was followed using triyne 18 (102 mg, $0.22 \mathrm{mmol}, 2.2$ equiv) and 4,4'-sulfinylbis(methoxybenzene (2d, $26 \mathrm{mg}$, $0.10 \mathrm{mmol}, 1.0$ equiv) to prepare compounds 19-S, 20, and 21. Purification by flash chromatography (3:1 hexanes/EtOAc) followed by MPLC (5:1 hexanes/EtOAc) yielded, in order of elution, unreacted $18(10 \mathrm{mg}), 21$ (10 mg, $0.01 \mathrm{mmol}, 20 \%)$ as a white crystalline solid, 20 (8 mg, $0.01 \mathrm{mmol}, 11 \%)$ as a white crystalline solid, and 19-S* $(44 \mathrm{mg}, 0.04 \mathrm{mmol}, 44 \%)$ as a white crystalline solid $(75 \%$ overall). *Decomposition to a monodesilylated derivative of 19-S spontaneously occurred, albeit slowly, over time. This was observable in the ${ }^{1} \mathrm{H}, \mathrm{HMBC}$, and NOESY spectra, which were taken two months following the original isolation and purification of the product.

\section{Data for furodicarbazole 19-S:}

The assignments of protons and carbons at positions $6 a-13 b$ (i.e., the left hand carbazole, as drawn) vs. those at positions $13 c-5 b$ (i.e., the right hand carbazole) rests upon the assumption that the C14-Me protons (at $3.29 \mathrm{ppm}$ ) are deshielded relative to those of the C7-Me group (2.92 ppm). This is further supported by the C7 vs. C14 shifts (127.1 and $140.6 \mathrm{ppm}$, respectively) clearly identified by the HMBC correlation with their attached methyl group protons. The assignment of resonances within each individual carbazole unit follows from extensive iterative interpretation of the HSQC, HMBC, and NOESY spectra.

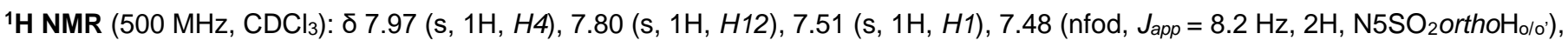

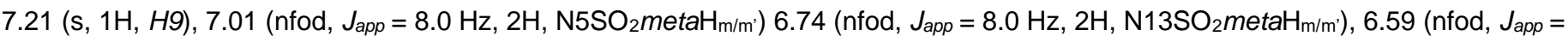

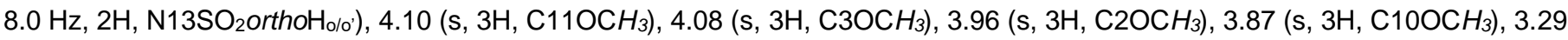

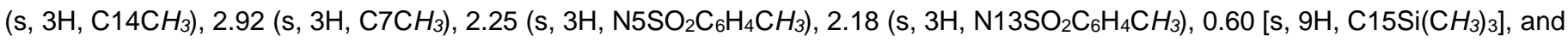
$0.41\left[\mathrm{~s}, 9 \mathrm{H}, \mathrm{C} 8 \mathrm{Si}\left(\mathrm{CH}_{3}\right)_{3}\right]$.

${ }^{13} \mathrm{C}$ NMR (125 MHz, CDCl $)$ : $\delta$ 154.6(C6a), 148.7(C3), 147.9(C11), 147.0(C10), 146.3(C2), 144.5, 144.4, 140.6(C14), 135.7(C12a),

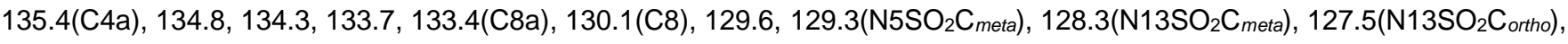
127.1(C7), 126.90( $\mathrm{N5SO}_{2} \mathrm{C}_{\text {ortho) }}, 126.86$ (C15), 125.0(C8b), 124.4(C13c), 122.4, 122.1(C15b), 118.0(C13b), 107.3(C9), 107.2(C1), 103.4(C12), 100.7(C4), 56.6 $\left({\left.\mathrm{C} 11 O C \mathrm{CH}_{3}\right), 56.5\left(\mathrm{C}_{3} \mathrm{OCH}\right.}_{3}\right), 56.30\left(\mathrm{C}_{2} \mathrm{OCH}\right), 56.27\left(\mathrm{C}_{3} 0 \mathrm{OCH}\right), 27.0\left(\mathrm{C}_{3} \mathrm{CH}_{3}\right), 21.6\left(\mathrm{~N}_{5} \mathrm{SO}_{2} \mathrm{C}_{6} \mathrm{H}_{4} \mathrm{CH}_{3}\right)$,

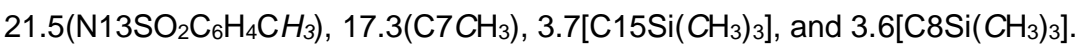

HRMS (ESI-TOF) $\mathrm{m} / \mathrm{z}$ : [M] ${ }^{+}$Calcd for $\mathrm{C}_{50} \mathrm{H}_{54} \mathrm{~N}_{2} \mathrm{O}_{9} \mathrm{~S}_{2} \mathrm{Si}_{2}{ }^{+}$requires 946.2809 ; found 946.2799 (note: this highly conjugated polycyclic aromatic compound ionized through electron loss rather than protonation or sodiation).

IR (neat): 2923, 2852, 1743(w), 1494, 1337, 1270, 1172, 1155, and $1089 \mathrm{~cm}^{-1}$.

mp: $139-141^{\circ} \mathrm{C}$. 


\section{Data for carbazole 20:}

${ }^{1} \mathrm{H} \mathrm{NMR}^{\star}\left(500 \mathrm{MHz}, \mathrm{CDCl}_{3}\right): \delta 7.68(\mathrm{~s}, 1 \mathrm{H}, \mathrm{H8}), 7.14(\mathrm{~s}, 1 \mathrm{H}, \mathrm{H5}), 6.99$ [nfod, Japp $=8.8 \mathrm{~Hz}, 2 \mathrm{H}, \mathrm{H} 2$ ], 6.94 [nfod, Japp $=8.3 \mathrm{~Hz}, 2 \mathrm{H}$, $H 2$ '”, 6.89 [nfod, Japp $=8.3 \mathrm{~Hz}, 2 \mathrm{H}, H 3$ '”], 6.83 [nfod, Japp $=9.1 \mathrm{~Hz}, 2 \mathrm{H}, \mathrm{H2}$ '], 6.68 [nfod, Japp $=8.8 \mathrm{~Hz}, 2 \mathrm{H}, H 3$ ], 6.61 [nfod, Japp =

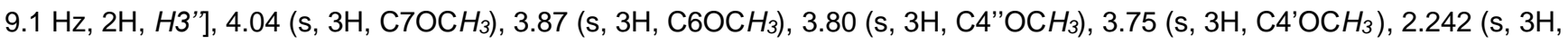
$\left.\mathrm{C}_{3} \mathrm{CH}_{3}\right), 2.237\left(\mathrm{~s}, 3 \mathrm{H}, \mathrm{C} 4\right.$ '" $\left.\mathrm{CH}_{3}\right)$, and $0.33\left[\mathrm{~s}, 9 \mathrm{H}, \mathrm{Si}\left(\mathrm{CH}_{3}\right)_{3}\right]$.

${ }^{13} \mathrm{C} \mathrm{NMR}^{*}$ (125 MHz, CDCl 3 ) ס 158.5(C4'), 154.4(C4"), 151.6(C1"), 151.1(C2), 148.5(C7), 147.1(C6), 144.4(C4"'), 142.3, 137.7(C3), 137.1(C8a), 135.0, 133.1(C4), 131.9(C2'), 131.2(C1'”), 128.7(C1'), 128.6(C3"'), 127.5(C2'”), 125.9, 123.9(C4b), 115.4(C3"), 114.7(C2"), 114.0(C3'), 107.2(C5), 103.6(C8), 56.6( $\left.\mathrm{C} 7 \mathrm{OCH}_{3}\right), 56.3\left(\mathrm{C}^{\prime} \mathrm{OCH}\right), 55.8\left(\mathrm{C}_{3} \mathrm{COCH}_{3}\right), 55.3\left(\mathrm{C}^{\prime} \mathrm{OCH}_{3}\right), 21.6\left(\mathrm{C}^{\prime \prime \prime} \mathrm{CH}_{3}\right)$, 18.7 $\left(\mathrm{C}_{3} \mathrm{CH}_{3}\right)$, and $3.2\left[\mathrm{Si}\left(\mathrm{CH}_{3}\right)_{3}\right]$. * Minor contamination by $19-\mathrm{S}$ is evident.

HRMS (ESI-TOF) m/z: [M + H] $]^{+}$Calcd for $\mathrm{C}_{39} \mathrm{H}_{42} \mathrm{NO}_{7} \mathrm{~S}_{2} \mathrm{Si}^{+}$requires 728.2172; found 728.2176.

IR (neat): 2998, 2950, 2935, 2834, 1594, 1492, 1338, 1239, 1201, and $1170 \mathrm{~cm}^{-1}$.

mp: $193-195^{\circ} \mathrm{C}$.

Data for carbazole 21:

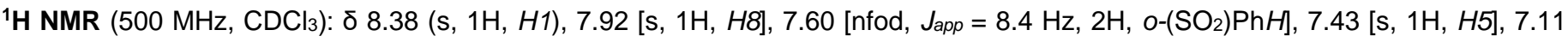

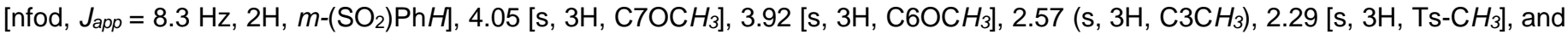
$0.51\left[\mathrm{~s}, 9 \mathrm{H}, \mathrm{Si}\left(\mathrm{CH}_{3}\right)_{3}\right]$.

${ }^{13} \mathrm{C}$ NMR $\left(125 \mathrm{MHz}, \mathrm{CDCl}_{3}\right): \delta 149.1,145.9,145.1,137.6,137.2,134.6,134.2,133.7,132.9,131.1,129.8,126.6,119.3,116.9,107.4$, $98.6,56.5,56.3,22.6,21.7$, and 3.5.

NOESY $\left(500 \mathrm{MHz}, \mathrm{CDCl}_{3}\right)$ : An NOE correlation between $\mathrm{H} 1$ and the tolyl protons ortho to the $\mathrm{ArNSO}_{2}$ substituent support the assigned constitution of this net $\mathrm{HCl}$ addition product.

HRMS (ESI-TOF) m/z: [M + H] $]^{+}$Calcd for $\mathrm{C}_{25} \mathrm{H}_{29}{ }^{35} \mathrm{CINO}_{4} \mathrm{SSi}^{+}$requires 502.1275 ; found 502.1256.

IR (neat): $3000,2952,2904,2834,1597,1434,1364,1192,1163$, and $1013 \mathrm{~cm}^{-1}$.

mp: $164-166^{\circ} \mathrm{C}$. 


\section{Reaction optimization for dibenzofuran synthesis}

The optimization of the reaction of triyne $\mathbf{7}$ to products $\mathbf{8}, \mathbf{9 - S}$, and $\mathbf{9 - U}$ or $\mathbf{9 - U}$ ' is summarized below in Table S1. All reactions were performed following General Procedure $\mathrm{C}$ with the exceptions that are listed for each entry. Ratios of product distributions were calculated using ${ }^{1} \mathrm{H}$ NMR analysis of the crude reaction mixtures. Entry 1 shows the result of the initial experiment performed in this study prior to optimization. Entries 2 and 3 were performed in NMR tubes and were heated to $60{ }^{\circ} \mathrm{C}$ in a mineral oil bath for 90 hours.

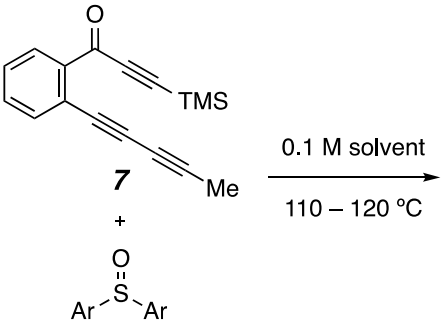

2

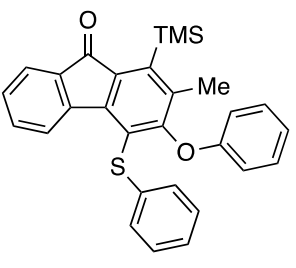

8

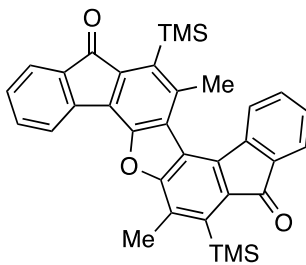

9-S

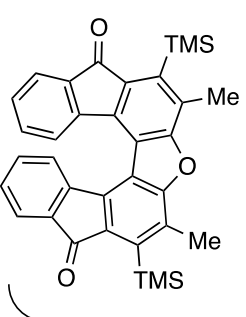

$9-U$
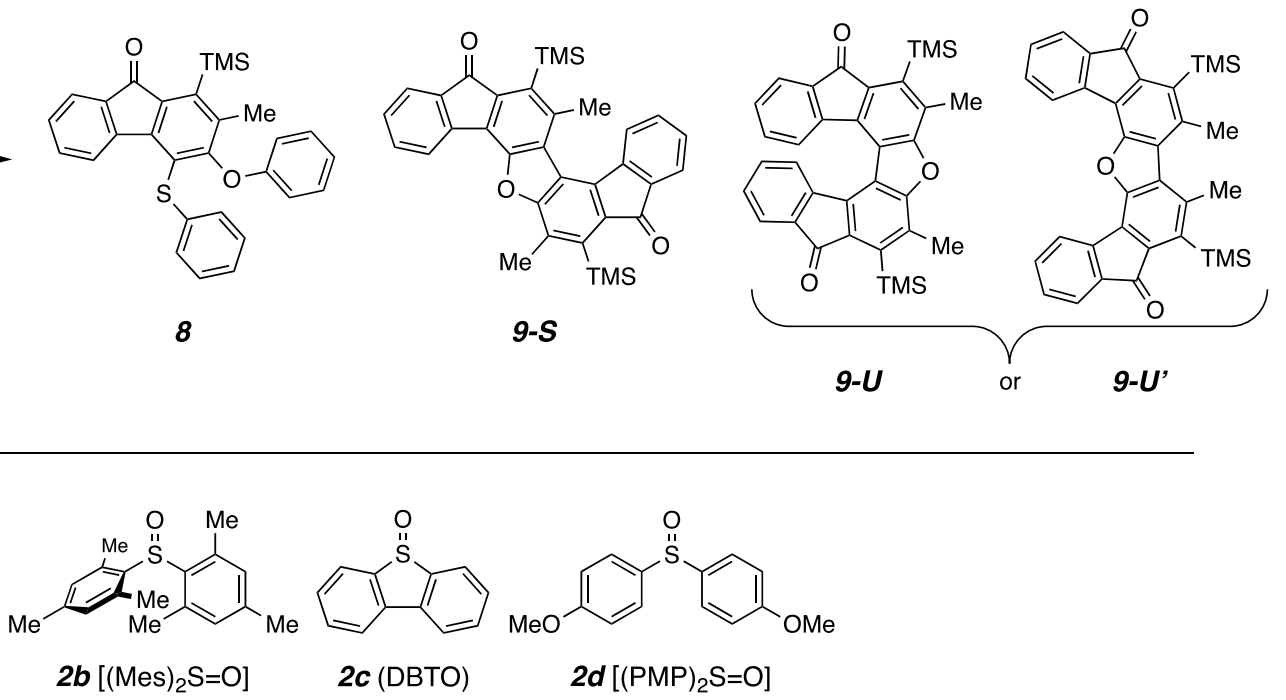

Table S1: Optimization for synthesis of dibenzofuran 9-S

\begin{tabular}{|c|c|c|c|}
\hline solvent & \# equiv of $\mathbf{7}$ & diaryl sulfoxide & $\begin{array}{c}\text { product ratio (NMR): } \\
\text { 9-S : 9-U/U': }\end{array}$ \\
\hline $\mathrm{CH}_{3} \mathrm{CN}$ & 3.0 & $\mathrm{Ph}_{2} \mathrm{~S}=\mathrm{O}(\mathbf{2 a})$ & $3.4: 1: 7$ \\
\hline $\mathrm{CDCl}_{3}$ & 4.0 & $\mathrm{Ph}_{2} \mathrm{~S}=\mathrm{O}(\mathbf{2 a})$ & $5: 1: 11$ \\
\hline $\mathrm{C}_{6} \mathrm{D}_{6}$ & 4.0 & $\mathrm{Ph}_{2} \mathrm{~S}=\mathrm{O}(\mathbf{2 a})$ & $1: 0: 1.5$ \\
\hline $\mathrm{C}_{6} \mathrm{D}_{6}$ & 4.0 & $\mathrm{Mes}_{2} \mathrm{~S}=\mathrm{O}(\mathbf{2 b})$ & $1: 0: 3.3$ \\
\hline $\mathrm{C}_{6} \mathrm{D}_{6}$ & 4.0 & $\mathrm{DBTO}(\mathbf{2 c})$ & $1: 0: 1.3$ \\
\hline $\mathrm{C}_{6} \mathrm{D}_{6}$ & 4.0 & $\mathrm{PMP}_{2} \mathrm{~S}=\mathrm{O}(\mathbf{2 d})$ & $1: 0: 0$ \\
\hline $\mathrm{C}_{6} \mathrm{D}_{6}$ & 2.2 & $\mathrm{PMP}_{2} \mathrm{~S}=\mathrm{O}(\mathbf{2 d})$ & $1: 0: 0$ \\
\hline $\mathrm{DCE}$ & 2.2 & $\mathrm{PMP}_{2} \mathrm{~S}=\mathrm{O}(\mathbf{2 d})$ & $(55 \%$ isolated yield $)$ \\
\hline
\end{tabular}

Note: the final entry corresponds to the conditions described in General Procedure C. 


\title{
V. Computational methods, discussion, and results
}

\begin{abstract}
- Methods
All DFT calculations were performed using Gaussian $16^{14}$. The geometry of each structure was optimized at the M06-2X/6-31G(d) ${ }^{15}$ level of theory with the SMD ${ }^{16}$ solvation model using dichloroethane. The nature of each optimized structure was verified by performing a frequency calculation ( $298 \mathrm{~K}$, at the same level of theory), which showed zero imaginary frequencies. Single point energies were then calculated at the M06-2X/6-311+G(d,p)/SMD(dichloroethane) level of theory on each optimized geometry to obtain more accurate energies. The Gaussian keywords "opt=calcfc" and "integral=ultrafine" were used in all optimization and frequency calculations.
\end{abstract}

Structures for the reactants and products (some truncated to simplify the conformational profile of the actual species, while maintaining the essential electronic and steric features) 7-nor-TMS, 2a; the intermediate $\mathrm{XIII}$; and products 27 and $\mathrm{Ph} 2 \mathrm{~S}$ (as well as the alternative possible product pair $\mathbf{2 6}$ and biphenyl) were initially subjected to a Monte Carlo conformational search using the OPLS_2005 molecular mechanics force field in MacroModel (version 10.1) within Maestro (version 9.4) in the Schrodinger software suite (release 2020-4) ${ }^{17}$. For 7-nor-TMS and XIII several conformers were found. These were optimized using the DFT methods described below. The lowest energy optimized geometry was then further subjected to a single-point calculation. For Ph2S, biphenyl, 2a, 27, and $\mathbf{2 6}$ only a single conformer was found in the force field calculation; each of these five (as well as a single input geometry for the benzyne XIV) was subjected to the same optimization and subsequent single-point calculation. The sulfurane intermediate $\mathbf{X V}$ was not well-treated by any of several MM force fields. Therefore, its starting geometry was built in Gaussview and used for the DFT calculations. The energies given in Figure S1 are the final single-point energies for each structure.

Starting geometries for transition state structures were initially identified using the Redundant Coordinate Editor (using Scan Coordinate). Prospective structures were then optimized using either the Berny or TS3 calculation at the M06-2X/6-

$31 \mathrm{G}(\mathrm{d}) / \mathrm{SMD}$ (dichloroethane) level of theory with the "opt=calcfc", "integral=ultrafine", and "guess=(mix,always)" keywords. In addition, the keyword "opt=noeigen" was used for all Berny calculations. Transition state structures were confirmed by frequency calculations, which showed a single imaginary frequency along the transformation pathway.

The following information is provided below for each structure shown in Figure S1:

A three-dimensional view of the optimized structure, prepared using CYLview2018

The "Sum of the electronic and thermal Free Energies" in Hartree (from the initial optimization/frequency calculation)

The energy from the final single-point calculation ("E") in Hartree

The Cartesian coordinates calculated at the M06-2X/6-31G(d)/SMD(dichloroethane) level of theory

The structures for all the products 9-S, 9-U-closed, 9-U-open, 11-S, ${ }^{*} \mathbf{1 1 - U},{ }^{*} \mathbf{1 3 - S}, \mathbf{1 5 - S}, \mathbf{1 7 - S},{ }^{*}$ and 19-S* were computed [M06$2 \mathrm{X} / 6-31 \mathrm{G}(\mathrm{d}) / \mathrm{SMD}$ (dichloroethane)] to evaluate the twisted nature of their geometry. *(also truncated to simplify the conformational profile of the actual species, while maintaining their essential electronic and steric features)

The following information is provided below for each of these structures:

A three-dimensional view of the optimized structure, prepared using CYLview20

The "Sum of the electronic and thermal Free Energies" in Hartree (from the initial optimization/frequency calculation)

The Cartesian coordinates calculated at the M06-2X/6-31G(d)/SMD(dichloroethane) level of theory

\section{- Methods check for calculating tetraaryl $\sigma$-sulfuranes}

Two functionals ( $\omega B 97 X-D$ and M06-2X), two basis sets (6-31G(d) and 6-311+G(d,p)), and a solvation model (SMD(dichloroethane) vs. a gas phase calculation were used to evaluate the structure of bis(2,2'-biphenylylene)sulfurane (S10). The resulting theoretical bond lengths and angles were compared to the corresponding experimental values for the X-ray crystal structure of $\mathbf{S 1 0}$ reported by Furukawa and coworkers ${ }^{19}$ using methodology for geometry comparison (bond lengths and angles) analogous to that used by McNally and Paton. ${ }^{20}$ These results are summarized in Table S2.

Table S2: Comparison of bond and angle lengths

\begin{tabular}{|l|c|c|c|c|}
\hline & & & \\
\end{tabular}

Overall, both functionals and basis sets gave theoretical values that were in high agreement with the experimental values. The average differences in bond lengths were all within $0.02 \AA$ [largest (LORTEP-LDFT) $=0.026 \AA$ ] for all combinations of functionals/basis sets/solvation models. The average differences in bond angles were all within $1.6^{\circ}\left(\right.$ largest difference $\left.=2.06^{\circ}\right)$ for all combinations 
of functionals/basis sets/solvation models. The incorporation of the SMD solvation model did not significantly affect the calculated sulfurane bond and angle values compared to the experimental results. This study ascertained that the M06-2X/6$31 \mathrm{G}(\mathrm{d}) / \mathrm{SMD}$ (dichloroethane) level of theory was an appropriate choice for calculating tetraaryl $\sigma$-sulfurane species.

\section{- Discussion}

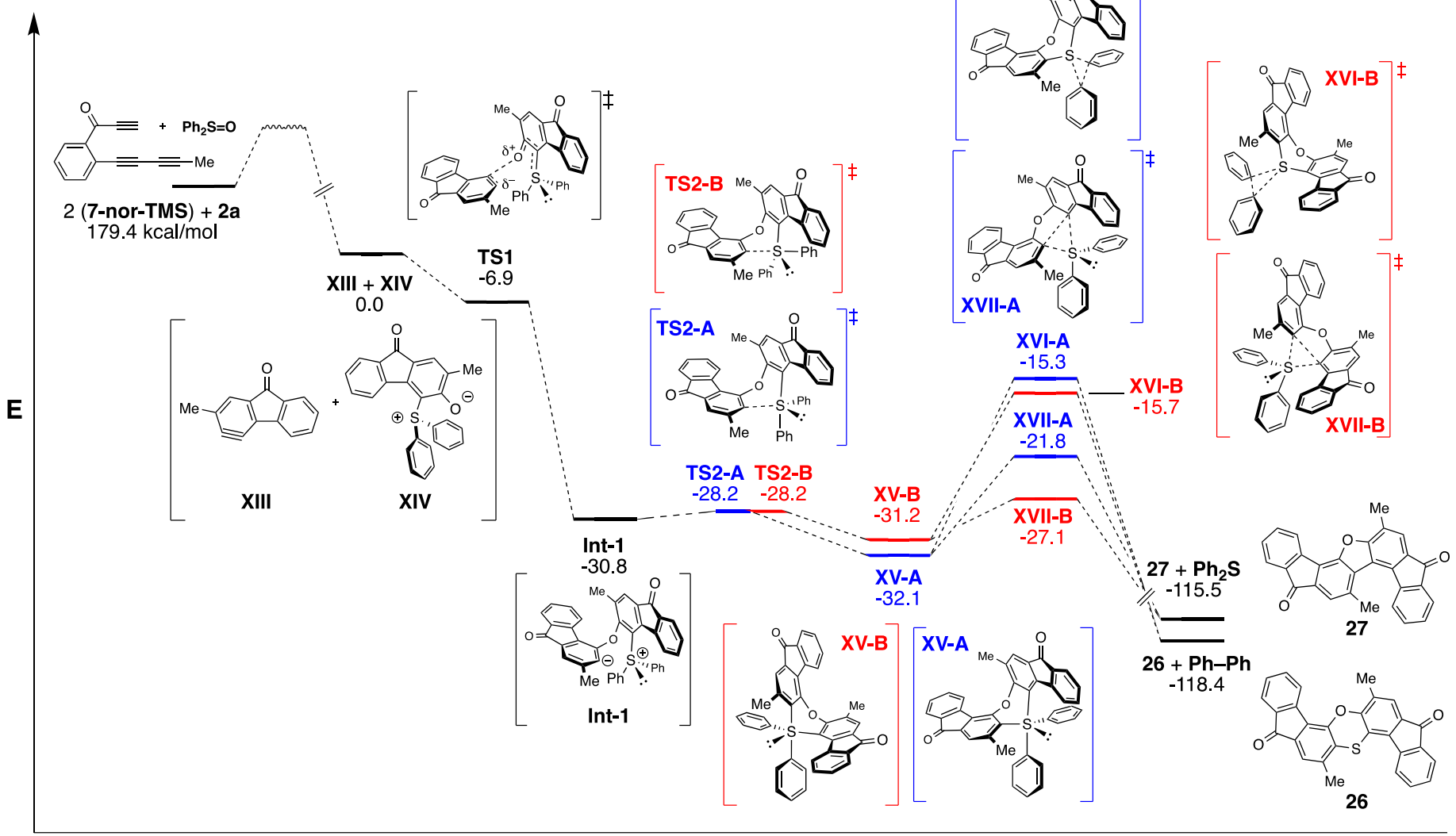

reaction coordinate

Figure S1: Free energy diagram of the proposed reaction pathway of structures 7-nor-TMS and 2a to phenoxathiine 26 and dibenzofuran 27. Structures were calculated at the (SMD: $\left.\mathrm{C}_{2} \mathrm{H}_{4} \mathrm{Cl}_{2}\right) / \mathrm{M} 06-2 \mathrm{X} / 6-311+\mathrm{G}(\mathrm{d}, \mathrm{p}) / /\left(\mathrm{SMD}: \mathrm{C}_{2} \mathrm{H}_{4} \mathrm{Cl}_{2}\right) / \mathrm{MO6}^{-}$ $2 \mathrm{X} / 6-31 \mathrm{G}(\mathrm{d})$ level of theory.

Highlights of further details than the essential ones described in the manuscript are mentioned here. We did not focus on the intermediates or TS(s) intervening between the starting materials 7-nor-TMS (2 molecules) and sulfoxide $2 \mathbf{a}$. However, other computations of sulfoxide trapping of benzyne(s) suggest activation barriers of ca. $5-10 \mathrm{kcal} / \mathrm{mol}$ for conversion to 1,6-zwitterion (sulfur ylide) analogs of XIII.21 The reaction of XIV with another copy of the benzyne XIII is computed to be barrierless and would be largely governed by the encounter frequency between these two reactive, low steady-state concentration species. The 1,6zwitterion Int-1 is computed to cyclize to two Berry pseudorotamers of the $\sigma$-sulfuranes XV-A (blue) and XV-B (red) via two equienergetic TSs; the activation barrier is $<3 \mathrm{kcal} / \mathrm{mol}$. Each sulfurane is computed to reductively eliminate $\mathrm{PhSPh}$ faster to give $\mathbf{2 7}$ $+\mathrm{PhSPh}$ in preference to ejection of PhPh required to form $\mathbf{2 6}+\mathbf{P h P h}$. Only the red B-series is described in the manuscript for simplicity, because both the A- and B-series of structures lead to the same mechanistic conclusions.

\section{- Energies and Cartesian coordinates}


Free Energy and Geometry for 7a-nor-TMS

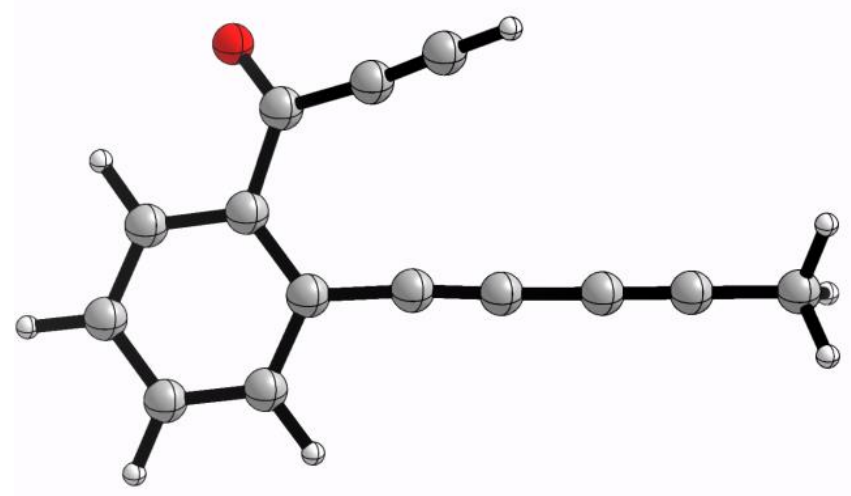

Sum of electronic and thermal free energies: -612.971295 a.u.

$\mathrm{E}\left[\left(\mathrm{SMD}: \mathrm{C}_{2} \mathrm{H}_{4} \mathrm{Cl}_{2}\right) / \mathrm{M} 06-2 \mathrm{X} / 6-311+\mathrm{G}^{* *} / /\left(\mathrm{SMD}: \mathrm{C}_{2} \mathrm{H}_{4} \mathrm{Cl}_{2}\right) / \mathrm{M} 06-2 \mathrm{X} / 6-31 \mathrm{G}^{*}\right]=-613.262962865$ a.u.

Number of imaginary frequencies: 0

\begin{tabular}{|c|c|c|c|c|c|}
\hline \multirow{2}{*}{$\begin{array}{l}\text { Center } \\
\text { Number }\end{array}$} & \multirow{2}{*}{$\begin{array}{l}\text { Atomic } \\
\text { Number }\end{array}$} & \multirow{2}{*}{$\begin{array}{c}\text { Atomic } \\
\text { Type }\end{array}$} & \multicolumn{3}{|c|}{ Coordinates (Ångstroms) } \\
\hline & & & $X$ & $\mathrm{Y}$ & $\mathrm{Z}$ \\
\hline 1 & 6 & 0 & -1.40800 & -2.09320 & 0.15820 \\
\hline 2 & 6 & 0 & -0.87900 & -0.79650 & 0.04520 \\
\hline 3 & 6 & 0 & -1.76600 & 0.29600 & -0.06980 \\
\hline 4 & 6 & 0 & -3.14430 & 0.06110 & -0.08070 \\
\hline 5 & 6 & 0 & -3.65410 & -1.22430 & 0.04270 \\
\hline 6 & 6 & 0 & -2.78010 & -2.30400 & 0.16440 \\
\hline 7 & 6 & 0 & -1.35220 & 1.72740 & -0.19440 \\
\hline 8 & 6 & 0 & -0.06920 & 2.16470 & 0.34610 \\
\hline 9 & 8 & 0 & -2.09850 & 2.55420 & -0.68590 \\
\hline 10 & 6 & 0 & 0.94650 & 2.62140 & 0.80980 \\
\hline 11 & 6 & 0 & 0.54550 & -0.67200 & 0.00220 \\
\hline 12 & 6 & 0 & 1.75870 & -0.66920 & -0.04510 \\
\hline 13 & 6 & 0 & 3.13170 & -0.61460 & -0.09480 \\
\hline 14 & 6 & 0 & 4.34240 & -0.55730 & -0.13780 \\
\hline 15 & 6 & 0 & 5.79720 & -0.49040 & -0.19210 \\
\hline 16 & 1 & 0 & -0.72220 & -2.93030 & 0.23490 \\
\hline 17 & 1 & 0 & -3.80980 & 0.91240 & -0.17780 \\
\hline 18 & 1 & 0 & -4.72720 & -1.38450 & 0.04460 \\
\hline 19 & 1 & 0 & -3.16660 & -3.31370 & 0.26010 \\
\hline 20 & 1 & 0 & 1.85830 & 3.00560 & 1.22160 \\
\hline 21 & 1 & 0 & 6.15260 & 0.46540 & 0.20420 \\
\hline 22 & 1 & 0 & 6.24080 & -1.29650 & 0.39970 \\
\hline 23 & 1 & 0 & 6.14690 & -0.58720 & -1.22430 \\
\hline
\end{tabular}


Free Energy and Geometry for 2a

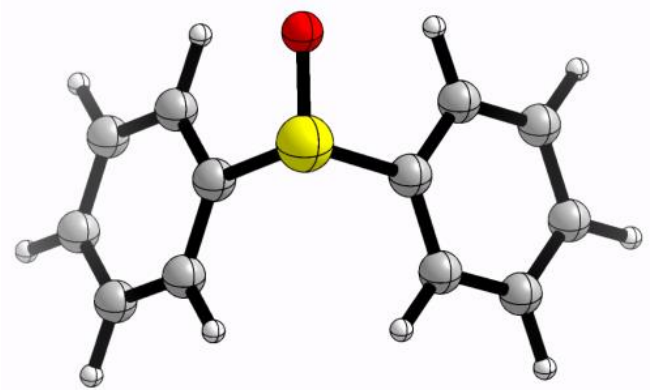

Sum of electronic and thermal free energies: -936.259425 a.u.

$\mathrm{E}\left[\left(\mathrm{SMD}: \mathrm{C}_{2} \mathrm{H}_{4} \mathrm{Cl}_{2}\right) / \mathrm{M} 06-2 \mathrm{X} / 6-311+\mathrm{G}^{* *} / /\left(\mathrm{SMD}: \mathrm{C}_{2} \mathrm{H}_{4} \mathrm{Cl}_{2}\right) / \mathrm{M} 06-2 \mathrm{X} / 6-31 \mathrm{G}^{*}\right]=-936.583645731$ a.u.

Number of imaginary frequencies: 0

\begin{tabular}{|c|c|c|c|c|c|}
\hline \multirow{2}{*}{$\begin{array}{l}\text { Center } \\
\text { Number }\end{array}$} & \multirow{2}{*}{$\begin{array}{l}\text { Atomic } \\
\text { Number }\end{array}$} & \multirow{2}{*}{$\begin{array}{c}\text { Atomic } \\
\text { Type }\end{array}$} & \multicolumn{3}{|c|}{ Coordinates (Ångstroms) } \\
\hline & & & $X$ & Y & $\mathrm{Z}$ \\
\hline 1 & 6 & 0 & 2.86650 & -1.57840 & -0.46000 \\
\hline 2 & 6 & 0 & 1.81650 & -0.84240 & -1.00440 \\
\hline 3 & 6 & 0 & 1.35650 & 0.27660 & -0.31650 \\
\hline 4 & 6 & 0 & 1.92970 & 0.69240 & 0.87890 \\
\hline 5 & 6 & 0 & 2.98340 & -0.04790 & 1.41020 \\
\hline 6 & 6 & 0 & 3.44710 & -1.18200 & 0.74450 \\
\hline 7 & 16 & 0 & -0.00230 & 1.25190 & -1.00250 \\
\hline 8 & 8 & 0 & -0.01940 & 2.55670 & -0.23780 \\
\hline 9 & 6 & 0 & -1.35260 & 0.25540 & -0.32700 \\
\hline 10 & 6 & 0 & -1.71960 & -0.93020 & -0.95760 \\
\hline 11 & 6 & 0 & -2.77040 & -1.67360 & -0.42670 \\
\hline 12 & 6 & 0 & -3.44350 & -1.22170 & 0.70880 \\
\hline 13 & 6 & 0 & -3.07020 & -0.02490 & 1.31780 \\
\hline 14 & 6 & 0 & -2.01660 & 0.72550 & 0.79850 \\
\hline 15 & 1 & 0 & 3.23720 & -2.45520 & -0.98160 \\
\hline 16 & 1 & 0 & 1.37000 & -1.13490 & -1.95160 \\
\hline 17 & 1 & 0 & 1.55240 & 1.58600 & 1.36790 \\
\hline 18 & 1 & 0 & 3.44380 & 0.26190 & 2.34340 \\
\hline 19 & 1 & 0 & 4.26970 & -1.75490 & 1.16130 \\
\hline 20 & 1 & 0 & -1.19840 & -1.27040 & -1.84920 \\
\hline 21 & 1 & 0 & -3.06870 & -2.60170 & -0.90430 \\
\hline 22 & 1 & 0 & -4.26630 & -1.80190 & 1.11520 \\
\hline 23 & 1 & 0 & -3.60050 & 0.32710 & 2.19740 \\
\hline 24 & 1 & 0 & -1.70780 & 1.66650 & 1.24440 \\
\hline
\end{tabular}


Free Energy and Geometry for the benzyne XIII

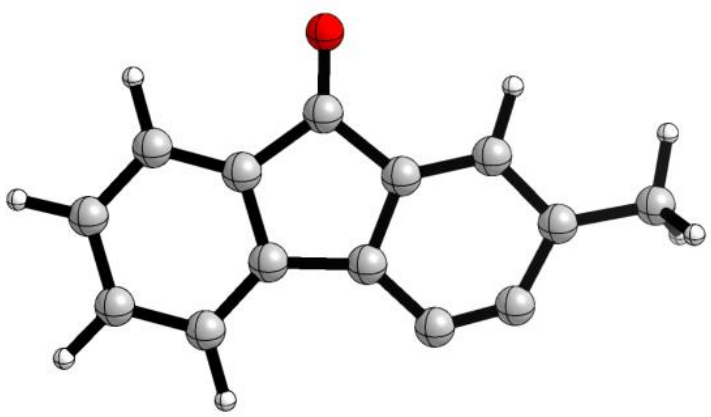

Sum of electronic and thermal free energies: -613.042823 a.u.

$\mathrm{E}\left[\left(\mathrm{SMD}: \mathrm{C}_{2} \mathrm{H}_{4} \mathrm{Cl}_{2}\right) / \mathrm{M} 06-2 \mathrm{X} / 6-311+\mathrm{G}^{* *} / /\left(\mathrm{SMD}: \mathrm{C}_{2} \mathrm{H}_{4} \mathrm{Cl}_{2}\right) / \mathrm{M} 06-2 \mathrm{X} / 6-31 \mathrm{G}^{*}\right]=-613.33662013$ a.u.

Number of imaginary frequencies: 0

\begin{tabular}{|c|c|c|c|c|c|}
\hline \multirow{2}{*}{$\begin{array}{l}\text { Center } \\
\text { Number }\end{array}$} & \multirow{2}{*}{$\begin{array}{l}\text { Atomic } \\
\text { Number }\end{array}$} & \multirow{2}{*}{$\begin{array}{l}\text { Atomic } \\
\text { Type }\end{array}$} & \multicolumn{3}{|c|}{ Coordinates (Ångstroms) } \\
\hline & & & $X$ & $\mathrm{Y}$ & $\mathrm{Z}$ \\
\hline 1 & 6 & 0 & -0.58070 & 2.10160 & 0.00000 \\
\hline 2 & 6 & 0 & -1.81750 & 2.26940 & 0.00000 \\
\hline 3 & 6 & 0 & -2.88460 & 1.38590 & 0.00000 \\
\hline 4 & 6 & 0 & -2.35470 & 0.06930 & 0.00000 \\
\hline 5 & 6 & 0 & -0.98170 & -0.17510 & 0.00000 \\
\hline 6 & 6 & 0 & -0.00000 & 0.84670 & 0.00000 \\
\hline 7 & 6 & 0 & 1.35000 & 0.24730 & 0.00000 \\
\hline 8 & 6 & 0 & 1.20220 & -1.14990 & 0.00000 \\
\hline 9 & 6 & 0 & -0.25930 & -1.49160 & 0.00000 \\
\hline 10 & 6 & 0 & 2.29610 & -1.99520 & 0.00000 \\
\hline 11 & 6 & 0 & 3.57210 & -1.41820 & 0.00000 \\
\hline 12 & 6 & 0 & 3.72170 & -0.03200 & 0.00000 \\
\hline 13 & 6 & 0 & 2.61010 & 0.82140 & 0.00000 \\
\hline 14 & 6 & 0 & -4.34920 & 1.69620 & 0.00000 \\
\hline 15 & 8 & 0 & -0.74880 & -2.59970 & 0.00000 \\
\hline 16 & 1 & 0 & -3.04900 & -0.76850 & 0.00000 \\
\hline 17 & 1 & 0 & 2.16350 & -3.07330 & 0.00000 \\
\hline 18 & 1 & 0 & 4.45210 & -2.05340 & 0.00000 \\
\hline 19 & 1 & 0 & 4.71950 & 0.39610 & 0.00000 \\
\hline 20 & 1 & 0 & 2.73510 & 1.90000 & 0.00000 \\
\hline 21 & 1 & 0 & -4.93650 & 0.77550 & 0.00000 \\
\hline 22 & 1 & 0 & -4.62060 & 2.28300 & 0.88290 \\
\hline 23 & 1 & 0 & -4.62060 & 2.28300 & -0.88290 \\
\hline
\end{tabular}




\section{Free Energy and Geometry for XIV}

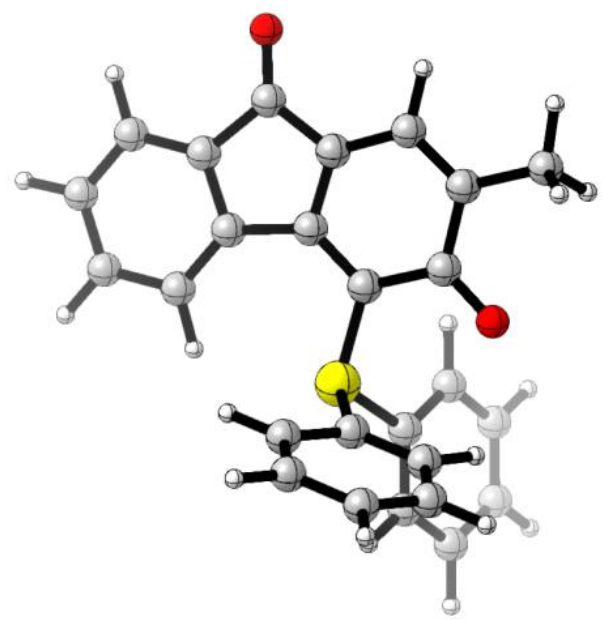

Sum of electronic and thermal free energies: -1549.415603 a.u.

$\mathrm{E}\left[\left(\mathrm{SMD}: \mathrm{C}_{2} \mathrm{H}_{4} \mathrm{Cl}_{2}\right) / \mathrm{M} 06-2 \mathrm{X} / 6-311+\mathrm{G}^{* *} / /\left(\mathrm{SMD}: \mathrm{C}_{2} \mathrm{H}_{4} \mathrm{Cl}_{2}\right) / \mathrm{M} 06-2 \mathrm{X} / 6-31 \mathrm{G}^{*}\right]=-1550.05891895$ a.u. Number of imaginary frequencies: 0

\begin{tabular}{|c|c|c|c|c|c|}
\hline \multirow{2}{*}{$\begin{array}{c}\text { Center } \\
\text { Number }\end{array}$} & \multirow{2}{*}{$\begin{array}{l}\text { Atomic } \\
\text { Number }\end{array}$} & \multirow{2}{*}{$\begin{array}{c}\text { Atomic } \\
\text { Type }\end{array}$} & \multicolumn{3}{|c|}{ Coordinates (Ångstroms) } \\
\hline & & & $\mathrm{X}$ & Y & $\mathrm{Z}$ \\
\hline 1 & 6 & 0 & 0.2773 & 0.5172 & -0.2216 \\
\hline 2 & 6 & 0 & -0.2831 & 1.6852 & -0.8915 \\
\hline 3 & 6 & 0 & 0.6818 & 2.633 & -1.441 \\
\hline 4 & 6 & 0 & 2.0261 & 2.4035 & -1.3153 \\
\hline 5 & 6 & 0 & 2.5133 & 1.2551 & -0.6555 \\
\hline 6 & 6 & 0 & 1.6515 & 0.3031 & -0.1058 \\
\hline 7 & 6 & 0 & 2.4771 & -0.7857 & 0.5143 \\
\hline 8 & 6 & 0 & 3.8282 & -0.4518 & 0.3121 \\
\hline 9 & 6 & 0 & 3.9044 & 0.8512 & -0.4345 \\
\hline 10 & 6 & 0 & 4.8631 & -1.2448 & 0.7607 \\
\hline 11 & 6 & 0 & 4.543 & -2.4261 & 1.4435 \\
\hline 12 & 6 & 0 & 3.212 & -2.7681 & 1.6531 \\
\hline 13 & 6 & 0 & 2.1634 & -1.9549 & 1.1934 \\
\hline 14 & 6 & 0 & 0.111 & 3.8351 & -2.1325 \\
\hline 15 & 8 & 0 & 4.9264 & 1.4241 & -0.7707 \\
\hline 16 & 8 & 0 & -1.5128 & 1.8673 & -0.9774 \\
\hline 17 & 16 & 0 & -0.8381 & -0.6798 & 0.3962 \\
\hline 18 & 6 & 0 & -1.9761 & 0.1427 & 1.5206 \\
\hline 19 & 6 & 0 & -1.8607 & -1.2538 & -0.9647 \\
\hline 20 & 6 & 0 & -1.4218 & -2.4319 & -1.5671 \\
\hline 21 & 6 & 0 & -2.1489 & -2.9484 & -2.6367 \\
\hline 22 & 6 & 0 & -3.3014 & -2.2986 & -3.0718 \\
\hline
\end{tabular}




\begin{tabular}{|c|c|c|c|c|c|}
\hline 23 & 6 & 0 & -3.7314 & -1.1282 & -2.4459 \\
\hline 24 & 6 & 0 & -3.0104 & -0.588 & -1.3855 \\
\hline 25 & 6 & 0 & -3.1168 & -0.5562 & 1.91 \\
\hline 26 & 6 & 0 & -3.9611 & 0.0193 & 2.8555 \\
\hline 27 & 6 & 0 & -3.6533 & 1.2615 & 3.4069 \\
\hline 28 & 6 & 0 & -2.4981 & 1.9346 & 3.0149 \\
\hline 29 & 6 & 0 & -1.646 & 1.3784 & 2.0641 \\
\hline 30 & 1 & 0 & 2.742 & 3.1122 & -1.7284 \\
\hline 31 & 1 & 0 & 5.8945 & -0.9519 & 0.585 \\
\hline 32 & 1 & 0 & 5.3328 & -3.074 & 1.8106 \\
\hline 33 & 1 & 0 & 2.9707 & -3.6834 & 2.1852 \\
\hline 34 & 1 & 0 & 1.1415 & -2.2601 & 1.3837 \\
\hline 35 & 1 & 0 & -0.532 & 3.5361 & -2.9682 \\
\hline 36 & 1 & 0 & -0.5199 & 4.4159 & -1.45 \\
\hline 37 & 1 & 0 & 0.9043 & 4.4831 & -2.5143 \\
\hline 38 & 1 & 0 & -0.5289 & -2.9385 & -1.2101 \\
\hline 39 & 1 & 0 & -1.8178 & -3.8624 & -3.1186 \\
\hline 40 & 1 & 0 & -3.8707 & -2.707 & -3.9009 \\
\hline 41 & 1 & 0 & -4.63 & -0.6255 & -2.7889 \\
\hline 42 & 1 & 0 & -3.3166 & 0.3322 & -0.9043 \\
\hline 43 & 1 & 0 & -3.3532 & -1.5267 & 1.4825 \\
\hline 44 & 1 & 0 & -4.8575 & -0.5102 & 3.1615 \\
\hline 45 & 1 & 0 & -4.314 & 1.7046 & 4.1452 \\
\hline 46 & 1 & 0 & -2.2564 & 2.9017 & 3.4436 \\
\hline 47 & 1 & 0 & -0.7461 & 1.8988 & 1.7532 \\
\hline
\end{tabular}




\section{Free Energy and Geometry for TS1}

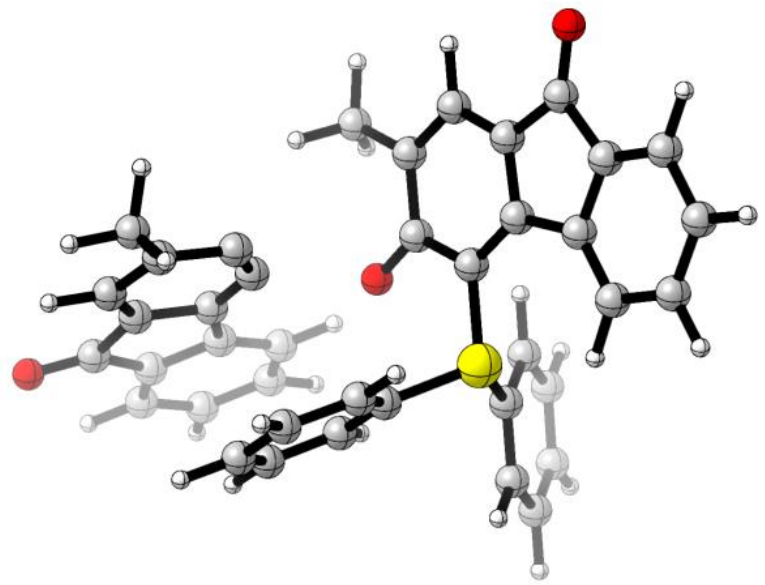

Sum of electronic and thermal free energies: -2162.448752 a.u.

$\mathrm{E}\left[\left(\mathrm{SMD}: \mathrm{C}_{2} \mathrm{H}_{4} \mathrm{Cl}_{2}\right) / \mathrm{M} 06-2 \mathrm{X} / 6-311+\mathrm{G}^{* *} / /\left(\mathrm{SMD}: \mathrm{C}_{2} \mathrm{H}_{4} \mathrm{Cl}_{2}\right) / \mathrm{M} 06-2 \mathrm{X} / 6-31 \mathrm{G}^{*}\right]=-2163.40656841$ a.u.

Number of imaginary frequencies: 1

\begin{tabular}{|c|c|c|c|c|c|}
\hline \multirow{2}{*}{$\begin{array}{l}\text { Center } \\
\text { Number }\end{array}$} & \multirow{2}{*}{$\begin{array}{l}\text { Atomic } \\
\text { Number }\end{array}$} & \multirow{2}{*}{$\begin{array}{c}\text { Atomic } \\
\text { Type }\end{array}$} & \multicolumn{3}{|c|}{ Coordinates (Ångstroms) } \\
\hline & & & $X$ & $\mathrm{Y}$ & $\mathrm{Z}$ \\
\hline 1 & 6 & 0 & -1.83950 & 0.16930 & -0.37860 \\
\hline 2 & 6 & 0 & -0.75190 & -0.09380 & -1.29710 \\
\hline 3 & 6 & 0 & -1.05440 & -0.92430 & -2.44500 \\
\hline 4 & 6 & 0 & -2.32570 & -1.41850 & -2.62020 \\
\hline 5 & 6 & 0 & -3.34630 & -1.13790 & -1.69650 \\
\hline 6 & 6 & 0 & -3.12300 & -0.34430 & -0.56860 \\
\hline 7 & 6 & 0 & -4.40320 & -0.24260 & 0.20530 \\
\hline 8 & 6 & 0 & -5.37330 & -0.98880 & -0.48770 \\
\hline 9 & 6 & 0 & -4.74860 & -1.58300 & -1.71750 \\
\hline 10 & 6 & 0 & -6.67390 & -1.10760 & -0.04400 \\
\hline 11 & 6 & 0 & -7.02890 & -0.45510 & 1.14380 \\
\hline 12 & 6 & 0 & -6.08050 & 0.28740 & 1.83880 \\
\hline 13 & 6 & 0 & -4.75880 & 0.40470 & 1.38070 \\
\hline 14 & 6 & 0 & 0.06180 & -1.17640 & -3.41430 \\
\hline 15 & 8 & 0 & -5.30680 & -2.28270 & -2.54210 \\
\hline 16 & 8 & 0 & 0.40030 & 0.37820 & -1.09760 \\
\hline 17 & 16 & 0 & -1.49580 & 1.12830 & 1.05000 \\
\hline 18 & 6 & 0 & -0.92430 & 2.74800 & 0.52640 \\
\hline 19 & 6 & 0 & -0.93960 & 3.12320 & -0.81140 \\
\hline 20 & 6 & 0 & -0.55130 & 4.42060 & -1.13940 \\
\hline 21 & 6 & 0 & -0.15650 & 5.31210 & -0.14470 \\
\hline 22 & 6 & 0 & -0.15840 & 4.91840 & 1.19270 \\
\hline
\end{tabular}




\begin{tabular}{|c|c|c|c|c|c|}
\hline 23 & 6 & 0 & -0.55430 & 3.63070 & 1.54040 \\
\hline 24 & 6 & 0 & 3.46290 & -3.15650 & 0.58060 \\
\hline 25 & 6 & 0 & 2.09790 & -3.52370 & 0.58100 \\
\hline 26 & 6 & 0 & 1.25040 & -2.54580 & 0.02630 \\
\hline 27 & 6 & 0 & 1.72780 & -1.46580 & -0.41020 \\
\hline 28 & 6 & 0 & 2.99630 & -0.97200 & -0.48660 \\
\hline 29 & 6 & 0 & 3.88350 & -1.93060 & 0.06220 \\
\hline 30 & 6 & 0 & 5.26110 & -1.34080 & 0.00470 \\
\hline 31 & 6 & 0 & 5.09450 & 0.02210 & -0.60540 \\
\hline 32 & 6 & 0 & 3.73600 & 0.23650 & -0.89590 \\
\hline 33 & 6 & 0 & 3.31180 & 1.43200 & -1.45460 \\
\hline 34 & 6 & 0 & 4.28290 & 2.40890 & -1.71840 \\
\hline 35 & 6 & 0 & 5.63030 & 2.19410 & -1.43240 \\
\hline 36 & 6 & 0 & 6.05200 & 0.98430 & -0.86600 \\
\hline 37 & 6 & 0 & 1.62660 & -4.83330 & 1.14640 \\
\hline 38 & 8 & 0 & 6.29690 & -1.84670 & 0.38030 \\
\hline 39 & 1 & 0 & -2.55580 & -2.03670 & -3.48620 \\
\hline 40 & 1 & 0 & -7.39490 & -1.69310 & -0.60750 \\
\hline 41 & 1 & 0 & -8.04350 & -0.52740 & 1.52240 \\
\hline 42 & 1 & 0 & -6.36310 & 0.79200 & 2.75780 \\
\hline 43 & 1 & 0 & -4.05560 & 0.99610 & 1.95450 \\
\hline 44 & 1 & 0 & -0.29350 & -1.73760 & -4.28250 \\
\hline 45 & 1 & 0 & 0.49890 & -0.23190 & -3.75730 \\
\hline 46 & 1 & 0 & 0.87270 & -1.74190 & -2.94160 \\
\hline 47 & 1 & 0 & -1.24910 & 2.42670 & -1.58230 \\
\hline 48 & 1 & 0 & -0.55630 & 4.72890 & -2.17970 \\
\hline 49 & 1 & 0 & 0.14780 & 6.31930 & -0.41100 \\
\hline 50 & 1 & 0 & 0.14060 & 5.61340 & 1.97030 \\
\hline 51 & 1 & 0 & -0.56300 & 3.31990 & 2.58170 \\
\hline 52 & 1 & 0 & 4.20090 & -3.83810 & 0.99810 \\
\hline 53 & 1 & 0 & 2.26140 & 1.59430 & -1.67440 \\
\hline 54 & 1 & 0 & 3.97640 & 3.35440 & -2.15600 \\
\hline 55 & 1 & 0 & 6.35650 & 2.97120 & -1.64890 \\
\hline 56 & 1 & 0 & 7.09780 & 0.80280 & -0.63450 \\
\hline 57 & 1 & 0 & 2.46220 & -5.42570 & 1.52810 \\
\hline 58 & 1 & 0 & 0.91730 & -4.66500 & 1.96420 \\
\hline 59 & 1 & 0 & 1.10530 & -5.42010 & 0.38290 \\
\hline 60 & 6 & 0 & -0.08420 & 0.37410 & 1.87000 \\
\hline 61 & 6 & 0 & -0.39510 & -0.72170 & 2.67180 \\
\hline 62 & 6 & 0 & 1.21400 & 0.85020 & 1.73030 \\
\hline 63 & 6 & 0 & 0.63860 & -1.37370 & 3.33890 \\
\hline 64 & 1 & 0 & -1.42140 & -1.06690 & 2.76810 \\
\hline 65 & 6 & 0 & 2.23070 & 0.20210 & 2.42700 \\
\hline 66 & 1 & 0 & 1.43360 & 1.68590 & 1.07460 \\
\hline 67 & 6 & 0 & 1.94810 & -0.91030 & 3.21840 \\
\hline 68 & 1 & 0 & 0.41580 & -2.23600 & 3.95900 \\
\hline 69 & 1 & 0 & 3.25250 & 0.55580 & 2.32620 \\
\hline 70 & 1 & 0 & 2.75170 & -1.41790 & 3.74290 \\
\hline
\end{tabular}




\section{Free Energy and Geometry for Int-1}

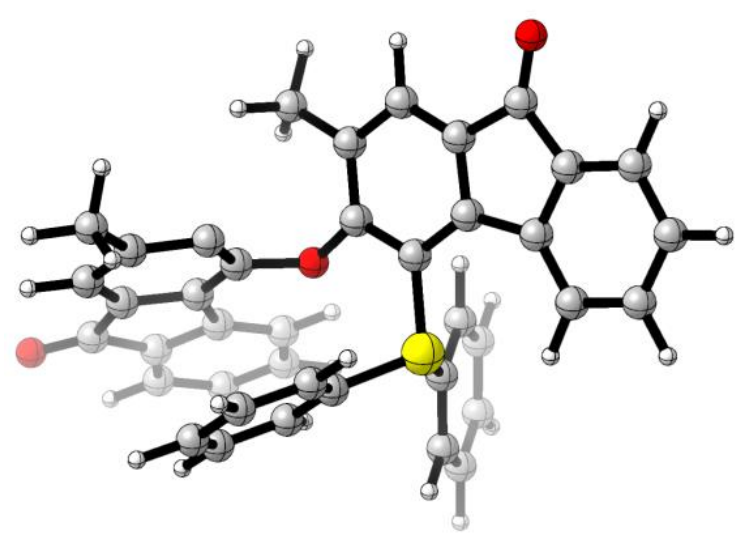

Sum of electronic and thermal free energies: -2162.479332 a.u.

$\mathrm{E}\left[\left(\mathrm{SMD}: \mathrm{C}_{2} \mathrm{H}_{4} \mathrm{Cl}_{2}\right) / \mathrm{M} 06-2 \mathrm{X} / 6-311+\mathrm{G}^{* *} / /\left(\mathrm{SMD}: \mathrm{C}_{2} \mathrm{H}_{4} \mathrm{Cl}_{2}\right) / \mathrm{M} 06-2 \mathrm{X} / 6-31 \mathrm{G}^{*}\right]=-2163.44457505$ a.u.

Number of imaginary frequencies: 0

\begin{tabular}{|c|c|c|c|c|c|}
\hline \multirow{2}{*}{$\begin{array}{l}\text { Center } \\
\text { Number }\end{array}$} & \multirow{2}{*}{$\begin{array}{l}\text { Atomic } \\
\text { Number }\end{array}$} & \multirow{2}{*}{$\begin{array}{c}\text { Atomic } \\
\text { Type }\end{array}$} & \multicolumn{3}{|c|}{ Coordinates (Ångstroms) } \\
\hline & & & $\mathrm{X}$ & Y & $\mathrm{Z}$ \\
\hline 1 & 6 & 0 & -1.74990 & -0.07620 & -0.20240 \\
\hline 2 & 6 & 0 & -0.74020 & -0.61540 & -1.03360 \\
\hline 3 & 6 & 0 & -1.07840 & -1.39170 & -2.15700 \\
\hline 4 & 6 & 0 & -2.42930 & -1.64080 & -2.39820 \\
\hline 5 & 6 & 0 & -3.40310 & -1.12080 & -1.56180 \\
\hline 6 & 6 & 0 & -3.09870 & -0.32000 & -0.45510 \\
\hline 7 & 6 & 0 & -4.37680 & 0.09450 & 0.20340 \\
\hline 8 & 6 & 0 & -5.43630 & -0.48060 & -0.52190 \\
\hline 9 & 6 & 0 & -4.88320 & -1.26780 & -1.66510 \\
\hline 10 & 6 & 0 & -6.76070 & -0.29350 & -0.17690 \\
\hline 11 & 6 & 0 & -7.04450 & 0.50120 & 0.93850 \\
\hline 12 & 6 & 0 & -6.00620 & 1.07980 & 1.66280 \\
\hline 13 & 6 & 0 & -4.66390 & 0.88750 & 1.30720 \\
\hline 14 & 6 & 0 & -0.01530 & -1.90870 & -3.08080 \\
\hline 15 & 8 & 0 & -5.50270 & -1.88900 & -2.50060 \\
\hline 16 & 8 & 0 & 0.53040 & -0.22700 & -0.78730 \\
\hline 17 & 16 & 0 & -1.31240 & 0.91160 & 1.20570 \\
\hline 18 & 6 & 0 & -0.56280 & 2.40710 & 0.55330 \\
\hline 19 & 6 & 0 & -0.64850 & 2.70750 & -0.80180 \\
\hline 20 & 6 & 0 & -0.13110 & 3.92420 & -1.24310 \\
\hline 21 & 6 & 0 & 0.46050 & 4.80660 & -0.34270 \\
\hline 22 & 6 & 0 & 0.52290 & 4.49010 & 1.01400 \\
\hline 23 & 6 & 0 & -0.00640 & 3.29040 & 1.47850 \\
\hline
\end{tabular}




\begin{tabular}{|c|c|c|c|c|c|}
\hline 24 & 6 & 0 & 3.53530 & -2.95800 & 0.17870 \\
\hline 25 & 6 & 0 & 2.18650 & -3.35510 & 0.22670 \\
\hline 26 & 6 & 0 & 1.10220 & -2.50180 & -0.10700 \\
\hline 27 & 6 & 0 & 1.50650 & -1.22850 & -0.50340 \\
\hline 28 & 6 & 0 & 2.81260 & -0.76730 & -0.57700 \\
\hline 29 & 6 & 0 & 3.83360 & -1.66570 & -0.22700 \\
\hline 30 & 6 & 0 & 5.14170 & -0.96760 & -0.32490 \\
\hline 31 & 6 & 0 & 4.81310 & 0.43770 & -0.74750 \\
\hline 32 & 6 & 0 & 3.41790 & 0.54860 & -0.89480 \\
\hline 33 & 6 & 0 & 2.85940 & 1.76640 & -1.25780 \\
\hline 34 & 6 & 0 & 3.71590 & 2.85620 & -1.47330 \\
\hline 35 & 6 & 0 & 5.09680 & 2.73580 & -1.33140 \\
\hline 36 & 6 & 0 & 5.66090 & 1.50730 & -0.96150 \\
\hline 37 & 6 & 0 & 1.87390 & -4.76340 & 0.69170 \\
\hline 38 & 8 & 0 & 6.25250 & -1.41170 & -0.10310 \\
\hline 39 & 1 & 0 & -2.72240 & -2.23610 & -3.25970 \\
\hline 40 & 1 & 0 & -7.55060 & -0.75430 & -0.76290 \\
\hline 41 & 1 & 0 & -8.07340 & 0.66960 & 1.23940 \\
\hline 42 & 1 & 0 & -6.23520 & 1.69760 & 2.52560 \\
\hline 43 & 1 & 0 & -3.89250 & 1.36150 & 1.90160 \\
\hline 44 & 1 & 0 & -0.45150 & -2.17780 & -4.04580 \\
\hline 45 & 1 & 0 & 0.76650 & -1.15950 & -3.23940 \\
\hline 46 & 1 & 0 & 0.46270 & -2.79090 & -2.64270 \\
\hline 47 & 1 & 0 & -1.10200 & 2.01790 & -1.50600 \\
\hline 48 & 1 & 0 & -0.18770 & 4.17220 & -2.29800 \\
\hline 49 & 1 & 0 & 0.86810 & 5.74800 & -0.69690 \\
\hline 50 & 1 & 0 & 0.97540 & 5.18000 & 1.71830 \\
\hline 51 & 1 & 0 & 0.03020 & 3.04730 & 2.53690 \\
\hline 52 & 1 & 0 & 4.33780 & -3.63920 & 0.45820 \\
\hline 53 & 1 & 0 & 1.78630 & 1.87480 & -1.37370 \\
\hline 54 & 1 & 0 & 3.28940 & 3.81460 & -1.75760 \\
\hline 55 & 1 & 0 & 5.73540 & 3.59610 & -1.50580 \\
\hline 56 & 1 & 0 & 6.73490 & 1.39310 & -0.84070 \\
\hline 57 & 1 & 0 & 2.77810 & -5.34760 & 0.89450 \\
\hline 58 & 1 & 0 & 1.27120 & -4.74160 & 1.60800 \\
\hline 59 & 1 & 0 & 1.28130 & -5.29920 & -0.05850 \\
\hline 60 & 6 & 0 & -0.02650 & -0.00170 & 2.06940 \\
\hline 61 & 6 & 0 & -0.48150 & -1.12980 & 2.74870 \\
\hline 62 & 6 & 0 & 1.30980 & 0.37680 & 2.05430 \\
\hline 63 & 6 & 0 & 0.44890 & -1.91440 & 3.42270 \\
\hline 64 & 1 & 0 & -1.53320 & -1.40380 & 2.74180 \\
\hline 65 & 6 & 0 & 2.22130 & -0.41150 & 2.75160 \\
\hline 66 & 1 & 0 & 1.64720 & 1.23820 & 1.48650 \\
\hline 67 & 6 & 0 & 1.79590 & -1.55510 & 3.42410 \\
\hline 68 & 1 & 0 & 0.11710 & -2.80570 & 3.94470 \\
\hline 69 & 1 & 0 & 3.27210 & -0.13970 & 2.74170 \\
\hline 70 & 1 & 0 & 2.51870 & -2.17220 & 3.94840 \\
\hline
\end{tabular}




\section{Free Energy and Geometry for TS2-A}

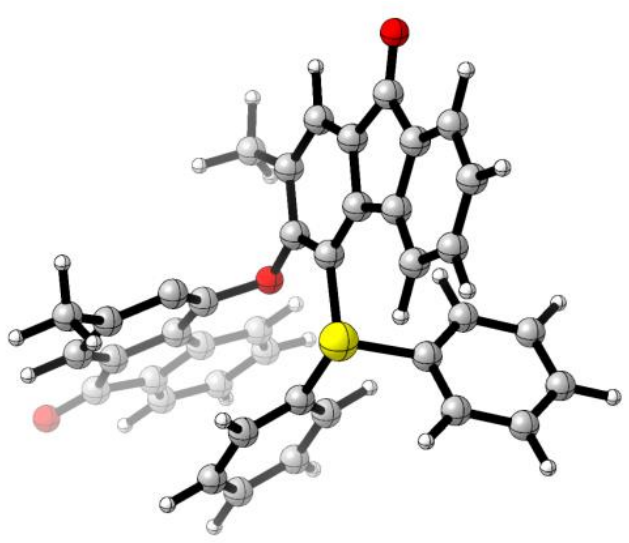

Sum of electronic and thermal free energies: -2162.476029 a.u.

$\mathrm{E}\left[\left(\mathrm{SMD}: \mathrm{C}_{2} \mathrm{H}_{4} \mathrm{Cl}_{2}\right) / \mathrm{M} 06-2 \mathrm{X} / 6-311+\mathrm{G}^{* *} / /\left(\mathrm{SMD}: \mathrm{C}_{2} \mathrm{H}_{4} \mathrm{Cl}_{2}\right) / \mathrm{M} 06-2 \mathrm{X} / 6-31 \mathrm{G}^{*}\right]=-2163.44043940$ a.u. Number of imaginary frequencies: 1

\begin{tabular}{|c|c|c|c|c|c|}
\hline \multirow{2}{*}{$\begin{array}{l}\text { Center } \\
\text { Number }\end{array}$} & \multirow{2}{*}{$\begin{array}{l}\text { Atomic } \\
\text { Number }\end{array}$} & \multirow{2}{*}{$\begin{array}{l}\text { Atomic } \\
\text { Type }\end{array}$} & \multicolumn{3}{|c|}{ Coordinates (Ångstroms) } \\
\hline & & & $X$ & $\mathrm{Y}$ & $\mathrm{Z}$ \\
\hline 1 & 6 & 0 & -1.43680 & -0.51120 & -0.16080 \\
\hline 2 & 6 & 0 & -0.38270 & -1.11030 & -0.87390 \\
\hline 3 & 6 & 0 & -0.61090 & -2.20260 & -1.72330 \\
\hline 4 & 6 & 0 & -1.91620 & -2.67140 & -1.87300 \\
\hline 5 & 6 & 0 & -2.93920 & -2.07780 & -1.15850 \\
\hline 6 & 6 & 0 & -2.73440 & -1.00940 & -0.27210 \\
\hline 7 & 6 & 0 & -4.04680 & -0.65640 & 0.35610 \\
\hline 8 & 6 & 0 & -5.02810 & -1.50310 & -0.19270 \\
\hline 9 & 6 & 0 & -4.38810 & -2.43320 & -1.16800 \\
\hline 10 & 6 & 0 & -6.35700 & -1.44590 & 0.18000 \\
\hline 11 & 6 & 0 & -6.73010 & -0.50740 & 1.14700 \\
\hline 12 & 6 & 0 & -5.76960 & 0.32730 & 1.71030 \\
\hline 13 & 6 & 0 & -4.42280 & 0.26490 & 1.32640 \\
\hline 14 & 6 & 0 & 0.55800 & -2.83000 & -2.42690 \\
\hline 15 & 8 & 0 & -4.92490 & -3.29520 & -1.82890 \\
\hline 16 & 8 & 0 & 0.87580 & -0.61400 & -0.80750 \\
\hline 17 & 16 & 0 & -1.21570 & 0.88500 & 0.94530 \\
\hline 18 & 6 & 0 & -2.00900 & 2.22800 & 0.04740 \\
\hline 19 & 6 & 0 & -2.17610 & 2.19220 & -1.33350 \\
\hline 20 & 6 & 0 & -2.78550 & 3.28160 & -1.95260 \\
\hline 21 & 6 & 0 & -3.21000 & 4.37330 & -1.19850 \\
\hline 22 & 6 & 0 & -3.03020 & 4.38890 & 0.18390 \\
\hline 23 & 6 & 0 & -2.42810 & 3.30880 & 0.82140 \\
\hline
\end{tabular}




\begin{tabular}{|c|c|c|c|c|c|}
\hline 24 & 6 & 0 & 3.51740 & -1.88310 & 2.16390 \\
\hline 25 & 6 & 0 & 2.14140 & -2.14220 & 2.29900 \\
\hline 26 & 6 & 0 & 1.17310 & -1.75640 & 1.33510 \\
\hline 27 & 6 & 0 & 1.72230 & -1.12500 & 0.22040 \\
\hline 28 & 6 & 0 & 3.06590 & -0.85100 & 0.01270 \\
\hline 29 & 6 & 0 & 3.96440 & -1.23780 & 1.01950 \\
\hline 30 & 6 & 0 & 5.33400 & -0.81610 & 0.62510 \\
\hline 31 & 6 & 0 & 5.17610 & -0.14670 & -0.71180 \\
\hline 32 & 6 & 0 & 3.81690 & -0.17610 & -1.07370 \\
\hline 33 & 6 & 0 & 3.41230 & 0.39430 & -2.27340 \\
\hline 34 & 6 & 0 & 4.38570 & 0.98440 & -3.09280 \\
\hline 35 & 6 & 0 & 5.73010 & 1.00960 & -2.72550 \\
\hline 36 & 6 & 0 & 6.13830 & 0.43600 & -1.51470 \\
\hline 37 & 6 & 0 & 1.66710 & -2.83970 & 3.55870 \\
\hline 38 & 8 & 0 & 6.37400 & -0.96150 & 1.23970 \\
\hline 39 & 1 & 0 & -2.12930 & -3.50500 & -2.53730 \\
\hline 40 & 1 & 0 & -7.08090 & -2.11980 & -0.26860 \\
\hline 41 & 1 & 0 & -7.76500 & -0.43330 & 1.46450 \\
\hline 42 & 1 & 0 & -6.06320 & 1.04610 & 2.46870 \\
\hline 43 & 1 & 0 & -3.72030 & 0.93140 & 1.81180 \\
\hline 44 & 1 & 0 & 0.22190 & -3.63360 & -3.08570 \\
\hline 45 & 1 & 0 & 1.10650 & -2.09120 & -3.01930 \\
\hline 46 & 1 & 0 & 1.26210 & -3.24690 & -1.69820 \\
\hline 47 & 1 & 0 & -1.84480 & 1.33900 & -1.91740 \\
\hline 48 & 1 & 0 & -2.92650 & 3.27150 & -3.02830 \\
\hline 49 & 1 & 0 & -3.68620 & 5.21560 & -1.68990 \\
\hline 50 & 1 & 0 & -3.36410 & 5.23790 & 0.77100 \\
\hline 51 & 1 & 0 & -2.28860 & 3.31020 & 1.89940 \\
\hline 52 & 1 & 0 & 4.22840 & -2.17540 & 2.93550 \\
\hline 53 & 1 & 0 & 2.36800 & 0.39070 & -2.56800 \\
\hline 54 & 1 & 0 & 4.08310 & 1.43380 & -4.03450 \\
\hline 55 & 1 & 0 & 6.46030 & 1.47520 & -3.38020 \\
\hline 56 & 1 & 0 & 7.18090 & 0.44570 & -1.20790 \\
\hline 57 & 1 & 0 & 2.49580 & -3.12040 & 4.21780 \\
\hline 58 & 1 & 0 & 0.98570 & -2.19560 & 4.12810 \\
\hline 59 & 1 & 0 & 1.10420 & -3.74720 & 3.31270 \\
\hline 60 & 6 & 0 & 0.47230 & 1.46670 & 1.09240 \\
\hline 61 & 6 & 0 & 1.07910 & 1.20840 & 2.31800 \\
\hline 62 & 6 & 0 & 1.10240 & 2.17860 & 0.07550 \\
\hline 63 & 6 & 0 & 2.37950 & 1.66610 & 2.52190 \\
\hline 64 & 1 & 0 & 0.55810 & 0.65110 & 3.08960 \\
\hline 65 & 6 & 0 & 2.39880 & 2.62680 & 0.29780 \\
\hline 66 & 1 & 0 & 0.60340 & 2.36680 & -0.86980 \\
\hline 67 & 6 & 0 & 3.03580 & 2.36580 & 1.51360 \\
\hline 68 & 1 & 0 & 2.87550 & 1.46440 & 3.46550 \\
\hline 69 & 1 & 0 & 2.91800 & 3.17040 & -0.48480 \\
\hline 70 & 1 & 0 & 4.05270 & 2.71190 & 1.67100 \\
\hline
\end{tabular}




\section{Free Energy and Geometry for TS2-B}

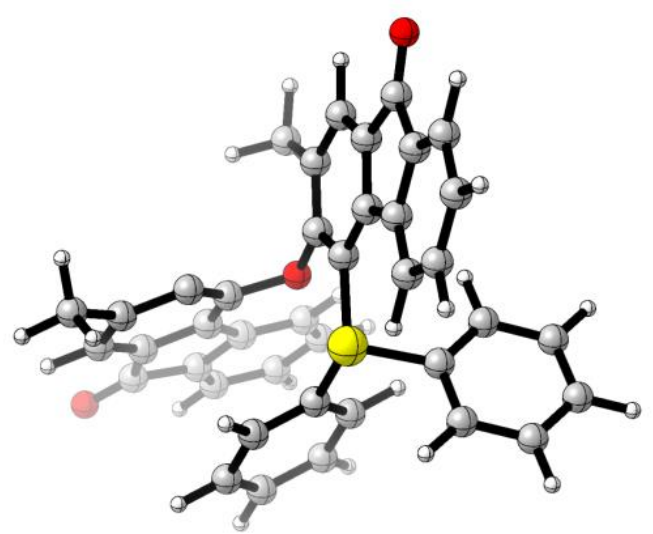

Sum of electronic and thermal free energies: -2162.475692 a.u.

$\mathrm{E}\left[\left(\mathrm{SMD}: \mathrm{C}_{2} \mathrm{H}_{4} \mathrm{Cl}_{2}\right) / \mathrm{M} 06-2 \mathrm{X} / 6-311+\mathrm{G}^{* *} / /\left(\mathrm{SMD}: \mathrm{C}_{2} \mathrm{H}_{4} \mathrm{Cl}_{2}\right) / \mathrm{M} 06-2 \mathrm{X} / 6-31 \mathrm{G}^{*}\right]=-2163.44043941$ a.u.

Number of imaginary frequencies: 1

\begin{tabular}{|c|c|c|c|c|c|}
\hline \multirow{2}{*}{$\begin{array}{l}\text { Center } \\
\text { Number }\end{array}$} & \multirow{2}{*}{$\begin{array}{l}\text { Atomic } \\
\text { Number }\end{array}$} & \multirow{2}{*}{$\begin{array}{c}\text { Atomic } \\
\text { Type }\end{array}$} & \multicolumn{3}{|c|}{ Coordinates (Ångstroms) } \\
\hline & & & $\mathrm{X}$ & Y & $\mathrm{Z}$ \\
\hline 1 & 6 & 0 & -1.43710 & -0.51120 & -0.16100 \\
\hline 2 & 6 & 0 & -0.38340 & -1.11030 & -0.87490 \\
\hline 3 & 6 & 0 & -0.61230 & -2.20170 & -1.72510 \\
\hline 4 & 6 & 0 & -1.91780 & -2.66980 & -1.87490 \\
\hline 5 & 6 & 0 & -2.94040 & -2.07620 & -1.15970 \\
\hline 6 & 6 & 0 & -2.73490 & -1.00860 & -0.27250 \\
\hline 7 & 6 & 0 & -4.04700 & -0.65530 & 0.35610 \\
\hline 8 & 6 & 0 & -5.02890 & -1.50100 & -0.19330 \\
\hline 9 & 6 & 0 & -4.38960 & -2.43070 & -1.16950 \\
\hline 10 & 6 & 0 & -6.35770 & -1.44320 & 0.17940 \\
\hline 11 & 6 & 0 & -6.73020 & -0.50530 & 1.14710 \\
\hline 12 & 6 & 0 & -5.76920 & 0.32840 & 1.71110 \\
\hline 13 & 6 & 0 & -4.42240 & 0.26530 & 1.32720 \\
\hline 14 & 6 & 0 & 0.55620 & -2.82920 & -2.42940 \\
\hline 15 & 8 & 0 & -4.92690 & -3.29180 & -1.83100 \\
\hline 16 & 8 & 0 & 0.87530 & -0.61450 & -0.80840 \\
\hline 17 & 16 & 0 & -1.21490 & 0.88380 & 0.94640 \\
\hline 18 & 6 & 0 & -2.00780 & 2.22800 & 0.04990 \\
\hline 19 & 6 & 0 & -2.17570 & 2.19360 & -1.33090 \\
\hline 20 & 6 & 0 & -2.78460 & 3.28390 & -1.94880 \\
\hline 21 & 6 & 0 & -3.20780 & 4.37540 & -1.19360 \\
\hline 22 & 6 & 0 & -3.02720 & 4.38970 & 0.18880 \\
\hline 23 & 6 & 0 & -2.42570 & 3.30860 & 0.82500 \\
\hline
\end{tabular}




\begin{tabular}{|c|c|c|c|c|c|}
\hline 24 & 6 & 0 & 3.51760 & -1.88670 & 2.16100 \\
\hline 25 & 6 & 0 & 2.14180 & -2.14690 & 2.29570 \\
\hline 26 & 6 & 0 & 1.17310 & -1.75950 & 1.33270 \\
\hline 27 & 6 & 0 & 1.72210 & -1.12710 & 0.21850 \\
\hline 28 & 6 & 0 & 3.06560 & -0.85260 & 0.01090 \\
\hline 29 & 6 & 0 & 3.96430 & -1.24010 & 1.01720 \\
\hline 30 & 6 & 0 & 5.33340 & -0.81560 & 0.62420 \\
\hline 31 & 6 & 0 & 5.17510 & -0.14430 & -0.71170 \\
\hline 32 & 6 & 0 & 3.81610 & -0.17480 & -1.07410 \\
\hline 33 & 6 & 0 & 3.41120 & 0.39710 & -2.27300 \\
\hline 34 & 6 & 0 & 4.38410 & 0.98970 & -3.09110 \\
\hline 35 & 6 & 0 & 5.72840 & 1.01620 & -2.72320 \\
\hline 36 & 6 & 0 & 6.13690 & 0.44100 & -1.51320 \\
\hline 37 & 6 & 0 & 1.66870 & -2.85260 & 3.55120 \\
\hline 38 & 8 & 0 & 6.37330 & -0.96040 & 1.23900 \\
\hline 39 & 1 & 0 & -2.13150 & -3.50270 & -2.53990 \\
\hline 40 & 1 & 0 & -7.08210 & -2.11630 & -0.26980 \\
\hline 41 & 1 & 0 & -7.76510 & -0.43070 & 1.46470 \\
\hline 42 & 1 & 0 & -6.06230 & 1.04670 & 2.47010 \\
\hline 43 & 1 & 0 & -3.71950 & 0.93100 & 1.81310 \\
\hline 44 & 1 & 0 & 0.21950 & -3.63140 & -3.08960 \\
\hline 45 & 1 & 0 & 1.10560 & -2.08990 & -3.02050 \\
\hline 46 & 1 & 0 & 1.25970 & -3.24790 & -1.70120 \\
\hline 47 & 1 & 0 & -1.84540 & 1.34060 & -1.91570 \\
\hline 48 & 1 & 0 & -2.92610 & 3.27490 & -3.02440 \\
\hline 49 & 1 & 0 & -3.68360 & 5.21850 & -1.68400 \\
\hline 50 & 1 & 0 & -3.36020 & 5.23850 & 0.77670 \\
\hline 51 & 1 & 0 & -2.28550 & 3.30900 & 1.90290 \\
\hline 52 & 1 & 0 & 4.22870 & -2.17870 & 2.93270 \\
\hline 53 & 1 & 0 & 2.36700 & 0.39250 & -2.56810 \\
\hline 54 & 1 & 0 & 4.08130 & 1.44030 & -4.03210 \\
\hline 55 & 1 & 0 & 6.45810 & 1.48380 & -3.37690 \\
\hline 56 & 1 & 0 & 7.17930 & 0.45160 & -1.20610 \\
\hline 57 & 1 & 0 & 1.18380 & -3.80430 & 3.30400 \\
\hline 58 & 1 & 0 & 2.48850 & -3.06160 & 4.24710 \\
\hline 59 & 1 & 0 & 0.91910 & -2.24990 & 4.07750 \\
\hline 60 & 6 & 0 & 0.47340 & 1.46470 & 1.09360 \\
\hline 61 & 6 & 0 & 1.08030 & 1.20520 & 2.31880 \\
\hline 62 & 6 & 0 & 1.10350 & 2.17730 & 0.07720 \\
\hline 63 & 6 & 0 & 2.38090 & 1.66230 & 2.52290 \\
\hline 64 & 1 & 0 & 0.55940 & 0.64740 & 3.09010 \\
\hline 65 & 6 & 0 & 2.40000 & 2.62500 & 0.29970 \\
\hline 66 & 1 & 0 & 0.60440 & 2.36650 & -0.86780 \\
\hline 67 & 6 & 0 & 3.03720 & 2.36280 & 1.51510 \\
\hline 68 & 1 & 0 & 2.87710 & 1.45960 & 3.46620 \\
\hline 69 & 1 & 0 & 2.91930 & 3.16920 & -0.48260 \\
\hline 70 & 1 & 0 & 4.05430 & 2.70840 & 1.67260 \\
\hline
\end{tabular}




\section{Free Energy and Geometry for XV-A}

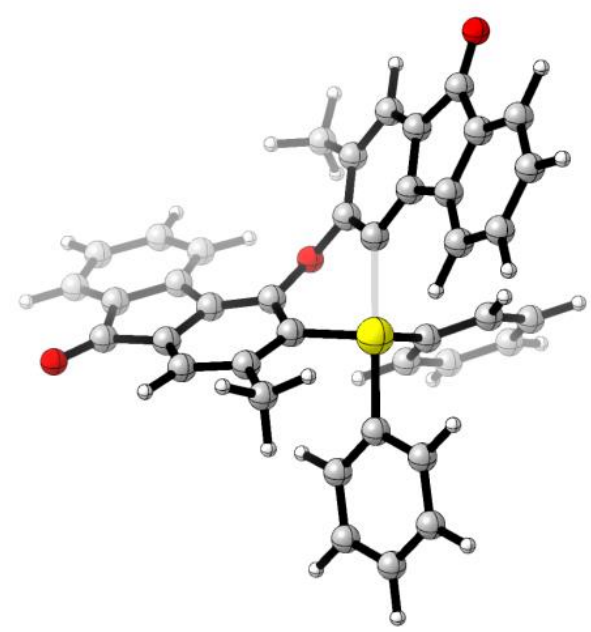

Sum of electronic and thermal free energies: -2162.489317 a.u.

$\mathrm{E}\left[\left(\mathrm{SMD}: \mathrm{C}_{2} \mathrm{H}_{4} \mathrm{Cl}_{2}\right) / \mathrm{M} 06-2 \mathrm{X} / 6-311+\mathrm{G}^{* *} / /\left(\mathrm{SMD}: \mathrm{C}_{2} \mathrm{H}_{4} \mathrm{Cl}_{2}\right) / \mathrm{M} 06-2 \mathrm{X} / 6-31 \mathrm{G}^{*}\right]=-2163.44674426$ a.u.

Number of imaginary frequencies: 0

\begin{tabular}{|c|c|c|c|c|c|}
\hline \multirow{2}{*}{$\begin{array}{l}\text { Center } \\
\text { Number }\end{array}$} & \multirow{2}{*}{$\begin{array}{l}\text { Atomic } \\
\text { Number }\end{array}$} & \multirow{2}{*}{$\begin{array}{l}\text { Atomic } \\
\text { Type }\end{array}$} & \multicolumn{3}{|c|}{ Coordinates (Ångstroms) } \\
\hline & & & $\mathrm{X}$ & Y & $\mathrm{Z}$ \\
\hline 1 & 6 & 0 & 1.18980 & -0.84090 & -0.15440 \\
\hline 2 & 6 & 0 & 0.22840 & -1.67040 & 0.42060 \\
\hline 3 & 6 & 0 & 0.40260 & -3.02020 & 0.75380 \\
\hline 4 & 6 & 0 & 1.64670 & -3.58580 & 0.45490 \\
\hline 5 & 6 & 0 & 2.61870 & -2.80680 & -0.15020 \\
\hline 6 & 6 & 0 & 2.40250 & -1.44980 & -0.45300 \\
\hline 7 & 6 & 0 & 3.65840 & -0.90540 & -1.04930 \\
\hline 8 & 6 & 0 & 4.61410 & -1.93540 & -1.09880 \\
\hline 9 & 6 & 0 & 4.00780 & -3.18500 & -0.53750 \\
\hline 10 & 6 & 0 & 5.88610 & -1.74080 & -1.60440 \\
\hline 11 & 6 & 0 & 6.21900 & -0.46690 & -2.07830 \\
\hline 12 & 6 & 0 & 5.27920 & 0.56130 & -2.03800 \\
\hline 13 & 6 & 0 & 3.98960 & 0.35570 & -1.52760 \\
\hline 14 & 6 & 0 & -0.70190 & -3.82090 & 1.38420 \\
\hline 15 & 8 & 0 & 4.54340 & -4.26850 & -0.42100 \\
\hline 16 & 8 & 0 & -1.02530 & -1.13190 & 0.72100 \\
\hline 17 & 16 & 0 & 0.80430 & 1.22160 & -0.12370 \\
\hline 18 & 6 & 0 & 0.94430 & 1.03810 & 1.67400 \\
\hline 19 & 6 & 0 & -0.15840 & 1.12080 & 2.51590 \\
\hline 20 & 6 & 0 & 0.03710 & 1.00000 & 3.89040 \\
\hline 21 & 6 & 0 & 1.31900 & 0.82190 & 4.40610 \\
\hline
\end{tabular}




\begin{tabular}{|c|c|c|c|c|c|}
\hline 22 & 6 & 0 & 2.41480 & 0.75280 & 3.54710 \\
\hline 23 & 6 & 0 & 2.23190 & 0.84790 & 2.17050 \\
\hline 24 & 6 & 0 & -2.62370 & 1.26670 & -2.29390 \\
\hline 25 & 6 & 0 & -1.30540 & 1.51150 & -1.88420 \\
\hline 26 & 6 & 0 & -0.80770 & 0.78760 & -0.78570 \\
\hline 27 & 6 & 0 & -1.54870 & -0.25180 & -0.18200 \\
\hline 28 & 6 & 0 & -2.87930 & -0.40880 & -0.54370 \\
\hline 29 & 6 & 0 & -3.39150 & 0.35910 & -1.59460 \\
\hline 30 & 6 & 0 & -4.81310 & -0.06230 & -1.83970 \\
\hline 31 & 6 & 0 & -5.09060 & -1.12110 & -0.82200 \\
\hline 32 & 6 & 0 & -3.93640 & -1.32160 & -0.04450 \\
\hline 33 & 6 & 0 & -3.95690 & -2.22360 & 1.00880 \\
\hline 34 & 6 & 0 & -5.14110 & -2.93460 & 1.24650 \\
\hline 35 & 6 & 0 & -6.27690 & -2.74430 & 0.46070 \\
\hline 36 & 6 & 0 & -6.26160 & -1.81930 & -0.58870 \\
\hline 37 & 6 & 0 & -0.49260 & 2.51620 & -2.66220 \\
\hline 38 & 8 & 0 & -5.56350 & 0.37130 & -2.68550 \\
\hline 39 & 1 & 0 & 1.84140 & -4.62960 & 0.68910 \\
\hline 40 & 1 & 0 & 6.60040 & -2.55910 & -1.62950 \\
\hline 41 & 1 & 0 & 7.20920 & -0.27800 & -2.48070 \\
\hline 42 & 1 & 0 & 5.54820 & 1.54440 & -2.41310 \\
\hline 43 & 1 & 0 & 3.27340 & 1.17110 & -1.51870 \\
\hline 44 & 1 & 0 & -0.35790 & -4.83390 & 1.60730 \\
\hline 45 & 1 & 0 & -1.04540 & -3.36070 & 2.31690 \\
\hline 46 & 1 & 0 & -1.56730 & -3.89030 & 0.71620 \\
\hline 47 & 1 & 0 & -1.15500 & 1.27770 & 2.11450 \\
\hline 48 & 1 & 0 & -0.81810 & 1.05110 & 4.55680 \\
\hline 49 & 1 & 0 & 1.46500 & 0.73700 & 5.47830 \\
\hline 50 & 1 & 0 & 3.41570 & 0.61800 & 3.94480 \\
\hline 51 & 1 & 0 & 3.07870 & 0.77120 & 1.49280 \\
\hline 52 & 1 & 0 & -3.03320 & 1.79700 & -3.14960 \\
\hline 53 & 1 & 0 & -3.08740 & -2.36970 & 1.63910 \\
\hline 54 & 1 & 0 & -5.17360 & -3.64620 & 2.06610 \\
\hline 55 & 1 & 0 & -7.17840 & -3.31090 & 0.67080 \\
\hline 56 & 1 & 0 & -7.13990 & -1.64610 & -1.20380 \\
\hline 57 & 1 & 0 & 0.58430 & 2.38140 & -2.53440 \\
\hline 58 & 1 & 0 & -0.72140 & 2.40730 & -3.72610 \\
\hline 59 & 1 & 0 & -0.74240 & 3.54010 & -2.36670 \\
\hline 60 & 6 & 0 & 0.28710 & 3.10140 & 0.16610 \\
\hline 61 & 6 & 0 & 1.36960 & 3.97210 & 0.06530 \\
\hline 62 & 6 & 0 & -0.97700 & 3.61900 & 0.45850 \\
\hline 63 & 6 & 0 & 1.20290 & 5.34560 & 0.24930 \\
\hline 64 & 1 & 0 & 2.36020 & 3.57720 & -0.16630 \\
\hline 65 & 6 & 0 & -1.14970 & 4.99050 & 0.64300 \\
\hline 66 & 1 & 0 & -1.84090 & 2.96010 & 0.53040 \\
\hline 67 & 6 & 0 & -0.06050 & 5.85650 & 0.53720 \\
\hline 68 & 1 & 0 & 2.05480 & 6.01450 & 0.16260 \\
\hline 69 & 1 & 0 & -2.13700 & 5.38540 & 0.86730 \\
\hline 70 & 1 & 0 & -0.19870 & 6.92450 & 0.67710 \\
\hline
\end{tabular}




\section{Free Energy and Geometry for XV-B}

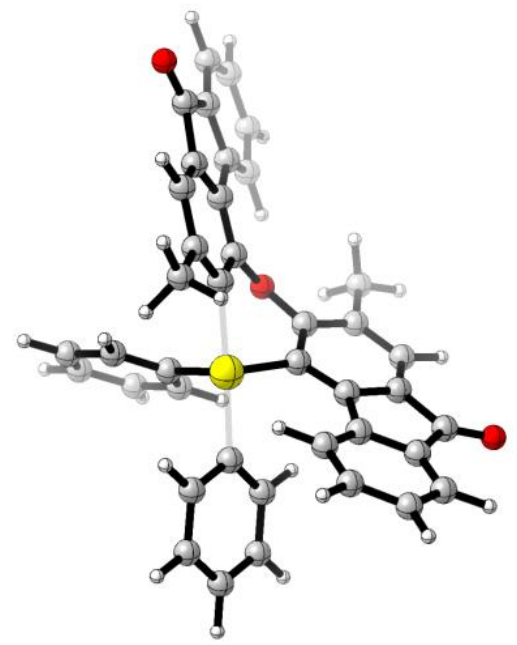

Sum of electronic and thermal free energies: -2162.487016 a.u.

$\mathrm{E}\left[\left(\mathrm{SMD}: \mathrm{C}_{2} \mathrm{H}_{4} \mathrm{Cl}_{2}\right) / \mathrm{M} 06-2 \mathrm{X} / 6-311+\mathrm{G}^{* *} / /\left(\mathrm{SMD}: \mathrm{C}_{2} \mathrm{H}_{4} \mathrm{Cl}_{2}\right) / \mathrm{M} 06-2 \mathrm{X} / 6-31 \mathrm{G}^{*}\right]=-2163.44519269$ a.u.

Number of imaginary frequencies: 0

\begin{tabular}{|c|c|c|c|c|c|}
\hline \multirow{2}{*}{$\begin{array}{l}\text { Center } \\
\text { Number }\end{array}$} & \multirow{2}{*}{$\begin{array}{l}\text { Atomic } \\
\text { Number }\end{array}$} & \multirow{2}{*}{$\begin{array}{c}\text { Atomic } \\
\text { Type }\end{array}$} & \multicolumn{3}{|c|}{ Coordinates (Ångstroms) } \\
\hline & & & $X$ & $\mathrm{Y}$ & $\mathrm{Z}$ \\
\hline 1 & 6 & 0 & -0.95260 & -0.63270 & -0.11090 \\
\hline 2 & 6 & 0 & 0.12340 & -1.19510 & -0.82800 \\
\hline 3 & 6 & 0 & 0.00750 & -2.41550 & -1.51410 \\
\hline 4 & 6 & 0 & -1.18900 & -3.12140 & -1.39980 \\
\hline 5 & 6 & 0 & -2.19420 & -2.63240 & -0.58350 \\
\hline 6 & 6 & 0 & -2.09930 & -1.40260 & 0.07960 \\
\hline 7 & 6 & 0 & -3.33010 & -1.21450 & 0.90450 \\
\hline 8 & 6 & 0 & -4.18030 & -2.30980 & 0.67600 \\
\hline 9 & 6 & 0 & -3.51880 & -3.25070 & -0.27660 \\
\hline 10 & 6 & 0 & -5.39880 & -2.44810 & 1.31500 \\
\hline 11 & 6 & 0 & -5.77860 & -1.45790 & 2.22570 \\
\hline 12 & 6 & 0 & -4.93090 & -0.38170 & 2.48170 \\
\hline 13 & 6 & 0 & -3.69760 & -0.24850 & 1.83140 \\
\hline 14 & 6 & 0 & 1.17250 & -2.94410 & -2.30170 \\
\hline 15 & 8 & 0 & -3.95550 & -4.29570 & -0.70830 \\
\hline 16 & 8 & 0 & 1.35000 & -0.59380 & -0.89050 \\
\hline 17 & 16 & 0 & -0.86060 & 1.05540 & 0.48390 \\
\hline 18 & 6 & 0 & -2.54730 & 1.57560 & -0.47310 \\
\hline 19 & 6 & 0 & -3.15570 & 1.00200 & -1.59140 \\
\hline 20 & 6 & 0 & -4.34210 & 1.53070 & -2.10230 \\
\hline 21 & 6 & 0 & -4.93360 & 2.64020 & -1.49920 \\
\hline
\end{tabular}




\begin{tabular}{|c|c|c|c|c|c|}
\hline 22 & 6 & 0 & -4.33030 & 3.22350 & -0.38660 \\
\hline 23 & 6 & 0 & -3.14360 & 2.68950 & 0.11620 \\
\hline 24 & 6 & 0 & 2.82840 & 0.80620 & 2.75370 \\
\hline 25 & 6 & 0 & 1.46960 & 0.98170 & 2.44090 \\
\hline 26 & 6 & 0 & 0.99310 & 0.55220 & 1.19610 \\
\hline 27 & 6 & 0 & 1.85180 & -0.07970 & 0.30200 \\
\hline 28 & 6 & 0 & 3.20400 & -0.21820 & 0.56530 \\
\hline 29 & 6 & 0 & 3.66560 & 0.23430 & 1.81140 \\
\hline 30 & 6 & 0 & 5.13080 & -0.05680 & 1.90440 \\
\hline 31 & 6 & 0 & 5.49250 & -0.70030 & 0.60030 \\
\hline 32 & 6 & 0 & 4.33980 & -0.78620 & -0.20000 \\
\hline 33 & 6 & 0 & 4.42160 & -1.31390 & -1.48000 \\
\hline 34 & 6 & 0 & 5.66870 & -1.77000 & -1.92950 \\
\hline 35 & 6 & 0 & 6.80500 & -1.69490 & -1.12560 \\
\hline 36 & 6 & 0 & 6.72450 & -1.14730 & 0.16010 \\
\hline 37 & 6 & 0 & 0.54090 & 1.63540 & 3.43760 \\
\hline 38 & 8 & 0 & 5.87090 & 0.17750 & 2.83660 \\
\hline 39 & 1 & 0 & -1.31420 & -4.07150 & -1.91270 \\
\hline 40 & 1 & 0 & -6.03070 & -3.30840 & 1.11380 \\
\hline 41 & 1 & 0 & -6.72900 & -1.53150 & 2.74440 \\
\hline 42 & 1 & 0 & -5.22820 & 0.37250 & 3.20380 \\
\hline 43 & 1 & 0 & -3.05900 & 0.59620 & 2.06590 \\
\hline 44 & 1 & 0 & 0.90000 & -3.87790 & -2.79850 \\
\hline 45 & 1 & 0 & 1.49570 & -2.22660 & -3.06290 \\
\hline 46 & 1 & 0 & 2.02970 & -3.13480 & -1.64730 \\
\hline 47 & 1 & 0 & -2.71550 & 0.13120 & -2.07490 \\
\hline 48 & 1 & 0 & -4.80690 & 1.07370 & -2.97200 \\
\hline 49 & 1 & 0 & -5.85990 & 3.04670 & -1.89450 \\
\hline 50 & 1 & 0 & -4.78550 & 4.08760 & 0.09000 \\
\hline 51 & 1 & 0 & -2.67990 & 3.14790 & 0.99260 \\
\hline 52 & 1 & 0 & 3.22330 & 1.12410 & 3.71610 \\
\hline 53 & 1 & 0 & 3.54900 & -1.36490 & -2.12180 \\
\hline 54 & 1 & 0 & 5.75000 & -2.18700 & -2.92890 \\
\hline 55 & 1 & 0 & 7.75640 & -2.05680 & -1.50220 \\
\hline 56 & 1 & 0 & 7.60040 & -1.07010 & 0.79800 \\
\hline 57 & 1 & 0 & -0.31960 & 0.99410 & 3.65650 \\
\hline 58 & 1 & 0 & 1.06140 & 1.83790 & 4.37740 \\
\hline 59 & 1 & 0 & 0.14510 & 2.58680 & 3.06350 \\
\hline 60 & 6 & 0 & 0.02670 & 2.15320 & -0.66020 \\
\hline 61 & 6 & 0 & 0.64570 & 3.27250 & -0.10990 \\
\hline 62 & 6 & 0 & 0.06270 & 1.89980 & -2.02660 \\
\hline 63 & 6 & 0 & 1.29800 & 4.16610 & -0.95580 \\
\hline 64 & 1 & 0 & 0.62300 & 3.44770 & 0.96180 \\
\hline 65 & 6 & 0 & 0.74040 & 2.78840 & -2.85820 \\
\hline 66 & 1 & 0 & -0.43300 & 1.02750 & -2.44220 \\
\hline 67 & 6 & 0 & 1.35170 & 3.92210 & -2.32680 \\
\hline 68 & 1 & 0 & 1.76950 & 5.04960 & -0.53730 \\
\hline 69 & 1 & 0 & 0.78310 & 2.59300 & -3.92510 \\
\hline 70 & 1 & 0 & 1.86990 & 4.61580 & -2.98130 \\
\hline
\end{tabular}




\section{Free Energy and Geometry for XVII-A}

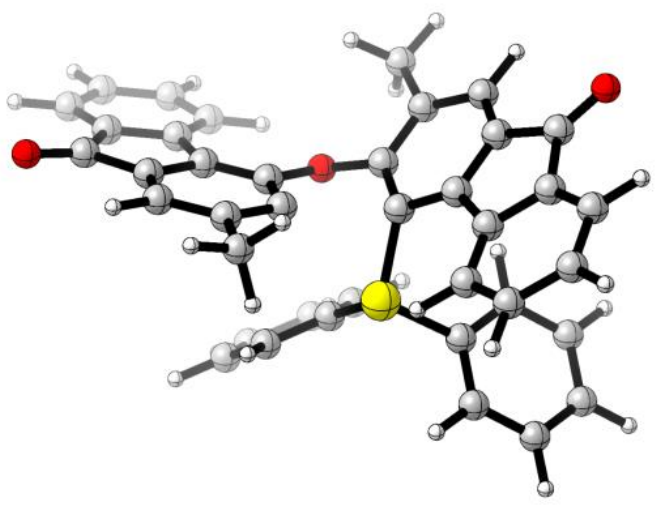

Sum of electronic and thermal free energies: -2162.472360 a.u.

$\mathrm{E}\left[\left(\mathrm{SMD}: \mathrm{C}_{2} \mathrm{H}_{4} \mathrm{Cl}_{2}\right) / \mathrm{M} 06-2 \mathrm{X} / 6-311+\mathrm{G}^{* *} / /\left(\mathrm{SMD}: \mathrm{C}_{2} \mathrm{H}_{4} \mathrm{Cl}_{2}\right) / \mathrm{M} 06-2 \mathrm{X} / 6-31 \mathrm{G}^{*}\right]=-2163.43029034$ a.u.

Number of imaginary frequencies: 1

\begin{tabular}{|c|c|c|c|c|c|}
\hline \multirow{2}{*}{$\begin{array}{l}\text { Center } \\
\text { Number }\end{array}$} & \multirow{2}{*}{$\begin{array}{l}\text { Atomic } \\
\text { Number }\end{array}$} & \multirow{2}{*}{$\begin{array}{l}\text { Atomic } \\
\text { Type }\end{array}$} & \multicolumn{3}{|c|}{ Coordinates (Ångstroms) } \\
\hline & & & $X$ & $\mathrm{Y}$ & $\mathrm{Z}$ \\
\hline 1 & 6 & 0 & 1.00480 & -0.46570 & 0.25430 \\
\hline 2 & 6 & 0 & 0.07150 & -0.57590 & 1.33130 \\
\hline 3 & 6 & 0 & 0.37090 & -1.19900 & 2.53750 \\
\hline 4 & 6 & 0 & 1.64970 & -1.75770 & 2.71410 \\
\hline 5 & 6 & 0 & 2.51950 & -1.75320 & 1.64450 \\
\hline 6 & 6 & 0 & 2.23260 & -1.12280 & 0.41960 \\
\hline 7 & 6 & 0 & 3.39710 & -1.28050 & -0.48220 \\
\hline 8 & 6 & 0 & 4.41160 & -1.96300 & 0.21660 \\
\hline 9 & 6 & 0 & 3.91420 & -2.28990 & 1.58710 \\
\hline 10 & 6 & 0 & 5.62770 & -2.27260 & -0.36150 \\
\hline 11 & 6 & 0 & 5.84470 & -1.89040 & -1.69040 \\
\hline 12 & 6 & 0 & 4.84060 & -1.23520 & -2.39950 \\
\hline 13 & 6 & 0 & 3.60560 & -0.92860 & -1.81120 \\
\hline 14 & 6 & 0 & -0.69960 & -1.31290 & 3.58930 \\
\hline 15 & 8 & 0 & 4.51660 & -2.86010 & 2.47310 \\
\hline 16 & 8 & 0 & -1.22390 & -0.21270 & 1.10670 \\
\hline 17 & 16 & 0 & 1.09260 & 0.97270 & -0.87350 \\
\hline 18 & 6 & 0 & 2.43570 & 1.97780 & -0.20230 \\
\hline 19 & 6 & 0 & 2.77460 & 1.96730 & 1.15140 \\
\hline 20 & 6 & 0 & 3.84840 & 2.74470 & 1.57680 \\
\hline 21 & 6 & 0 & 4.56640 & 3.51460 & 0.66250 \\
\hline 22 & 6 & 0 & 4.22170 & 3.50790 & -0.68740 \\
\hline 23 & 6 & 0 & 3.15680 & 2.72740 & -1.13020 \\
\hline
\end{tabular}




\begin{tabular}{|c|c|c|c|c|c|}
\hline 24 & 6 & 0 & -2.67830 & -1.56210 & -2.57170 \\
\hline 25 & 6 & 0 & -1.29080 & -1.41900 & -2.37260 \\
\hline 26 & 6 & 0 & -0.79610 & -0.94980 & -1.14680 \\
\hline 27 & 6 & 0 & -1.70020 & -0.66410 & -0.13880 \\
\hline 28 & 6 & 0 & -3.07100 & -0.76800 & -0.29660 \\
\hline 29 & 6 & 0 & -3.54000 & -1.22530 & -1.53920 \\
\hline 30 & 6 & 0 & -5.03220 & -1.26990 & -1.49050 \\
\hline 31 & 6 & 0 & -5.40180 & -0.79320 & -0.11550 \\
\hline 32 & 6 & 0 & -4.22420 & -0.49230 & 0.59160 \\
\hline 33 & 6 & 0 & -4.29760 & -0.01590 & 1.89250 \\
\hline 34 & 6 & 0 & -5.56600 & 0.14420 & 2.46790 \\
\hline 35 & 6 & 0 & -6.72970 & -0.16030 & 1.76320 \\
\hline 36 & 6 & 0 & -6.65410 & -0.63580 & 0.44830 \\
\hline 37 & 6 & 0 & -0.33520 & -1.72340 & -3.50380 \\
\hline 38 & 8 & 0 & -5.79540 & -1.61290 & -2.37080 \\
\hline 39 & 1 & 0 & 1.92570 & -2.22310 & 3.65600 \\
\hline 40 & 1 & 0 & 6.38710 & -2.80280 & 0.20630 \\
\hline 41 & 1 & 0 & 6.78980 & -2.11480 & -2.17420 \\
\hline 42 & 1 & 0 & 5.01110 & -0.96130 & -3.43630 \\
\hline 43 & 1 & 0 & 2.83490 & -0.44960 & -2.40770 \\
\hline 44 & 1 & 0 & -1.56600 & -1.85940 & 3.20170 \\
\hline 45 & 1 & 0 & -0.31840 & -1.84210 & 4.46570 \\
\hline 46 & 1 & 0 & -1.05510 & -0.32740 & 3.90730 \\
\hline 47 & 1 & 0 & 2.22190 & 1.35900 & 1.86150 \\
\hline 48 & 1 & 0 & 4.12490 & 2.74370 & 2.62620 \\
\hline 49 & 1 & 0 & 5.40320 & 4.11600 & 1.00360 \\
\hline 50 & 1 & 0 & 4.78610 & 4.10020 & -1.40020 \\
\hline 51 & 1 & 0 & 2.89270 & 2.70250 & -2.18430 \\
\hline 52 & 1 & 0 & -3.07560 & -1.91440 & -3.52190 \\
\hline 53 & 1 & 0 & -3.39890 & 0.23130 & 2.44850 \\
\hline 54 & 1 & 0 & -5.64240 & 0.51510 & 3.48590 \\
\hline 55 & 1 & 0 & -7.69710 & -0.02590 & 2.23670 \\
\hline 56 & 1 & 0 & -7.54980 & -0.87580 & -0.11810 \\
\hline 57 & 1 & 0 & 0.48990 & -2.35410 & -3.15760 \\
\hline 58 & 1 & 0 & -0.83560 & -2.23140 & -4.33380 \\
\hline 59 & 1 & 0 & 0.10980 & -0.79990 & -3.89590 \\
\hline 60 & 6 & 0 & -0.32540 & 2.02520 & -0.55560 \\
\hline 61 & 6 & 0 & -0.52760 & 2.63620 & 0.67940 \\
\hline 62 & 6 & 0 & -1.19190 & 2.22180 & -1.62820 \\
\hline 63 & 6 & 0 & -1.64340 & 3.44980 & 0.84240 \\
\hline 64 & 1 & 0 & 0.15880 & 2.47420 & 1.50460 \\
\hline 65 & 6 & 0 & -2.30100 & 3.04490 & -1.45100 \\
\hline 66 & 1 & 0 & -1.01350 & 1.72680 & -2.57800 \\
\hline 67 & 6 & 0 & -2.52760 & 3.65130 & -0.21800 \\
\hline 68 & 1 & 0 & -1.82220 & 3.92550 & 1.80110 \\
\hline 69 & 1 & 0 & -2.98720 & 3.20410 & -2.27610 \\
\hline 70 & 1 & 0 & -3.39660 & 4.28700 & -0.08080 \\
\hline
\end{tabular}




\section{Free Energy and Geometry for XVI-A}

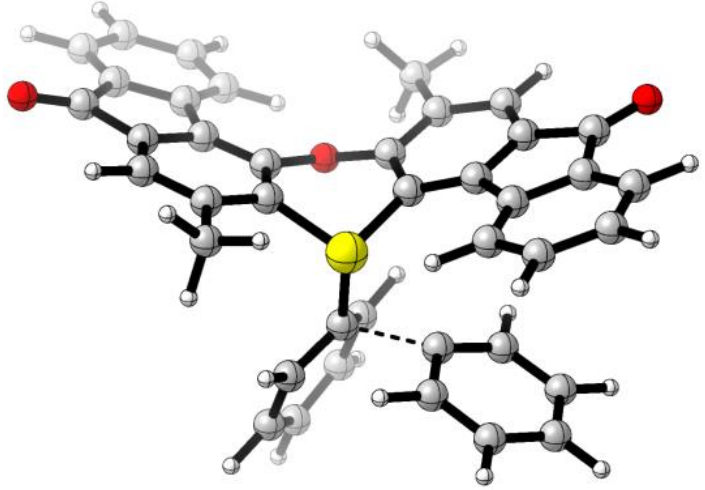

Sum of electronic and thermal free energies: -2162.462513 a.u.

$\mathrm{E}\left[\left(\mathrm{SMD}: \mathrm{C}_{2} \mathrm{H}_{4} \mathrm{Cl}_{2}\right) / \mathrm{M} 06-2 \mathrm{X} / 6-311+\mathrm{G}^{* *} / /\left(\mathrm{SMD}: \mathrm{C}_{2} \mathrm{H}_{4} \mathrm{Cl}_{2}\right) / \mathrm{M} 06-2 \mathrm{X} / 6-31 \mathrm{G}^{*}\right]=-2163.41993254$ a.u.

Number of imaginary frequencies: 1

\begin{tabular}{|c|c|c|c|c|c|}
\hline \multirow{2}{*}{$\begin{array}{l}\text { Center } \\
\text { Number }\end{array}$} & \multirow{2}{*}{$\begin{array}{l}\text { Atomic } \\
\text { Number }\end{array}$} & \multirow{2}{*}{$\begin{array}{c}\text { Atomic } \\
\text { Type }\end{array}$} & \multicolumn{3}{|c|}{ Coordinates (Ångstroms) } \\
\hline & & & $X$ & $\mathrm{Y}$ & $\mathrm{Z}$ \\
\hline 1 & 6 & 0 & -0.79450 & 0.76630 & -0.12580 \\
\hline 2 & 6 & 0 & 0.27020 & 1.46200 & 0.47730 \\
\hline 3 & 6 & 0 & 0.12330 & 2.75410 & 1.00330 \\
\hline 4 & 6 & 0 & -1.11890 & 3.36970 & 0.86290 \\
\hline 5 & 6 & 0 & -2.13560 & 2.72360 & 0.18140 \\
\hline 6 & 6 & 0 & -1.99980 & 1.43300 & -0.34470 \\
\hline 7 & 6 & 0 & -3.26280 & 1.07890 & -1.05930 \\
\hline 8 & 6 & 0 & -4.16690 & 2.14280 & -0.89680 \\
\hline 9 & 6 & 0 & -3.51220 & 3.22690 & -0.10930 \\
\hline 10 & 6 & 0 & -5.43510 & 2.12940 & -1.44800 \\
\hline 11 & 6 & 0 & -5.81190 & 1.01230 & -2.19840 \\
\hline 12 & 6 & 0 & -4.91370 & -0.03590 & -2.38980 \\
\hline 13 & 6 & 0 & -3.62950 & -0.01450 & -1.83140 \\
\hline 14 & 6 & 0 & 1.28480 & 3.43160 & 1.67220 \\
\hline 15 & 8 & 0 & -3.98290 & 4.29310 & 0.22220 \\
\hline 16 & 8 & 0 & 1.51570 & 0.91620 & 0.61010 \\
\hline 17 & 16 & 0 & -0.56220 & -0.93560 & -0.57790 \\
\hline 18 & 6 & 0 & -2.54150 & -1.56960 & 0.73680 \\
\hline 19 & 6 & 0 & -3.22250 & -0.81710 & 1.69230 \\
\hline 20 & 6 & 0 & -4.57380 & -1.04550 & 1.96250 \\
\hline 21 & 6 & 0 & -5.25680 & -2.06010 & 1.28980 \\
\hline 22 & 6 & 0 & -4.57730 & -2.84890 & 0.36030 \\
\hline 23 & 6 & 0 & -3.22870 & -2.59980 & 0.09720 \\
\hline 24 & 6 & 0 & 3.05160 & -1.53060 & -2.40340 \\
\hline
\end{tabular}




\begin{tabular}{|c|c|c|c|c|c|}
\hline 25 & 6 & 0 & 1.66640 & -1.53300 & -2.17410 \\
\hline 26 & 6 & 0 & 1.16820 & -0.72430 & -1.14350 \\
\hline 27 & 6 & 0 & 2.00600 & 0.07710 & -0.35880 \\
\hline 28 & 6 & 0 & 3.37460 & 0.04270 & -0.55940 \\
\hline 29 & 6 & 0 & 3.86560 & -0.76520 & -1.59330 \\
\hline 30 & 6 & 0 & 5.36040 & -0.60280 & -1.64430 \\
\hline 31 & 6 & 0 & 5.69160 & 0.35300 & -0.54390 \\
\hline 32 & 6 & 0 & 4.50470 & 0.73100 & 0.10770 \\
\hline 33 & 6 & 0 & 4.55010 & 1.59110 & 1.19450 \\
\hline 34 & 6 & 0 & 5.80100 & 2.07600 & 1.59920 \\
\hline 35 & 6 & 0 & 6.97400 & 1.70810 & 0.94140 \\
\hline 36 & 6 & 0 & 6.92800 & 0.82880 & -0.14570 \\
\hline 37 & 6 & 0 & 0.78020 & -2.42940 & -3.00150 \\
\hline 38 & 8 & 0 & 6.12170 & -1.13870 & -2.41840 \\
\hline 39 & 1 & 0 & -1.27830 & 4.36890 & 1.26010 \\
\hline 40 & 1 & 0 & -6.10830 & 2.96860 & -1.29930 \\
\hline 41 & 1 & 0 & -6.80140 & 0.96300 & -2.64120 \\
\hline 42 & 1 & 0 & -5.21180 & -0.89360 & -2.98520 \\
\hline 43 & 1 & 0 & -2.95810 & -0.84650 & -2.00510 \\
\hline 44 & 1 & 0 & 0.98270 & 4.41140 & 2.04800 \\
\hline 45 & 1 & 0 & 1.65600 & 2.83790 & 2.51390 \\
\hline 46 & 1 & 0 & 2.11620 & 3.56560 & 0.97210 \\
\hline 47 & 1 & 0 & -2.70070 & -0.02630 & 2.23730 \\
\hline 48 & 1 & 0 & -5.09650 & -0.43580 & 2.69640 \\
\hline 49 & 1 & 0 & -6.30750 & -2.24230 & 1.49760 \\
\hline 50 & 1 & 0 & -5.10070 & -3.65020 & -0.15690 \\
\hline 51 & 1 & 0 & -2.71040 & -3.22390 & -0.63770 \\
\hline 52 & 1 & 0 & 3.47530 & -2.13350 & -3.20210 \\
\hline 53 & 1 & 0 & 3.64890 & 1.87470 & 1.72650 \\
\hline 54 & 1 & 0 & 5.85570 & 2.75120 & 2.44780 \\
\hline 55 & 1 & 0 & 7.92710 & 2.10120 & 1.28000 \\
\hline 56 & 1 & 0 & 7.83180 & 0.52270 & -0.66460 \\
\hline 57 & 1 & 0 & -0.24020 & -2.04910 & -3.08670 \\
\hline 58 & 1 & 0 & 1.18680 & -2.52250 & -4.01170 \\
\hline 59 & 1 & 0 & 0.73260 & -3.43390 & -2.56600 \\
\hline 60 & 6 & 0 & -0.42170 & -1.84390 & 0.97950 \\
\hline 61 & 6 & 0 & -0.10160 & -3.21560 & 0.78650 \\
\hline 62 & 6 & 0 & -0.04620 & -1.23160 & 2.20040 \\
\hline 63 & 6 & 0 & 0.31050 & -3.98070 & 1.86620 \\
\hline 64 & 1 & 0 & -0.23540 & -3.67370 & -0.18990 \\
\hline 65 & 6 & 0 & 0.37930 & -2.02710 & 3.25530 \\
\hline 66 & 1 & 0 & -0.18010 & -0.16580 & 2.34980 \\
\hline 67 & 6 & 0 & 0.54300 & -3.40700 & 3.11860 \\
\hline 68 & 1 & 0 & 0.48890 & -5.04180 & 1.71230 \\
\hline 69 & 1 & 0 & 0.60300 & -1.54650 & 4.20430 \\
\hline 70 & 1 & 0 & 0.88780 & -4.01050 & 3.95100 \\
\hline
\end{tabular}




\section{Free Energy and Geometry for XVII-B}

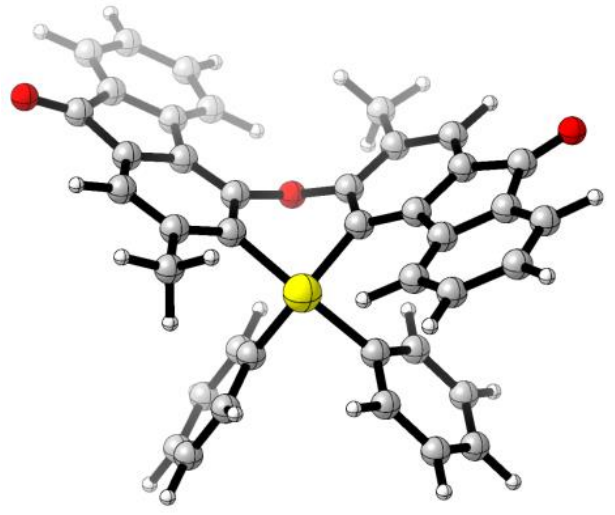

Sum of electronic and thermal free energies: -2162.481712 a.u.

$\mathrm{E}\left[\left(\mathrm{SMD}: \mathrm{C}_{2} \mathrm{H}_{4} \mathrm{Cl}_{2}\right) / \mathrm{M} 06-2 \mathrm{X} / 6-311+\mathrm{G}^{* *} / /\left(\mathrm{SMD}: \mathrm{C}_{2} \mathrm{H}_{4} \mathrm{Cl}_{2}\right) / \mathrm{M} 06-2 \mathrm{X} / 6-31 \mathrm{G}^{*}\right]=-2163.43871213$ a.u.

Number of imaginary frequencies: 1

\begin{tabular}{|c|c|c|c|c|c|}
\hline \multirow{2}{*}{$\begin{array}{l}\text { Center } \\
\text { Number }\end{array}$} & \multirow{2}{*}{$\begin{array}{l}\text { Atomic } \\
\text { Number }\end{array}$} & \multirow{2}{*}{$\begin{array}{l}\text { Atomic } \\
\text { Type }\end{array}$} & \multicolumn{3}{|c|}{ Coordinates (Ångstroms) } \\
\hline & & & $X$ & $\mathrm{Y}$ & $\mathrm{Z}$ \\
\hline 1 & 6 & 0 & -0.93770 & -0.76540 & -0.04180 \\
\hline 2 & 6 & 0 & 0.08460 & -1.39510 & -0.76690 \\
\hline 3 & 6 & 0 & -0.04480 & -2.67380 & -1.32780 \\
\hline 4 & 6 & 0 & -1.23860 & -3.36030 & -1.10220 \\
\hline 5 & 6 & 0 & -2.21680 & -2.78250 & -0.31200 \\
\hline 6 & 6 & 0 & -2.08830 & -1.49750 & 0.23550 \\
\hline 7 & 6 & 0 & -3.30760 & -1.20750 & 1.04550 \\
\hline 8 & 6 & 0 & -4.18050 & -2.30390 & 0.93440 \\
\hline 9 & 6 & 0 & -3.54500 & -3.34650 & 0.07320 \\
\hline 10 & 6 & 0 & -5.39590 & -2.35240 & 1.59110 \\
\hline 11 & 6 & 0 & -5.75080 & -1.26640 & 2.39780 \\
\hline 12 & 6 & 0 & -4.88170 & -0.18650 & 2.53750 \\
\hline 13 & 6 & 0 & -3.65050 & -0.14480 & 1.86950 \\
\hline 14 & 6 & 0 & 1.08520 & -3.27500 & -2.11430 \\
\hline 15 & 8 & 0 & -4.00470 & -4.42250 & -0.24470 \\
\hline 16 & 8 & 0 & 1.29280 & -0.76180 & -0.96270 \\
\hline 17 & 16 & 0 & -0.79080 & 1.03470 & 0.35130 \\
\hline 18 & 6 & 0 & -2.29910 & 1.34270 & -0.83790 \\
\hline 19 & 6 & 0 & -2.37190 & 0.81180 & -2.12540 \\
\hline 20 & 6 & 0 & -3.44580 & 1.12950 & -2.95650 \\
\hline 21 & 6 & 0 & -4.45760 & 1.97430 & -2.50200 \\
\hline 22 & 6 & 0 & -4.38730 & 2.50640 & -1.21630 \\
\hline 23 & 6 & 0 & -3.30720 & 2.19560 & -0.38950 \\
\hline
\end{tabular}




\begin{tabular}{|c|c|c|c|c|c|}
\hline 24 & 6 & 0 & 2.83750 & 1.01010 & 2.48680 \\
\hline 25 & 6 & 0 & 1.48700 & 1.21060 & 2.15620 \\
\hline 26 & 6 & 0 & 0.99220 & 0.64840 & 0.97120 \\
\hline 27 & 6 & 0 & 1.81650 & -0.12840 & 0.15290 \\
\hline 28 & 6 & 0 & 3.16260 & -0.27630 & 0.43690 \\
\hline 29 & 6 & 0 & 3.64650 & 0.29980 & 1.62050 \\
\hline 30 & 6 & 0 & 5.10110 & -0.03670 & 1.74780 \\
\hline 31 & 6 & 0 & 5.43180 & -0.83510 & 0.52480 \\
\hline 32 & 6 & 0 & 4.27360 & -0.96710 & -0.26100 \\
\hline 33 & 6 & 0 & 4.33180 & -1.63090 & -1.47740 \\
\hline 34 & 6 & 0 & 5.56020 & -2.17650 & -1.87480 \\
\hline 35 & 6 & 0 & 6.70140 & -2.05620 & -1.08330 \\
\hline 36 & 6 & 0 & 6.64570 & -1.37040 & 0.13530 \\
\hline 37 & 6 & 0 & 0.60270 & 2.01950 & 3.07020 \\
\hline 38 & 8 & 0 & 5.84970 & 0.27280 & 2.64980 \\
\hline 39 & 1 & 0 & -1.38630 & -4.35250 & -1.52070 \\
\hline 40 & 1 & 0 & -6.04580 & -3.21610 & 1.48330 \\
\hline 41 & 1 & 0 & -6.69850 & -1.26870 & 2.92670 \\
\hline 42 & 1 & 0 & -5.15960 & 0.64270 & 3.18110 \\
\hline 43 & 1 & 0 & -2.98710 & 0.70030 & 2.01480 \\
\hline 44 & 1 & 0 & 0.77490 & -4.22610 & -2.55310 \\
\hline 45 & 1 & 0 & 1.40800 & -2.60970 & -2.92110 \\
\hline 46 & 1 & 0 & 1.95260 & -3.45910 & -1.47110 \\
\hline 47 & 1 & 0 & -1.59560 & 0.14130 & -2.49000 \\
\hline 48 & 1 & 0 & -3.49230 & 0.71500 & -3.95970 \\
\hline 49 & 1 & 0 & -5.29710 & 2.21570 & -3.14700 \\
\hline 50 & 1 & 0 & -5.17470 & 3.16090 & -0.85300 \\
\hline 51 & 1 & 0 & -3.25810 & 2.62100 & 0.61130 \\
\hline 52 & 1 & 0 & 3.24580 & 1.42180 & 3.40650 \\
\hline 53 & 1 & 0 & 3.45640 & -1.71860 & -2.11120 \\
\hline 54 & 1 & 0 & 5.62300 & -2.70110 & -2.82350 \\
\hline 55 & 1 & 0 & 7.63780 & -2.49010 & -1.41890 \\
\hline 56 & 1 & 0 & 7.52660 & -1.25480 & 0.76050 \\
\hline 57 & 1 & 0 & -0.28140 & 1.45030 & 3.37560 \\
\hline 58 & 1 & 0 & 1.14950 & 2.30810 & 3.97130 \\
\hline 59 & 1 & 0 & 0.25510 & 2.93580 & 2.58130 \\
\hline 60 & 6 & 0 & -0.07250 & 2.59940 & -0.36540 \\
\hline 61 & 6 & 0 & -0.47080 & 3.82160 & 0.17400 \\
\hline 62 & 6 & 0 & 0.81470 & 2.54920 & -1.43900 \\
\hline 63 & 6 & 0 & 0.04310 & 5.00410 & -0.35960 \\
\hline 64 & 1 & 0 & -1.17570 & 3.85910 & 0.99950 \\
\hline 65 & 6 & 0 & 1.31360 & 3.73610 & -1.97040 \\
\hline 66 & 1 & 0 & 1.11650 & 1.59440 & -1.86180 \\
\hline 67 & 6 & 0 & 0.93290 & 4.96380 & -1.42980 \\
\hline 68 & 1 & 0 & -0.25760 & 5.95670 & 0.06630 \\
\hline 69 & 1 & 0 & 2.00200 & 3.69930 & -2.80950 \\
\hline 70 & 1 & 0 & 1.32760 & 5.88630 & -1.84420 \\
\hline
\end{tabular}




\section{Free Energy and Geometry for XVI-B}

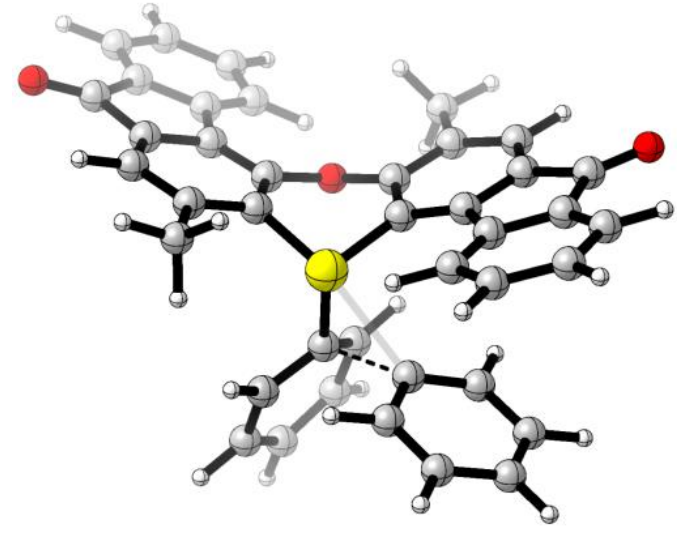

Sum of electronic and thermal free energies: -2162.462433 a.u.

$\mathrm{E}\left[\left(\mathrm{SMD}: \mathrm{C}_{2} \mathrm{H}_{4} \mathrm{Cl}_{2}\right) / \mathrm{M} 06-2 \mathrm{X} / 6-311+\mathrm{G}^{* *} / /\left(\mathrm{SMD}: \mathrm{C}_{2} \mathrm{H}_{4} \mathrm{Cl}_{2}\right) / \mathrm{M} 06-2 \mathrm{X} / 6-31 \mathrm{G}^{*}\right]=-2163.42053821$ a.u.

Number of imaginary frequencies: 1

\begin{tabular}{|c|c|c|c|c|c|}
\hline \multirow{2}{*}{$\begin{array}{l}\text { Center } \\
\text { Number }\end{array}$} & \multirow{2}{*}{$\begin{array}{l}\text { Atomic } \\
\text { Number }\end{array}$} & \multirow{2}{*}{$\begin{array}{c}\text { Atomic } \\
\text { Type }\end{array}$} & \multicolumn{3}{|c|}{ Coordinates (Ångstroms) } \\
\hline & & & $\mathrm{X}$ & $\mathrm{Y}$ & $\mathrm{Z}$ \\
\hline 1 & 6 & 0 & -0.78280 & 0.76090 & -0.11210 \\
\hline 2 & 6 & 0 & 0.28360 & 1.44610 & 0.50120 \\
\hline 3 & 6 & 0 & 0.14060 & 2.73450 & 1.03700 \\
\hline 4 & 6 & 0 & -1.09780 & 3.35810 & 0.89550 \\
\hline 5 & 6 & 0 & -2.11440 & 2.72350 & 0.20330 \\
\hline 6 & 6 & 0 & -1.98260 & 1.43650 & -0.33270 \\
\hline 7 & 6 & 0 & -3.24220 & 1.09560 & -1.05900 \\
\hline 8 & 6 & 0 & -4.14210 & 2.16230 & -0.89240 \\
\hline 9 & 6 & 0 & -3.48690 & 3.23610 & -0.09110 \\
\hline 10 & 6 & 0 & -5.40630 & 2.16060 & -1.45290 \\
\hline 11 & 6 & 0 & -5.78300 & 1.05280 & -2.21690 \\
\hline 12 & 6 & 0 & -4.88830 & 0.00230 & -2.41290 \\
\hline 13 & 6 & 0 & -3.60800 & 0.01190 & -1.84520 \\
\hline 14 & 6 & 0 & 1.30210 & 3.40140 & 1.71650 \\
\hline 15 & 8 & 0 & -3.95440 & 4.30160 & 0.24720 \\
\hline 16 & 8 & 0 & 1.52610 & 0.89230 & 0.63530 \\
\hline 17 & 16 & 0 & -0.56190 & -0.94190 & -0.56750 \\
\hline 18 & 6 & 0 & -2.55640 & -1.57040 & 0.72130 \\
\hline 19 & 6 & 0 & -3.25110 & -0.82480 & 1.67230 \\
\hline 20 & 6 & 0 & -4.60790 & -1.05040 & 1.91610 \\
\hline 21 & 6 & 0 & -5.28230 & -2.05640 & 1.22190 \\
\hline 22 & 6 & 0 & -4.58930 & -2.83890 & 0.29700 \\
\hline 23 & 6 & 0 & -3.23550 & -2.59200 & 0.05980 \\
\hline
\end{tabular}




\begin{tabular}{|c|c|c|c|c|c|}
\hline 24 & 6 & 0 & 3.03650 & -1.52490 & -2.41710 \\
\hline 25 & 6 & 0 & 1.65660 & -1.53220 & -2.17100 \\
\hline 26 & 6 & 0 & 1.17010 & -0.73390 & -1.12530 \\
\hline 27 & 6 & 0 & 2.01180 & 0.05920 & -0.34120 \\
\hline 28 & 6 & 0 & 3.37980 & 0.02730 & -0.55670 \\
\hline 29 & 6 & 0 & 3.85930 & -0.76730 & -1.60460 \\
\hline 30 & 6 & 0 & 5.35300 & -0.60190 & -1.67130 \\
\hline 31 & 6 & 0 & 5.69600 & 0.34270 & -0.56460 \\
\hline 32 & 6 & 0 & 4.51620 & 0.71070 & 0.10520 \\
\hline 33 & 6 & 0 & 4.57240 & 1.55790 & 1.20130 \\
\hline 34 & 6 & 0 & 5.82690 & 2.04150 & 1.59670 \\
\hline 35 & 6 & 0 & 6.99260 & 1.68400 & 0.92080 \\
\hline 36 & 6 & 0 & 6.93580 & 0.81680 & -0.17570 \\
\hline 37 & 6 & 0 & 0.73490 & -2.38290 & -3.00750 \\
\hline 38 & 8 & 0 & 6.10590 & -1.12780 & -2.46030 \\
\hline 39 & 1 & 0 & -1.25360 & 4.35490 & 1.29980 \\
\hline 40 & 1 & 0 & -6.07650 & 3.00160 & -1.30080 \\
\hline 41 & 1 & 0 & -6.76950 & 1.01270 & -2.66740 \\
\hline 42 & 1 & 0 & -5.18620 & -0.84760 & -3.01930 \\
\hline 43 & 1 & 0 & -2.93880 & -0.82100 & -2.02320 \\
\hline 44 & 1 & 0 & 1.01340 & 4.39500 & 2.06540 \\
\hline 45 & 1 & 0 & 1.64360 & 2.81760 & 2.57770 \\
\hline 46 & 1 & 0 & 2.14990 & 3.50410 & 1.03120 \\
\hline 47 & 1 & 0 & -2.73610 & -0.04110 & 2.23360 \\
\hline 48 & 1 & 0 & -5.14140 & -0.44580 & 2.64630 \\
\hline 49 & 1 & 0 & -6.33710 & -2.23660 & 1.40940 \\
\hline 50 & 1 & 0 & -5.10640 & -3.63320 & -0.23700 \\
\hline 51 & 1 & 0 & -2.70690 & -3.20920 & -0.67360 \\
\hline 52 & 1 & 0 & 3.45330 & -2.11670 & -3.22730 \\
\hline 53 & 1 & 0 & 3.67680 & 1.83240 & 1.74740 \\
\hline 54 & 1 & 0 & 5.89000 & 2.70700 & 2.45240 \\
\hline 55 & 1 & 0 & 7.94880 & 2.07560 & 1.25250 \\
\hline 56 & 1 & 0 & 7.83420 & 0.51870 & -0.70850 \\
\hline 57 & 1 & 0 & -0.09420 & -1.79670 & -3.41630 \\
\hline 58 & 1 & 0 & 1.28550 & -2.82290 & -3.84150 \\
\hline 59 & 1 & 0 & 0.30490 & -3.20330 & -2.42180 \\
\hline 60 & 6 & 0 & -0.43930 & -1.84710 & 0.99630 \\
\hline 61 & 6 & 0 & -0.11900 & -3.22000 & 0.81560 \\
\hline 62 & 6 & 0 & -0.08000 & -1.22940 & 2.21920 \\
\hline 63 & 6 & 0 & 0.28150 & -3.97930 & 1.90370 \\
\hline 64 & 1 & 0 & -0.24270 & -3.68520 & -0.15840 \\
\hline 65 & 6 & 0 & 0.33410 & -2.01900 & 3.28310 \\
\hline 66 & 1 & 0 & -0.21650 & -0.16310 & 2.36240 \\
\hline 67 & 6 & 0 & 0.50050 & -3.39920 & 3.15550 \\
\hline 68 & 1 & 0 & 0.46120 & -5.04130 & 1.75720 \\
\hline 69 & 1 & 0 & 0.54600 & -1.53310 & 4.23210 \\
\hline 70 & 1 & 0 & 0.83610 & -3.99830 & 3.99480 \\
\hline
\end{tabular}




\section{Free Energy and Geometry for the S-dibenzofuran 27}

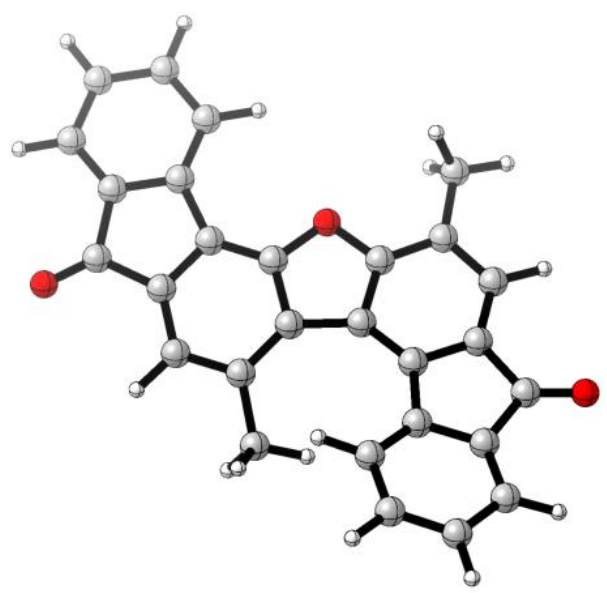

Sum of electronic and thermal free energies: -1301.531754 a.u.

$\mathrm{E}\left[\left(\mathrm{SMD}: \mathrm{C}_{2} \mathrm{H}_{4} \mathrm{Cl}_{2}\right) / \mathrm{M} 06-2 \mathrm{X} / 6-311+\mathrm{G}^{* *} / /\left(\mathrm{SMD}: \mathrm{C}_{2} \mathrm{H}_{4} \mathrm{Cl}_{2}\right) / \mathrm{M} 06-2 \mathrm{X} / 6-31 \mathrm{G}^{*}\right]=-1302.16799670$ a.u.

Number of imaginary frequencies: 0

\begin{tabular}{|c|c|c|c|c|c|}
\hline \multirow{2}{*}{$\begin{array}{l}\text { Center } \\
\text { Number }\end{array}$} & \multirow{2}{*}{$\begin{array}{l}\text { Atomic } \\
\text { Number }\end{array}$} & \multirow{2}{*}{$\begin{array}{l}\text { Atomic } \\
\text { Type }\end{array}$} & \multicolumn{3}{|c|}{ Coordinates (Angstroms) } \\
\hline & & & $\mathrm{X}$ & $\mathrm{Y}$ & $\mathrm{Z}$ \\
\hline 1 & 6 & 0 & -1.02320 & 0.36860 & 0.15330 \\
\hline 2 & 6 & 0 & -0.43860 & 1.65550 & 0.09810 \\
\hline 3 & 6 & 0 & -1.10020 & 2.87900 & 0.16710 \\
\hline 4 & 6 & 0 & -2.48700 & 2.79500 & 0.28220 \\
\hline 5 & 6 & 0 & -3.10950 & 1.55300 & 0.22430 \\
\hline 6 & 6 & 0 & -2.42360 & 0.33410 & 0.09020 \\
\hline 7 & 6 & 0 & -3.43020 & -0.72730 & -0.19940 \\
\hline 8 & 6 & 0 & -4.71510 & -0.17410 & -0.05480 \\
\hline 9 & 6 & 0 & -4.57800 & 1.28660 & 0.23000 \\
\hline 10 & 6 & 0 & -5.86490 & -0.89860 & -0.30530 \\
\hline 11 & 6 & 0 & -5.72820 & -2.22150 & -0.74100 \\
\hline 12 & 6 & 0 & -4.46040 & -2.75640 & -0.95720 \\
\hline 13 & 6 & 0 & -3.29960 & -2.01340 & -0.70190 \\
\hline 14 & 6 & 0 & -0.33700 & 4.17130 & 0.12750 \\
\hline 15 & 8 & 0 & -5.46950 & 2.09200 & 0.39730 \\
\hline 16 & 8 & 0 & 0.91890 & 1.58620 & -0.02100 \\
\hline 17 & 6 & 0 & 1.59530 & -2.43260 & 0.49190 \\
\hline 18 & 6 & 0 & 0.28910 & -1.92030 & 0.54350 \\
\hline 19 & 6 & 0 & 0.10990 & -0.56150 & 0.21730 \\
\hline 20 & 6 & 0 & 1.24610 & 0.26410 & 0.03860 \\
\hline 21 & 6 & 0 & 2.53020 & -0.22810 & -0.00480 \\
\hline 22 & 6 & 0 & 2.66800 & -1.60780 & 0.19620 \\
\hline
\end{tabular}




\begin{tabular}{|c|c|c|c|c|c|}
\hline 23 & 6 & 0 & 4.13070 & -1.93880 & 0.13930 \\
\hline 24 & 6 & 0 & 4.82440 & -0.63310 & -0.10690 \\
\hline 25 & 6 & 0 & 3.86200 & 0.38780 & -0.18630 \\
\hline 26 & 6 & 0 & 4.24760 & 1.70100 & -0.40500 \\
\hline 27 & 6 & 0 & 5.61610 & 1.96920 & -0.54320 \\
\hline 28 & 6 & 0 & 6.56860 & 0.95380 & -0.46460 \\
\hline 29 & 6 & 0 & 6.17540 & -0.37110 & -0.24310 \\
\hline 30 & 6 & 0 & -0.80290 & -2.80630 & 1.08100 \\
\hline 31 & 8 & 0 & 4.64040 & -3.03030 & 0.27170 \\
\hline 32 & 1 & 0 & -3.08590 & 3.69790 & 0.37080 \\
\hline 33 & 1 & 0 & -6.84190 & -0.43840 & -0.18820 \\
\hline 34 & 1 & 0 & -6.60970 & -2.82060 & -0.94570 \\
\hline 35 & 1 & 0 & -4.36490 & -3.76650 & -1.34390 \\
\hline 36 & 1 & 0 & -2.32680 & -2.43200 & -0.92880 \\
\hline 37 & 1 & 0 & -1.01770 & 5.01950 & 0.22690 \\
\hline 38 & 1 & 0 & 0.39880 & 4.21820 & 0.93710 \\
\hline 39 & 1 & 0 & 0.20950 & 4.27440 & -0.81600 \\
\hline 40 & 1 & 0 & 1.76870 & -3.47860 & 0.73310 \\
\hline 41 & 1 & 0 & 3.51660 & 2.50090 & -0.46870 \\
\hline 42 & 1 & 0 & 5.94010 & 2.99120 & -0.71510 \\
\hline 43 & 1 & 0 & 7.62110 & 1.19440 & -0.57550 \\
\hline 44 & 1 & 0 & 6.90420 & -1.17400 & -0.17780 \\
\hline 45 & 1 & 0 & -1.69250 & -2.23870 & 1.35730 \\
\hline 46 & 1 & 0 & -1.09290 & -3.58600 & 0.36940 \\
\hline 47 & 1 & 0 & -0.43500 & -3.31420 & 1.97790 \\
\hline
\end{tabular}




\section{Free Energy and Geometry for $\mathrm{Ph}_{2} \mathrm{~S}$}

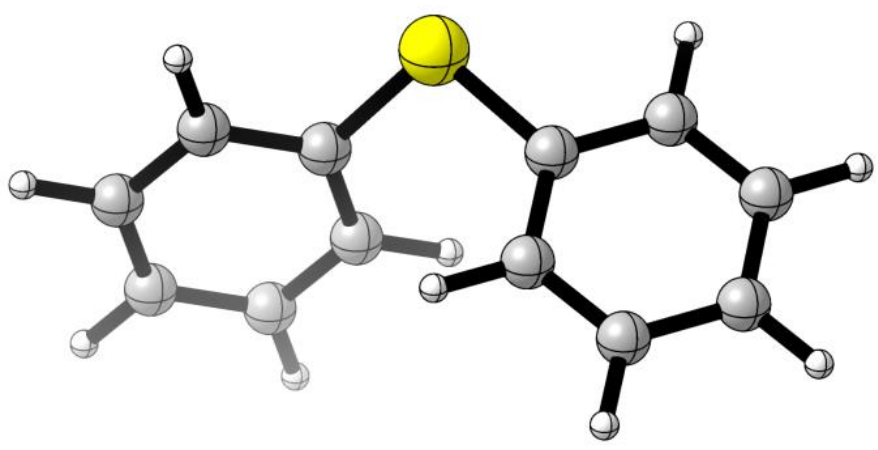

Sum of electronic and thermal free energies: -861.116682 a.u.

$\mathrm{E}\left[\left(\mathrm{SMD}: \mathrm{C}_{2} \mathrm{H}_{4} \mathrm{Cl}_{2}\right) / \mathrm{M} 06-2 \mathrm{X} / 6-311+\mathrm{G}^{* *} / /\left(\mathrm{SMD}: \mathrm{C}_{2} \mathrm{H}_{4} \mathrm{Cl}_{2}\right) / \mathrm{M} 06-2 \mathrm{X} / 6-31 \mathrm{G}^{*}\right]=-861.411557127$ a.u.

Number of imaginary frequencies: 0

\begin{tabular}{|c|c|c|c|c|c|}
\hline \multirow{2}{*}{$\begin{array}{l}\text { Center } \\
\text { Number }\end{array}$} & \multirow{2}{*}{$\begin{array}{l}\text { Atomic } \\
\text { Number }\end{array}$} & \multirow{2}{*}{$\begin{array}{c}\text { Atomic } \\
\text { Type }\end{array}$} & \multicolumn{3}{|c|}{ Coordinates (Ångstroms) } \\
\hline & & & $X$ & $\mathrm{Y}$ & $\mathrm{Z}$ \\
\hline 1 & 16 & 0 & -0.00000 & 0.00000 & 1.65090 \\
\hline 2 & 6 & 0 & -0.30070 & -1.35880 & 0.53120 \\
\hline 3 & 6 & 0 & 0.30070 & 1.35880 & 0.53120 \\
\hline 4 & 6 & 0 & 1.13760 & 1.21980 & -0.58060 \\
\hline 5 & 6 & 0 & 1.38440 & 2.31640 & -1.40000 \\
\hline 6 & 6 & 0 & 0.82170 & 3.55870 & -1.10500 \\
\hline 7 & 6 & 0 & 0.00000 & 3.69720 & 0.01020 \\
\hline 8 & 6 & 0 & -0.27070 & 2.59810 & 0.82450 \\
\hline 9 & 6 & 0 & 0.27070 & -2.59810 & 0.82450 \\
\hline 10 & 6 & 0 & -0.00000 & -3.69720 & 0.01020 \\
\hline 11 & 6 & 0 & -0.82170 & -3.55870 & -1.10500 \\
\hline 12 & 6 & 0 & -1.38440 & -2.31640 & -1.40000 \\
\hline 13 & 6 & 0 & -1.13760 & -1.21980 & -0.58060 \\
\hline 14 & 1 & 0 & 1.58700 & 0.25640 & -0.80480 \\
\hline 15 & 1 & 0 & 2.02910 & 2.20200 & -2.26640 \\
\hline 16 & 1 & 0 & 1.02250 & 4.41300 & -1.74390 \\
\hline 17 & 1 & 0 & -0.44610 & 4.65900 & 0.24460 \\
\hline 18 & 1 & 0 & -0.92950 & 2.70220 & 1.68180 \\
\hline 19 & 1 & 0 & 0.92950 & -2.70220 & 1.68180 \\
\hline 20 & 1 & 0 & 0.44610 & -4.65900 & 0.24460 \\
\hline 21 & 1 & 0 & -1.02250 & -4.41300 & -1.74390 \\
\hline 22 & 1 & 0 & -2.02910 & -2.20200 & -2.26640 \\
\hline 23 & 1 & 0 & -1.58700 & -0.25640 & -0.80480 \\
\hline
\end{tabular}


Free Energy and Geometry for the S-phenoxathiine 26

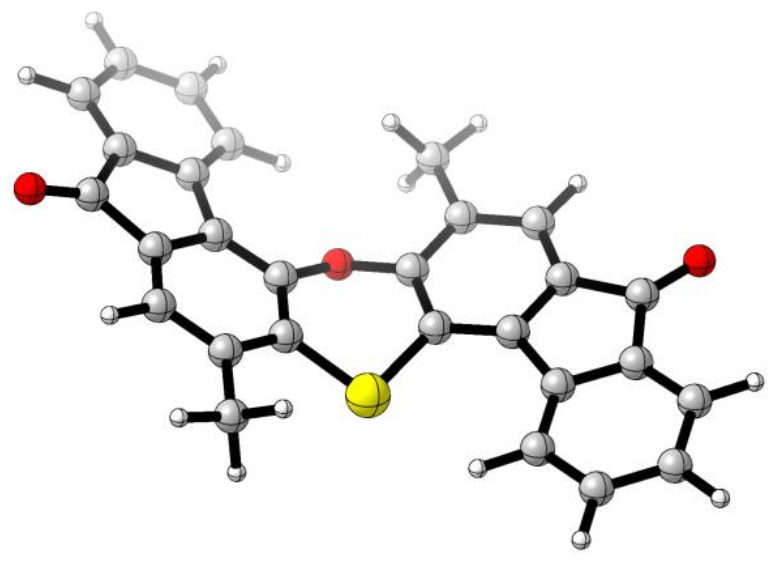

Sum of electronic and thermal free energies: -1699.685999 a.u.

$\mathrm{E}\left[\left(\mathrm{SMD}: \mathrm{C}_{2} \mathrm{H}_{4} \mathrm{Cl}_{2}\right) / \mathrm{M} 06-2 \mathrm{X} / 6-311+\mathrm{G}^{* *} / /\left(\mathrm{SMD}: \mathrm{C}_{2} \mathrm{H}_{4} \mathrm{Cl}_{2}\right) / \mathrm{M} 06-2 \mathrm{X} / 6-31 \mathrm{G}^{*}\right]=-1700.35168526$ a.u.

Number of imaginary frequencies: 0

\begin{tabular}{|c|c|c|c|c|c|}
\hline \multirow{2}{*}{$\begin{array}{l}\text { Center } \\
\text { Number }\end{array}$} & \multirow{2}{*}{$\begin{array}{l}\text { Atomic } \\
\text { Number }\end{array}$} & \multirow{2}{*}{$\begin{array}{c}\text { Atomic } \\
\text { Type }\end{array}$} & \multicolumn{3}{|c|}{ Coordinates (Ångstroms) } \\
\hline & & & $X$ & $\mathrm{Y}$ & Z \\
\hline 1 & 16 & 0 & 0.99680 & 1.58420 & 0.96320 \\
\hline 2 & 6 & 0 & -0.68480 & 1.59650 & 0.40320 \\
\hline 3 & 6 & 0 & -1.41190 & 0.39690 & 0.43840 \\
\hline 4 & 8 & 0 & -0.84120 & -0.78880 & 0.84130 \\
\hline 5 & 6 & 0 & 0.45740 & -1.06870 & 0.47400 \\
\hline 6 & 6 & 0 & 1.43490 & -0.06040 & 0.46850 \\
\hline 7 & 6 & 0 & 0.73480 & -2.40130 & 0.15410 \\
\hline 8 & 6 & 0 & 2.05500 & -2.73350 & -0.16800 \\
\hline 9 & 6 & 0 & 3.02050 & -1.74700 & -0.17930 \\
\hline 10 & 6 & 0 & 2.73650 & -0.40600 & 0.12490 \\
\hline 11 & 6 & 0 & -1.27070 & 2.80750 & 0.00530 \\
\hline 12 & 6 & 0 & -2.62430 & 2.80240 & -0.35950 \\
\hline 13 & 6 & 0 & -3.33320 & 1.62000 & -0.30220 \\
\hline 14 & 6 & 0 & -2.75310 & 0.40750 & 0.09970 \\
\hline 15 & 6 & 0 & -3.78890 & -0.65470 & 0.08560 \\
\hline 16 & 6 & 0 & -4.99110 & -0.08600 & -0.37050 \\
\hline 17 & 6 & 0 & -4.77170 & 1.36900 & -0.63790 \\
\hline 18 & 6 & 0 & 3.99560 & 0.38480 & 0.00940 \\
\hline 19 & 6 & 0 & 5.02800 & -0.49360 & -0.36810 \\
\hline 20 & 6 & 0 & 4.47240 & -1.87400 & -0.50360 \\
\hline 21 & 6 & 0 & 6.32810 & -0.06850 & -0.56480 \\
\hline 22 & 6 & 0 & 6.61240 & 1.28830 & -0.37800 \\
\hline 23 & 6 & 0 & 5.59940 & 2.16760 & -0.00380 \\
\hline
\end{tabular}




$\begin{array}{rrrrrr}24 & 6 & 0 & 4.28230 & 1.73070 & 0.19630 \\ 25 & 6 & 0 & -6.15320 & -0.82600 & -0.49050 \\ 26 & 6 & 0 & -6.11050 & -2.17890 & -0.13690 \\ 27 & 6 & 0 & -4.92660 & -2.74450 & 0.33360 \\ 28 & 6 & 0 & -3.75130 & -1.99070 & 0.45550 \\ 29 & 6 & 0 & -0.35790 & -3.43180 & 0.16830 \\ 30 & 6 & 0 & -0.47230 & 4.08220 & -0.01380 \\ 31 & 8 & 0 & -5.58090 & 2.17830 & -1.03680 \\ 32 & 8 & 0 & 5.06980 & -2.88290 & -0.81230 \\ 33 & 1 & 0 & 2.31370 & -3.75980 & -0.41460 \\ 34 & 1 & 0 & -3.10750 & 3.72280 & -0.67570 \\ 35 & 1 & 0 & 7.09950 & -0.77550 & -0.85630 \\ 36 & 1 & 0 & 7.62250 & 1.65760 & -0.52290 \\ 37 & 1 & 5.83050 & 3.21870 & 0.13940 \\ 38 & 1 & 0 & 3.52280 & 2.44720 & 0.48630 \\ 39 & 1 & 0 & -7.06900 & -0.36160 & -0.84490 \\ 40 & 1 & 0 & -7.00400 & -2.78940 & -0.21930 \\ 41 & 1 & 0 & -4.91280 & -3.79240 & 0.61780 \\ 42 & 1 & -2.84490 & -2.44130 & 0.84150 \\ 43 & 0 & 0.04250 & -4.40880 & -0.11090 \\ 44 & 0 & -0.81060 & -3.51610 & 1.16190 \\ 45 & 1 & 0 & -1.15390 & -3.16850 & -0.53590 \\ 46 & 1 & -1.08110 & 4.90550 & -0.39330 \\ 47 & 1 & -0.12660 & 4.35420 & 0.99030 \\ 48 & 1 & 0 & 0.41410 & 3.98320 & -0.64990 \\ ------------------------------------------------------------------------------------------------ \\ \end{array}$




\section{Free Energy and Geometry for biphenyl}

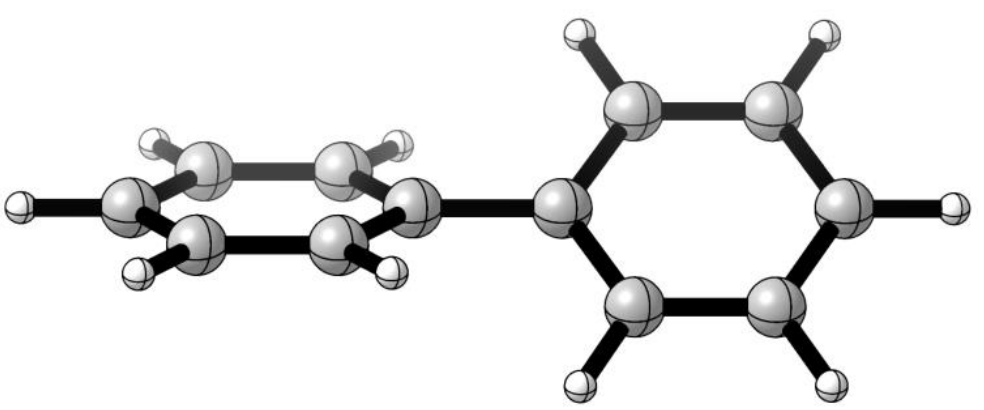

Sum of electronic and thermal free energies: -462.965272 a.u.

$\mathrm{E}\left[\left(\mathrm{SMD}: \mathrm{C}_{2} \mathrm{H}_{4} \mathrm{Cl}_{2}\right) / \mathrm{M} 06-2 \mathrm{X} / 6-311+\mathrm{G}^{* *} / /\left(\mathrm{SMD}: \mathrm{C}_{2} \mathrm{H}_{4} \mathrm{Cl}_{2}\right) / \mathrm{M} 06-2 \mathrm{X} / 6-31 \mathrm{G}^{*}\right]=-463.232569987$ a.u.

Number of imaginary frequencies: 0

\begin{tabular}{|c|c|c|c|c|c|}
\hline \multirow{2}{*}{$\begin{array}{l}\text { Center } \\
\text { Number }\end{array}$} & \multirow{2}{*}{$\begin{array}{l}\text { Atomic } \\
\text { Number }\end{array}$} & \multirow{2}{*}{$\begin{array}{c}\text { Atomic } \\
\text { Type }\end{array}$} & \multicolumn{3}{|c|}{ Coordinates (Ångstroms) } \\
\hline & & & $X$ & $\mathrm{Y}$ & $\mathrm{Z}$ \\
\hline 1 & 6 & 0 & 0.74280 & -0.00000 & 0.00000 \\
\hline 2 & 6 & 0 & -0.74280 & -0.00000 & 0.00000 \\
\hline 3 & 6 & 0 & -1.45970 & -1.14460 & 0.37380 \\
\hline 4 & 6 & 0 & -2.85170 & -1.14490 & 0.37320 \\
\hline 5 & 6 & 0 & -3.55340 & 0.00000 & 0.00000 \\
\hline 6 & 6 & 0 & -2.85170 & 1.14490 & -0.37320 \\
\hline 7 & 6 & 0 & -1.45970 & 1.14460 & -0.37380 \\
\hline 8 & 6 & 0 & 1.45970 & 1.14460 & 0.37380 \\
\hline 9 & 6 & 0 & 2.85170 & 1.14490 & 0.37320 \\
\hline 10 & 6 & 0 & 3.55340 & 0.00000 & 0.00000 \\
\hline 11 & 6 & 0 & 2.85170 & -1.14490 & -0.37320 \\
\hline 12 & 6 & 0 & 1.45970 & -1.14460 & -0.37380 \\
\hline 13 & 1 & 0 & -0.92170 & -2.03480 & 0.68790 \\
\hline 14 & 1 & 0 & -3.38900 & -2.03990 & 0.67280 \\
\hline 15 & 1 & 0 & -4.63920 & 0.00000 & 0.00000 \\
\hline 16 & 1 & 0 & -3.38900 & 2.03990 & -0.67280 \\
\hline 17 & 1 & 0 & -0.92170 & 2.03480 & -0.68790 \\
\hline 18 & 1 & 0 & 0.92170 & 2.03480 & 0.68790 \\
\hline 19 & 1 & 0 & 3.38900 & 2.03990 & 0.67280 \\
\hline 20 & 1 & 0 & 4.63920 & 0.00000 & 0.00000 \\
\hline 21 & 1 & 0 & 3.38900 & -2.03990 & -0.67280 \\
\hline 22 & 1 & 0 & 0.92170 & -2.03480 & -0.68790 \\
\hline
\end{tabular}




\section{Free Energy and Geometry for 9-S}

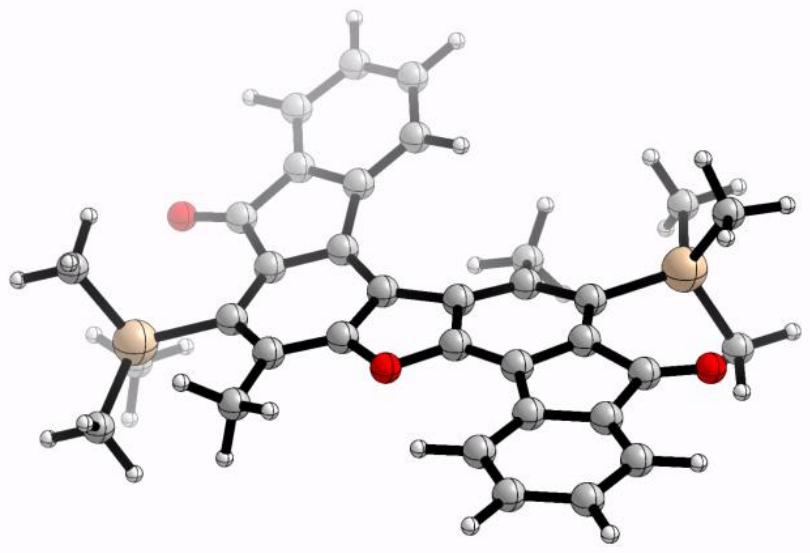

Sum of electronic and thermal free energies: -2118.401347 a.u.

Number of imaginary frequencies: 0

\begin{tabular}{|c|c|c|c|c|c|}
\hline \multirow{2}{*}{$\begin{array}{l}\text { Center } \\
\text { Number }\end{array}$} & \multirow{2}{*}{$\begin{array}{l}\text { Atomic } \\
\text { Number }\end{array}$} & \multirow{2}{*}{$\begin{array}{c}\text { Atomic } \\
\text { Type }\end{array}$} & \multicolumn{3}{|c|}{ Coordinates (Ångstroms) } \\
\hline & & & $X$ & $\mathrm{Y}$ & $\mathrm{Z}$ \\
\hline 1 & 6 & 0 & 0.84930 & 0.07670 & -0.02740 \\
\hline 2 & 6 & 0 & 1.05140 & -1.31830 & -0.09990 \\
\hline 3 & 6 & 0 & 2.26960 & -1.99060 & -0.04190 \\
\hline 4 & 6 & 0 & 3.42790 & -1.19640 & 0.11470 \\
\hline 5 & 6 & 0 & 3.25020 & 0.19710 & 0.01880 \\
\hline 6 & 6 & 0 & 2.00830 & 0.84980 & -0.11920 \\
\hline 7 & 6 & 0 & 2.24500 & 2.27800 & -0.45960 \\
\hline 8 & 6 & 0 & 3.62160 & 2.52920 & -0.36780 \\
\hline 9 & 6 & 0 & 4.31960 & 1.24570 & -0.06450 \\
\hline 10 & 6 & 0 & 4.17270 & 3.75840 & -0.67800 \\
\hline 11 & 6 & 0 & 3.31240 & 4.77140 & -1.11560 \\
\hline 12 & 6 & 0 & 1.95250 & 4.51210 & -1.27590 \\
\hline 13 & 6 & 0 & 1.40500 & 3.26070 & -0.96310 \\
\hline 14 & 8 & 0 & 5.52100 & 1.09130 & 0.02780 \\
\hline 15 & 8 & 0 & -0.14110 & -1.98020 & -0.23180 \\
\hline 16 & 6 & 0 & -2.87370 & 1.11640 & 0.29410 \\
\hline 17 & 6 & 0 & -1.46870 & 1.31620 & 0.38470 \\
\hline 18 & 6 & 0 & -0.60280 & 0.26150 & 0.03340 \\
\hline 19 & 6 & 0 & -1.11860 & -1.03460 & -0.16290 \\
\hline 20 & 6 & 0 & -2.46780 & -1.28740 & -0.19160 \\
\hline 21 & 6 & 0 & -3.31880 & -0.18460 & 0.00100 \\
\hline 22 & 6 & 0 & -4.72630 & -0.73240 & -0.01980 \\
\hline 23 & 6 & 0 & -4.60180 & -2.20090 & -0.27020 \\
\hline
\end{tabular}




\begin{tabular}{|c|c|c|c|c|c|}
\hline 24 & 6 & 0 & -3.24350 & -2.53150 & -0.36230 \\
\hline 25 & 6 & 0 & -2.85290 & -3.84370 & -0.58130 \\
\hline 26 & 6 & 0 & -3.85690 & -4.81310 & -0.70670 \\
\hline 27 & 6 & 0 & -5.20820 & -4.47980 & -0.61380 \\
\hline 28 & 6 & 0 & -5.59660 & -3.15420 & -0.38980 \\
\hline 29 & 8 & 0 & -5.76310 & -0.12990 & 0.16790 \\
\hline 30 & 1 & 0 & 5.24470 & 3.91740 & -0.60280 \\
\hline 31 & 1 & 0 & 3.70820 & 5.75090 & -1.36420 \\
\hline 32 & 1 & 0 & 1.30240 & 5.29030 & -1.66420 \\
\hline 33 & 1 & 0 & 0.35530 & 3.06380 & -1.14660 \\
\hline 34 & 1 & 0 & -1.80560 & -4.11870 & -0.65370 \\
\hline 35 & 1 & 0 & -3.57480 & -5.84740 & -0.87940 \\
\hline 36 & 1 & 0 & -5.96110 & -5.25480 & -0.71510 \\
\hline 37 & 1 & 0 & -6.64360 & -2.87570 & -0.31130 \\
\hline 38 & 14 & 0 & 5.18150 & -1.90640 & 0.46410 \\
\hline 39 & 14 & 0 & -4.17320 & 2.51960 & 0.50370 \\
\hline 40 & 6 & 0 & 5.17710 & -3.73360 & 0.93770 \\
\hline 41 & 1 & 0 & 4.94970 & -4.41840 & 0.11660 \\
\hline 42 & 1 & 0 & 6.19660 & -3.95950 & 1.27830 \\
\hline 43 & 1 & 0 & 4.50490 & -3.95440 & 1.77350 \\
\hline 44 & 6 & 0 & 6.24020 & -1.76840 & -1.08450 \\
\hline 45 & 1 & 0 & 6.31480 & -0.74260 & -1.45250 \\
\hline 46 & 1 & 0 & 7.25350 & -2.13090 & -0.87290 \\
\hline 47 & 1 & 0 & 5.82580 & -2.39600 & -1.88230 \\
\hline 48 & 6 & 0 & 5.89340 & -1.03720 & 1.98400 \\
\hline 49 & 1 & 0 & 6.92590 & -0.72220 & 1.79790 \\
\hline 50 & 1 & 0 & 5.32800 & -0.14700 & 2.26980 \\
\hline 51 & 1 & 0 & 5.89940 & -1.72620 & 2.83630 \\
\hline 52 & 1 & 0 & -3.44920 & 4.26090 & 0.60530 \\
\hline 53 & 1 & 0 & -4.30850 & 4.94440 & 0.57250 \\
\hline 54 & 1 & 0 & -2.89830 & 4.47400 & 1.52520 \\
\hline 55 & 1 & 0 & -2.81250 & 4.50940 & -0.25040 \\
\hline 56 & 6 & 0 & -5.13980 & 2.27140 & 2.09790 \\
\hline 57 & 1 & 0 & -4.47850 & 2.42000 & 2.96000 \\
\hline 58 & 1 & 0 & -5.94180 & 3.01650 & 2.16640 \\
\hline 59 & 1 & 0 & -5.58940 & 1.27910 & 2.17190 \\
\hline 60 & 6 & 0 & -5.21660 & 2.59850 & -1.06430 \\
\hline 61 & 1 & 0 & -4.63060 & 3.06660 & -1.86430 \\
\hline 62 & 1 & 0 & -5.57490 & 1.63050 & -1.41630 \\
\hline 63 & 1 & 0 & -6.09110 & 3.23670 & -0.88600 \\
\hline 64 & 6 & 0 & 2.26320 & -3.49310 & -0.16380 \\
\hline 65 & 1 & 0 & 2.42110 & -3.97990 & 0.80330 \\
\hline 66 & 1 & 0 & 1.30580 & -3.83950 & -0.55830 \\
\hline 67 & 1 & 0 & 3.04820 & -3.83190 & -0.84350 \\
\hline 68 & 6 & 0 & -0.89620 & 2.54920 & 1.04050 \\
\hline 69 & 1 & 0 & 0.15740 & 2.40230 & 1.28610 \\
\hline 70 & 1 & 0 & -0.98090 & 3.45510 & 0.43790 \\
\hline 71 & 1 & 0 & -1.42860 & 2.73300 & 1.97920 \\
\hline
\end{tabular}


Free Energy and Geometry for 9-U (closed)

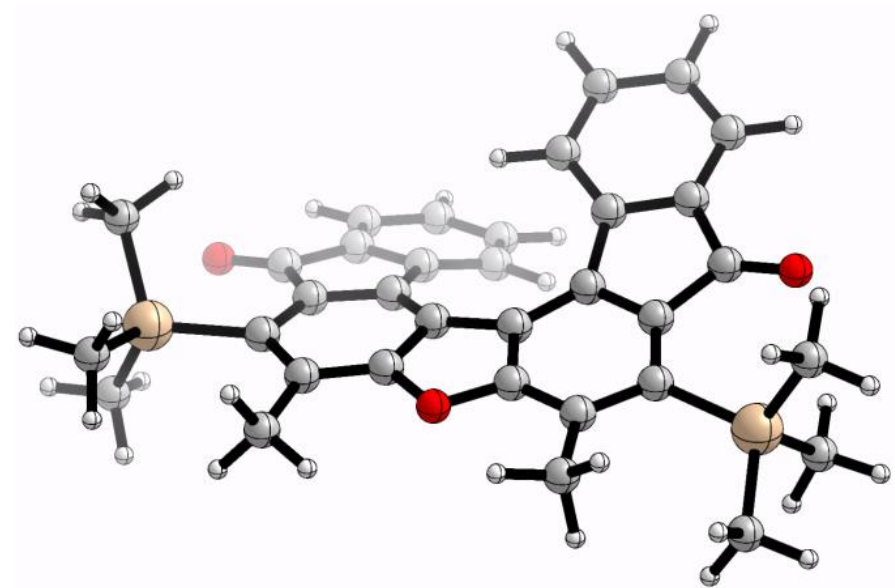

Sum of electronic and thermal free energies: -2118.403847 a.u.

Number of imaginary frequencies: 0

\begin{tabular}{|c|c|c|c|c|c|}
\hline \multirow{2}{*}{$\begin{array}{l}\text { Center } \\
\text { Number }\end{array}$} & \multirow{2}{*}{$\begin{array}{l}\text { Atomic } \\
\text { Number }\end{array}$} & \multirow{2}{*}{$\begin{array}{c}\text { Atomic } \\
\text { Type }\end{array}$} & \multicolumn{3}{|c|}{ Coordinates (Ångstroms) } \\
\hline & & & $\mathrm{X}$ & Y & $\mathrm{Z}$ \\
\hline 1 & 6 & 0 & -0.73260 & 0.33600 & 0.04100 \\
\hline 2 & 6 & 0 & -1.10740 & 1.69400 & -0.01830 \\
\hline 3 & 6 & 0 & -2.40500 & 2.19460 & -0.09920 \\
\hline 4 & 6 & 0 & -3.45540 & 1.24830 & -0.11290 \\
\hline 5 & 6 & 0 & -3.09650 & -0.09240 & 0.13430 \\
\hline 6 & 6 & 0 & -1.77460 & -0.56230 & 0.26980 \\
\hline 7 & 6 & 0 & -1.79560 & -1.95520 & 0.78350 \\
\hline 8 & 6 & 0 & -3.13000 & -2.37990 & 0.84240 \\
\hline 9 & 6 & 0 & -4.01030 & -1.24260 & 0.44180 \\
\hline 10 & 6 & 0 & -3.49000 & -3.62180 & 1.33080 \\
\hline 11 & 6 & 0 & -2.47180 & -4.46560 & 1.78930 \\
\hline 12 & 6 & 0 & -1.14720 & -4.03240 & 1.78340 \\
\hline 13 & 6 & 0 & -0.79340 & -2.76870 & 1.29150 \\
\hline 14 & 6 & 0 & -2.58650 & 3.69120 & -0.12900 \\
\hline 15 & 8 & 0 & -5.22510 & -1.25260 & 0.44100 \\
\hline 16 & 8 & 0 & -0.00950 & 2.50680 & 0.02700 \\
\hline 17 & 6 & 0 & 1.76940 & -0.55250 & -0.25890 \\
\hline 18 & 6 & 0 & 0.72390 & 0.33940 & -0.02030 \\
\hline 19 & 6 & 0 & 1.09270 & 1.69880 & 0.05890 \\
\hline 20 & 6 & 0 & 2.38800 & 2.20440 & 0.14590 \\
\hline 21 & 6 & 0 & 3.44190 & 1.26250 & 0.13900 \\
\hline 22 & 6 & 0 & 3.08800 & -0.07550 & -0.12170 \\
\hline 23 & 6 & 0 & 4.01100 & -1.21630 & -0.43300 \\
\hline 24 & 6 & 0 & 3.13920 & -2.35780 & -0.84110 \\
\hline 25 & 6 & 0 & 1.80130 & -1.94240 & -0.78110 \\
\hline
\end{tabular}




\begin{tabular}{|c|c|c|c|c|c|}
\hline 26 & 6 & 0 & 3.50770 & -3.59500 & -1.33490 \\
\hline 27 & 6 & 0 & 2.49570 & -4.44360 & -1.79810 \\
\hline 28 & 6 & 0 & 1.16810 & -4.01970 & -1.79100 \\
\hline 29 & 6 & 0 & 0.80530 & -2.76080 & -1.29330 \\
\hline 30 & 8 & 0 & 5.22570 & -1.21320 & -0.42650 \\
\hline 31 & 6 & 0 & 2.56800 & 3.69990 & 0.20900 \\
\hline 32 & 1 & 0 & -4.53430 & -3.91810 & 1.37090 \\
\hline 33 & 1 & 0 & -2.71550 & -5.45000 & 2.17600 \\
\hline 34 & 1 & 0 & -0.37050 & -4.68180 & 2.17590 \\
\hline 35 & 1 & 0 & 0.23900 & -2.43920 & 1.32550 \\
\hline 36 & 1 & 0 & -3.41210 & 3.99770 & 0.51680 \\
\hline 37 & 1 & 0 & -1.68090 & 4.18820 & 0.22520 \\
\hline 38 & 1 & 0 & -2.79260 & 4.05750 & -1.13920 \\
\hline 39 & 1 & 0 & 4.55390 & -3.88430 & -1.37520 \\
\hline 40 & 1 & 0 & 2.74630 & -5.42460 & -2.18910 \\
\hline 41 & 1 & 0 & 0.39610 & -4.67270 & -2.18680 \\
\hline 42 & 1 & 0 & -0.22940 & -2.43850 & -1.32580 \\
\hline 43 & 1 & 0 & 2.83130 & 4.03490 & 1.21670 \\
\hline 44 & 1 & 0 & 3.35730 & 4.02740 & -0.47180 \\
\hline 45 & 1 & 0 & 1.64470 & 4.20630 & -0.07930 \\
\hline 46 & 14 & 0 & -5.28520 & 1.70020 & -0.50070 \\
\hline 47 & 14 & 0 & 5.28240 & 1.70600 & 0.47870 \\
\hline 48 & 6 & 0 & -5.49260 & 3.43370 & -1.22060 \\
\hline 49 & 1 & 0 & -5.36110 & 4.24580 & -0.50090 \\
\hline 50 & 1 & 0 & -4.83780 & 3.61850 & -2.07850 \\
\hline 51 & 1 & 0 & -6.52600 & 3.48860 & -1.58850 \\
\hline 52 & 6 & 0 & -6.32830 & 1.64320 & 1.06200 \\
\hline 53 & 1 & 0 & -7.37460 & 1.86220 & 0.81630 \\
\hline 54 & 1 & 0 & -6.28880 & 0.67140 & 1.55830 \\
\hline 55 & 1 & 0 & -5.98840 & 2.41040 & 1.76770 \\
\hline 56 & 6 & 0 & -5.88610 & 0.59420 & -1.90240 \\
\hline 57 & 1 & 0 & -6.95820 & 0.76600 & -2.06010 \\
\hline 58 & 1 & 0 & -5.37330 & 0.87330 & -2.83080 \\
\hline 59 & 1 & 0 & -5.73810 & -0.47200 & -1.72860 \\
\hline 60 & 6 & 0 & 5.95820 & 0.52440 & 1.79090 \\
\hline 61 & 1 & 0 & 6.91230 & 0.09410 & 1.46880 \\
\hline 62 & 1 & 0 & 6.13110 & 1.06870 & 2.72640 \\
\hline 63 & 1 & 0 & 5.28110 & -0.30700 & 2.00260 \\
\hline 64 & 6 & 0 & 5.51020 & 3.41920 & 1.23760 \\
\hline 65 & 1 & 0 & 5.32360 & 4.25130 & 0.55420 \\
\hline 66 & 1 & 0 & 4.90550 & 3.56470 & 2.13920 \\
\hline 67 & 1 & 0 & 6.56290 & 3.47820 & 1.54530 \\
\hline 68 & 6 & 0 & 6.24420 & 1.70350 & -1.13740 \\
\hline 69 & 1 & 0 & 5.86940 & 2.49000 & -1.80300 \\
\hline 70 & 1 & 0 & 7.30230 & 1.91460 & -0.94000 \\
\hline 71 & 1 & 0 & 6.17890 & 0.74610 & -1.65940 \\
\hline
\end{tabular}


Free Energy and Geometry for 9-U (open)

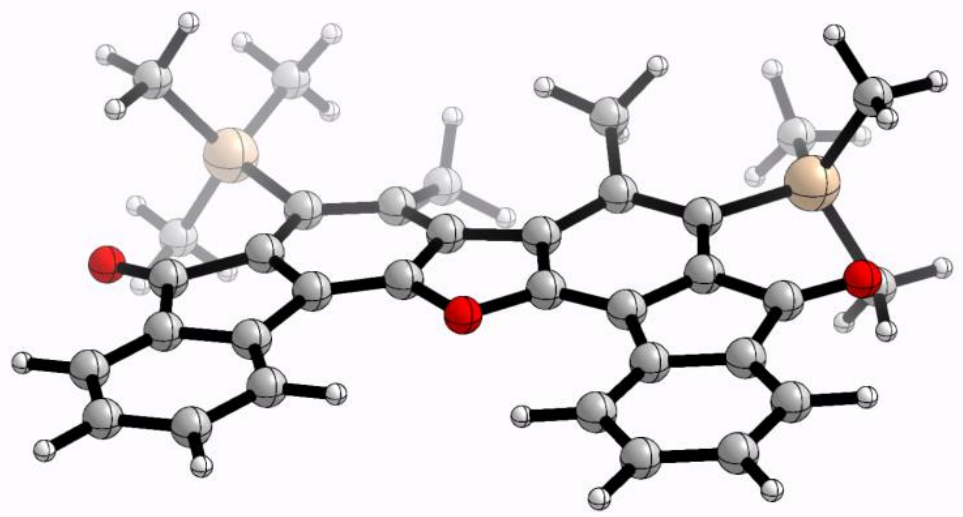

Sum of electronic and thermal free energies: -2118.401573 a.u.

Number of imaginary frequencies: 0

\begin{tabular}{|c|c|c|c|c|c|}
\hline \multirow{2}{*}{$\begin{array}{l}\text { Center } \\
\text { Number }\end{array}$} & \multirow{2}{*}{$\begin{array}{l}\text { Atomic } \\
\text { Number }\end{array}$} & \multirow{2}{*}{$\begin{array}{c}\text { Atomic } \\
\text { Type }\end{array}$} & \multicolumn{3}{|c|}{ Coordinates (Ångstroms) } \\
\hline & & & $X$ & Y & $\mathrm{Z}$ \\
\hline 1 & 6 & 0 & 0.73580 & -0.70880 & -0.01550 \\
\hline 2 & 6 & 0 & 1.08820 & 0.65540 & 0.03180 \\
\hline 3 & 8 & 0 & 0.00000 & 1.47820 & 0.00000 \\
\hline 4 & 6 & 0 & -1.08820 & 0.65540 & -0.03170 \\
\hline 5 & 6 & 0 & -0.73580 & -0.70880 & 0.01550 \\
\hline 6 & 6 & 0 & -2.39390 & 1.08050 & -0.03550 \\
\hline 7 & 6 & 0 & -3.37940 & 0.07970 & -0.00990 \\
\hline 8 & 6 & 0 & -3.10640 & -1.29450 & 0.09090 \\
\hline 9 & 6 & 0 & -1.74250 & -1.68050 & 0.19840 \\
\hline 10 & 6 & 0 & 1.74250 & -1.68050 & -0.19840 \\
\hline 11 & 6 & 0 & 3.10640 & -1.29450 & -0.09080 \\
\hline 12 & 6 & 0 & 3.37940 & 0.07970 & 0.00990 \\
\hline 13 & 6 & 0 & 2.39390 & 1.08050 & 0.03550 \\
\hline 14 & 6 & 0 & -4.70690 & 0.79540 & 0.05300 \\
\hline 15 & 6 & 0 & -4.39690 & 2.25740 & 0.00570 \\
\hline 16 & 6 & 0 & -3.00630 & 2.42410 & -0.03990 \\
\hline 17 & 6 & 0 & 3.00630 & 2.42410 & 0.03990 \\
\hline 18 & 6 & 0 & 4.39690 & 2.25740 & -0.00570 \\
\hline 19 & 6 & 0 & 4.70690 & 0.79540 & -0.05300 \\
\hline 20 & 6 & 0 & -2.45240 & 3.69430 & -0.07940 \\
\hline 21 & 6 & 0 & -3.32540 & 4.79040 & -0.07200 \\
\hline 22 & 6 & 0 & -4.70880 & 4.62000 & -0.02400 \\
\hline 23 & 6 & 0 & -5.26290 & 3.33560 & 0.01790 \\
\hline 24 & 6 & 0 & 5.26290 & 3.33560 & -0.01790 \\
\hline 25 & 6 & 0 & 4.70880 & 4.62000 & 0.02400 \\
\hline 26 & 6 & 0 & 3.32540 & 4.79040 & 0.07210 \\
\hline
\end{tabular}




\begin{tabular}{|c|c|c|c|c|c|}
\hline 27 & 6 & 0 & 2.45240 & 3.69430 & 0.07950 \\
\hline 28 & 8 & 0 & -5.81070 & 0.30520 & 0.17290 \\
\hline 29 & 8 & 0 & 5.81070 & 0.30520 & -0.17300 \\
\hline 30 & 14 & 0 & 4.55480 & -2.55400 & 0.03650 \\
\hline 31 & 14 & 0 & -4.55480 & -2.55400 & -0.03650 \\
\hline 32 & 6 & 0 & -3.99000 & -4.33140 & -0.33830 \\
\hline 33 & 6 & 0 & -5.57870 & -2.56520 & 1.53980 \\
\hline 34 & 6 & 0 & -5.52560 & -2.16780 & -1.60530 \\
\hline 35 & 6 & 0 & 5.52570 & -2.16770 & 1.60530 \\
\hline 36 & 6 & 0 & 3.99010 & -4.33140 & 0.33850 \\
\hline 37 & 6 & 0 & 5.57860 & -2.56530 & -1.53990 \\
\hline 38 & 1 & 0 & -1.37790 & 3.84250 & -0.11620 \\
\hline 39 & 1 & 0 & -2.91390 & 5.79470 & -0.10350 \\
\hline 40 & 1 & 0 & -5.35770 & 5.48990 & -0.01870 \\
\hline 41 & 1 & 0 & -6.33760 & 3.18300 & 0.05800 \\
\hline 42 & 1 & 0 & 6.33760 & 3.18300 & -0.05800 \\
\hline 43 & 1 & 0 & 5.35770 & 5.48990 & 0.01870 \\
\hline 44 & 1 & 0 & 2.91390 & 5.79470 & 0.10360 \\
\hline 45 & 1 & 0 & 1.37790 & 3.84250 & 0.11630 \\
\hline 46 & 1 & 0 & -4.88480 & -4.88960 & -0.64430 \\
\hline 47 & 1 & 0 & -3.26860 & -4.40960 & -1.15870 \\
\hline 48 & 1 & 0 & -3.57530 & -4.83590 & 0.53820 \\
\hline 49 & 1 & 0 & -4.97460 & -2.92680 & 2.38030 \\
\hline 50 & 1 & 0 & -5.96590 & -1.57520 & 1.79060 \\
\hline 51 & 1 & 0 & -6.42900 & -3.24850 & 1.42660 \\
\hline 52 & 1 & 0 & -4.92200 & -2.44030 & -2.47950 \\
\hline 53 & 1 & 0 & -6.42970 & -2.78900 & -1.62930 \\
\hline 54 & 1 & 0 & -5.83200 & -1.12610 & -1.70520 \\
\hline 55 & 1 & 0 & 6.42990 & -2.78880 & 1.62910 \\
\hline 56 & 1 & 0 & 5.83200 & -1.12610 & 1.70520 \\
\hline 57 & 1 & 0 & 4.92220 & -2.44040 & 2.47950 \\
\hline 58 & 1 & 0 & 4.88490 & -4.88960 & 0.64450 \\
\hline 59 & 1 & 0 & 3.26870 & -4.40950 & 1.15910 \\
\hline 60 & 1 & 0 & 3.57520 & -4.83600 & -0.53790 \\
\hline 61 & 1 & 0 & 6.42890 & -3.24860 & -1.42670 \\
\hline 62 & 1 & 0 & 4.97440 & -2.92690 & -2.38030 \\
\hline 63 & 1 & 0 & 5.96570 & -1.57520 & -1.79080 \\
\hline 64 & 6 & 0 & 1.37050 & -3.05770 & -0.69380 \\
\hline 65 & 1 & 0 & 2.11090 & -3.39540 & -1.42300 \\
\hline 66 & 1 & 0 & 1.30760 & -3.81510 & 0.09210 \\
\hline 67 & 1 & 0 & 0.40730 & -3.01820 & -1.20650 \\
\hline 68 & 6 & 0 & -1.37050 & -3.05770 & 0.69380 \\
\hline 69 & 1 & 0 & -1.30770 & -3.81500 & -0.09220 \\
\hline 70 & 1 & 0 & -0.40720 & -3.01830 & 1.20640 \\
\hline 71 & 1 & 0 & -2.11090 & -3.39540 & 1.42290 \\
\hline
\end{tabular}




\section{Free Energy and Geometry for 11-S}

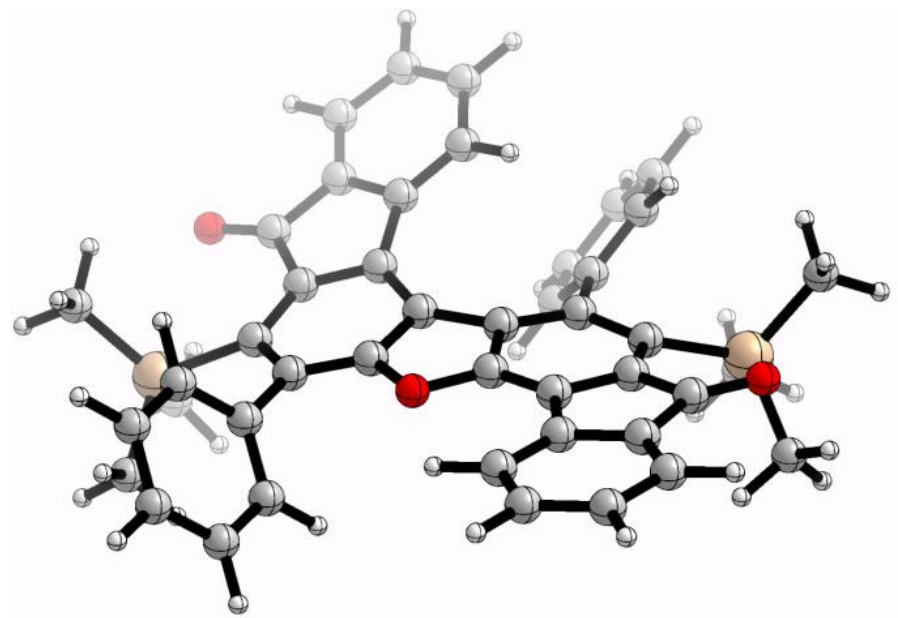

Sum of electronic and thermal free energies: -2501.635647 a.u.

Number of imaginary frequencies: 0

\begin{tabular}{|c|c|c|c|c|c|}
\hline \multirow{2}{*}{$\begin{array}{l}\text { Center } \\
\text { Number }\end{array}$} & \multirow{2}{*}{$\begin{array}{l}\text { Atomic } \\
\text { Number }\end{array}$} & \multirow{2}{*}{$\begin{array}{c}\text { Atomic } \\
\text { Type }\end{array}$} & \multicolumn{3}{|c|}{ Coordinates (Ångstroms) } \\
\hline & & & $X$ & $\mathrm{Y}$ & $\mathrm{Z}$ \\
\hline 1 & 6 & 0 & -0.59340 & -0.40230 & -0.23580 \\
\hline 2 & 6 & 0 & -1.18830 & 0.87560 & -0.13260 \\
\hline 3 & 6 & 0 & -2.54350 & 1.15400 & 0.03730 \\
\hline 4 & 6 & 0 & -3.42000 & 0.05390 & 0.15670 \\
\hline 5 & 6 & 0 & -2.86450 & -1.20480 & -0.13660 \\
\hline 6 & 6 & 0 & -1.50260 & -1.45540 & -0.40630 \\
\hline 7 & 6 & 0 & -1.36890 & -2.84050 & -0.93510 \\
\hline 8 & 6 & 0 & -2.61400 & -3.47770 & -0.83080 \\
\hline 9 & 6 & 0 & -3.61470 & -2.48540 & -0.34890 \\
\hline 10 & 6 & 0 & -2.82990 & -4.76580 & -1.28430 \\
\hline 11 & 6 & 0 & -1.75870 & -5.43860 & -1.88160 \\
\hline 12 & 6 & 0 & -0.53930 & -4.78720 & -2.05880 \\
\hline 13 & 6 & 0 & -0.33690 & -3.47710 & -1.60610 \\
\hline 14 & 8 & 0 & -4.81110 & -2.66860 & -0.24440 \\
\hline 15 & 8 & 0 & -0.25340 & 1.86750 & -0.21180 \\
\hline 16 & 6 & 0 & 3.29340 & -0.26450 & 0.09810 \\
\hline 17 & 6 & 0 & 2.03110 & -0.91290 & 0.03450 \\
\hline 18 & 6 & 0 & 0.85650 & -0.15320 & -0.18780 \\
\hline 19 & 6 & 0 & 0.95720 & 1.25090 & -0.23870 \\
\hline 20 & 6 & 0 & 2.16580 & 1.90370 & -0.31260 \\
\hline 21 & 6 & 0 & 3.31220 & 1.11030 & -0.18590 \\
\hline 22 & 6 & 0 & 4.49020 & 2.01570 & -0.43810 \\
\hline 23 & 6 & 0 & 3.92890 & 3.39550 & -0.58220 \\
\hline 24 & 6 & 0 & 2.53020 & 3.32250 & -0.50600 \\
\hline
\end{tabular}




\begin{tabular}{|c|c|c|c|c|c|}
\hline 25 & 6 & 0 & 1.75690 & 4.46680 & -0.62340 \\
\hline 26 & 6 & 0 & 2.42010 & 5.68620 & -0.81750 \\
\hline 27 & 6 & 0 & 3.81060 & 5.75480 & -0.89840 \\
\hline 28 & 6 & 0 & 4.58610 & 4.59510 & -0.78460 \\
\hline 29 & 8 & 0 & 5.64690 & 1.68540 & -0.59230 \\
\hline 30 & 1 & 0 & -3.81010 & -5.22500 & -1.19400 \\
\hline 31 & 1 & 0 & -1.88640 & -6.45480 & -2.24080 \\
\hline 32 & 1 & 0 & 0.27220 & -5.29800 & -2.56920 \\
\hline 33 & 1 & 0 & 0.60280 & -2.97610 & -1.79520 \\
\hline 34 & 1 & 0 & 0.67350 & 4.42750 & -0.56780 \\
\hline 35 & 1 & 0 & 1.83610 & 6.59690 & -0.90990 \\
\hline 36 & 1 & 0 & 4.29320 & 6.71480 & -1.05110 \\
\hline 37 & 1 & 0 & 5.66980 & 4.63010 & -0.84870 \\
\hline 38 & 6 & 0 & -2.99660 & 2.56990 & 0.00070 \\
\hline 39 & 6 & 0 & -2.50900 & 3.52480 & 0.89930 \\
\hline 40 & 6 & 0 & -3.92440 & 2.95830 & -0.97170 \\
\hline 41 & 6 & 0 & -2.96600 & 4.83850 & 0.84320 \\
\hline 42 & 1 & 0 & -1.78640 & 3.23020 & 1.65540 \\
\hline 43 & 6 & 0 & -4.37640 & 4.27440 & -1.03160 \\
\hline 44 & 1 & 0 & -4.28820 & 2.22150 & -1.68400 \\
\hline 45 & 6 & 0 & -3.90230 & 5.21550 & -0.11970 \\
\hline 46 & 1 & 0 & -2.59300 & 5.56910 & 1.55480 \\
\hline 47 & 1 & 0 & -5.09700 & 4.56390 & -1.79050 \\
\hline 48 & 1 & 0 & -4.25640 & 6.24110 & -0.16160 \\
\hline 49 & 6 & 0 & 1.95750 & -2.37990 & 0.24760 \\
\hline 50 & 6 & 0 & 2.74440 & -3.23380 & -0.53520 \\
\hline 51 & 6 & 0 & 1.13730 & -2.92600 & 1.23900 \\
\hline 52 & 6 & 0 & 2.71460 & -4.60990 & -0.32920 \\
\hline 53 & 1 & 0 & 3.36560 & -2.81110 & -1.32140 \\
\hline 54 & 6 & 0 & 1.11810 & -4.30170 & 1.45530 \\
\hline 55 & 1 & 0 & 0.52860 & -2.26820 & 1.85450 \\
\hline 56 & 6 & 0 & 1.90460 & -5.14590 & 0.67260 \\
\hline 57 & 1 & 0 & 3.32370 & -5.26280 & -0.94750 \\
\hline 58 & 1 & 0 & 0.48660 & -4.71550 & 2.23580 \\
\hline 59 & 1 & 0 & 1.88320 & -6.21860 & 0.83980 \\
\hline 60 & 14 & 0 & -5.19570 & 0.22090 & 0.88720 \\
\hline 61 & 14 & 0 & 4.86160 & -1.04660 & 0.91170 \\
\hline 62 & 6 & 0 & -5.42990 & 1.86560 & 1.78350 \\
\hline 63 & 1 & 0 & -5.55960 & 2.72970 & 1.12730 \\
\hline 64 & 1 & 0 & -6.33850 & 1.76770 & 2.39240 \\
\hline 65 & 1 & 0 & -4.60190 & 2.07710 & 2.46920 \\
\hline 66 & 6 & 0 & -6.52330 & 0.06610 & -0.43220 \\
\hline 67 & 1 & 0 & -7.51320 & 0.06490 & 0.03980 \\
\hline 68 & 1 & 0 & -6.48640 & 0.91820 & -1.12040 \\
\hline 69 & 1 & 0 & -6.41920 & -0.85560 & -1.00960 \\
\hline 70 & 6 & 0 & -5.35740 & -1.03370 & 2.28450 \\
\hline 71 & 1 & 0 & -5.24540 & -2.07260 & 1.97360 \\
\hline 72 & 1 & 0 & -4.61310 & -0.81780 & 3.06060 \\
\hline 73 & 1 & 0 & -6.34660 & -0.92150 & 2.74590 \\
\hline 74 & 6 & 0 & 6.07620 & -1.73300 & -0.34720 \\
\hline 75 & 1 & 0 & 7.01150 & -2.00210 & 0.15850 \\
\hline 76 & 1 & 0 & 5.69410 & -2.63180 & -0.84200 \\
\hline
\end{tabular}




$\begin{array}{llllrr}77 & 1 & 0 & 6.31010 & -0.98540 & -1.11130 \\ 78 & 6 & 0 & 4.39810 & -2.37980 & 2.16620 \\ 79 & 1 & 0 & 4.05740 & -3.32560 & 1.73970 \\ 80 & 1 & 0 & 5.29880 & -2.58390 & 2.75930 \\ 81 & 1 & 0 & 3.62970 & -2.01910 & 2.86020 \\ 82 & 6 & 0 & 5.69160 & 0.27320 & 1.98460 \\ 83 & 1 & 0 & 6.48790 & 0.80600 & 1.46150 \\ 84 & 1 & 0 & 4.97340 & 1.01670 & 2.34990 \\ 85 & 1 & 0 & 6.12810 & -0.21580 & 2.86330 \\ -\end{array}$




\section{Free Energy and Geometry for 11-U}

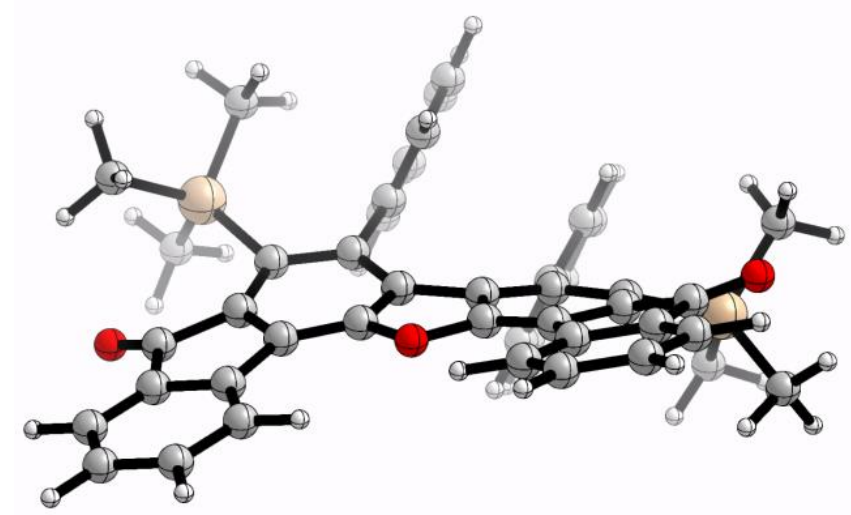

Sum of electronic and thermal free energies: -2501.631661 a.u.

Number of imaginary frequencies: 0

\begin{tabular}{|c|c|c|c|c|c|}
\hline \multirow{2}{*}{$\begin{array}{l}\text { Center } \\
\text { Number }\end{array}$} & \multirow{2}{*}{$\begin{array}{l}\text { Atomic } \\
\text { Number }\end{array}$} & \multirow{2}{*}{$\begin{array}{c}\text { Atomic } \\
\text { Type }\end{array}$} & \multicolumn{3}{|c|}{ Coordinates (Ångstroms) } \\
\hline & & & $\mathrm{X}$ & $\mathrm{Y}$ & $\mathrm{Z}$ \\
\hline 1 & 6 & 0 & 0.73660 & 0.08680 & 0.00990 \\
\hline 2 & 6 & 0 & 1.08180 & 1.44880 & -0.09230 \\
\hline 3 & 8 & 0 & 0.00010 & 2.27290 & -0.00010 \\
\hline 4 & 6 & 0 & -1.08170 & 1.44890 & 0.09220 \\
\hline 5 & 6 & 0 & -0.73650 & 0.08690 & -0.01000 \\
\hline 6 & 6 & 0 & -2.37660 & 1.86470 & 0.30240 \\
\hline 7 & 6 & 0 & -3.36260 & 0.87150 & 0.26010 \\
\hline 8 & 6 & 0 & -3.12460 & -0.46190 & -0.11730 \\
\hline 9 & 6 & 0 & -1.76650 & -0.86280 & -0.21690 \\
\hline 10 & 6 & 0 & 1.76650 & -0.86290 & 0.21680 \\
\hline 11 & 6 & 0 & 3.12460 & -0.46210 & 0.11730 \\
\hline 12 & 6 & 0 & 3.36270 & 0.87120 & -0.26010 \\
\hline 13 & 6 & 0 & 2.37680 & 1.86450 & -0.30250 \\
\hline 14 & 6 & 0 & -4.64270 & 1.52180 & 0.71810 \\
\hline 15 & 6 & 0 & -4.33860 & 2.97990 & 0.86420 \\
\hline 16 & 6 & 0 & -2.97270 & 3.18020 & 0.61730 \\
\hline 17 & 6 & 0 & 2.97290 & 3.18000 & -0.61740 \\
\hline 18 & 6 & 0 & 4.33890 & 2.97950 & -0.86410 \\
\hline 19 & 6 & 0 & 4.64290 & 1.52140 & -0.71790 \\
\hline 20 & 6 & 0 & -2.41910 & 4.44700 & 0.71290 \\
\hline 21 & 6 & 0 & -3.26780 & 5.50870 & 1.05480 \\
\hline 22 & 6 & 0 & -4.62490 & 5.30530 & 1.30180 \\
\hline 23 & 6 & 0 & -5.17710 & 4.02210 & 1.21390 \\
\hline 24 & 6 & 0 & 5.17750 & 4.02170 & -1.21380 \\
\hline 25 & 6 & 0 & 4.62540 & 5.30500 & -1.30170 \\
\hline 26 & 6 & 0 & 3.26830 & 5.50840 & -1.05490 \\
\hline
\end{tabular}




\begin{tabular}{|c|c|c|c|c|c|}
\hline 27 & 6 & 0 & 2.41950 & 4.44680 & -0.71310 \\
\hline 28 & 8 & 0 & -5.67750 & 0.96670 & 1.02050 \\
\hline 29 & 8 & 0 & 5.67780 & 0.96630 & -1.02000 \\
\hline 30 & 14 & 0 & 4.62340 & -1.49150 & 0.77170 \\
\hline 31 & 6 & 0 & 1.44300 & -2.24140 & 0.67740 \\
\hline 32 & 14 & 0 & -4.62350 & -1.49120 & -0.77160 \\
\hline 33 & 6 & 0 & -4.14990 & -2.61620 & -2.20980 \\
\hline 34 & 6 & 0 & -5.42450 & -2.49650 & 0.59890 \\
\hline 35 & 6 & 0 & -5.87570 & -0.31640 & -1.56970 \\
\hline 36 & 6 & 0 & 5.87530 & -0.31670 & 1.57030 \\
\hline 37 & 6 & 0 & 4.14980 & -2.61690 & 2.20940 \\
\hline 38 & 6 & 0 & 5.42460 & -2.49640 & -0.59910 \\
\hline 39 & 6 & 0 & 1.83460 & -3.36150 & -0.06190 \\
\hline 40 & 6 & 0 & 1.64750 & -4.64310 & 0.45060 \\
\hline 41 & 6 & 0 & 1.07930 & -4.81600 & 1.71270 \\
\hline 42 & 6 & 0 & 0.66820 & -3.70390 & 2.44590 \\
\hline 43 & 6 & 0 & 0.83800 & -2.42350 & 1.92570 \\
\hline 44 & 6 & 0 & -1.83500 & -3.36140 & 0.06190 \\
\hline 45 & 6 & 0 & -1.64810 & -4.64300 & -0.45070 \\
\hline 46 & 6 & 0 & -1.07990 & -4.81600 & -1.71280 \\
\hline 47 & 6 & 0 & -0.66850 & -3.70400 & -2.44590 \\
\hline 48 & 6 & 0 & -0.83810 & -2.42350 & -1.92570 \\
\hline 49 & 6 & 0 & -1.44320 & -2.24140 & -0.67740 \\
\hline 50 & 1 & 0 & -1.36280 & 4.61890 & 0.53290 \\
\hline 51 & 1 & 0 & -2.85690 & 6.51070 & 1.13230 \\
\hline 52 & 1 & 0 & -5.25510 & 6.14840 & 1.56620 \\
\hline 53 & 1 & 0 & -6.23060 & 3.84460 & 1.41040 \\
\hline 54 & 1 & 0 & 6.23100 & 3.84420 & -1.41000 \\
\hline 55 & 1 & 0 & 5.25570 & 6.14800 & -1.56610 \\
\hline 56 & 1 & 0 & 2.85750 & 6.51050 & -1.13260 \\
\hline 57 & 1 & 0 & 1.36310 & 4.61870 & -0.53330 \\
\hline 58 & 1 & 0 & -5.09050 & -2.98990 & -2.63510 \\
\hline 59 & 1 & 0 & -3.63960 & -2.05370 & -3.00020 \\
\hline 60 & 1 & 0 & -3.53430 & -3.47900 & -1.94910 \\
\hline 61 & 1 & 0 & -4.76210 & -3.28910 & 0.96240 \\
\hline 62 & 1 & 0 & -5.69670 & -1.85610 & 1.44370 \\
\hline 63 & 1 & 0 & -6.34000 & -2.96990 & 0.22420 \\
\hline 64 & 1 & 0 & -6.31200 & -0.81670 & -2.44210 \\
\hline 65 & 1 & 0 & -6.68720 & -0.03780 & -0.89500 \\
\hline 66 & 1 & 0 & -5.40620 & 0.60770 & -1.92700 \\
\hline 67 & 1 & 0 & 6.31110 & -0.81700 & 2.44300 \\
\hline 68 & 1 & 0 & 6.68730 & -0.03850 & 0.89590 \\
\hline 69 & 1 & 0 & 5.40580 & 0.60750 & 1.92710 \\
\hline 70 & 1 & 0 & 5.09030 & -2.99080 & 2.63470 \\
\hline 71 & 1 & 0 & 3.63940 & -2.05470 & 3.00000 \\
\hline 72 & 1 & 0 & 3.53430 & -3.47970 & 1.94850 \\
\hline 73 & 1 & 0 & 6.33990 & -2.97020 & -0.22440 \\
\hline 74 & 1 & 0 & 4.76210 & -3.28860 & -0.96320 \\
\hline 75 & 1 & 0 & 5.69720 & -1.85550 & -1.44350 \\
\hline 76 & 1 & 0 & 2.28620 & -3.22250 & -1.04110 \\
\hline 77 & 1 & 0 & 1.95010 & -5.50710 & -0.13430 \\
\hline 78 & 1 & 0 & 0.94780 & -5.81510 & 2.11780 \\
\hline
\end{tabular}




$\begin{array}{llllll}79 & 1 & 0 & 0.21950 & -3.83280 & 3.42660 \\ 80 & 1 & 0 & 0.53550 & -1.55410 & 2.50430 \\ 81 & 1 & 0 & -2.28670 & -3.22230 & 1.04100 \\ 82 & 1 & 0 & -1.95100 & -5.50690 & 0.13410 \\ 83 & 1 & 0 & -0.94850 & -5.81510 & -2.11790 \\ 84 & 1 & 0 & -0.21980 & -3.83290 & -3.42660 \\ 85 & 1 & 0 & -0.53550 & -1.55410 & -2.50430 \\ - & 1 & & \end{array}$




\section{Free Energy and Geometry for $13-\mathrm{S}$}

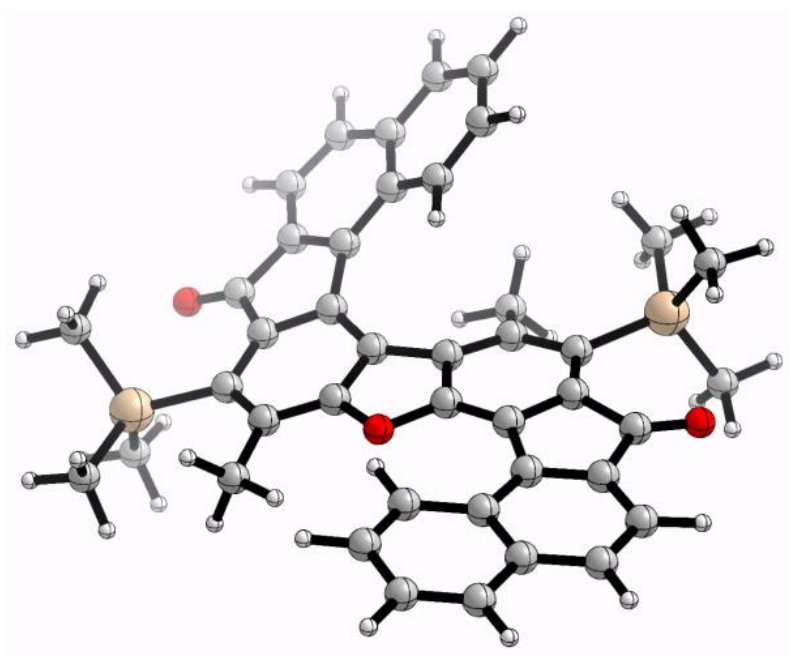

Sum of electronic and thermal free energies: -2425.545549 a.u.

Number of imaginary frequencies: 0

\begin{tabular}{|c|c|c|c|c|c|}
\hline \multirow{2}{*}{$\begin{array}{l}\text { Center } \\
\text { Number }\end{array}$} & \multirow{2}{*}{$\begin{array}{l}\text { Atomic } \\
\text { Number }\end{array}$} & \multirow{2}{*}{$\begin{array}{c}\text { Atomic } \\
\text { Type }\end{array}$} & \multicolumn{3}{|c|}{ Coordinates (Ångstroms) } \\
\hline & & & $\mathrm{X}$ & $\mathrm{Y}$ & $\mathrm{Z}$ \\
\hline 1 & 6 & 0 & -1.00990 & 0.19710 & 0.10160 \\
\hline 2 & 6 & 0 & -0.75400 & 1.58260 & 0.04670 \\
\hline 3 & 6 & 0 & -1.68610 & 2.60950 & 0.12660 \\
\hline 4 & 6 & 0 & -3.04140 & 2.22580 & 0.29350 \\
\hline 5 & 6 & 0 & -3.31550 & 0.84800 & 0.23470 \\
\hline 6 & 6 & 0 & -2.35370 & -0.16760 & 0.02680 \\
\hline 7 & 6 & 0 & -3.06300 & -1.45270 & -0.23120 \\
\hline 8 & 6 & 0 & -4.38800 & -1.29380 & 0.13030 \\
\hline 9 & 6 & 0 & -4.62940 & 0.14610 & 0.43480 \\
\hline 10 & 6 & 0 & -5.33410 & -2.32700 & 0.04800 \\
\hline 11 & 6 & 0 & -4.92210 & -3.54150 & -0.44700 \\
\hline 12 & 6 & 0 & -3.60560 & -3.71040 & -0.95830 \\
\hline 13 & 6 & 0 & -2.65700 & -2.63950 & -0.89690 \\
\hline 14 & 6 & 0 & -1.18480 & 4.03030 & 0.07540 \\
\hline 15 & 8 & 0 & -5.69100 & 0.63010 & 0.77120 \\
\hline 16 & 8 & 0 & 0.59060 & 1.82070 & -0.07070 \\
\hline 17 & 6 & 0 & 2.13230 & -1.98010 & 0.61150 \\
\hline 18 & 6 & 0 & 0.73930 & -1.70240 & 0.63300 \\
\hline 19 & 6 & 0 & 0.30510 & -0.43610 & 0.21170 \\
\hline 20 & 6 & 0 & 1.22710 & 0.61670 & 0.01160 \\
\hline 21 & 6 & 0 & 2.59110 & 0.41120 & 0.01610 \\
\hline 22 & 6 & 0 & 2.98950 & -0.91310 & 0.31000 \\
\hline 23 & 6 & 0 & 4.48570 & -0.88470 & 0.44740 \\
\hline
\end{tabular}




\begin{tabular}{|c|c|c|c|c|c|}
\hline 24 & 6 & 0 & 4.90820 & 0.51060 & 0.15980 \\
\hline 25 & 6 & 0 & 3.79780 & 1.28310 & -0.13350 \\
\hline 26 & 6 & 0 & 3.97580 & 2.64280 & -0.51820 \\
\hline 27 & 6 & 0 & 5.31520 & 3.15750 & -0.49380 \\
\hline 28 & 6 & 0 & 6.41390 & 2.32720 & -0.14020 \\
\hline 29 & 6 & 0 & 6.22160 & 1.00430 & 0.16710 \\
\hline 30 & 6 & 0 & -0.24630 & -2.63950 & 1.28690 \\
\hline 31 & 8 & 0 & 5.21920 & -1.79510 & 0.77610 \\
\hline 32 & 6 & 0 & -1.41680 & -2.78230 & -1.57760 \\
\hline 33 & 6 & 0 & -1.10020 & -3.95240 & -2.21870 \\
\hline 34 & 6 & 0 & -2.00260 & -5.04640 & -2.20330 \\
\hline 35 & 6 & 0 & -3.22550 & -4.92350 & -1.59610 \\
\hline 36 & 6 & 0 & 2.93190 & 3.50420 & -0.95610 \\
\hline 37 & 6 & 0 & 3.18970 & 4.80470 & -1.30740 \\
\hline 38 & 6 & 0 & 4.50570 & 5.32310 & -1.24380 \\
\hline 39 & 6 & 0 & 5.54020 & 4.51450 & -0.85210 \\
\hline 40 & 1 & 0 & -6.35820 & -2.15540 & 0.36550 \\
\hline 41 & 1 & 0 & -5.61200 & -4.37840 & -0.51110 \\
\hline 42 & 1 & 0 & -1.58340 & 4.56290 & -0.79220 \\
\hline 43 & 1 & 0 & -1.47480 & 4.58370 & 0.97160 \\
\hline 44 & 1 & 0 & -0.09500 & 4.05260 & 0.01160 \\
\hline 45 & 1 & 0 & 7.40960 & 2.76180 & -0.13800 \\
\hline 46 & 1 & 0 & 7.04710 & 0.34460 & 0.41700 \\
\hline 47 & 1 & 0 & -1.16870 & -2.10900 & 1.53460 \\
\hline 48 & 1 & 0 & -0.50980 & -3.50470 & 0.67710 \\
\hline 49 & 1 & 0 & 0.17970 & -3.01070 & 2.22450 \\
\hline 50 & 1 & 0 & -0.72660 & -1.94610 & -1.60150 \\
\hline 51 & 1 & 0 & -0.15440 & -4.04300 & -2.74480 \\
\hline 52 & 1 & 0 & -1.73030 & -5.97310 & -2.69910 \\
\hline 53 & 1 & 0 & -3.93870 & -5.74330 & -1.61470 \\
\hline 54 & 1 & 0 & 1.92360 & 3.12110 & -1.02870 \\
\hline 55 & 1 & 0 & 2.37720 & 5.44180 & -1.64370 \\
\hline 56 & 1 & 0 & 4.69230 & 6.35680 & -1.51820 \\
\hline 57 & 1 & 0 & 6.55820 & 4.89320 & -0.81760 \\
\hline 58 & 6 & 0 & 3.70350 & -3.90470 & 2.53480 \\
\hline 59 & 1 & 0 & 2.96870 & -3.79840 & 3.34170 \\
\hline 60 & 1 & 0 & 4.15140 & -4.90160 & 2.62780 \\
\hline 61 & 1 & 0 & 4.48980 & -3.16110 & 2.67980 \\
\hline 62 & 6 & 0 & 3.92640 & -4.16160 & -0.62700 \\
\hline 63 & 1 & 0 & 4.44730 & -5.10980 & -0.44400 \\
\hline 64 & 1 & 0 & 3.28220 & -4.31020 & -1.50240 \\
\hline 65 & 1 & 0 & 4.67610 & -3.40810 & -0.87050 \\
\hline 66 & 6 & 0 & 1.54280 & -5.10760 & 0.81040 \\
\hline 67 & 1 & 0 & 0.90980 & -5.16600 & 1.69970 \\
\hline 68 & 1 & 0 & 0.89730 & -5.04170 & -0.07290 \\
\hline 69 & 1 & 0 & 2.09230 & -6.05560 & 0.73630 \\
\hline 70 & 6 & 0 & -4.02640 & 5.28910 & 0.35350 \\
\hline 71 & 1 & 0 & -3.37000 & 5.65390 & 1.14840 \\
\hline 72 & 1 & 0 & -3.58400 & 5.54770 & -0.61300 \\
\hline 73 & 1 & 0 & -4.97030 & 5.84550 & 0.43440 \\
\hline 74 & 6 & 0 & -5.74040 & 3.21190 & -0.87880 \\
\hline 75 & 1 & 0 & -6.63290 & 3.81890 & -0.68190 \\
\hline
\end{tabular}




\begin{tabular}{|c|c|c|c|c|c|}
\hline 76 & 1 & 0 & -5.30800 & 3.56660 & -1.82200 \\
\hline 77 & 1 & 0 & -6.06000 & 2.17730 & -1.01010 \\
\hline 78 & 6 & 0 & -5.19310 & 3.30390 & 2.25460 \\
\hline 79 & 1 & 0 & -4.46250 & 3.67910 & 2.98110 \\
\hline 80 & 1 & 0 & -6.09530 & 3.92090 & 2.34880 \\
\hline 81 & 1 & 0 & -5.45340 & 2.27760 & 2.51860 \\
\hline 82 & 14 & 0 & 2.85230 & -3.74680 & 0.86570 \\
\hline 83 & 14 & 0 & -4.49850 & 3.46810 & 0.51370 \\
\hline
\end{tabular}




\section{Free Energy and Geometry for $15-\mathrm{S}$}

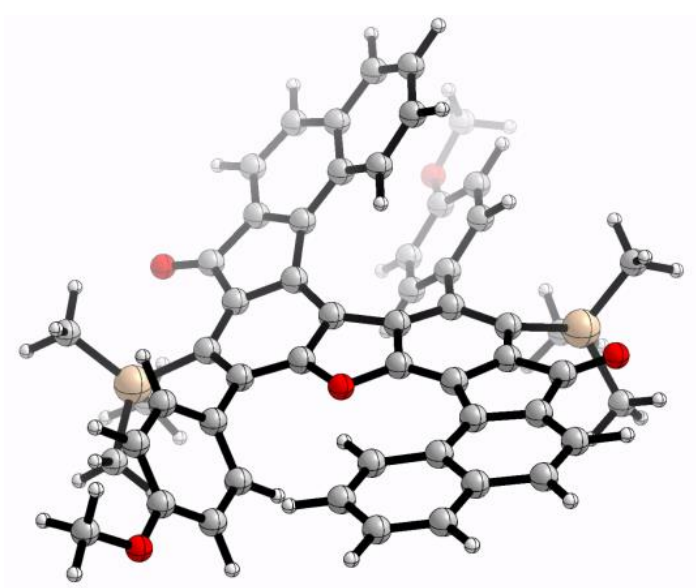

Sum of electronic and thermal free energies: -3037.597288 a.u.

Number of imaginary frequencies: 0

\begin{tabular}{|c|c|c|c|c|c|}
\hline \multirow{2}{*}{$\begin{array}{l}\text { Center } \\
\text { Number }\end{array}$} & \multirow{2}{*}{$\begin{array}{l}\text { Atomic } \\
\text { Number }\end{array}$} & \multirow{2}{*}{$\begin{array}{l}\text { Atomic } \\
\text { Type }\end{array}$} & \multicolumn{3}{|c|}{ Coordinates (Ångstroms) } \\
\hline & & & $X$ & $\mathrm{Y}$ & $\mathrm{Z}$ \\
\hline 1 & 6 & 0 & 0.91810 & 2.70550 & 0.06360 \\
\hline 2 & 6 & 0 & -0.27800 & 3.42450 & -0.13850 \\
\hline 3 & 6 & 0 & 0.04690 & 4.87270 & 0.06150 \\
\hline 4 & 6 & 0 & 1.51760 & 4.94650 & 0.25860 \\
\hline 5 & 6 & 0 & 2.05410 & 3.66830 & 0.25900 \\
\hline 6 & 6 & 0 & 2.27270 & 6.11300 & 0.44680 \\
\hline 7 & 6 & 0 & 3.62570 & 5.98140 & 0.62690 \\
\hline 8 & 6 & 0 & 4.23530 & 4.69770 & 0.62910 \\
\hline 9 & 6 & 0 & 3.45770 & 3.50350 & 0.44690 \\
\hline 10 & 6 & 0 & 5.63980 & 4.58930 & 0.81920 \\
\hline 11 & 6 & 0 & 6.25910 & 3.36770 & 0.83180 \\
\hline 12 & 6 & 0 & 5.49570 & 2.18950 & 0.65140 \\
\hline 13 & 6 & 0 & 4.13820 & 2.25340 & 0.46430 \\
\hline 14 & 6 & 0 & 0.76670 & 1.33050 & 0.04030 \\
\hline 15 & 6 & 0 & -0.50570 & 0.71620 & -0.00730 \\
\hline 16 & 6 & 0 & -1.65460 & 1.47070 & -0.31740 \\
\hline 17 & 6 & 0 & -1.53080 & 2.87760 & -0.44530 \\
\hline 18 & 6 & 0 & -0.22590 & -0.71760 & 0.10320 \\
\hline 19 & 6 & 0 & 1.17280 & -0.83000 & -0.01280 \\
\hline 20 & 8 & 0 & 1.76510 & 0.40150 & 0.04710 \\
\hline 21 & 6 & 0 & 1.89630 & -2.00550 & -0.19380 \\
\hline 22 & 6 & 0 & 1.14880 & -3.19810 & -0.36340 \\
\hline 23 & 6 & 0 & -0.22410 & -3.11080 & -0.07490 \\
\hline 24 & 6 & 0 & -0.90310 & -1.92560 & 0.27980 \\
\hline 25 & 6 & 0 & -2.26100 & -2.28030 & 0.77100 \\
\hline
\end{tabular}




\begin{tabular}{|c|c|c|c|c|c|}
\hline 26 & 6 & 0 & -2.52140 & -3.59170 & 0.41670 \\
\hline 27 & 6 & 0 & -1.25310 & -4.20750 & -0.07170 \\
\hline 28 & 6 & 0 & -3.74460 & -4.22360 & 0.69140 \\
\hline 29 & 6 & 0 & -4.69520 & -3.51690 & 1.39030 \\
\hline 30 & 6 & 0 & -4.39400 & -2.23740 & 1.93600 \\
\hline 31 & 6 & 0 & -3.14170 & -1.60440 & 1.65490 \\
\hline 32 & 6 & 0 & -5.29200 & -1.60210 & 2.83740 \\
\hline 33 & 6 & 0 & -4.93210 & -0.45160 & 3.49300 \\
\hline 34 & 6 & 0 & -3.65770 & 0.12760 & 3.27370 \\
\hline 35 & 6 & 0 & -2.79350 & -0.42170 & 2.36150 \\
\hline 36 & 8 & 0 & -0.73900 & 5.79440 & 0.14270 \\
\hline 37 & 14 & 0 & -2.83000 & 3.97830 & -1.35740 \\
\hline 38 & 14 & 0 & 1.90120 & -4.79680 & -1.12870 \\
\hline 39 & 8 & 0 & -1.08950 & -5.38160 & -0.33440 \\
\hline 40 & 6 & 0 & -3.99600 & 4.87470 & -0.18690 \\
\hline 41 & 6 & 0 & -1.90860 & 5.20970 & -2.46090 \\
\hline 42 & 6 & 0 & -3.82790 & 2.95670 & -2.59440 \\
\hline 43 & 6 & 0 & 3.37920 & -1.93850 & -0.14800 \\
\hline 44 & 6 & 0 & 1.98930 & -6.17810 & 0.14180 \\
\hline 45 & 6 & 0 & 0.89520 & -5.21860 & -2.66600 \\
\hline 46 & 6 & 0 & 3.63350 & -4.53870 & -1.82870 \\
\hline 47 & 6 & 0 & -5.31900 & 0.55620 & -0.02580 \\
\hline 48 & 6 & 0 & -4.09120 & 1.18830 & 0.15250 \\
\hline 49 & 6 & 0 & -2.95200 & 0.78960 & -0.54800 \\
\hline 50 & 6 & 0 & -3.07280 & -0.25900 & -1.46950 \\
\hline 51 & 6 & 0 & -4.28810 & -0.89540 & -1.66780 \\
\hline 52 & 6 & 0 & -5.41540 & -0.50280 & -0.93450 \\
\hline 53 & 6 & 0 & 4.07330 & -2.66130 & 0.82190 \\
\hline 54 & 6 & 0 & 5.46340 & -2.60070 & 0.92080 \\
\hline 55 & 6 & 0 & 6.17750 & -1.79820 & 0.02800 \\
\hline 56 & 6 & 0 & 5.49190 & -1.06580 & -0.95210 \\
\hline 57 & 6 & 0 & 4.11070 & -1.12820 & -1.02900 \\
\hline 58 & 1 & 0 & 1.78180 & 7.08150 & 0.44390 \\
\hline 59 & 1 & 0 & 4.25730 & 6.85320 & 0.77230 \\
\hline 60 & 1 & 0 & 6.21120 & 5.50360 & 0.95520 \\
\hline 61 & 1 & 0 & 7.33250 & 3.29850 & 0.97900 \\
\hline 62 & 1 & 0 & 5.99060 & 1.22240 & 0.65940 \\
\hline 63 & 1 & 0 & 3.57960 & 1.33770 & 0.32740 \\
\hline 64 & 1 & 0 & -3.91830 & -5.24410 & 0.36350 \\
\hline 65 & 1 & 0 & -5.66420 & -3.95720 & 1.60910 \\
\hline 66 & 1 & 0 & -6.25220 & -2.07380 & 3.03040 \\
\hline 67 & 1 & 0 & -5.61500 & 0.00730 & 4.20150 \\
\hline 68 & 1 & 0 & -3.37100 & 1.01870 & 3.82390 \\
\hline 69 & 1 & 0 & -1.82130 & 0.03030 & 2.19000 \\
\hline 70 & 1 & 0 & -4.59740 & 5.59500 & -0.75480 \\
\hline 71 & 1 & 0 & -4.68580 & 4.18700 & 0.31310 \\
\hline 72 & 1 & 0 & -3.43900 & 5.42780 & 0.57520 \\
\hline 73 & 1 & 0 & -0.91410 & 4.84440 & -2.74290 \\
\hline 74 & 1 & 0 & -2.47900 & 5.34750 & -3.38680 \\
\hline 75 & 1 & 0 & -1.78350 & 6.18630 & -1.98910 \\
\hline 76 & 1 & 0 & -4.58870 & 2.30780 & -2.15510 \\
\hline 77 & 1 & 0 & -4.33530 & 3.66720 & -3.25970 \\
\hline
\end{tabular}




$\begin{array}{rrrrrr}78 & 1 & 0 & -3.17260 & 2.33930 & -3.22040 \\ 79 & 1 & 0 & 2.34040 & -7.10050 & -0.33620 \\ 80 & 1 & 0 & 2.70380 & -5.92350 & 0.93330 \\ 81 & 1 & 0 & 1.01800 & -6.37870 & 0.60010 \\ 82 & 1 & 0 & -0.17620 & -5.32130 & -2.49280 \\ 83 & 1 & 0 & 1.05500 & -4.44560 & -3.42750 \\ 84 & 1 & 0 & 1.26320 & -6.16440 & -3.08320 \\ 85 & 1 & 0 & 3.85180 & -5.41460 & -2.45430 \\ 86 & 1 & 0 & 3.68990 & -3.65600 & -2.47480 \\ 87 & 1 & 0 & 4.42200 & -4.46100 & -1.07620 \\ 88 & 1 & 0 & -6.17610 & 0.87950 & 0.55340 \\ 89 & 1 & 0 & -4.01160 & 1.99160 & 0.88060 \\ 90 & 1 & 0 & -2.20490 & -0.57510 & -2.04300 \\ 91 & 1 & 0 & -4.38710 & -1.71170 & -2.37650 \\ 92 & 1 & 0 & 3.51890 & -3.28230 & 1.52190 \\ 93 & 1 & 0 & 5.96970 & -3.17000 & 1.69160 \\ 94 & 1 & 0 & 6.06600 & -0.44840 & -1.63620 \\ 95 & 1 & 0 & 3.59010 & -0.55350 & -1.79040 \\ 96 & 8 & 0 & 7.52450 & -1.65240 & 0.03740 \\ 97 & 8 & 0 & -6.54850 & -1.20700 & -1.16730 \\ 98 & 6 & 0 & -7.69200 & -0.87960 & -0.39600 \\ 99 & 1 & 0 & -8.47360 & -1.57370 & -0.70590 \\ 100 & 1 & 0 & -7.49450 & -1.00540 & 0.67500 \\ 101 & 1 & 0 & -8.02130 & 0.14780 & -0.58790 \\ 102 & 0 & 0 & -25520 & -2.37630 & 1.01340 \\ 103 & 1 & 0 & 9.30380 & -2.12620 & 0.85120 \\ 104 & 1 & 0 & 7.96280 & -2.08090 & 2.02740 \\ 105 & 1 & 0 & -11570 & -3.45660 & 0.89290 \\ --------------------------------------100\end{array}$




\section{Free Energy and Geometry for 17-S}

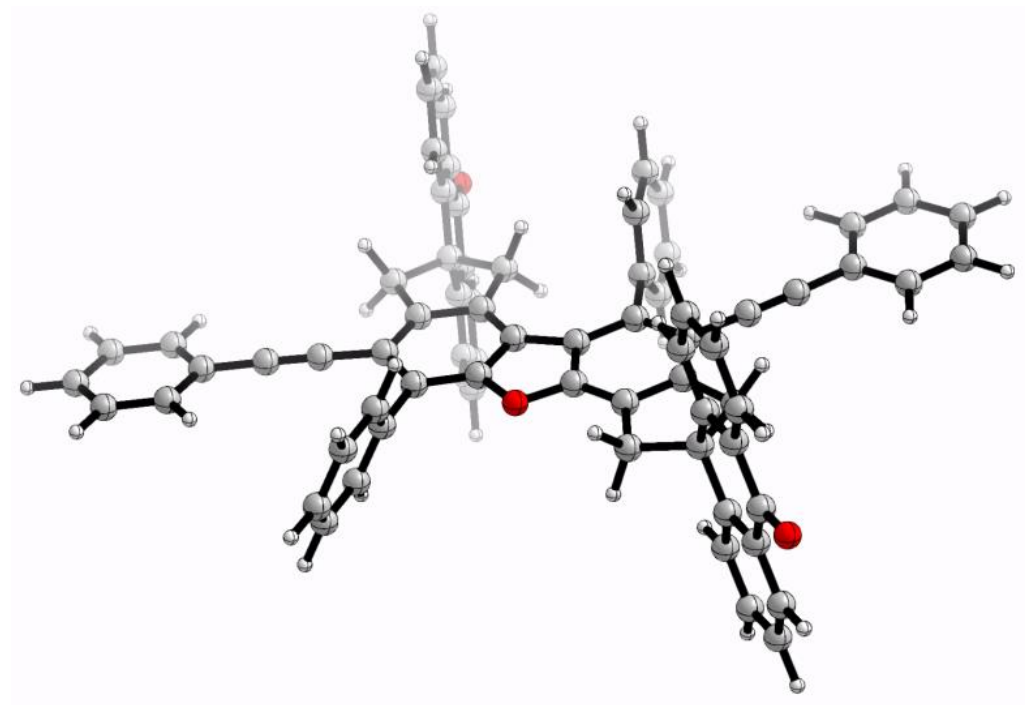

Sum of electronic and thermal free energies: -2994.688265 a.u.

Number of imaginary frequencies: 0

\begin{tabular}{|c|c|c|c|c|c|}
\hline \multirow{2}{*}{$\begin{array}{l}\text { Center } \\
\text { Number }\end{array}$} & \multirow{2}{*}{$\begin{array}{l}\text { Atomic } \\
\text { Number }\end{array}$} & \multirow{2}{*}{$\begin{array}{l}\text { Atomic } \\
\text { Type }\end{array}$} & \multicolumn{3}{|c|}{ Coordinates (Ångstroms) } \\
\hline & & & $X$ & $\mathrm{Y}$ & $\mathrm{Z}$ \\
\hline 1 & 6 & 0 & 0.82330 & -0.23800 & -0.04170 \\
\hline 2 & 6 & 0 & 0.80920 & -1.63690 & -0.00680 \\
\hline 3 & 8 & 0 & -0.46930 & -2.09040 & 0.06500 \\
\hline 4 & 6 & 0 & -1.28710 & -1.01770 & 0.06180 \\
\hline 5 & 6 & 0 & -0.56770 & 0.17700 & -0.01710 \\
\hline 6 & 6 & 0 & -2.67020 & -1.10230 & 0.12340 \\
\hline 7 & 6 & 0 & -3.39660 & 0.08140 & 0.09970 \\
\hline 8 & 6 & 0 & -2.75910 & 1.31380 & 0.01350 \\
\hline 9 & 6 & 0 & -1.33210 & 1.38920 & -0.05140 \\
\hline 10 & 6 & 0 & 2.10020 & 0.36310 & -0.08610 \\
\hline 11 & 6 & 0 & 3.25620 & -0.44400 & -0.12320 \\
\hline 12 & 6 & 0 & 3.19250 & -1.83620 & -0.10700 \\
\hline 13 & 6 & 0 & 1.94100 & -2.48080 & -0.03430 \\
\hline 14 & 6 & 0 & -4.87520 & -0.18310 & 0.17970 \\
\hline 15 & 6 & 0 & -5.00100 & -1.75440 & 0.13260 \\
\hline 16 & 6 & 0 & -3.53700 & -2.32270 & 0.21930 \\
\hline 17 & 6 & 0 & 4.51990 & 0.37740 & -0.19480 \\
\hline 18 & 6 & 0 & 4.04460 & 1.85370 & 0.01680 \\
\hline 19 & 6 & 0 & 2.48270 & 1.82080 & -0.10530 \\
\hline 20 & 6 & 0 & -3.55410 & 2.50970 & -0.01980 \\
\hline 21 & 6 & 0 & -0.67420 & 2.69410 & -0.17580 \\
\hline 22 & 6 & 0 & 1.77170 & -3.94000 & 0.00750 \\
\hline
\end{tabular}




\begin{tabular}{|c|c|c|c|c|c|}
\hline 23 & 6 & 0 & 4.40410 & -2.60240 & -0.17550 \\
\hline 24 & 6 & 0 & 5.39980 & -3.27200 & -0.23100 \\
\hline 25 & 6 & 0 & -4.18210 & 3.53320 & -0.05230 \\
\hline 26 & 6 & 0 & -4.88670 & 4.77570 & -0.09540 \\
\hline 27 & 6 & 0 & 6.56120 & -4.10210 & -0.29430 \\
\hline 28 & 6 & 0 & -5.61660 & -2.16300 & -1.21780 \\
\hline 29 & 6 & 0 & -6.80820 & -2.89520 & -1.29900 \\
\hline 30 & 6 & 0 & -7.53220 & -3.31120 & -0.08240 \\
\hline 31 & 6 & 0 & -6.98400 & -2.95820 & 1.24080 \\
\hline 32 & 6 & 0 & -5.79600 & -2.22720 & 1.35860 \\
\hline 33 & 6 & 0 & 4.42180 & 2.31310 & 1.43920 \\
\hline 34 & 6 & 0 & 5.18540 & 3.46540 & 1.66740 \\
\hline 35 & 6 & 0 & 5.67590 & 4.29090 & 0.54740 \\
\hline 36 & 6 & 0 & 5.36240 & 3.89040 & -0.83670 \\
\hline 37 & 6 & 0 & 4.60610 & 2.74310 & -1.10290 \\
\hline 38 & 6 & 0 & -4.99070 & -1.80370 & -2.43350 \\
\hline 39 & 6 & 0 & -5.53250 & -2.16170 & -3.67050 \\
\hline 40 & 6 & 0 & -6.71420 & -2.88830 & -3.72670 \\
\hline 41 & 6 & 0 & -7.35110 & -3.25420 & -2.54440 \\
\hline 42 & 6 & 0 & -7.68960 & -3.37550 & 2.38200 \\
\hline 43 & 6 & 0 & -7.22020 & -3.06900 & 3.65630 \\
\hline 44 & 6 & 0 & -6.04450 & -2.34360 & 3.79700 \\
\hline 45 & 6 & 0 & -5.34170 & -1.92800 & 2.66380 \\
\hline 46 & 6 & 0 & 5.84510 & 4.69480 & -1.88260 \\
\hline 47 & 6 & 0 & 5.58110 & 4.36600 & -3.20930 \\
\hline 48 & 6 & 0 & 4.83400 & 3.23200 & -3.49780 \\
\hline 49 & 6 & 0 & 4.35240 & 2.43200 & -2.45930 \\
\hline 50 & 6 & 0 & 3.99380 & 1.58510 & 2.57330 \\
\hline 51 & 6 & 0 & 4.31720 & 1.99000 & 3.87080 \\
\hline 52 & 6 & 0 & 5.07560 & 3.13500 & 4.07210 \\
\hline 53 & 6 & 0 & 5.50860 & 3.87140 & 2.97360 \\
\hline 54 & 6 & 0 & 1.20670 & -4.63030 & -1.07540 \\
\hline 55 & 6 & 0 & 1.06030 & -6.02060 & -1.04470 \\
\hline 56 & 6 & 0 & 1.46920 & -6.75560 & 0.07660 \\
\hline 57 & 6 & 0 & 2.03610 & -6.07160 & 1.16090 \\
\hline 58 & 6 & 0 & 2.18020 & -4.68140 & 1.12710 \\
\hline 59 & 6 & 0 & 7.83450 & -3.53760 & -0.20880 \\
\hline 60 & 6 & 0 & 8.96730 & -4.35420 & -0.27000 \\
\hline 61 & 6 & 0 & 8.83800 & -5.74550 & -0.41020 \\
\hline 62 & 6 & 0 & 7.55190 & -6.30060 & -0.50380 \\
\hline 63 & 6 & 0 & 6.42000 & -5.48330 & -0.44270 \\
\hline 64 & 6 & 0 & -6.27820 & 4.79920 & 0.00490 \\
\hline 65 & 6 & 0 & -6.96190 & 6.01780 & -0.03680 \\
\hline 66 & 6 & 0 & -6.26090 & 7.22530 & -0.18620 \\
\hline 67 & 6 & 0 & -4.86040 & 7.18920 & -0.27750 \\
\hline 68 & 6 & 0 & -4.17790 & 5.97060 & -0.23550 \\
\hline 69 & 6 & 0 & -0.41150 & 3.47680 & 0.95940 \\
\hline 70 & 6 & 0 & 0.15270 & 4.75030 & 0.83530 \\
\hline 71 & 6 & 0 & 0.46040 & 5.27350 & -0.42890 \\
\hline 72 & 6 & 0 & 0.17320 & 4.50560 & -1.56650 \\
\hline 73 & 6 & 0 & -0.39000 & 3.23200 & -1.44050 \\
\hline 74 & 8 & 0 & -8.58120 & -3.94180 & -0.17020 \\
\hline
\end{tabular}




\begin{tabular}{|c|c|c|c|c|c|}
\hline 75 & 8 & 0 & 6.34090 & 5.29880 & 0.76480 \\
\hline 76 & 1 & 0 & -5.39620 & 0.30230 & -0.65410 \\
\hline 77 & 1 & 0 & -5.26420 & 0.25110 & 1.10780 \\
\hline 78 & 1 & 0 & -3.29810 & -3.02030 & -0.59160 \\
\hline 79 & 1 & 0 & -3.32170 & -2.83560 & 1.16310 \\
\hline 80 & 1 & 0 & 4.98980 & 0.20790 & -1.17000 \\
\hline 81 & 1 & 0 & 5.23480 & 0.05890 & 0.57300 \\
\hline 82 & 1 & 0 & 2.12780 & 2.25180 & -1.04360 \\
\hline 83 & 1 & 0 & 2.00850 & 2.34180 & 0.72830 \\
\hline 84 & 1 & 0 & -4.06310 & -1.23400 & -2.43660 \\
\hline 85 & 1 & 0 & -5.02860 & -1.87100 & -4.58940 \\
\hline 86 & 1 & 0 & -7.14110 & -3.17050 & -4.68540 \\
\hline 87 & 1 & 0 & -8.27770 & -3.82410 & -2.59380 \\
\hline 88 & 1 & 0 & -8.61210 & -3.94460 & 2.27750 \\
\hline 89 & 1 & 0 & -7.77220 & -3.39670 & 4.53350 \\
\hline 90 & 1 & 0 & -5.67100 & -2.09990 & 4.78890 \\
\hline 91 & 1 & 0 & -4.42380 & -1.36070 & 2.81500 \\
\hline 92 & 1 & 0 & 6.43100 & 5.58600 & -1.66220 \\
\hline 93 & 1 & 0 & 5.95850 & 4.99500 & -4.01140 \\
\hline 94 & 1 & 0 & 4.62340 & 2.96800 & -4.53140 \\
\hline 95 & 1 & 0 & 3.76490 & 1.55390 & -2.72620 \\
\hline 96 & 1 & 0 & 3.39470 & 0.68290 & 2.46670 \\
\hline 97 & 1 & 0 & 3.97450 & 1.40800 & 4.72320 \\
\hline 98 & 1 & 0 & 5.33100 & 3.45600 & 5.07850 \\
\hline 99 & 1 & 0 & 6.10300 & 4.76930 & 3.13660 \\
\hline 100 & 1 & 0 & 0.87860 & -4.08380 & -1.95800 \\
\hline 101 & 1 & 0 & 0.62260 & -6.52730 & -1.90390 \\
\hline 102 & 1 & 0 & 2.36820 & -6.61950 & 2.04170 \\
\hline 103 & 1 & 0 & 2.62000 & -4.17580 & 1.98530 \\
\hline 104 & 1 & 0 & 7.95390 & -2.46240 & -0.09590 \\
\hline 105 & 1 & 0 & 9.95520 & -3.89960 & -0.20560 \\
\hline 106 & 1 & 0 & 7.42560 & -7.37600 & -0.62370 \\
\hline 107 & 1 & 0 & 5.43010 & -5.93010 & -0.51360 \\
\hline 108 & 1 & 0 & -6.83830 & 3.87350 & 0.11720 \\
\hline 109 & 1 & 0 & -8.04810 & 6.02130 & 0.04610 \\
\hline 110 & 1 & 0 & -4.29320 & 8.11340 & -0.38370 \\
\hline 111 & 1 & 0 & -3.09240 & 5.96040 & -0.31130 \\
\hline 112 & 1 & 0 & -0.65170 & 3.09730 & 1.95130 \\
\hline 113 & 1 & 0 & 0.34820 & 5.33530 & 1.73340 \\
\hline 114 & 1 & 0 & 0.38440 & 4.89840 & -2.56050 \\
\hline 115 & 1 & 0 & -0.61510 & 2.66020 & -2.33930 \\
\hline 116 & 1 & 0 & 9.70530 & -6.36900 & -0.47290 \\
\hline 117 & 1 & 0 & -6.78230 & 8.15950 & -0.20170 \\
\hline 118 & 1 & 0 & 1.37870 & -7.82160 & 0.09580 \\
\hline 119 & 1 & 0 & 0.87020 & 6.25730 & -0.52540 \\
\hline
\end{tabular}


Free Energy and Geometry for 19-S (cis)

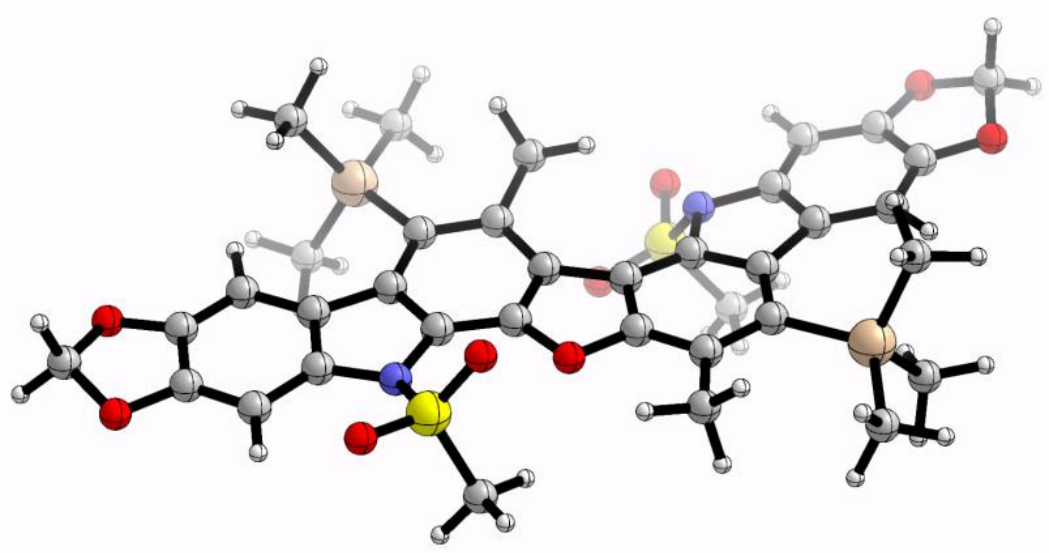

Sum of electronic and thermal free energies: -3554.867158 a.u.

Number of imaginary frequencies: 0

\begin{tabular}{|c|c|c|c|c|c|}
\hline \multirow{2}{*}{$\begin{array}{l}\text { Center } \\
\text { Number }\end{array}$} & \multirow{2}{*}{$\begin{array}{l}\text { Atomic } \\
\text { Number }\end{array}$} & \multirow{2}{*}{$\begin{array}{l}\text { Atomic } \\
\text { Type }\end{array}$} & \multicolumn{3}{|c|}{ Coordinates (Ångstroms) } \\
\hline & & & $\mathrm{X}$ & Y & $\mathrm{Z}$ \\
\hline 1 & 6 & 0 & -0.43050 & -0.30730 & -0.15030 \\
\hline 2 & 6 & 0 & -1.25670 & 0.80740 & 0.00290 \\
\hline 3 & 8 & 0 & -0.55850 & 1.96270 & 0.15100 \\
\hline 4 & 6 & 0 & 0.76790 & 1.62530 & 0.08390 \\
\hline 5 & 6 & 0 & 0.92470 & 0.23870 & -0.02830 \\
\hline 6 & 6 & 0 & 1.77420 & 2.59210 & 0.08030 \\
\hline 7 & 6 & 0 & 3.10390 & 2.14790 & -0.02400 \\
\hline 8 & 6 & 0 & 3.32290 & 0.74020 & -0.07820 \\
\hline 9 & 6 & 0 & 2.25930 & -0.18410 & 0.00650 \\
\hline 10 & 6 & 0 & -0.99460 & -1.57370 & -0.44190 \\
\hline 11 & 6 & 0 & -2.38720 & -1.74040 & -0.37300 \\
\hline 12 & 6 & 0 & -3.20680 & -0.58660 & -0.16110 \\
\hline 13 & 6 & 0 & -2.63830 & 0.69290 & -0.02840 \\
\hline 14 & 7 & 0 & 2.75310 & -1.51760 & 0.04390 \\
\hline 15 & 6 & 0 & 4.15760 & -1.42370 & -0.17630 \\
\hline 16 & 6 & 0 & 4.54380 & -0.07490 & -0.24200 \\
\hline 17 & 7 & 0 & -3.63450 & 1.67220 & 0.12840 \\
\hline 18 & 6 & 0 & -4.88350 & 1.01090 & 0.08770 \\
\hline 19 & 6 & 0 & -4.65730 & -0.37220 & -0.08760 \\
\hline 20 & 6 & 0 & 5.90150 & 0.23190 & -0.48810 \\
\hline 21 & 6 & 0 & 6.75690 & -0.83430 & -0.61880 \\
\hline 22 & 6 & 0 & 6.34010 & -2.16650 & -0.53220 \\
\hline 23 & 6 & 0 & 5.02830 & -2.51390 & -0.31370 \\
\hline 24 & 6 & 0 & -5.76970 & -1.24670 & -0.15880 \\
\hline 25 & 6 & 0 & -7.00960 & -0.68040 & -0.03350 \\
\hline
\end{tabular}




\begin{tabular}{|c|c|c|c|c|c|}
\hline 26 & 6 & 0 & -7.19840 & 0.69060 & 0.17010 \\
\hline 27 & 6 & 0 & -6.15860 & 1.58220 & 0.24700 \\
\hline 28 & 8 & 0 & 7.41590 & -2.98770 & -0.68430 \\
\hline 29 & 6 & 0 & 8.47480 & -2.14360 & -1.14200 \\
\hline 30 & 8 & 0 & 8.10820 & -0.80270 & -0.82250 \\
\hline 31 & 8 & 0 & -8.52980 & 0.94620 & 0.30970 \\
\hline 32 & 6 & 0 & -9.18950 & -0.25610 & -0.09260 \\
\hline 33 & 8 & 0 & -8.22740 & -1.30540 & -0.02320 \\
\hline 34 & 6 & 0 & 1.33990 & 4.03720 & 0.13390 \\
\hline 35 & 14 & 0 & 4.59820 & 3.33720 & 0.00080 \\
\hline 36 & 6 & 0 & -0.08850 & -2.67240 & -0.94330 \\
\hline 37 & 14 & 0 & -3.21220 & -3.45870 & -0.45860 \\
\hline 38 & 16 & 0 & -3.38770 & 3.31100 & -0.28190 \\
\hline 39 & 16 & 0 & 2.32930 & -2.44910 & 1.42780 \\
\hline 40 & 8 & 0 & 0.95760 & -2.11590 & 1.76700 \\
\hline 41 & 8 & 0 & 2.69030 & -3.82220 & 1.11230 \\
\hline 42 & 6 & 0 & 3.38470 & -1.83130 & 2.72220 \\
\hline 43 & 6 & 0 & 5.72540 & 2.79670 & 1.42190 \\
\hline 44 & 6 & 0 & 5.40220 & 3.31370 & -1.70820 \\
\hline 45 & 6 & 0 & 4.25250 & 5.14790 & 0.38580 \\
\hline 46 & 6 & 0 & -4.16770 & -3.68040 & 1.16230 \\
\hline 47 & 6 & 0 & -4.26360 & -3.56440 & -2.02510 \\
\hline 48 & 6 & 0 & -2.09630 & -4.97640 & -0.49160 \\
\hline 49 & 8 & 0 & -2.41000 & 3.36060 & -1.35310 \\
\hline 50 & 8 & 0 & -4.70360 & 3.89170 & -0.48880 \\
\hline 51 & 6 & 0 & -2.70210 & 3.97370 & 1.21200 \\
\hline 52 & 1 & 0 & 6.28780 & 1.23760 & -0.57410 \\
\hline 53 & 1 & 0 & 4.69100 & -3.54140 & -0.26140 \\
\hline 54 & 1 & 0 & -5.68230 & -2.31470 & -0.29520 \\
\hline 55 & 1 & 0 & -6.31930 & 2.63780 & 0.40790 \\
\hline 56 & 1 & 0 & 9.39630 & -2.40360 & -0.62200 \\
\hline 57 & 1 & 0 & 8.57690 & -2.24770 & -2.22860 \\
\hline 58 & 1 & 0 & -10.00960 & -0.46620 & 0.59350 \\
\hline 59 & 1 & 0 & -9.54130 & -0.14730 & -1.12550 \\
\hline 60 & 1 & 0 & 1.86710 & 4.63540 & -0.61080 \\
\hline 61 & 1 & 0 & 0.27080 & 4.11890 & -0.07650 \\
\hline 62 & 1 & 0 & 1.52470 & 4.48050 & 1.11780 \\
\hline 63 & 1 & 0 & -0.52490 & -3.13990 & -1.83010 \\
\hline 64 & 1 & 0 & 0.87880 & -2.26400 & -1.23850 \\
\hline 65 & 1 & 0 & 0.09000 & -3.45420 & -0.20220 \\
\hline 66 & 1 & 0 & 3.05050 & -2.31930 & 3.64120 \\
\hline 67 & 1 & 0 & 4.42290 & -2.08540 & 2.50810 \\
\hline 68 & 1 & 0 & 3.24280 & -0.75020 & 2.79420 \\
\hline 69 & 1 & 0 & 5.42880 & 3.35220 & 2.31970 \\
\hline 70 & 1 & 0 & 5.67770 & 1.73190 & 1.66380 \\
\hline 71 & 1 & 0 & 6.77220 & 3.04980 & 1.21460 \\
\hline 72 & 1 & 0 & 6.46160 & 3.59230 & -1.65530 \\
\hline 73 & 1 & 0 & 5.32770 & 2.35060 & -2.22110 \\
\hline 74 & 1 & 0 & 4.89870 & 4.05720 & -2.33750 \\
\hline 75 & 1 & 0 & 5.23800 & 5.61530 & 0.51780 \\
\hline 76 & 1 & 0 & 3.74060 & 5.68980 & -0.41360 \\
\hline 77 & 1 & 0 & 3.69980 & 5.29240 & 1.31900 \\
\hline
\end{tabular}




\begin{tabular}{|c|c|c|c|c|c|}
\hline 78 & 1 & 0 & -3.50010 & -4.17350 & 1.87910 \\
\hline 79 & 1 & 0 & -4.50870 & -2.74890 & 1.62130 \\
\hline 80 & 1 & 0 & -5.03960 & -4.33240 & 1.02850 \\
\hline 81 & 1 & 0 & -5.05620 & -4.31570 & -1.92390 \\
\hline 82 & 1 & 0 & -4.72670 & -2.61720 & -2.31550 \\
\hline 83 & 1 & 0 & -3.61780 & -3.87980 & -2.85370 \\
\hline 84 & 1 & 0 & -2.77100 & -5.83860 & -0.39630 \\
\hline 85 & 1 & 0 & -1.52680 & -5.10650 & -1.41520 \\
\hline 86 & 1 & 0 & -1.40520 & -5.01460 & 0.35610 \\
\hline 87 & 1 & 0 & -2.50230 & 5.03180 & 1.02320 \\
\hline 88 & 1 & 0 & -3.44660 & 3.85610 & 2.00130 \\
\hline 89 & 1 & 0 & -1.78030 & 3.44330 & 1.45100 \\
\hline
\end{tabular}




\section{Free Energy and Geometry for 19-S (trans)}

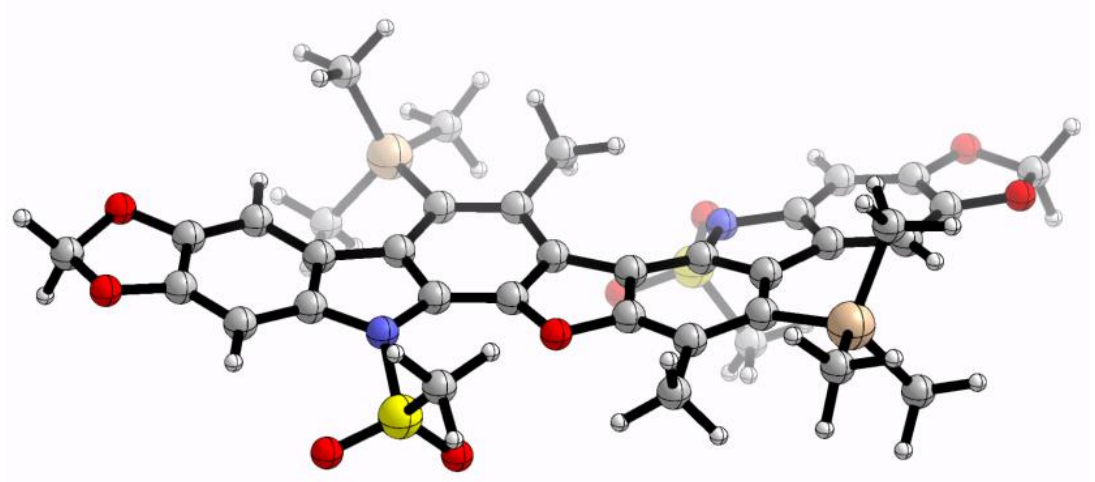

Sum of electronic and thermal free energies: -3554.868490 a.u.

Number of imaginary frequencies: 0

\begin{tabular}{|c|c|c|c|c|c|}
\hline \multirow{2}{*}{$\begin{array}{l}\text { Center } \\
\text { Number }\end{array}$} & \multirow{2}{*}{$\begin{array}{l}\text { Atomic } \\
\text { Number }\end{array}$} & \multirow{2}{*}{$\begin{array}{c}\text { Atomic } \\
\text { Type }\end{array}$} & \multicolumn{3}{|c|}{ Coordinates (Ångstroms) } \\
\hline & & & $X$ & $\mathrm{Y}$ & $\mathrm{Z}$ \\
\hline 1 & 6 & 0 & -0.42870 & -0.32890 & -0.08100 \\
\hline 2 & 6 & 0 & -1.25720 & 0.78140 & 0.09300 \\
\hline 3 & 8 & 0 & -0.56550 & 1.94880 & 0.16360 \\
\hline 4 & 6 & 0 & 0.75960 & 1.61720 & 0.05630 \\
\hline 5 & 6 & 0 & 0.92480 & 0.23010 & -0.02800 \\
\hline 6 & 6 & 0 & 1.75730 & 2.59070 & -0.00330 \\
\hline 7 & 6 & 0 & 3.07510 & 2.15500 & -0.22180 \\
\hline 8 & 6 & 0 & 3.31270 & 0.74910 & -0.19090 \\
\hline 9 & 6 & 0 & 2.26440 & -0.18100 & -0.01800 \\
\hline 10 & 6 & 0 & -0.98930 & -1.59490 & -0.38090 \\
\hline 11 & 6 & 0 & -2.38410 & -1.75940 & -0.35220 \\
\hline 12 & 6 & 0 & -3.20410 & -0.60650 & -0.14470 \\
\hline 13 & 6 & 0 & -2.63760 & 0.65780 & 0.09110 \\
\hline 14 & 7 & 0 & 2.77680 & -1.50300 & 0.08380 \\
\hline 15 & 6 & 0 & 4.18000 & -1.40210 & -0.14220 \\
\hline 16 & 6 & 0 & 4.54580 & -0.05390 & -0.29150 \\
\hline 17 & 7 & 0 & -3.63280 & 1.64610 & 0.17290 \\
\hline 18 & 6 & 0 & -4.87730 & 1.00910 & -0.03020 \\
\hline 19 & 6 & 0 & -4.64950 & -0.36850 & -0.23680 \\
\hline 20 & 6 & 0 & 5.90930 & 0.26400 & -0.48850 \\
\hline 21 & 6 & 0 & 6.78790 & -0.79060 & -0.51140 \\
\hline 22 & 6 & 0 & 6.38840 & -2.12320 & -0.36630 \\
\hline 23 & 6 & 0 & 5.07460 & -2.48180 & -0.18220 \\
\hline 24 & 6 & 0 & -5.74640 & -1.21000 & -0.54380 \\
\hline 25 & 6 & 0 & -6.98000 & -0.61820 & -0.59720 \\
\hline 26 & 6 & 0 & -7.17300 & 0.75180 & -0.38580 \\
\hline
\end{tabular}




\begin{tabular}{|c|c|c|c|c|c|}
\hline 27 & 6 & 0 & -6.14310 & 1.61550 & -0.10970 \\
\hline 28 & 8 & 0 & 7.47430 & -2.93630 & -0.48860 \\
\hline 29 & 6 & 0 & 8.60670 & -2.06590 & -0.43870 \\
\hline 30 & 8 & 0 & 8.13680 & -0.75080 & -0.72820 \\
\hline 31 & 8 & 0 & -8.49190 & 1.05150 & -0.55450 \\
\hline 32 & 6 & 0 & -9.16260 & -0.20970 & -0.59350 \\
\hline 33 & 8 & 0 & -8.18220 & -1.19540 & -0.90640 \\
\hline 34 & 6 & 0 & 1.32280 & 4.02700 & 0.16170 \\
\hline 35 & 14 & 0 & 4.49510 & 3.35820 & -0.64640 \\
\hline 36 & 6 & 0 & -0.07530 & -2.69120 & -0.87420 \\
\hline 37 & 14 & 0 & -3.19310 & -3.48400 & -0.46280 \\
\hline 38 & 16 & 0 & -3.41030 & 3.10960 & 1.01830 \\
\hline 39 & 16 & 0 & 2.36170 & -2.38830 & 1.50130 \\
\hline 40 & 8 & 0 & 0.98200 & -2.07110 & 1.82000 \\
\hline 41 & 8 & 0 & 2.75090 & -3.76520 & 1.24120 \\
\hline 42 & 6 & 0 & 3.39600 & -1.69660 & 2.77480 \\
\hline 43 & 6 & 0 & 5.74380 & 3.36610 & 0.77020 \\
\hline 44 & 6 & 0 & 5.18840 & 2.80850 & -2.31930 \\
\hline 45 & 6 & 0 & 4.02040 & 5.15680 & -0.94040 \\
\hline 46 & 6 & 0 & -4.38450 & -3.63570 & 1.00280 \\
\hline 47 & 6 & 0 & -3.99980 & -3.70840 & -2.15580 \\
\hline 48 & 6 & 0 & -2.05260 & -4.96340 & -0.21190 \\
\hline 49 & 8 & 0 & -4.73120 & 3.56540 & 1.41670 \\
\hline 50 & 8 & 0 & -2.39370 & 2.88260 & 2.02830 \\
\hline 51 & 6 & 0 & -2.78770 & 4.18510 & -0.24510 \\
\hline 52 & 1 & 0 & 6.28120 & 1.26960 & -0.62410 \\
\hline 53 & 1 & 0 & 4.75410 & -3.51090 & -0.08060 \\
\hline 54 & 1 & 0 & -5.64950 & -2.26860 & -0.73940 \\
\hline 55 & 1 & 0 & -6.30310 & 2.67450 & 0.03250 \\
\hline 56 & 1 & 0 & 9.03650 & -2.08800 & 0.56980 \\
\hline 57 & 1 & 0 & 9.33090 & -2.36950 & -1.19390 \\
\hline 58 & 1 & 0 & -9.59470 & -0.42010 & 0.39230 \\
\hline 59 & 1 & 0 & -9.92390 & -0.19130 & -1.37280 \\
\hline 60 & 1 & 0 & 1.17110 & 4.52440 & -0.80240 \\
\hline 61 & 1 & 0 & 0.37740 & 4.06830 & 0.70940 \\
\hline 62 & 1 & 0 & 2.05810 & 4.60010 & 0.72780 \\
\hline 63 & 1 & 0 & 0.13870 & -3.44530 & -0.11360 \\
\hline 64 & 1 & 0 & -0.52150 & -3.19610 & -1.73570 \\
\hline 65 & 1 & 0 & 0.87630 & -2.27170 & -1.20490 \\
\hline 66 & 1 & 0 & 3.06940 & -2.15670 & 3.71070 \\
\hline 67 & 1 & 0 & 4.44110 & -1.93300 & 2.57460 \\
\hline 68 & 1 & 0 & 3.22630 & -0.61760 & 2.80410 \\
\hline 69 & 1 & 0 & 5.40810 & 4.08630 & 1.52590 \\
\hline 70 & 1 & 0 & 5.85720 & 2.39930 & 1.26870 \\
\hline 71 & 1 & 0 & 6.73300 & 3.69020 & 0.42500 \\
\hline 72 & 1 & 0 & 6.25060 & 3.06510 & -2.41390 \\
\hline 73 & 1 & 0 & 5.07780 & 1.74160 & -2.52920 \\
\hline 74 & 1 & 0 & 4.65090 & 3.35480 & -3.10370 \\
\hline 75 & 1 & 0 & 4.91270 & 5.63630 & -1.36520 \\
\hline 76 & 1 & 0 & 3.21460 & 5.27050 & -1.67210 \\
\hline 77 & 1 & 0 & 3.75330 & 5.70910 & -0.03570 \\
\hline 78 & 1 & 0 & -4.76910 & -2.68640 & 1.38280 \\
\hline
\end{tabular}




\begin{tabular}{|c|c|c|c|c|c|}
\hline 79 & 1 & 0 & -5.24160 & -4.27390 & 0.75540 \\
\hline 80 & 1 & 0 & -3.84420 & -4.12200 & 1.82380 \\
\hline 81 & 1 & 0 & -4.74240 & -4.51510 & -2.13490 \\
\hline 82 & 1 & 0 & -4.48570 & -2.80670 & -2.53960 \\
\hline 83 & 1 & 0 & -3.22580 & -3.99390 & -2.87850 \\
\hline 84 & 1 & 0 & -2.71110 & -5.83190 & -0.07540 \\
\hline 85 & 1 & 0 & -1.38880 & -5.18100 & -1.05200 \\
\hline 86 & 1 & 0 & -1.44870 & -4.87210 & 0.69730 \\
\hline 87 & 1 & 0 & -2.59620 & 5.15240 & 0.22680 \\
\hline 88 & 1 & 0 & -1.86750 & 3.76100 & -0.64770 \\
\hline 89 & 1 & 0 & -3.55500 & 4.27600 & -1.01630 \\
\hline
\end{tabular}




\section{X-ray data for $11-\mathrm{U}$ and $17-\mathrm{S}$}

\section{Data for 11-U (CCDC Deposition Number 2094221)}

\section{Data collection}

A crystal (approximate dimensions $0.100 \times 0.080 \times 0.020 \mathrm{~mm}^{3}$ ) was placed onto the tip of a $50 \mu \mathrm{m}$ diameter MiTeGen Dual-Thickness Micro-loop and mounted on a Bruker PHOTON-III CPAD diffractometer for a data collection at 125(2) $\mathrm{K} .^{22}$ A preliminary set of cell constants was calculated from reflections harvested from three sets of frames. These initial sets of frames were oriented such that orthogonal wedges of reciprocal space were surveyed. This produced an initial orientation matrix determined from 500 reflections. The data collection was carried out using CuK $\alpha$ radiation (parabolic mirrors) with a frame time of 60 seconds and a detector distance of $4.0 \mathrm{~cm}$. A strategy program was used to assure complete coverage of all unique data to a resolution of $0.79 \AA$. All major sections of frames were collected with $3.0^{\circ}$ steps in $\omega$ or $\phi$ at different detector positions in $2 \theta$. The reflections were streaky so a wider than usual frame width was selected. The intensity data were corrected for absorption and decay (SADABS). ${ }^{23}$ Final cell constants were calculated from 2941 strong reflections from the actual data collection after integration (SAINT). ${ }^{24}$ Please refer to Table S3 for additional crystal and refinement information.

\section{Structure solution and refinement}

The structure was solved using SHELXT 2014/5 (Sheldrick, 2014) ${ }^{25}$ and refined using SHELXL-2018/3 (Sheldrick, 2018). ${ }^{25}$ The space group P-1 was determined based on systematic absences and intensity statistics. A direct-methods solution was calculated which provided most non-hydrogen atoms from the E-map. Full-matrix least squares / difference Fourier cycles were performed which located the remaining non-hydrogen atoms. All non-hydrogen atoms were refined with anisotropic displacement parameters. All hydrogen atoms were placed in ideal positions and refined as riding atoms with relative isotropic displacement parameters. The final full matrix least squares refinement converged to $R 1=0.0581$ and $w R 2=0.1291\left(F^{2}\right.$, obs. data $)$.

Data collection and structure solution were conducted at the X-Ray Crystallographic Laboratory, 192 Kolthoff Hall, Department of Chemistry, University of Minnesota. All calculations were performed using Pentium computers using the current SHELXTL suite of programs.

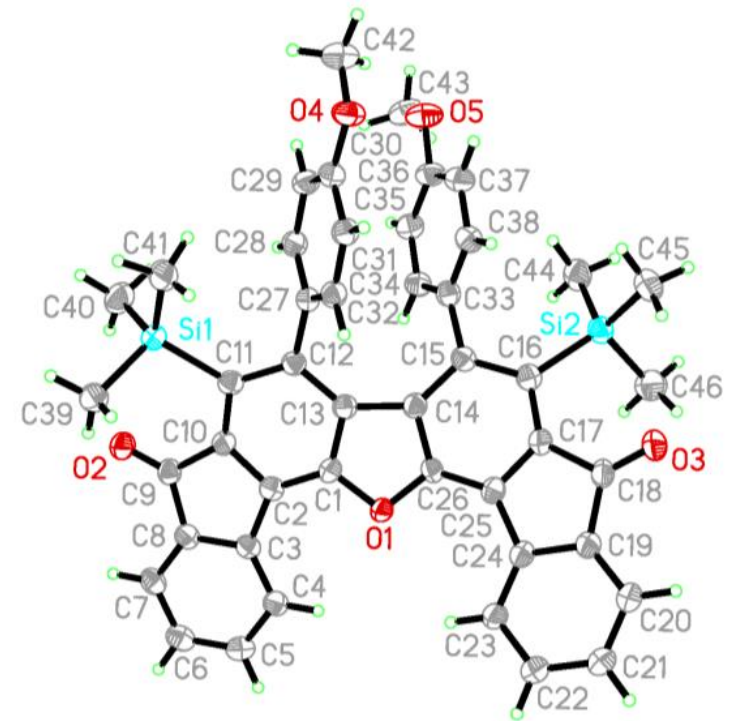


Table S3: Crystal data and structure refinement for $21070 z$ (11-U)

Identification code

Empirical formula

Formula weight

Temperature

Wavelength

Crystal system

Space group

Unit cell dimensions

Volume

Z

Density (calculated)

Absorption coefficient

$F(000)$

Crystal color, morphology

Crystal size

Theta range for data collection

Index ranges

Reflections collected

Independent reflections

Observed reflections

Completeness to theta $=67.684^{\circ}$

Absorption correction

Max. and min. transmission

Refinement method

Data / restraints / parameters

Goodness-of-fit on $F^{2}$

Final $R$ indices $[I>2 \operatorname{sigma}(I)]$

$R$ indices (all data)

Largest diff. peak and hole
$21070 z$

$\mathrm{C}_{46} \mathrm{H}_{40} \mathrm{O}_{5} \mathrm{Si}_{2}$

728.96

125(2) K

$1.54184 \AA$

Triclinic

P-1

$a=12.534(5) \AA$

$\alpha=95.09(3)^{\circ}$

$b=13.268(5) \AA$

$\beta=105.15(3)^{\circ}$

$c=13.552(6) \AA$

$\gamma=114.44(2)^{\circ}$

2

$1.254 \mathrm{Mg} / \mathrm{m}^{3}$

$1.204 \mathrm{~mm}^{-1}$

768

Yellow, Plate

$0.100 \times 0.080 \times 0.020 \mathrm{~mm}^{3}$

3.467 to $75.292^{\circ}$

$-15 \leq h \leq 15,-15 \leq k \leq 16,-16 \leq l \leq 16$

56564

$7767[R($ int $)=0.0829]$

5860

$98.6 \%$

Multi-scan

0.7538 and 0.6402

Full-matrix least-squares on $F^{2}$

7767 / 0 / 486

1.057

$R 1=0.0581, w R 2=0.1291$

$R 1=0.0824, w R 2=0.1448$

0.264 and -0.474 e. $\AA^{-3}$ 


\section{Data for 17-S (CCDC Deposition Number 2094224)}

\section{Data collection}

A crystal (approximate dimensions $0.200 \times 0.200 \times 0.150 \mathrm{~mm}^{3}$ ) was placed onto the tip of a $200 \mu \mathrm{m}$ diameter MiTeGen Double Thickness Micro-loop and mounted on a Bruker PHOTON-III CPAD diffractometer for a data collection at 125(2) $\mathrm{K} .^{22}$ A preliminary set of cell constants was calculated from reflections harvested from two sets of frames. These initial sets of frames were oriented such that orthogonal wedges of reciprocal space were surveyed. This produced an initial orientation matrix determined from 849 reflections. The data collection was carried out using MoK $\alpha$ radiation (parabolic mirrors) with a frame time of 10 seconds and a detector distance of $5.0 \mathrm{~cm}$. A strategy program was used to assure complete coverage of all unique data to a resolution of $0.82 \AA$. All major sections of frames were collected with $1.20^{\circ}$ steps in $\omega$ or $\phi$ at different detector positions in $2 \theta$. The intensity data were corrected for absorption and decay (SADABS). ${ }^{23}$ Final cell constants were calculated from 9246 strong reflections from the actual data collection after integration (SAINT). ${ }^{24}$ Please refer to Table S4 for additional crystal and refinement information.

\section{Structure solution and refinement}

The structure was solved using SHELXT 2014/5 (Sheldrick, 2014) ${ }^{25}$ and refined using SHELXL-2018/3 (Sheldrick, 2018). ${ }^{25}$ The space group $P 2 / n$ was determined based on systematic absences and intensity statistics. A direct-methods solution was calculated which provided most non-hydrogen atoms from the E-map. Full-matrix least squares / difference Fourier cycles were performed which located the remaining non-hydrogen atoms. All non-hydrogen atoms were refined with anisotropic displacement parameters. All hydrogen atoms were placed in ideal positions and refined as riding atoms with relative isotropic displacement parameters. The final full matrix least squares refinement converged to $R 1=0.1018$ and $w R 2=0.2920\left(F^{2}\right.$, obs. data).

\section{Structure description}

The structure is the one suggested as a solvate of both toluene and DCM. The toluene occupies a single position. The DCM is disordered with the para-trifluorotoluyl group at C11. The DCM resides on either side of the molecule pushing para-trifluorotoluyl group away in a 0.78:0.22 ratio. The anthracenone group at C6 responds by having two positions itself. There are many atoms involved in this disorder. The $\mathrm{R} 1$ is about $10 \%$, but this result is acceptable for publication given its limitations for accuracy are presented.

Data collection and structure solution were conducted at the X-Ray Crystallographic Laboratory, 192 Kolthoff Hall, Department of Chemistry, University of Minnesota. All calculations were performed using Pentium computers using the current SHELXTL suite of programs.
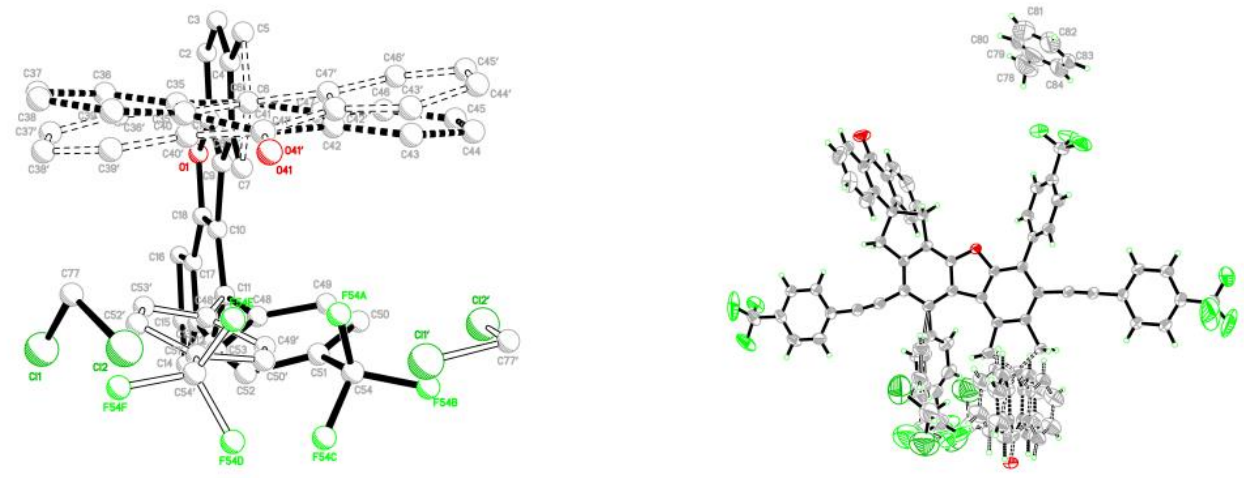
Table S4. Crystal data and structure refinement for $20108 z z$ (17-U)

Identification code

Empirical formula

Formula weight

Temperature

Wavelength

Crystal system

Space group

Unit cell dimensions

Volume

Z

Density (calculated)

Absorption coefficient

$F(000)$

Crystal color, morphology

Crystal size

Theta range for data collection

Index ranges

Reflections collected

Independent reflections

Observed reflections

Completeness to theta $=25.242^{\circ}$

Absorption correction

Max. and min. transmission

Refinement method

Data / restraints / parameters

Goodness-of-fit on $F^{2}$

Final $R$ indices $[I>2 \operatorname{sigma}(I)]$

$R$ indices (all data)

Largest diff. peak and hole 20108zz

$\mathrm{C}_{84} \mathrm{H}_{50} \mathrm{Cl}_{2} \mathrm{~F}_{2} \mathrm{O}_{3}$

1406.14

125(2) K

$0.71073 \AA$

Monoclinic

P 2/n

$a=25.966(3) \AA$

$\alpha=90^{\circ}$

$b=8.9107(8) \AA$

$\beta=107.284(3)^{\circ}$

$c=29.860(3) \AA$

$\gamma=90^{\circ}$

4

$1.416 \mathrm{Mg} / \mathrm{m}^{3}$

$0.186 \mathrm{~mm}^{-1}$

2880

yellow, block

$0.200 \times 0.200 \times 0.150 \mathrm{~mm}^{3}$

2.286 to $25.681^{\circ}$

$-31 \leq h \leq 31,-10 \leq k \leq 10,-36 \leq l \leq 36$

120198

$12518[R($ int $)=0.0476]$

10140

$99.9 \%$

Multi-scan

0.7457 and 0.6645

Full-matrix least-squares on $F^{2}$

12518 / 148 / 1053

1.087

$R 1=0.1018, w R 2=0.2920$

$R 1=0.1189, w R 2=0.3114$

1.298 and -1.292 e. $\AA^{-3}$ 


\section{Supporting information references} Angew. Chem. Int. Ed. 2016, 55, 1797-1800.$$
\text { 9624-9628. }
$$

13 Hoye, T. R.; Baire, B.; Niu, D.; Willoughby, P. H.; Woods, B. P. Nature 2012, 490, 208-211.

14 Frisch, M. J.; Trucks, G. W.; Schlegel, H. B.; Scuseria, G. E.; Robb, M. A.; Cheeseman, J. R.; Scalmani, G.; Barone, V.; Petersson, G. A.; Nakatsuji, H.; Li, X.; Caricato, M.; Marenich, A. V.; Bloino, J.; Janesko, B. G.; Gomperts, R.; Mennucci, B.; Hratchian, H. P.; Ortiz, J. V.; Izmaylov, A. F.; Sonnenberg, J. L.; Williams-Young, D.; Ding, F.; Lipparini, F.; Egidi, F.; Goings, J.; Peng, B.; Petrone, A.; Henderson, T.; Ranasinghe, D.; Zakrzewski, V. G.; Gao, J.; Rega, N.; Zheng, G.; Liang, W.; Hada, M.; Ehara, M.; Toyota, K.; Fukuda, R.; Hasegawa, J.; Ishida, M.; Nakajima, T.; Honda, Y.; Kitao, O.; Nakai, H.; Vreven, T.; Throssell, K.; Montgomery, J. A., Jr.; Peralta, J. E.; Ogliaro, F.; Bearpark, M. J.; Heyd, J. J.; Brothers, E. N.; Kudin, K. N.; Staroverov, V. N.; Keith, T. A.; Kobayashi, R.; Normand, J.; Raghavachari, K.; Rendell, A. P.; Burant, J. C.; lyengar, S. S.; Tomasi, J.; Cossi, M.; Millam, J. M.; Klene, M.; Adamo, C.; Cammi, R.; Ochterski, J. W.; Martin, R. L.; Morokuma, K.; Farkas, O.; Foresman, J. B.; Fox, D. J. Gaussian 16, Revision C.01, Gaussian, Inc., Wallingford CT, 2016.

15 Zhao, Y.; Truhlar, D. G. Theoretical Chemistry Accounts 2008, 120, 215-241.

16 Marenich, A. V.; Cramer, C. J.; Truhlar, D. G. J. Phys. Chem. B 2009, 113, 6378-6396. Science 2018, 362, 799-804.

21

(a) Shi, J.; Li, L.; Li, Y. Chem. Rev. 2021 121, 3892-4044. Y.; Luo, F.; Peng, B. Org. Lett. 2019, 21, 3986-3989.

22 APEX3, Bruker Analytical X-ray Systems, Madison, WI (2014).

23 SADABS, Bruker Analytical X-ray Systems, Madison, WI (2014).

24 SAINT Bruker Analytical X-ray Systems, Madison, WI (2014).

SHELXTL 2013, Bruker Analytical X-Ray Systems, Madison, WI (2013); G. M. Sheldrick, Acta Cryst. A64, 112-122 (2008).

\section{Copies of NMR spectra}



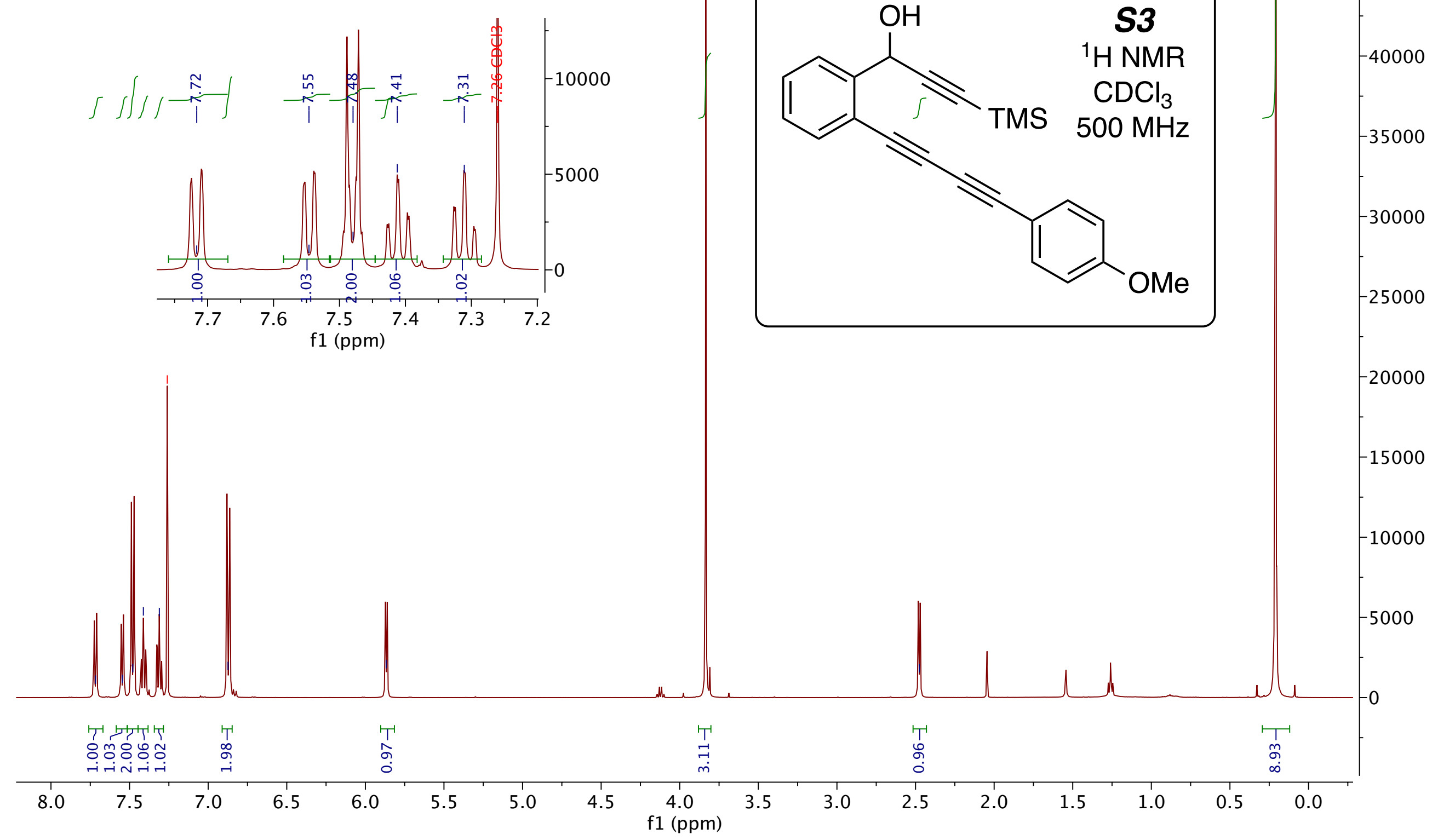

i 
S3/13C

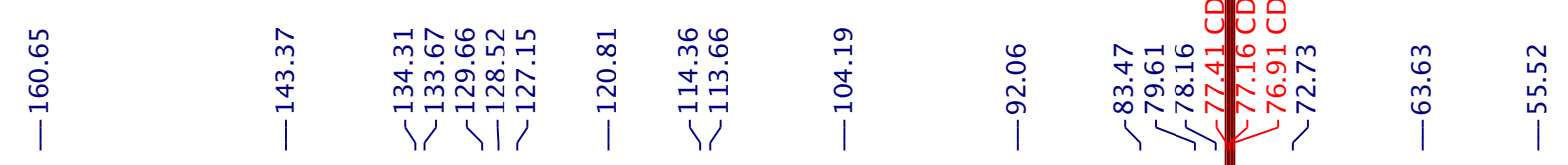

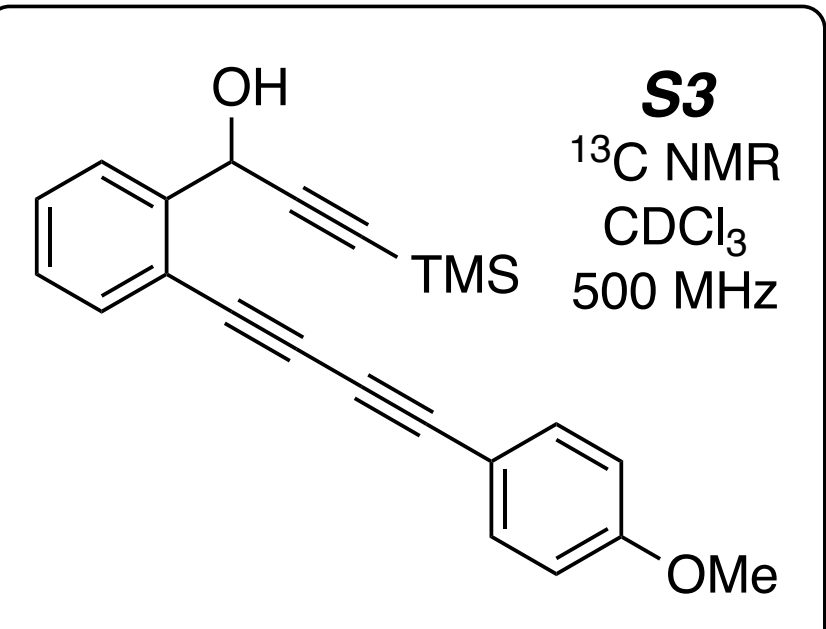

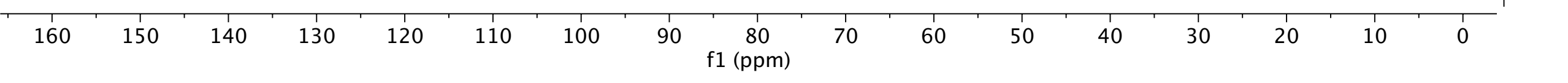



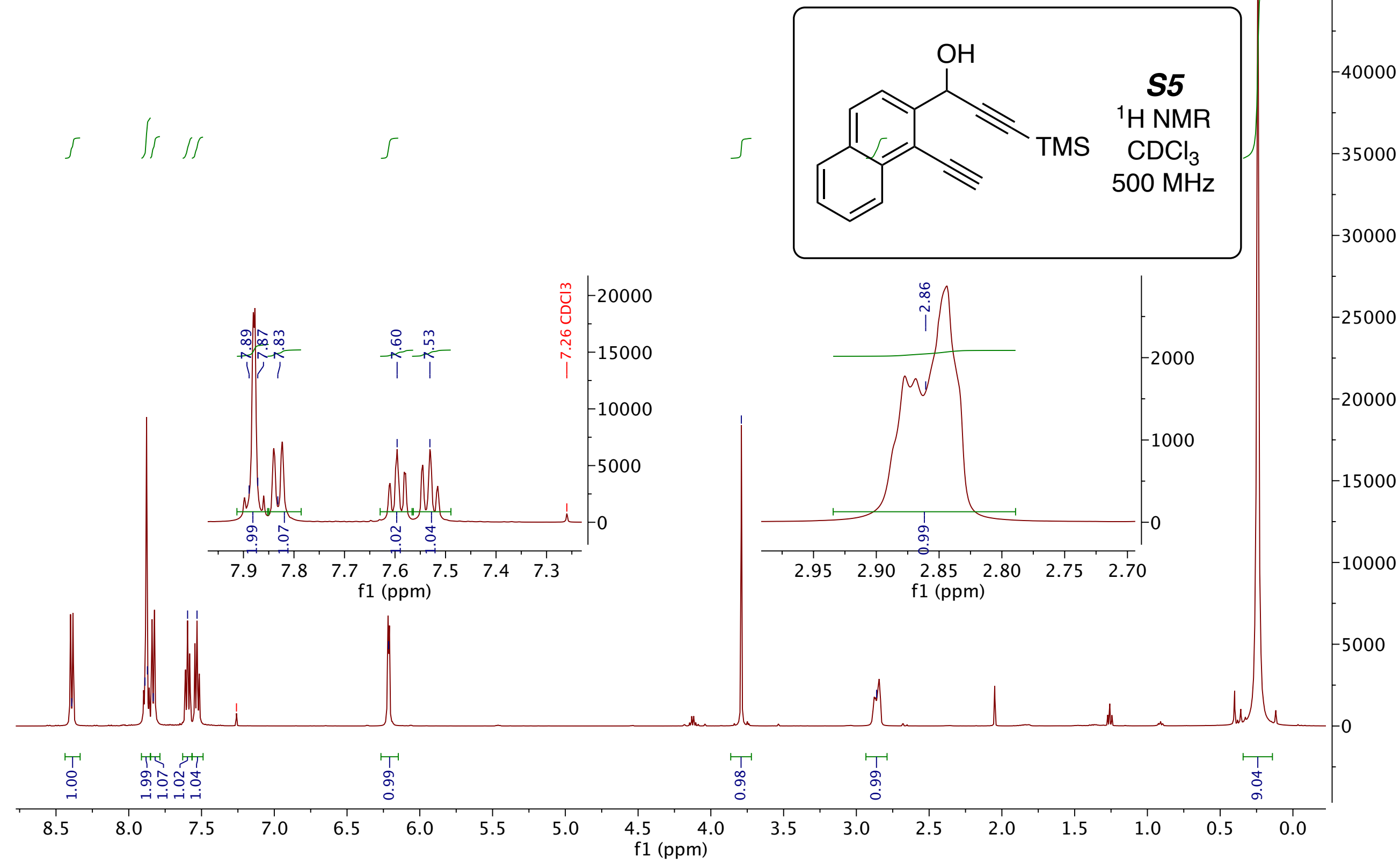


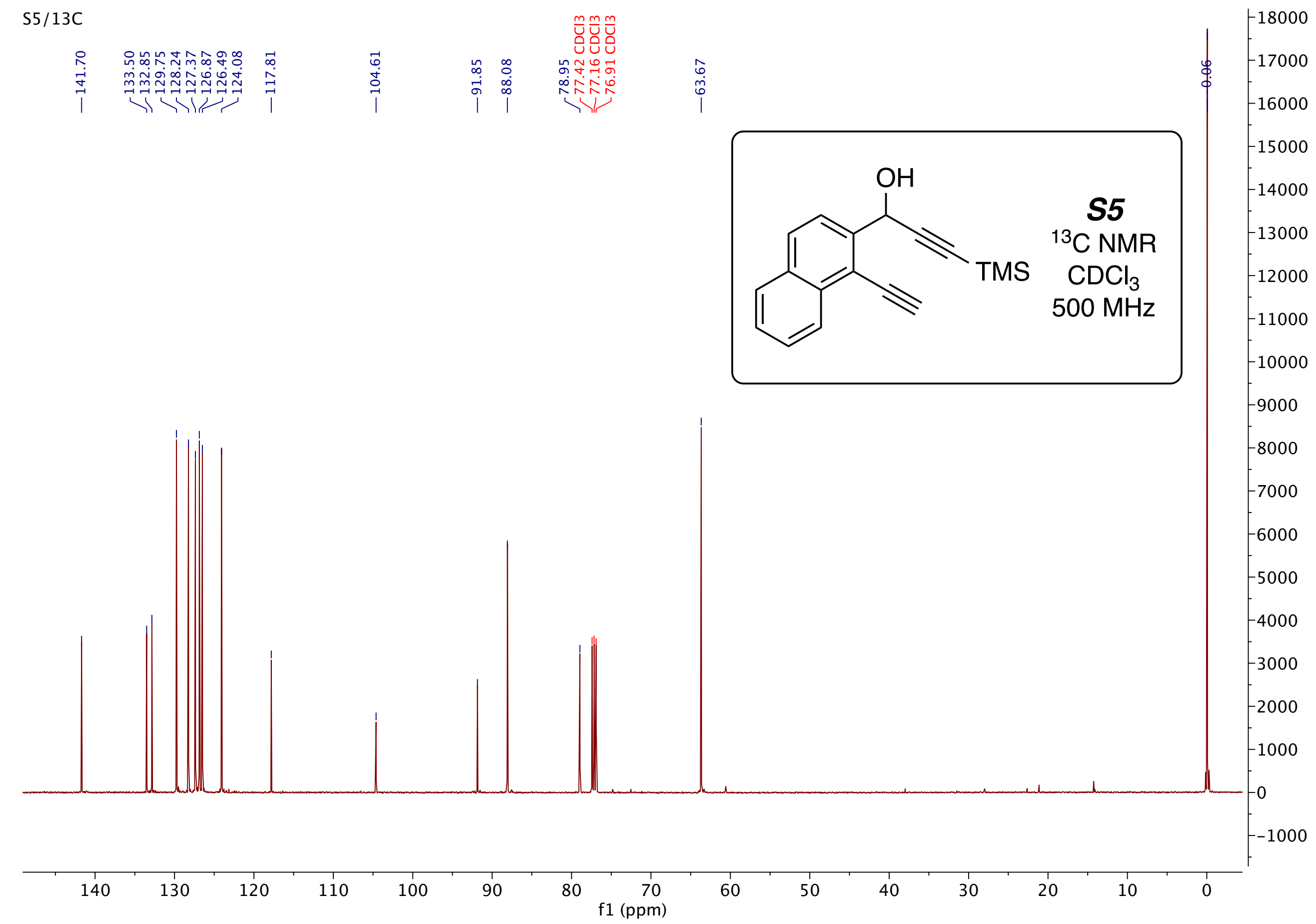



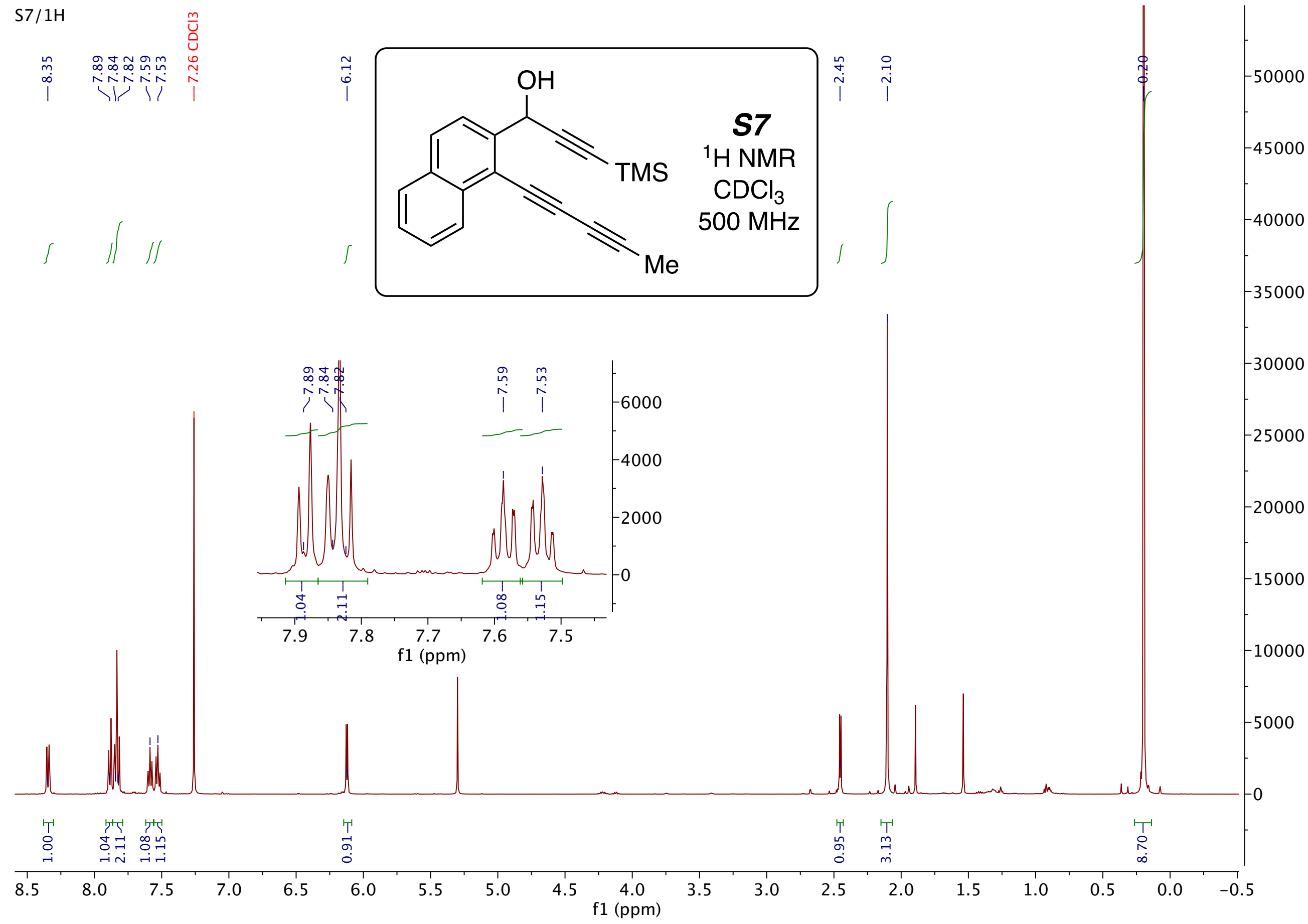

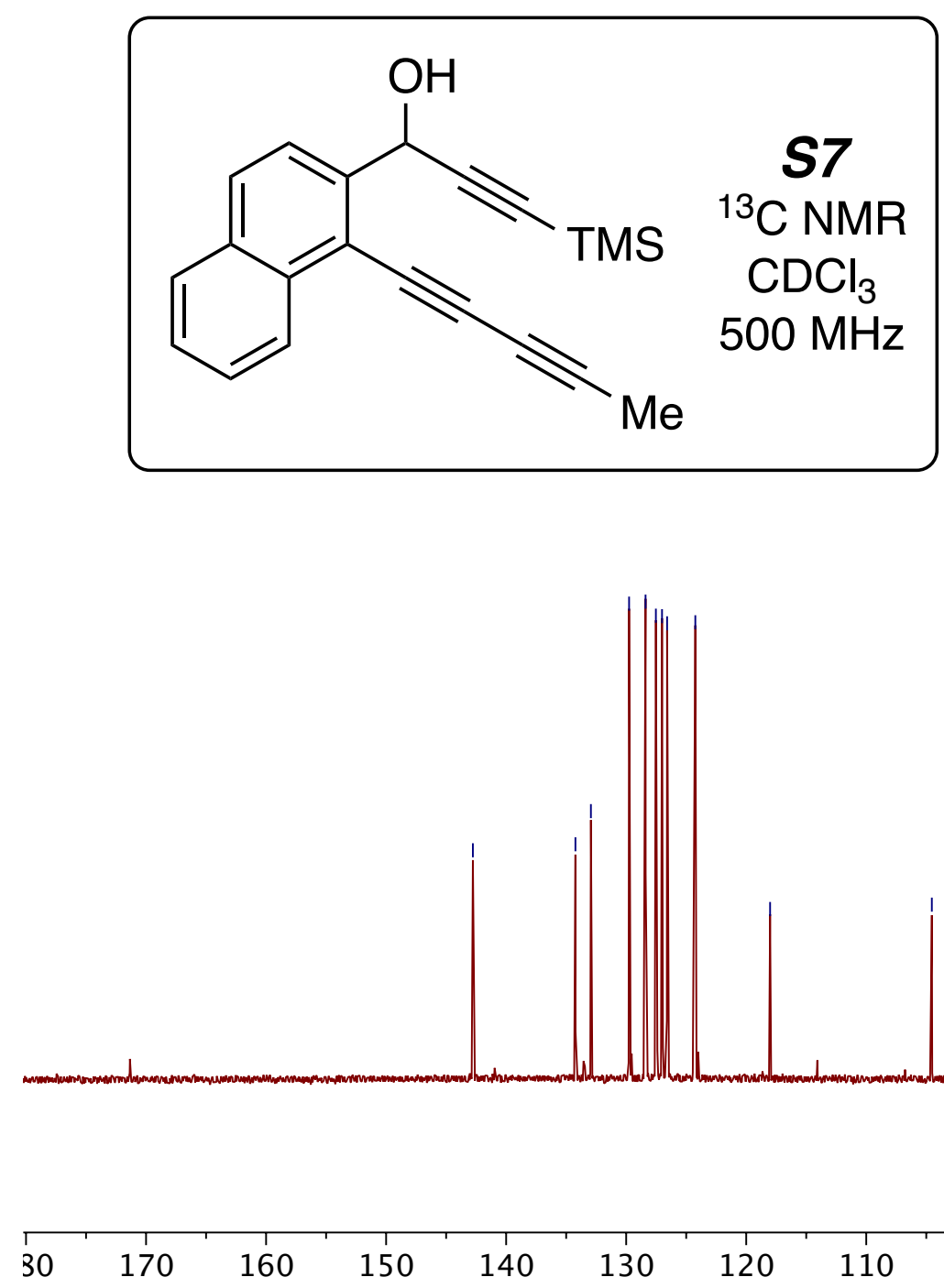

monnom

$\begin{array}{llll}70 & 160 & 150 & 140\end{array}$

130

120

110

100

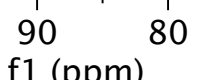

70

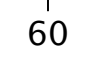

50

40

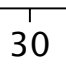




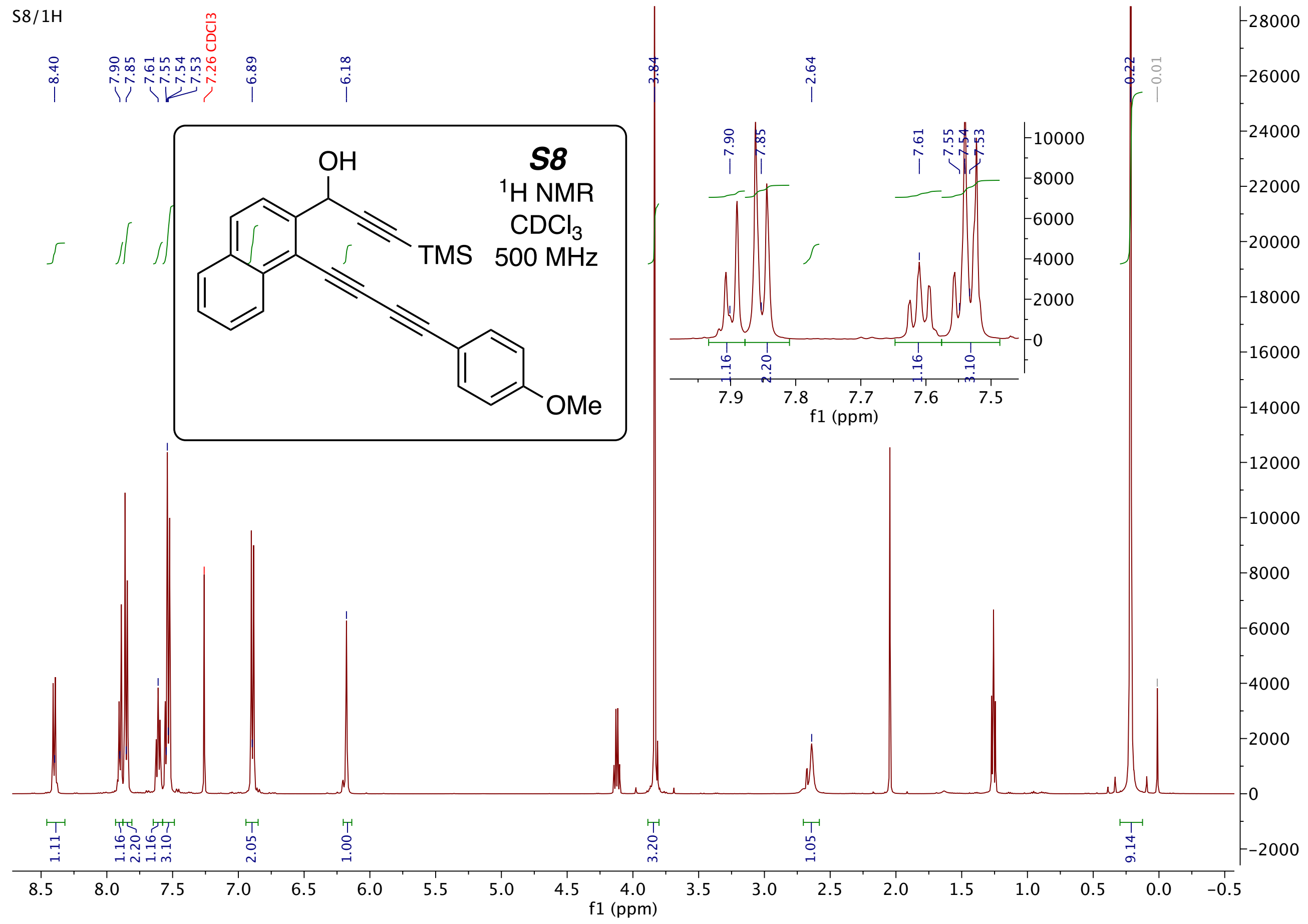




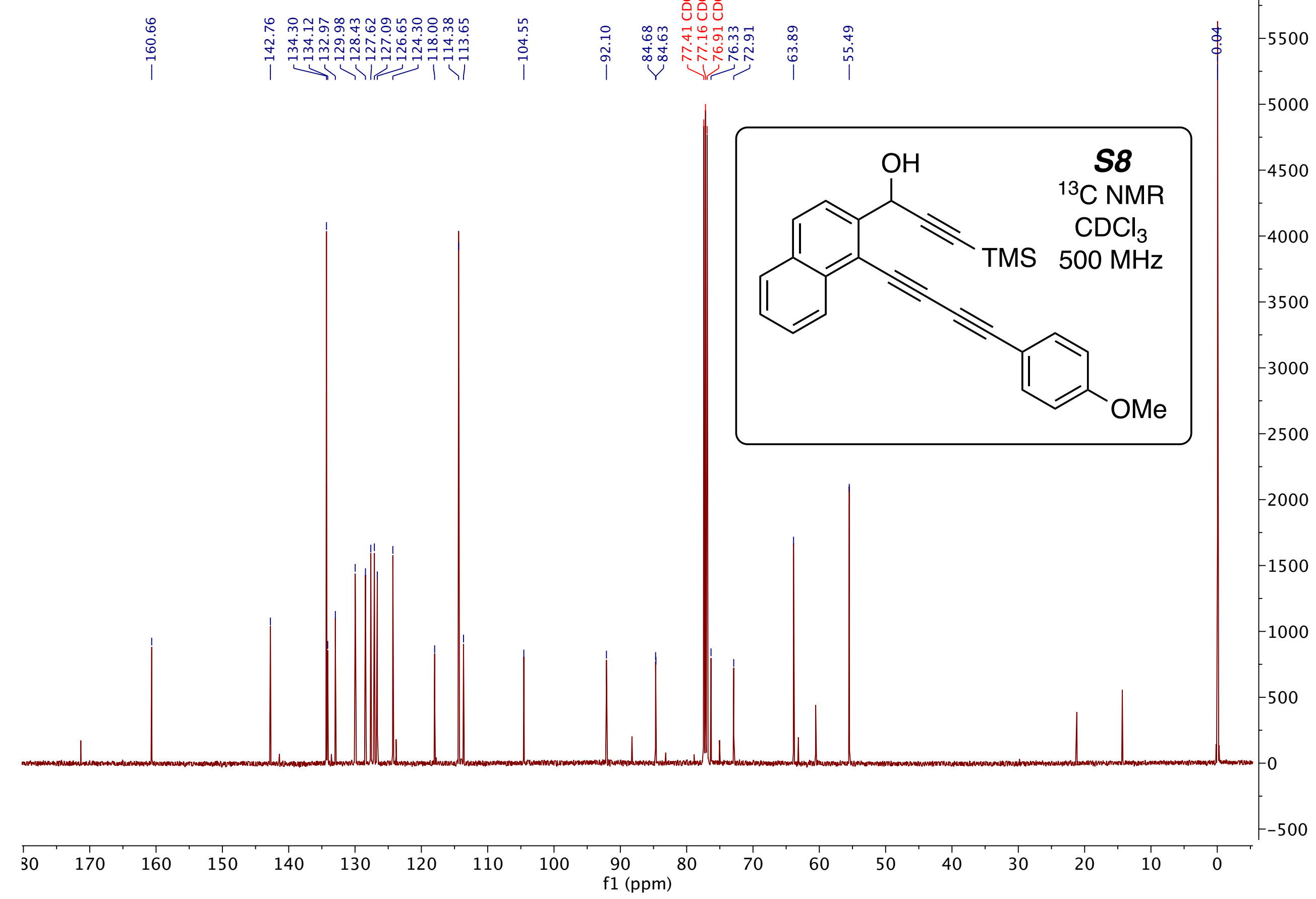




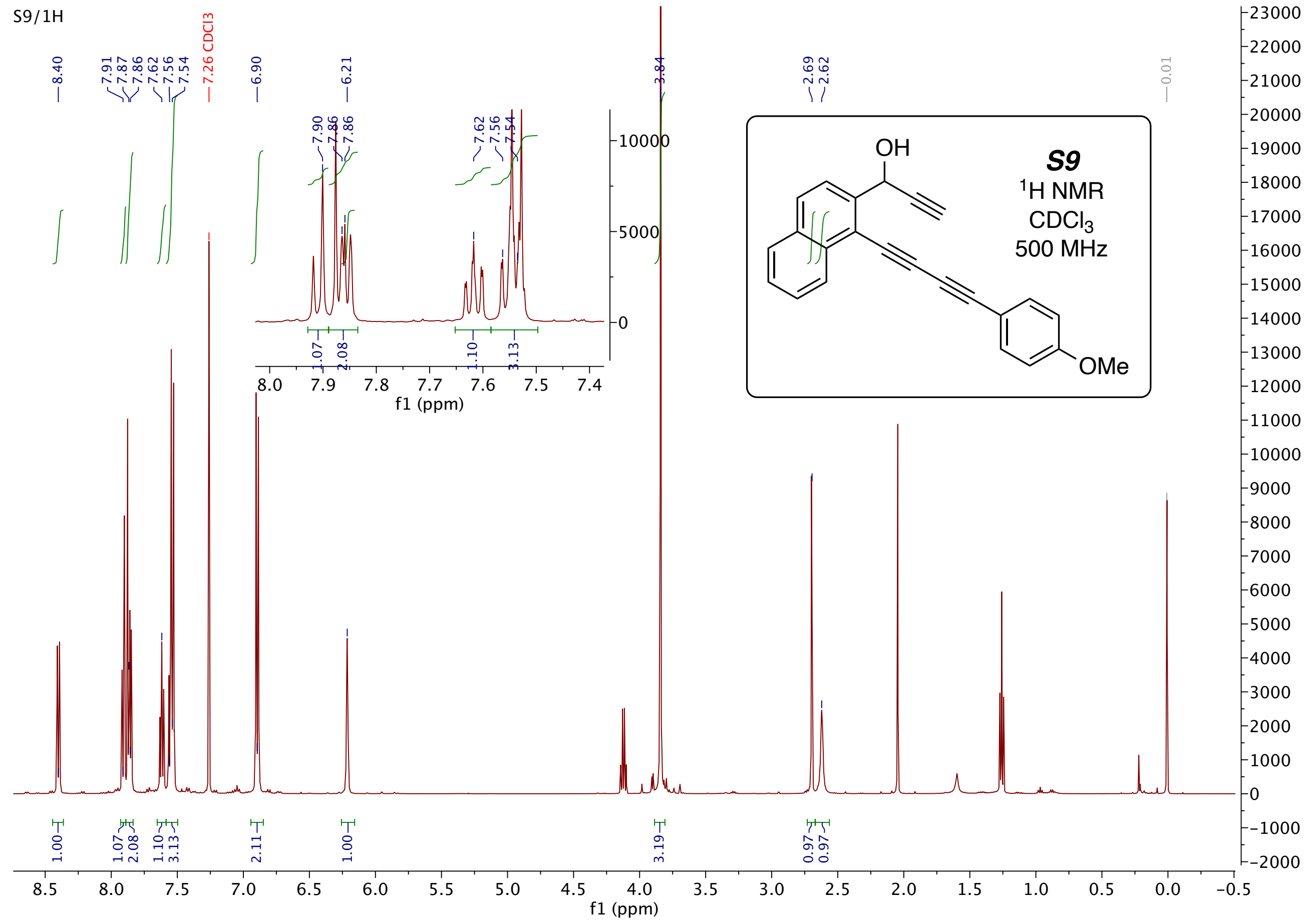



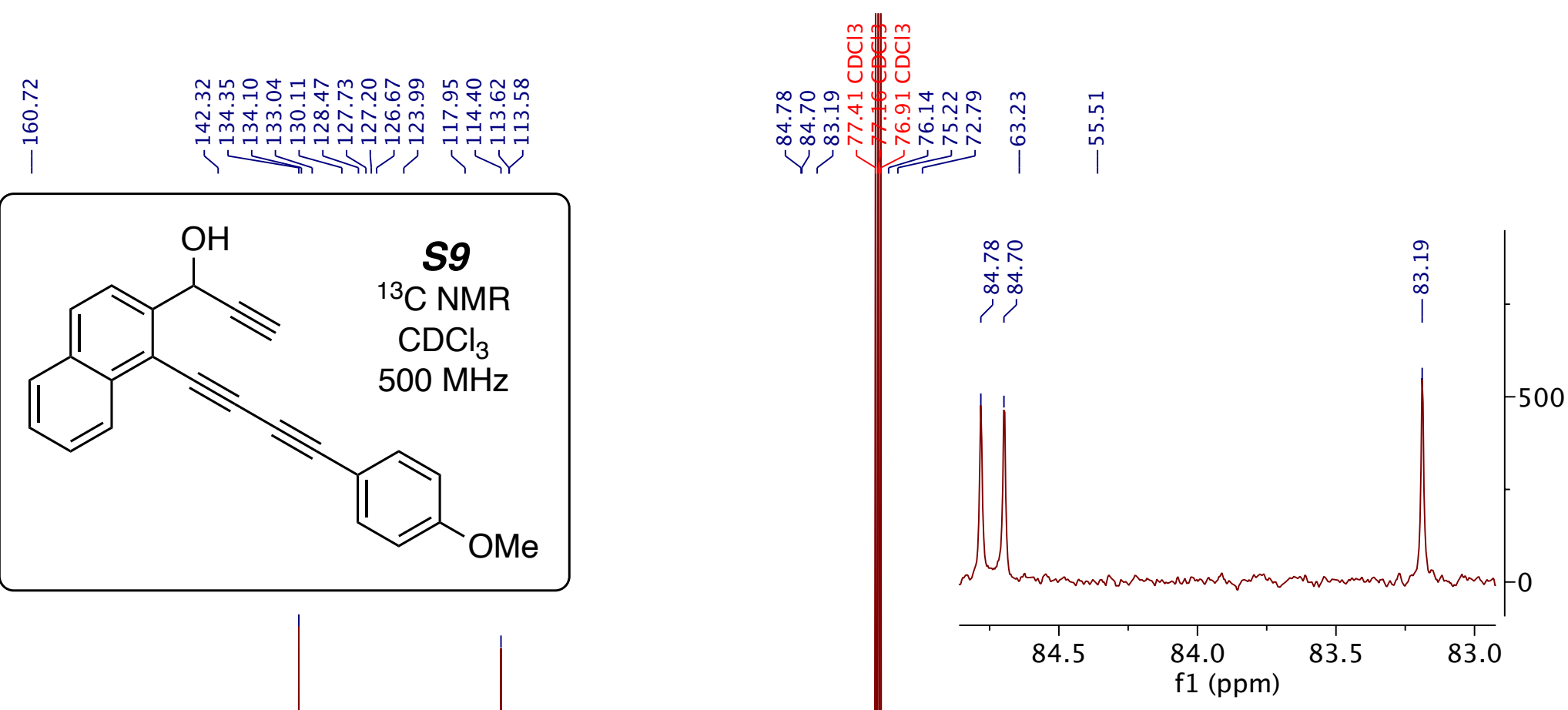


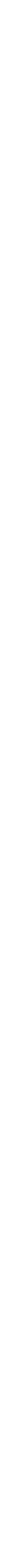



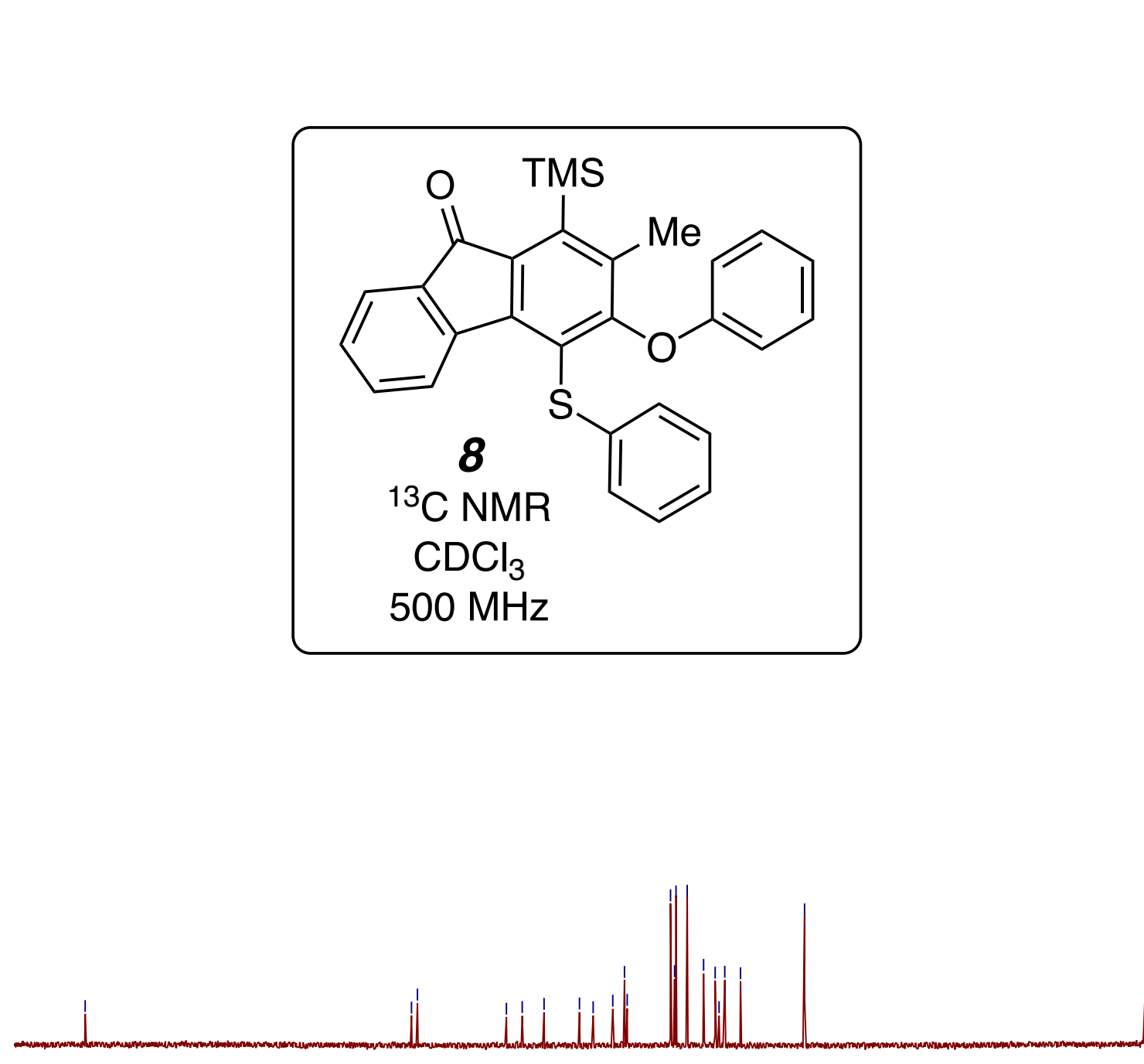


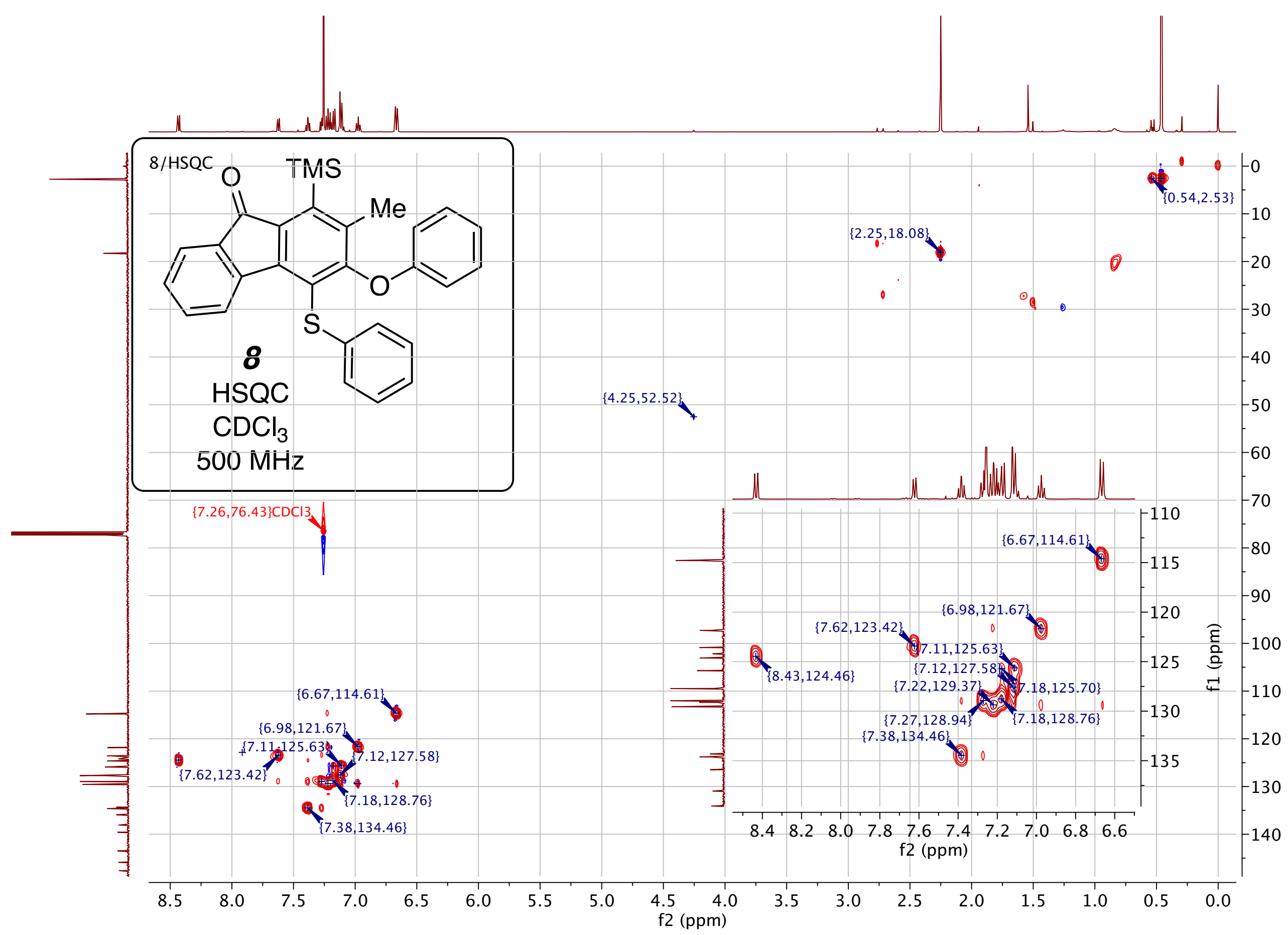




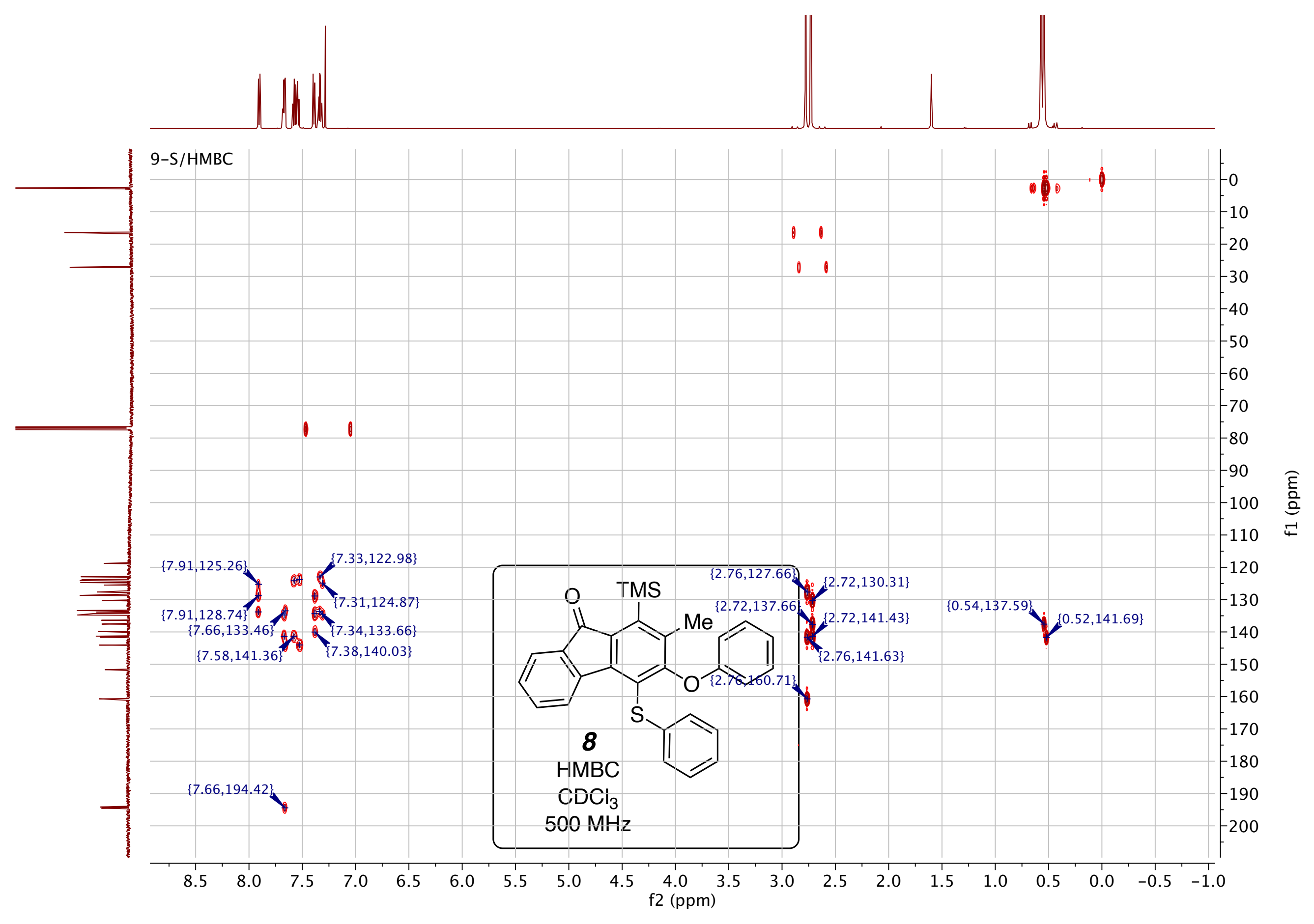




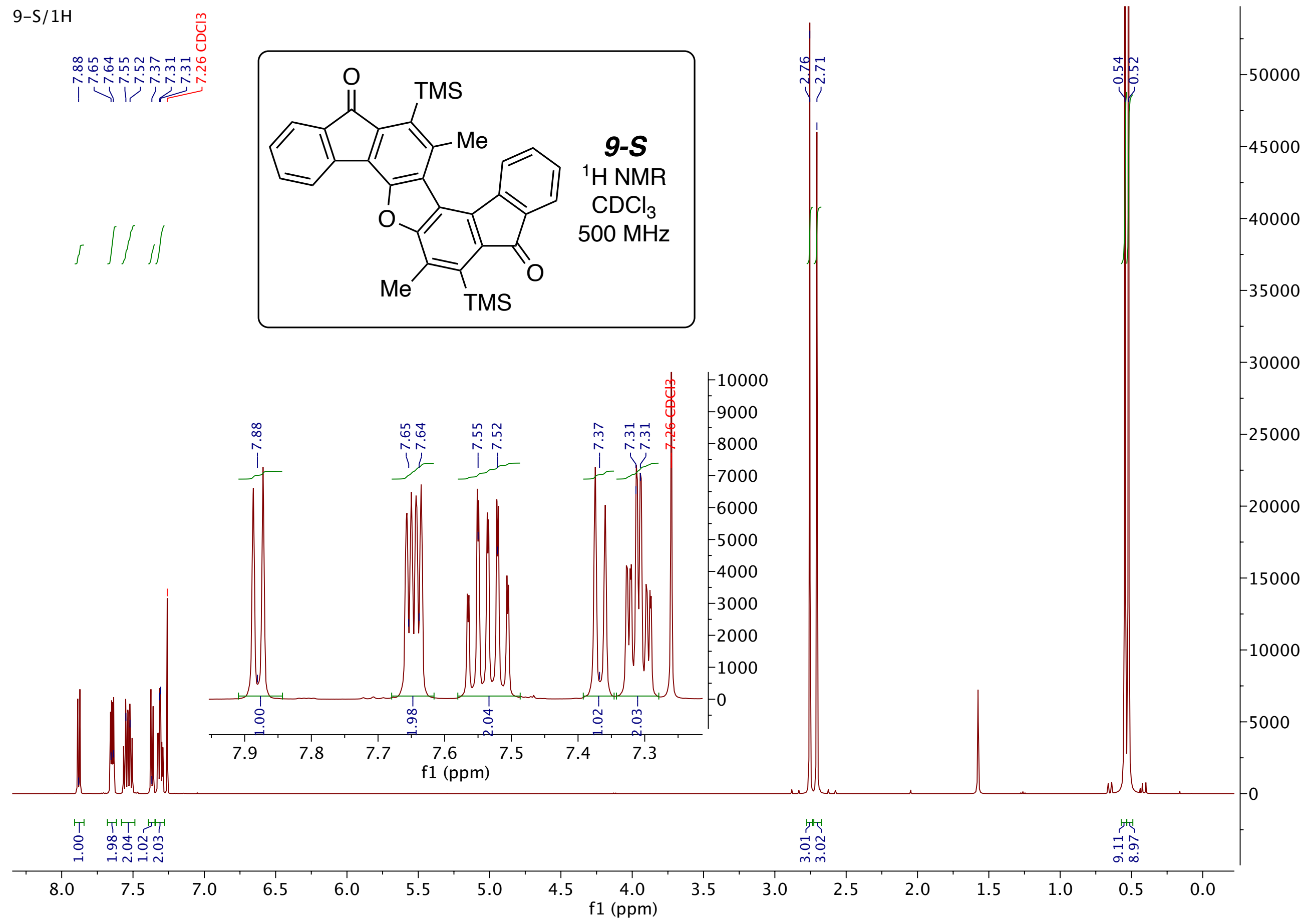


9-S/13C
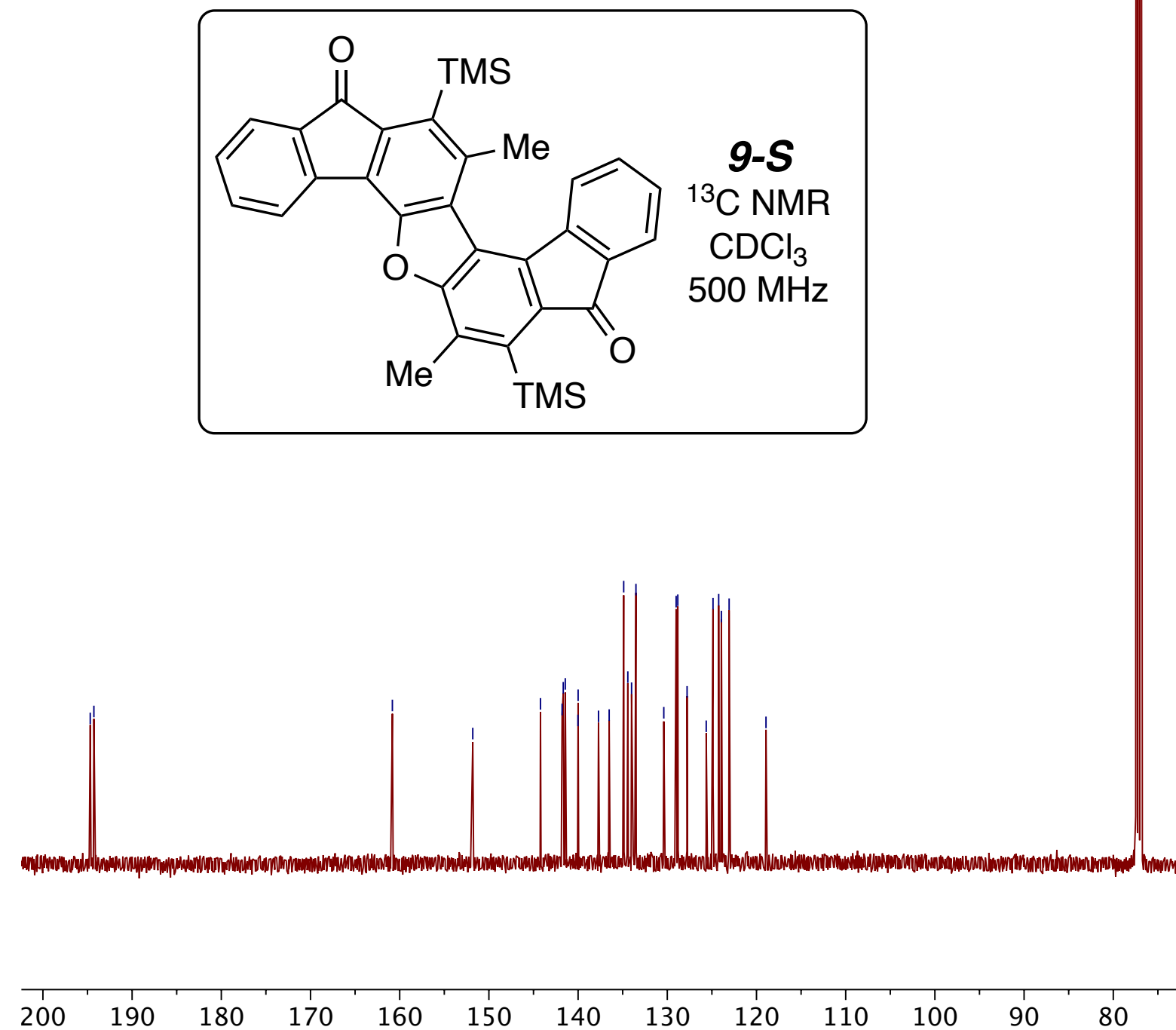

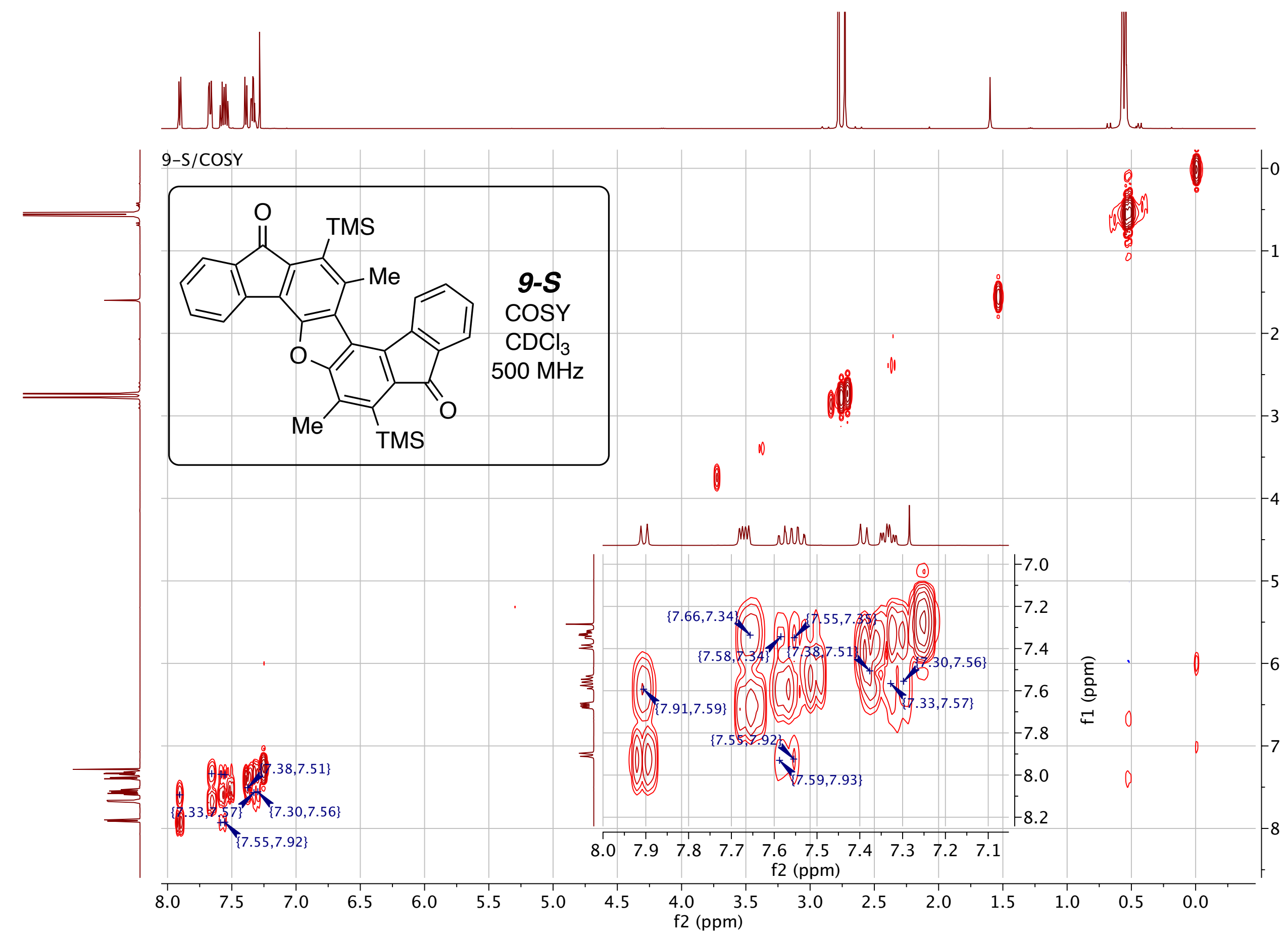

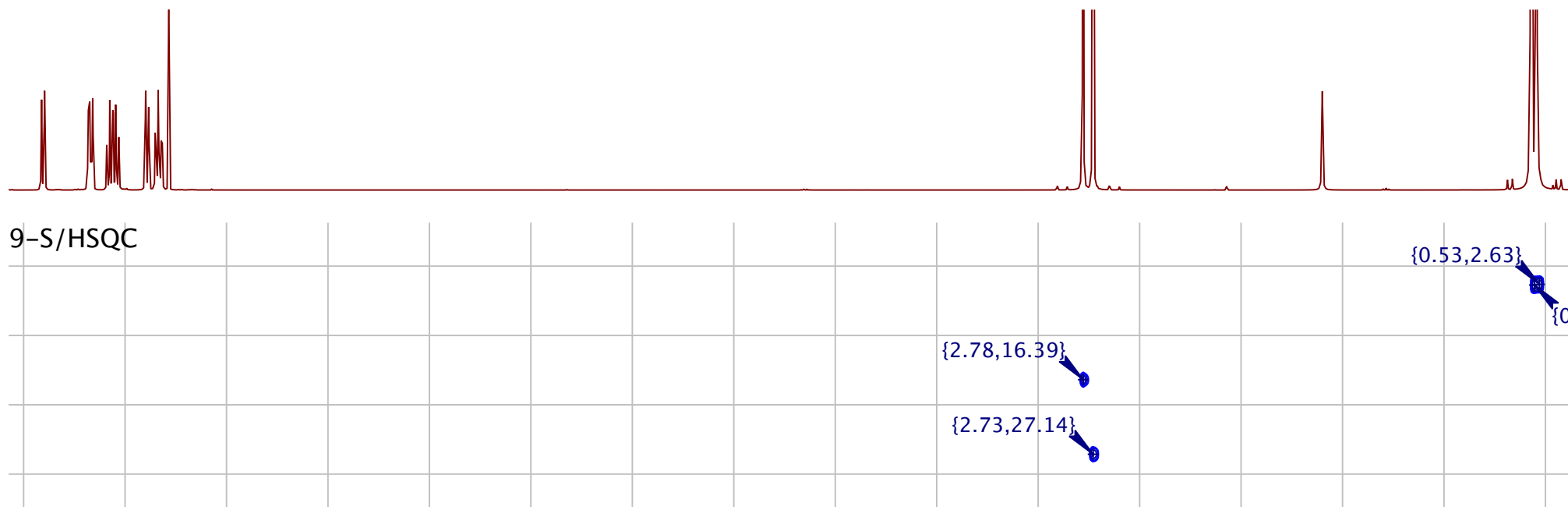

$\{7.92,122.97\}$

1. $\left\{\begin{array}{l}\{7.33,128.87\} \\ \{.39,124.75\}\end{array}\right.$
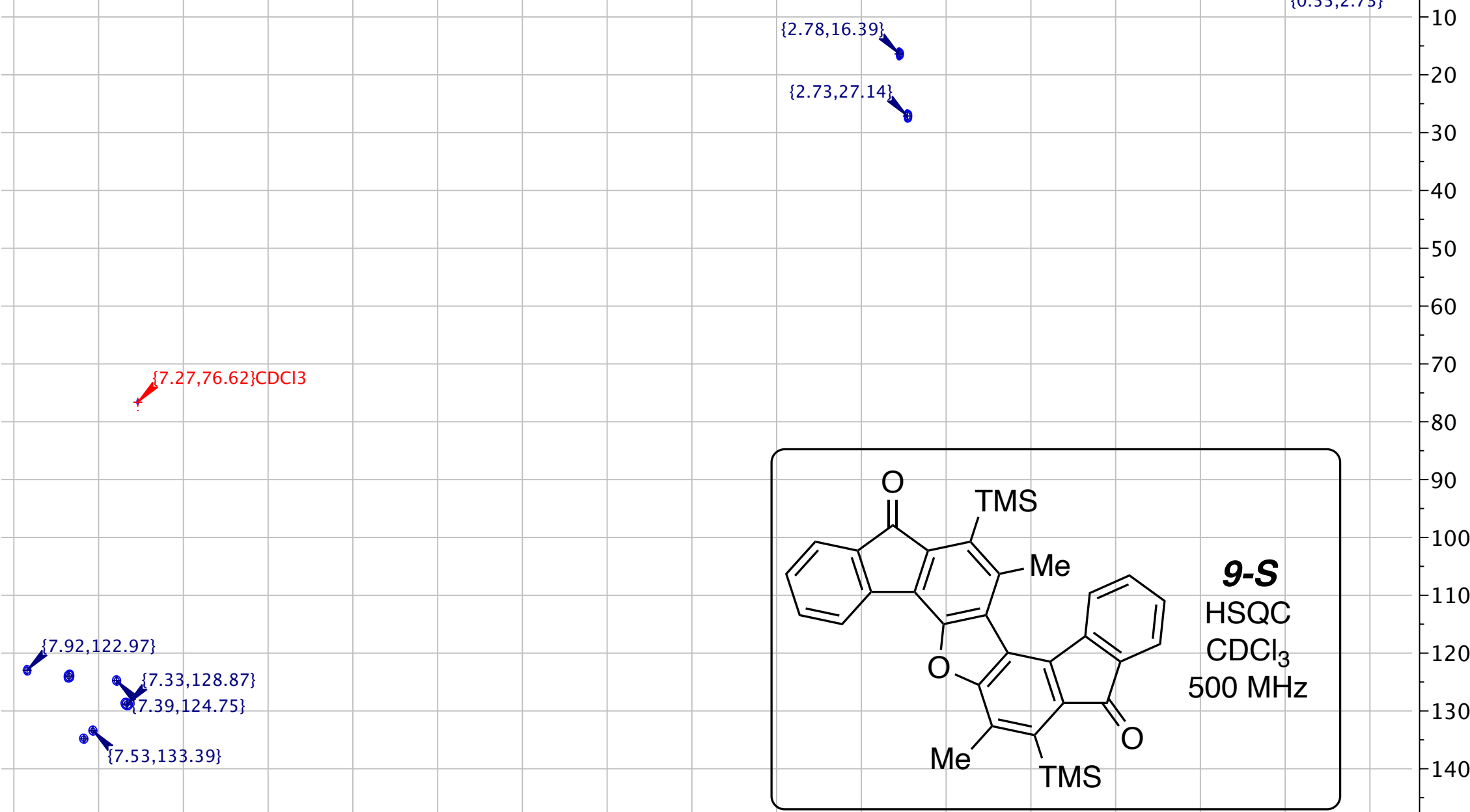


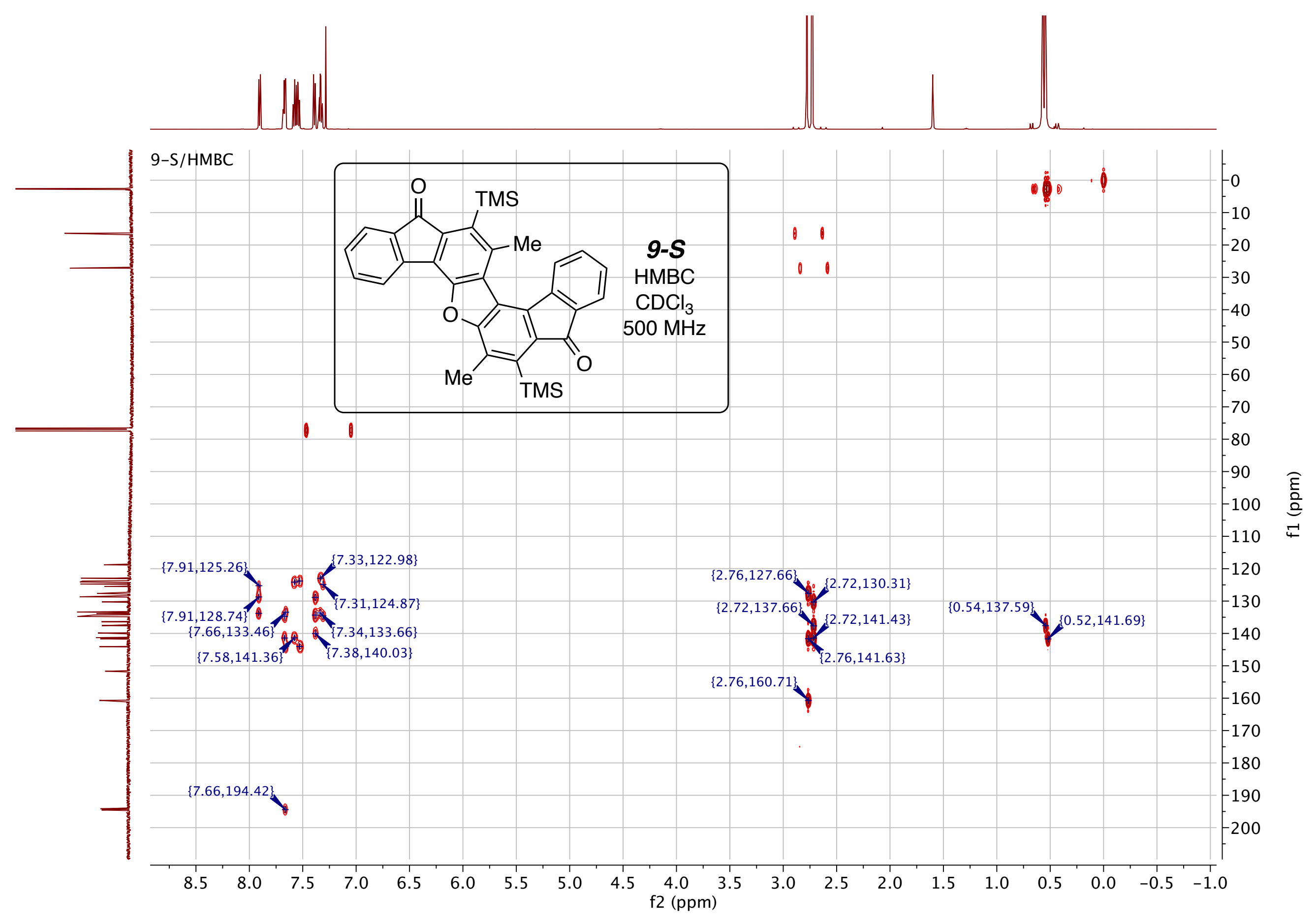




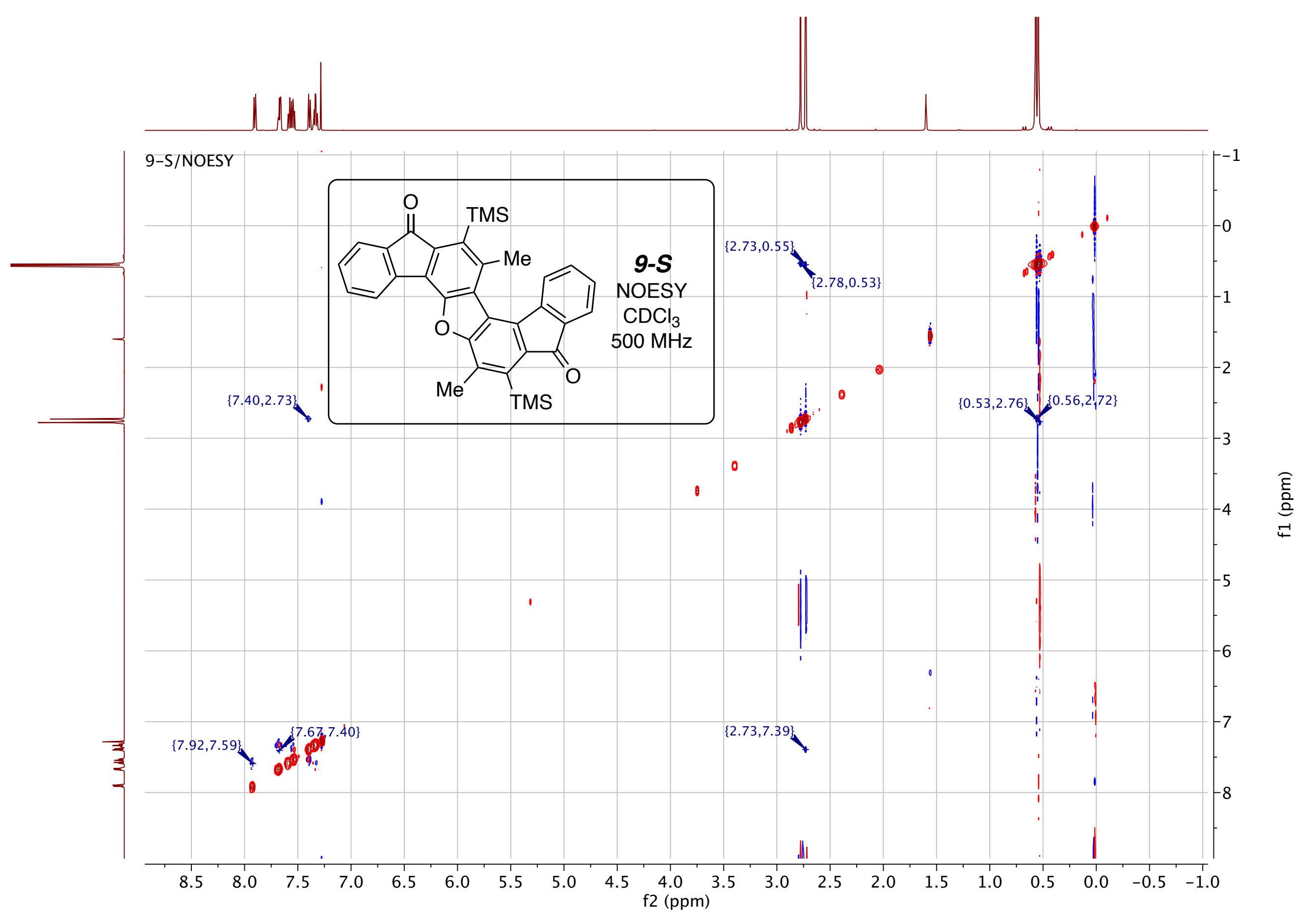




$$
\begin{aligned}
& \text { 부워ำ } \\
& \text { i र्गां। }
\end{aligned}
$$
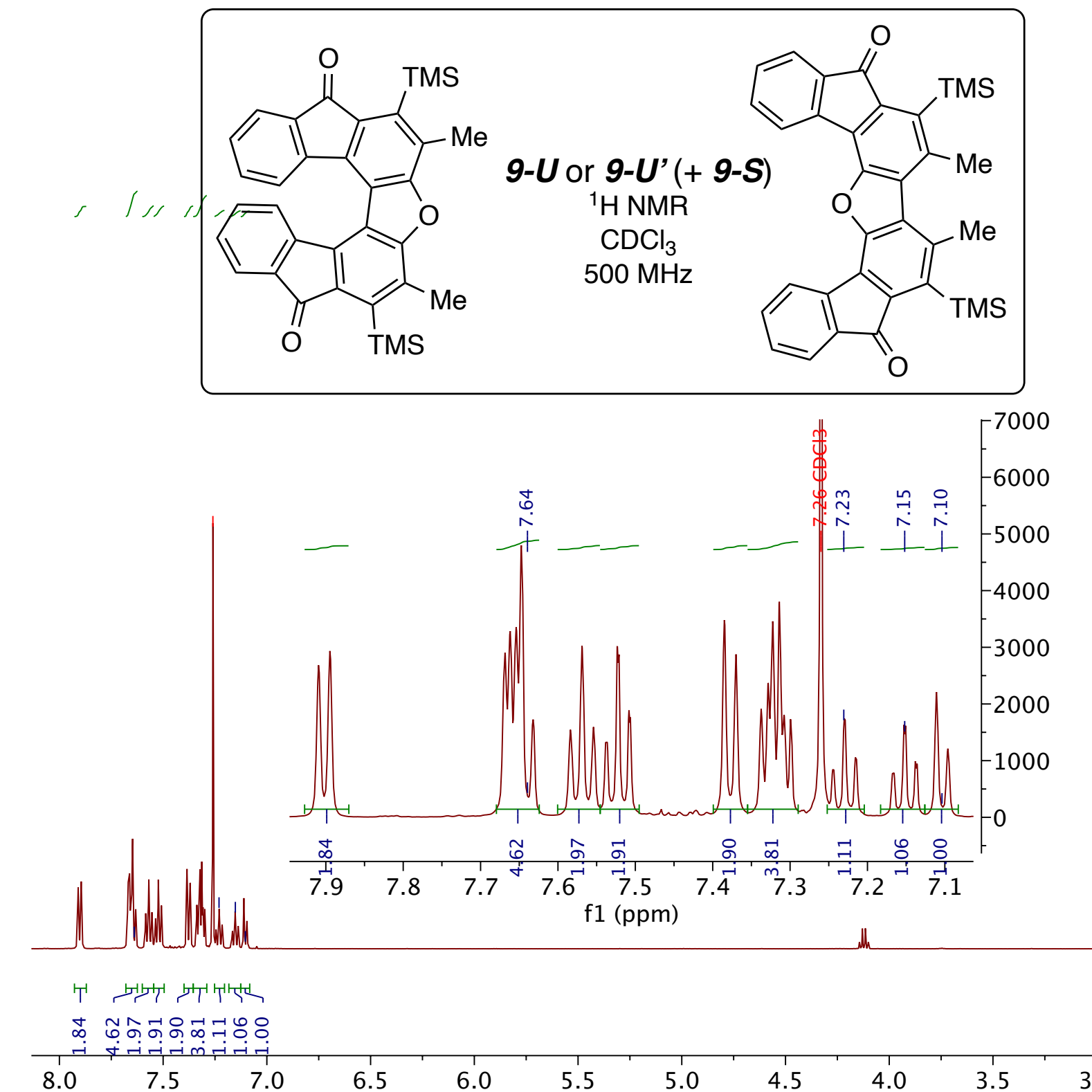

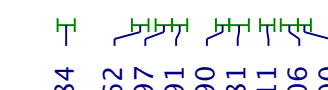

$8.0 \quad 7.5 \quad 7.0$

$6.5 \quad 6.0$

+

$\stackrel{\sim}{i}$
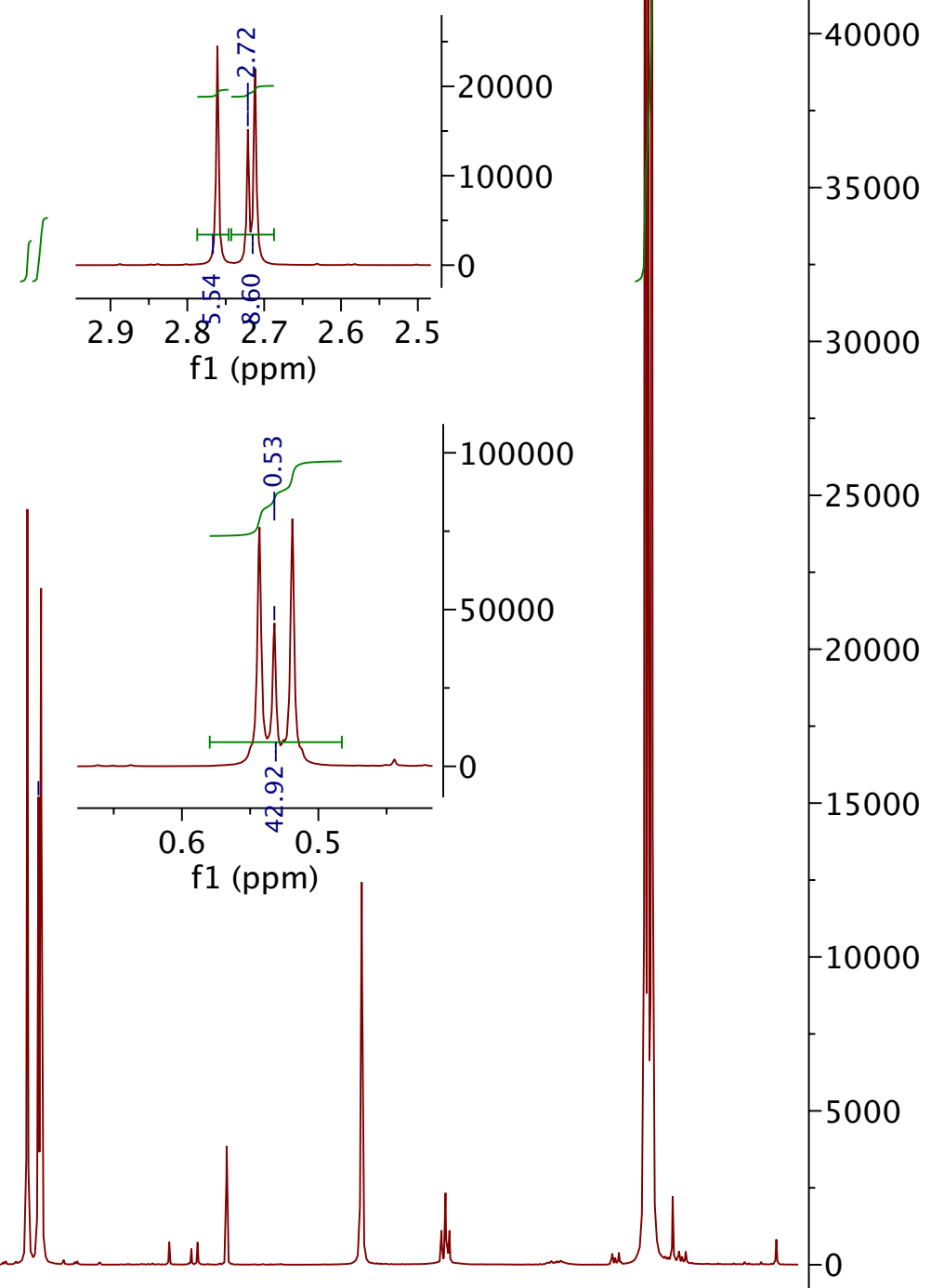

-45000
-40000
-35000
-30000
-25000
-20000
-15000
-10000
-
-
-




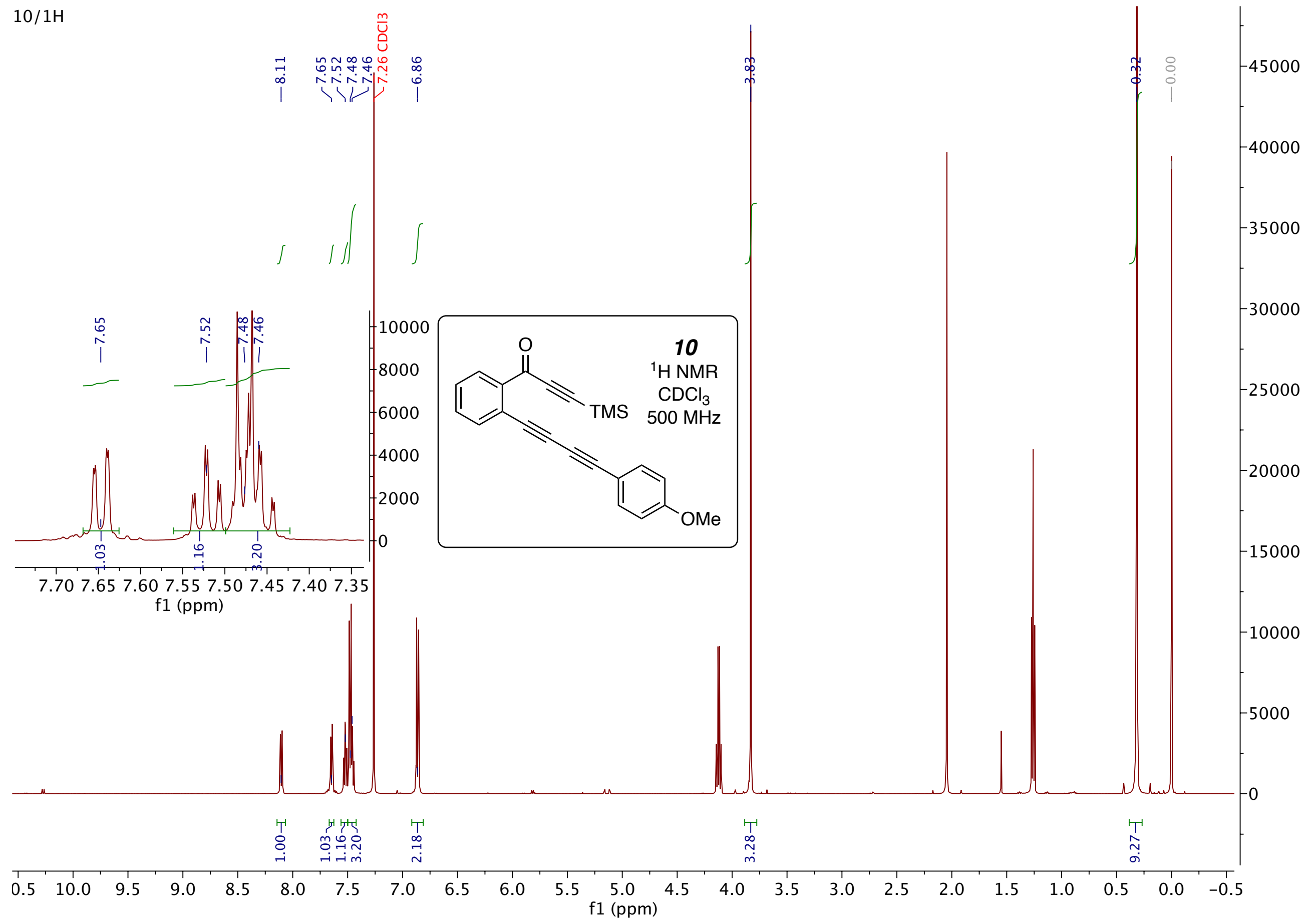




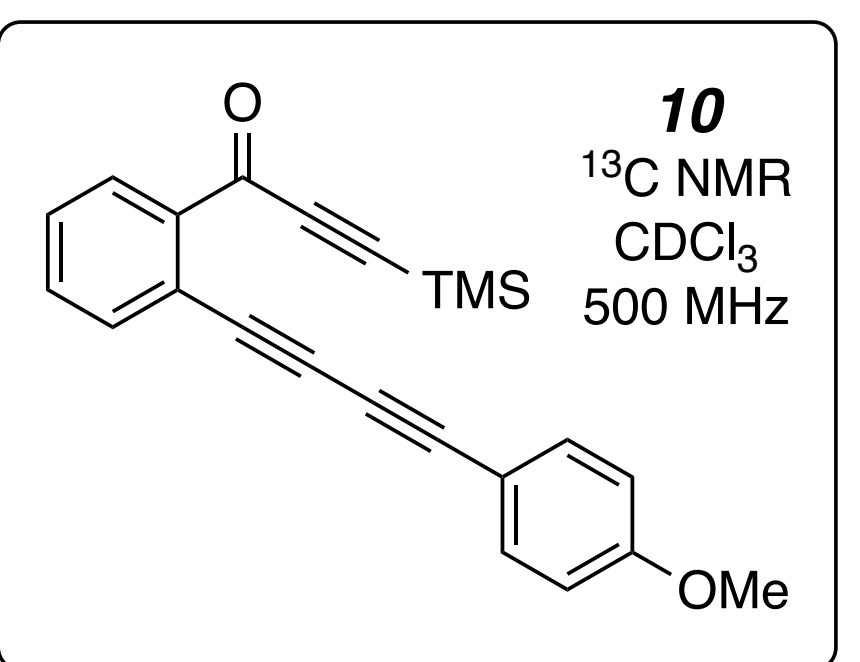




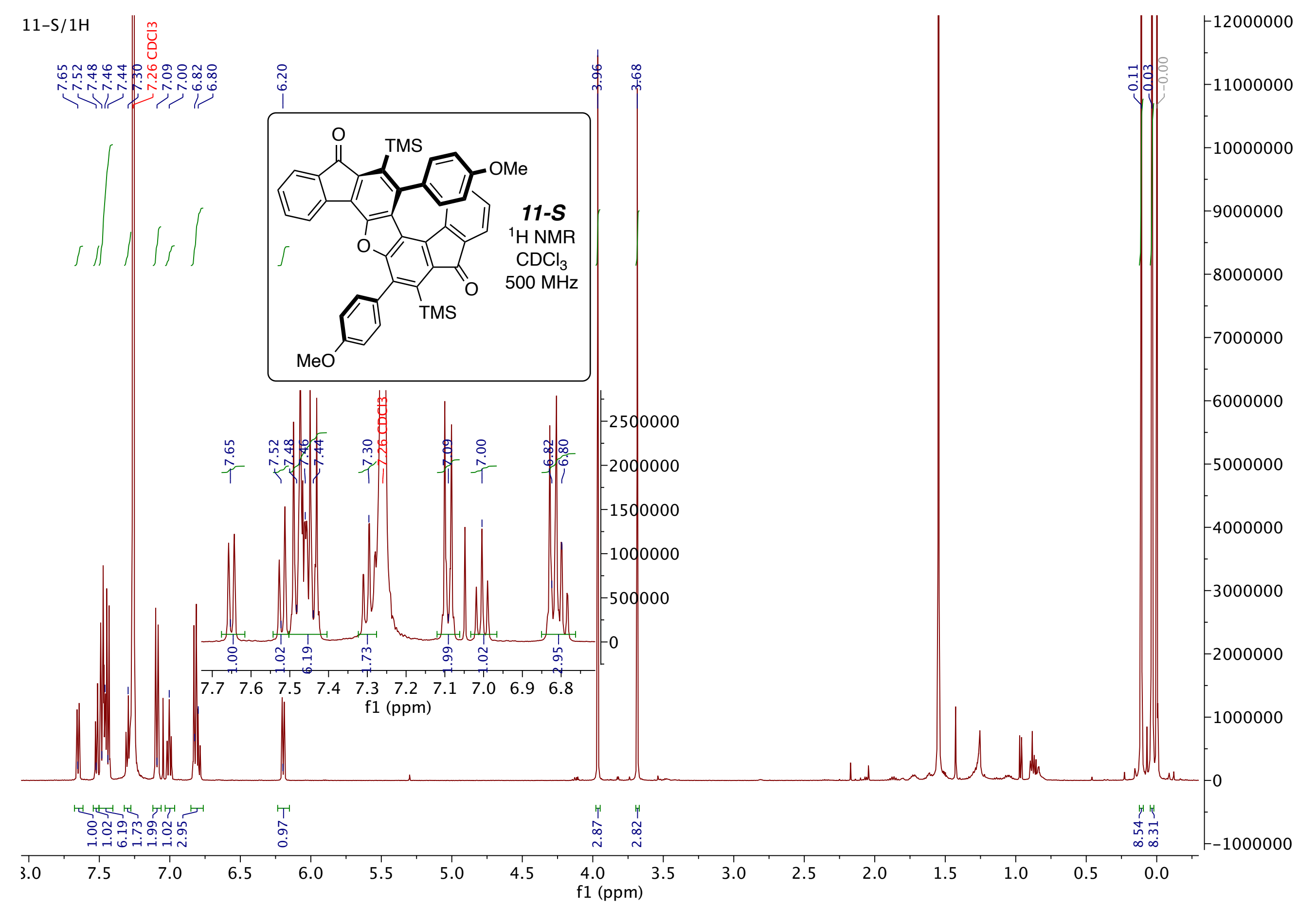




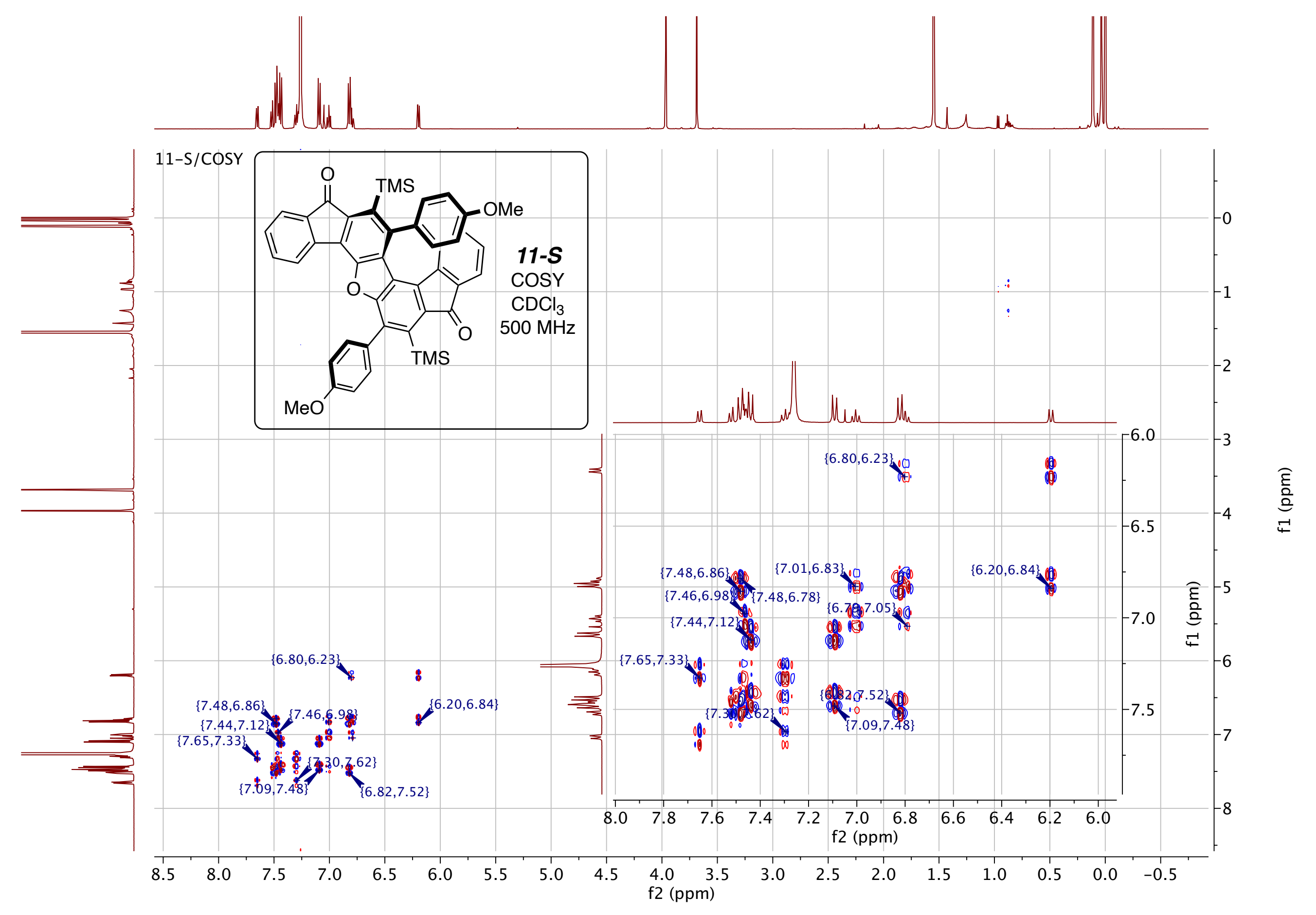




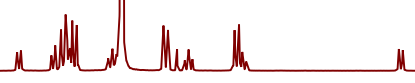
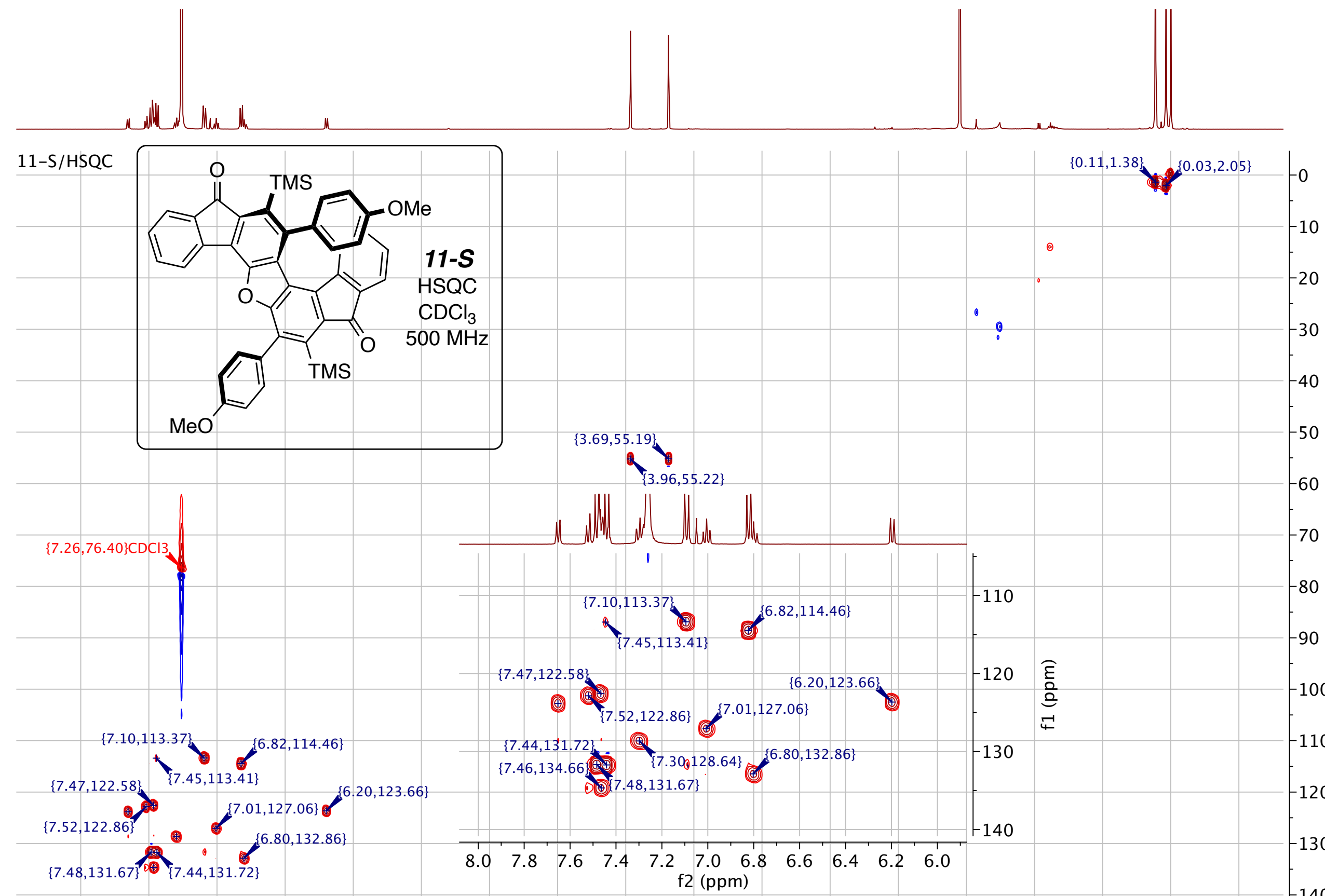


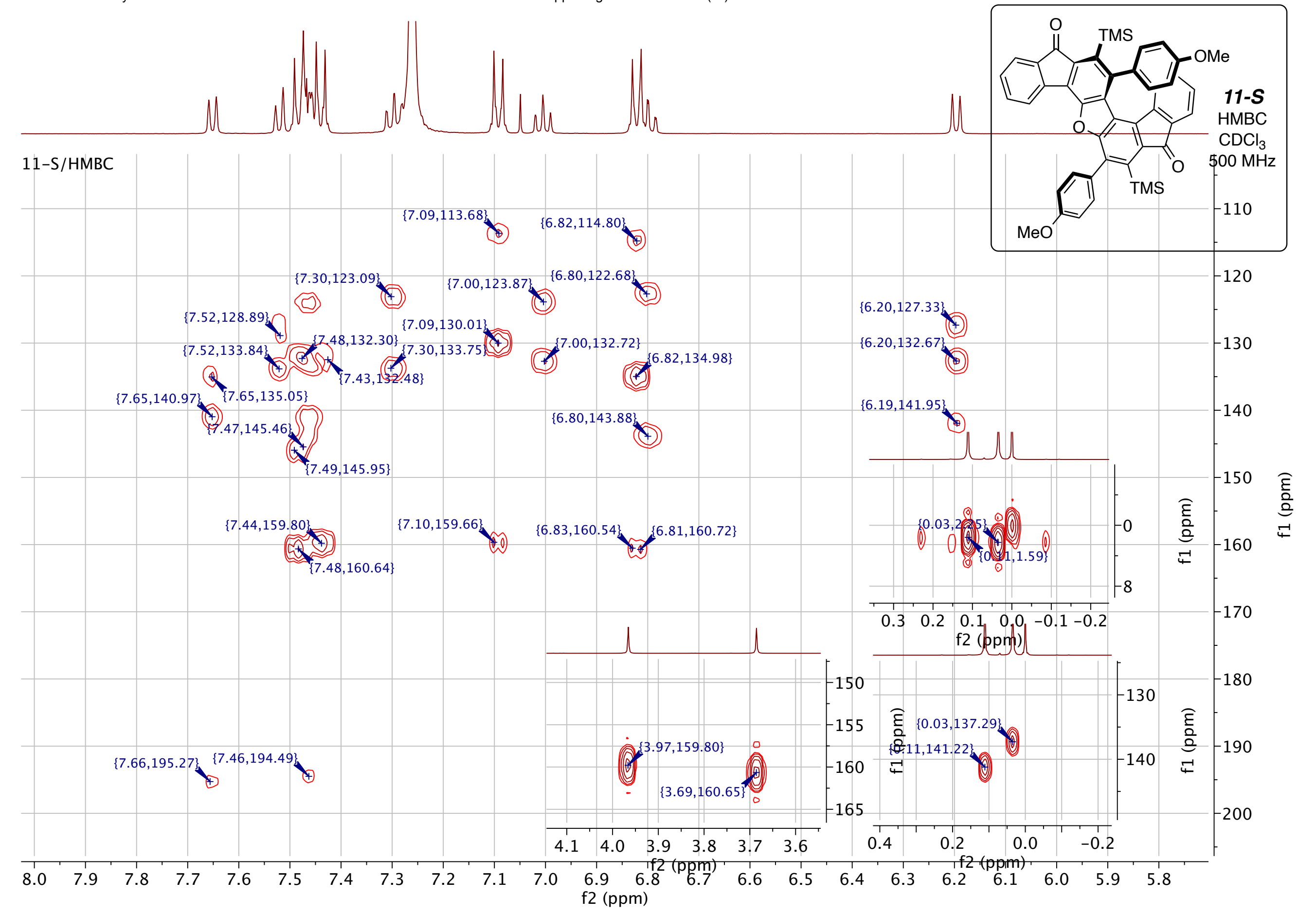


11-U/13C

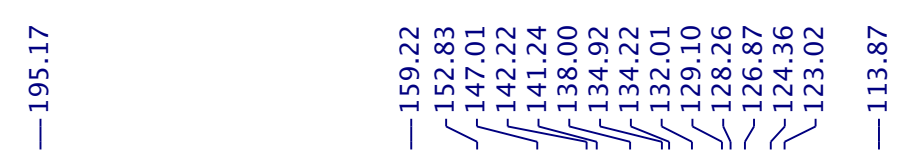

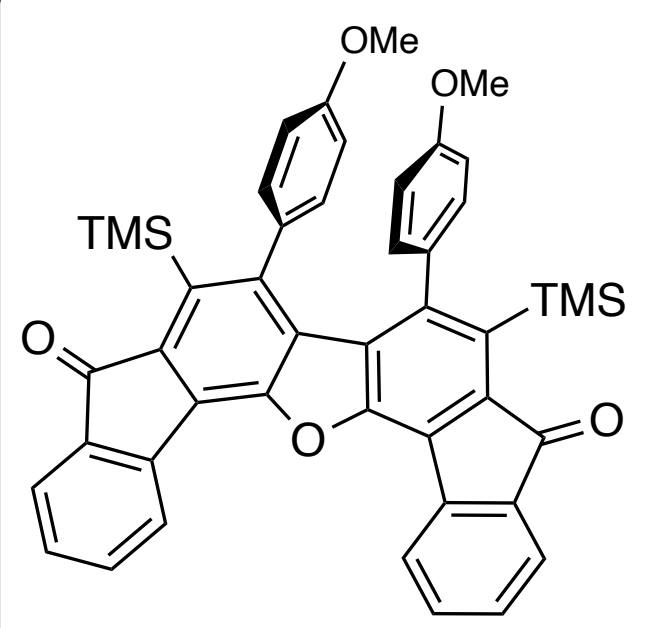

${ }^{13} \mathrm{C}$ NMR $\mathrm{CDCl}_{3}$ $500 \mathrm{MHz}$

i 

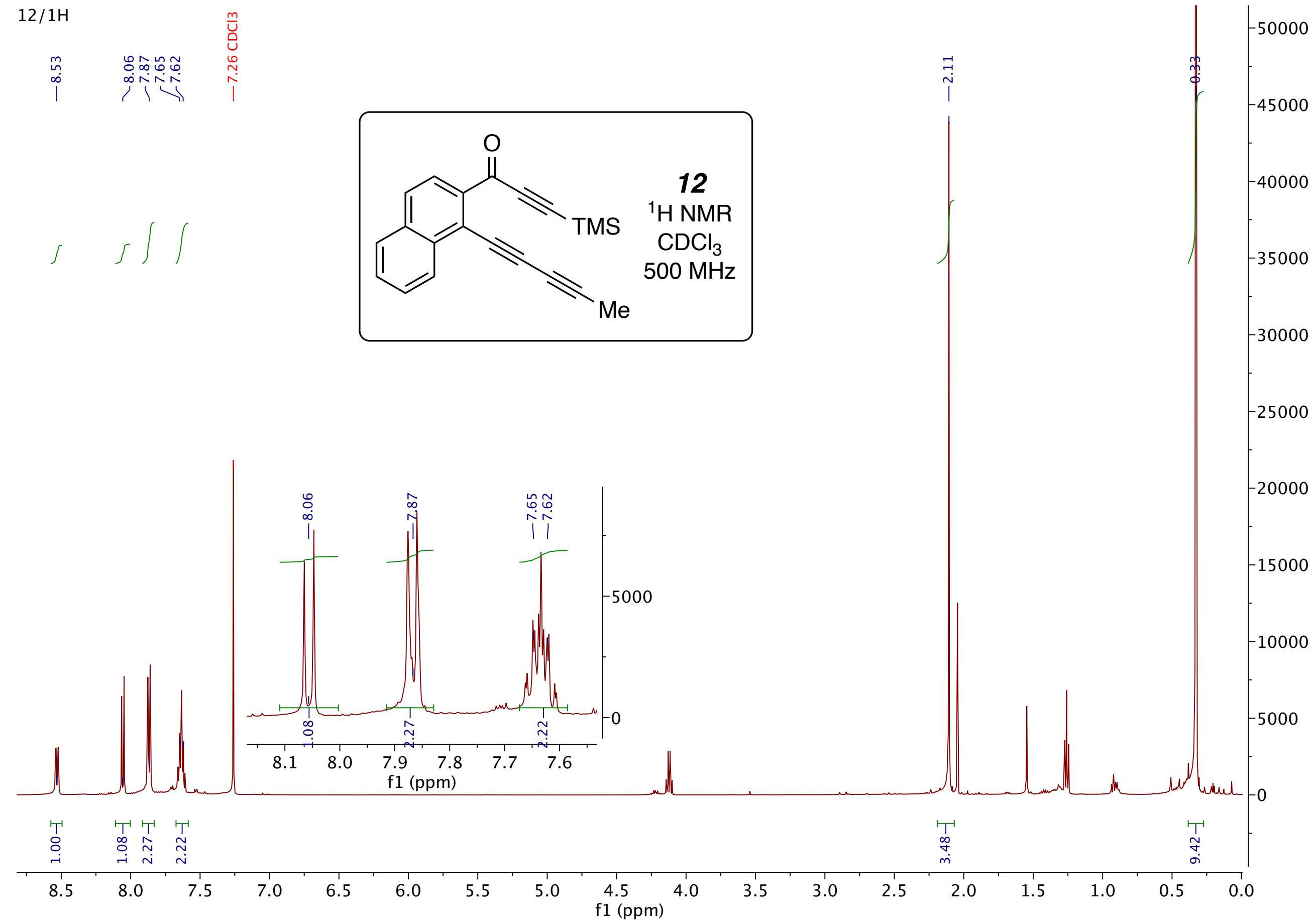

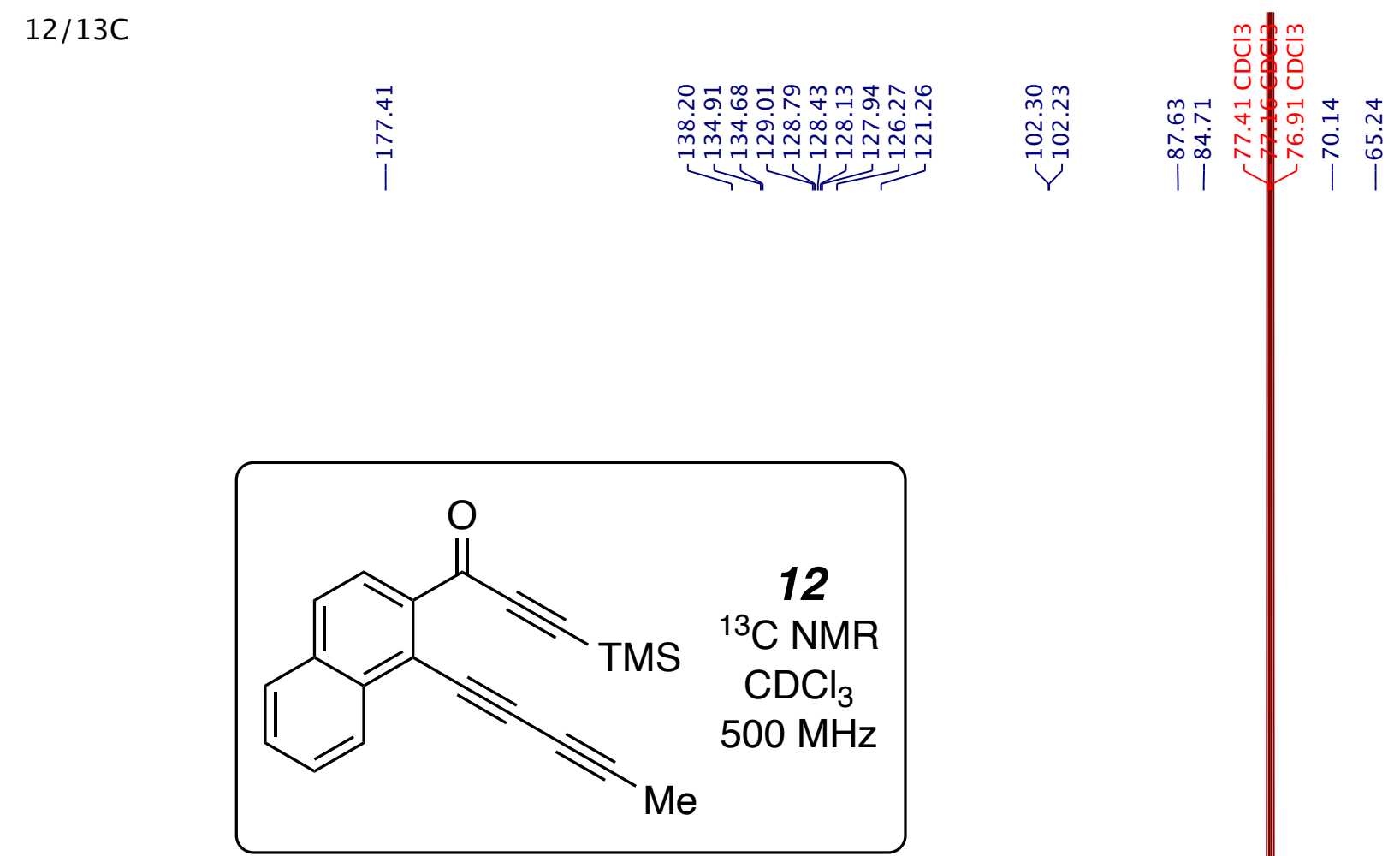

. 


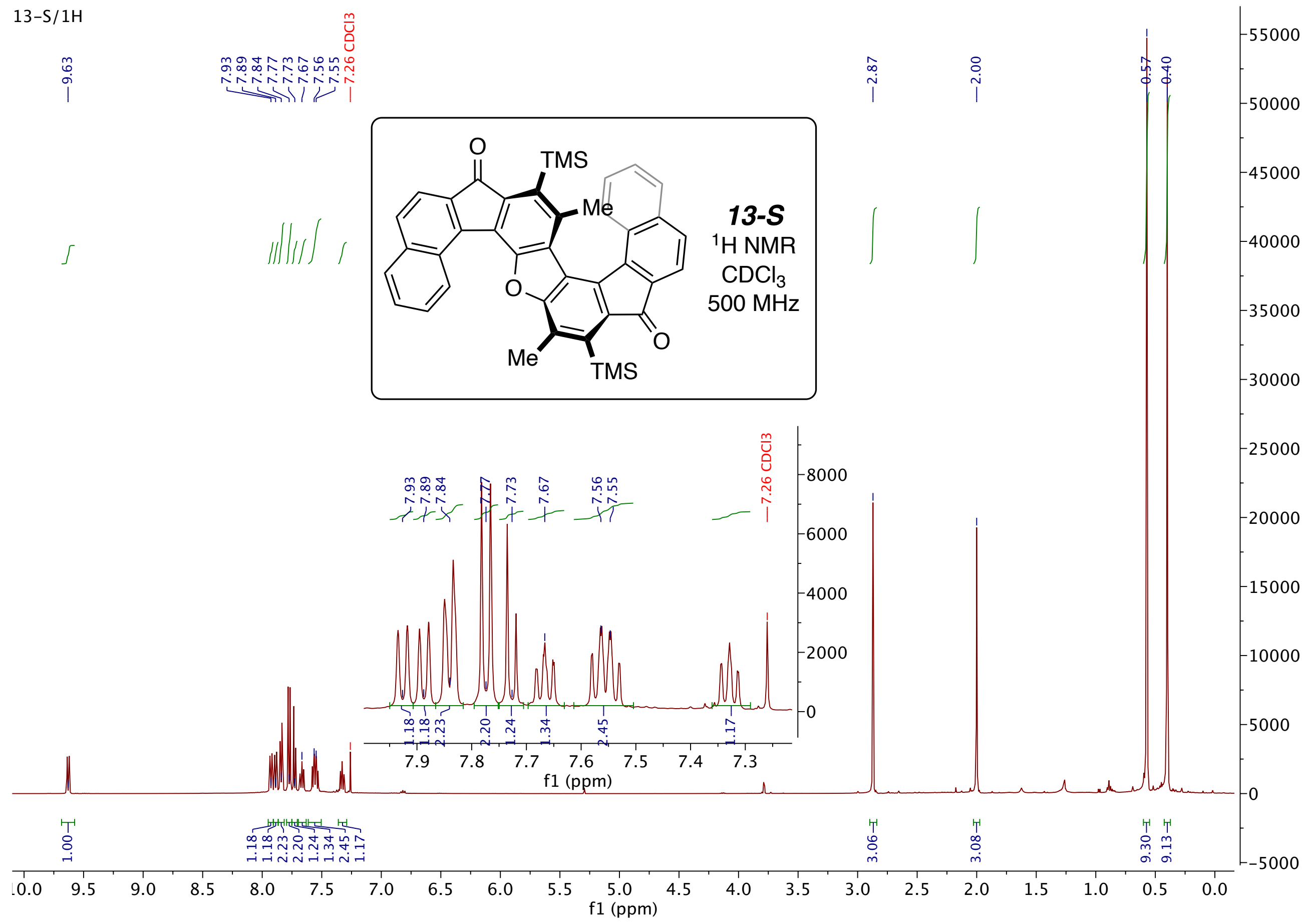



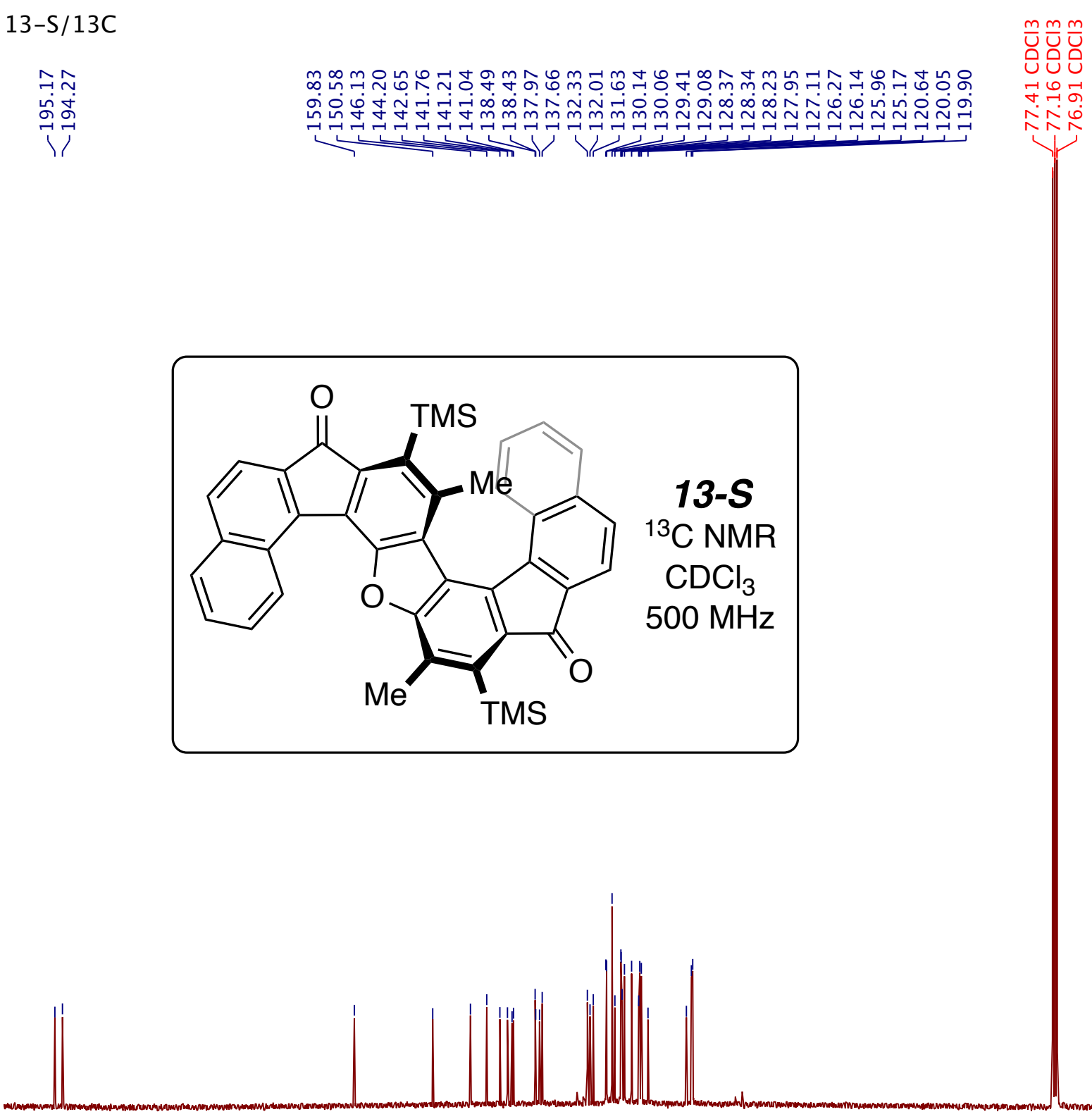


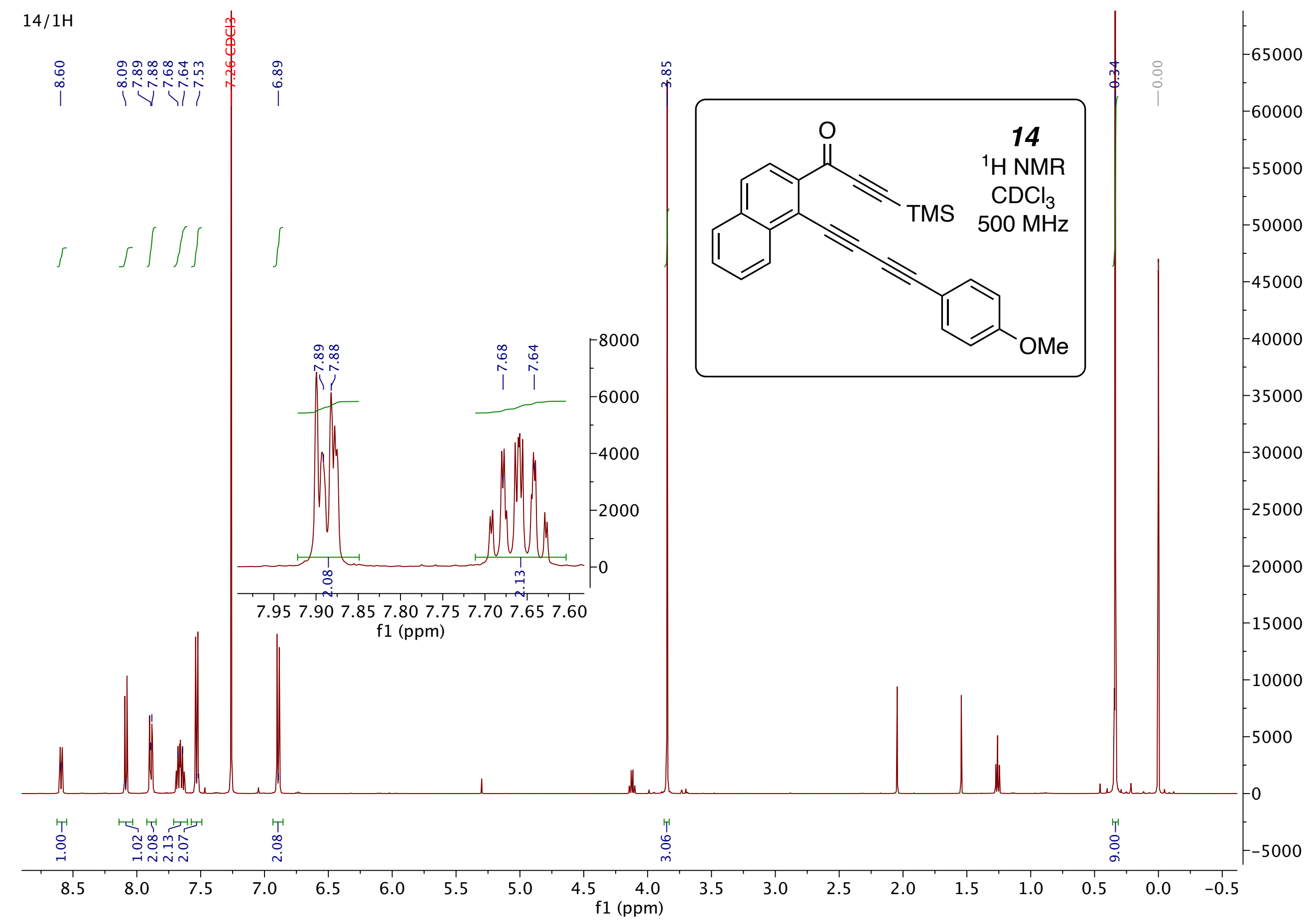



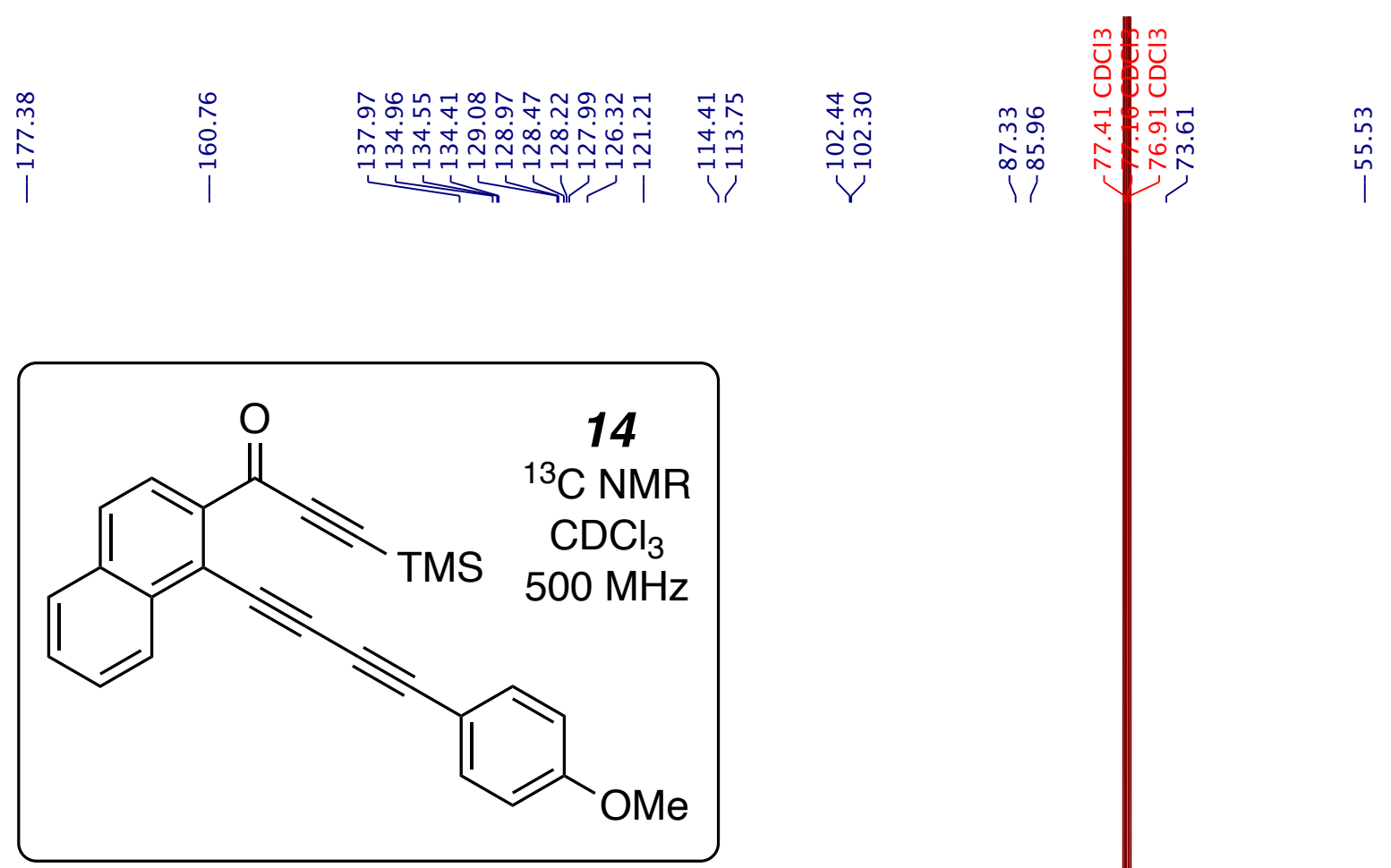

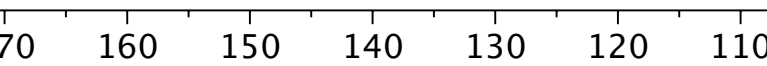




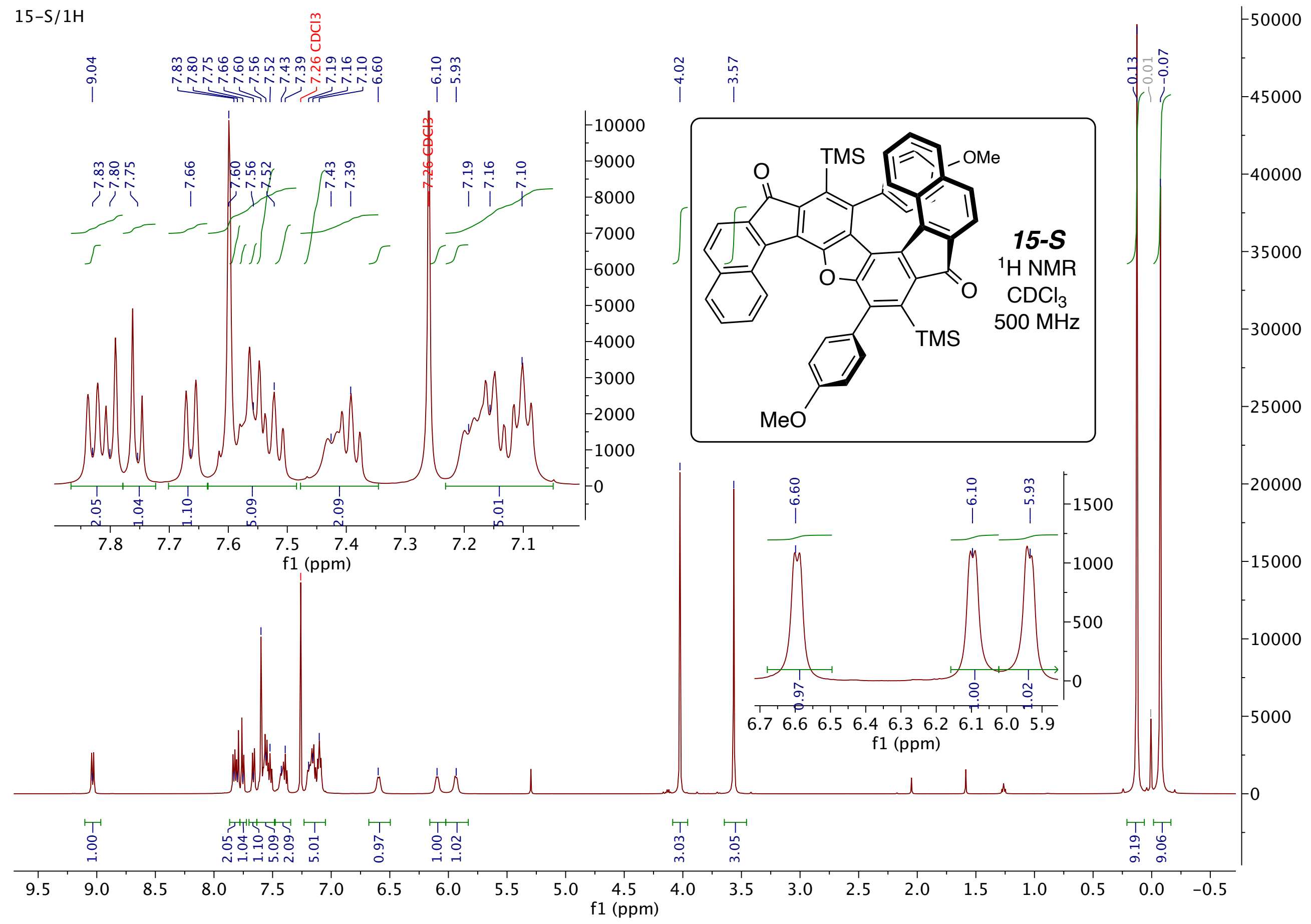



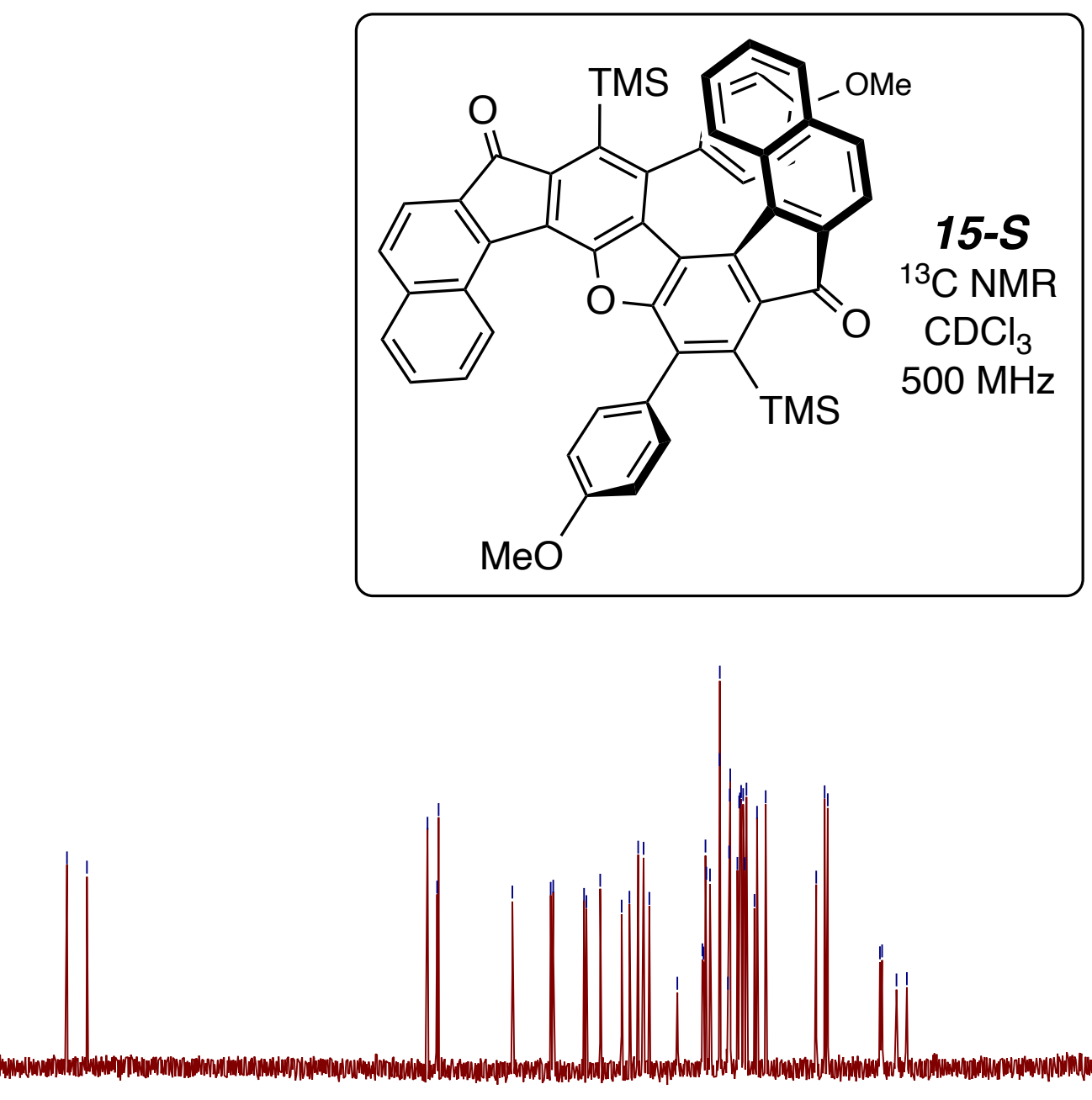

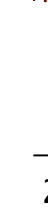



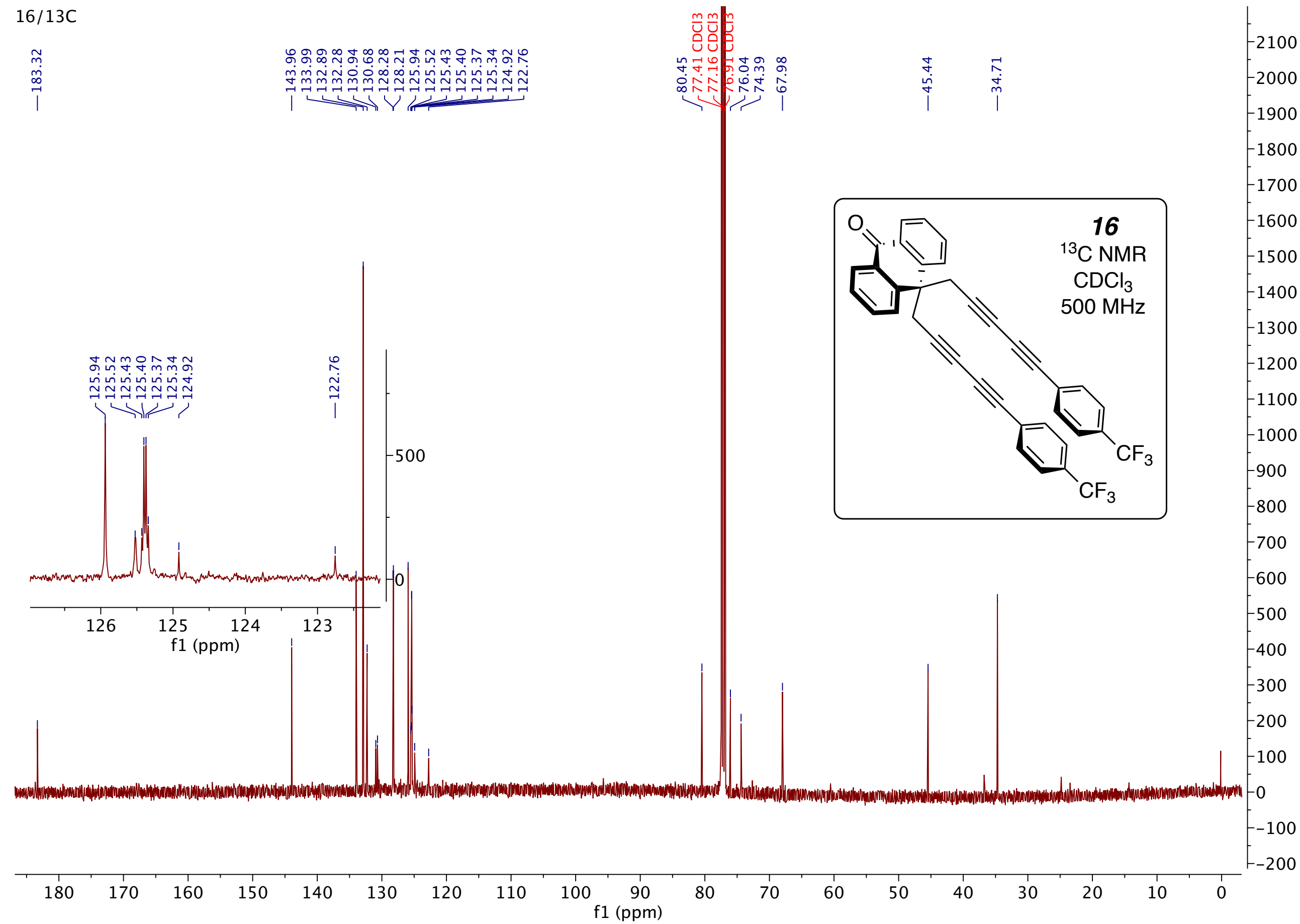


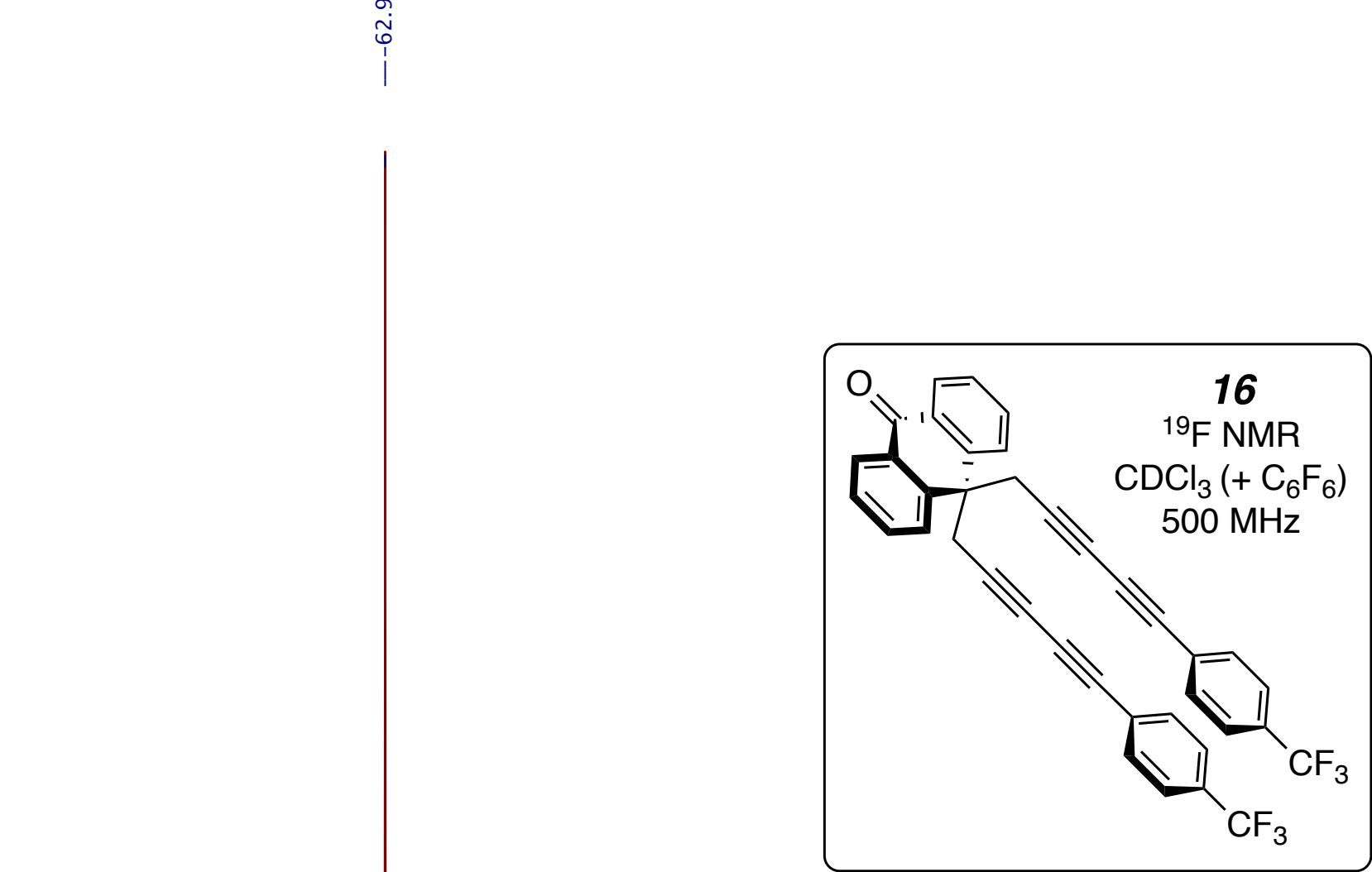



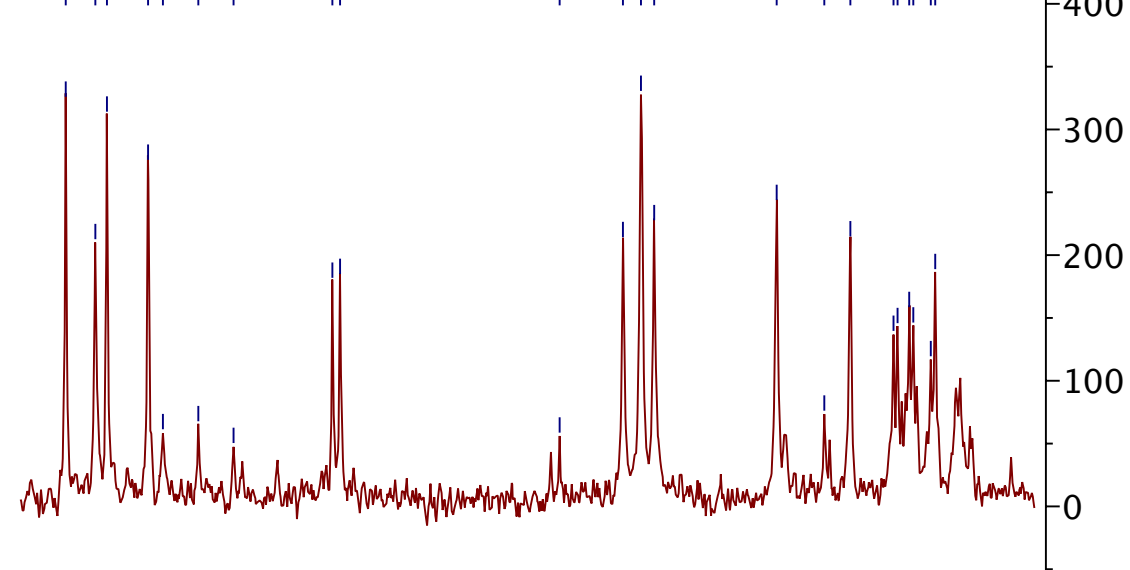

$132 \quad 131$

-500
-400
-300
-100
-0

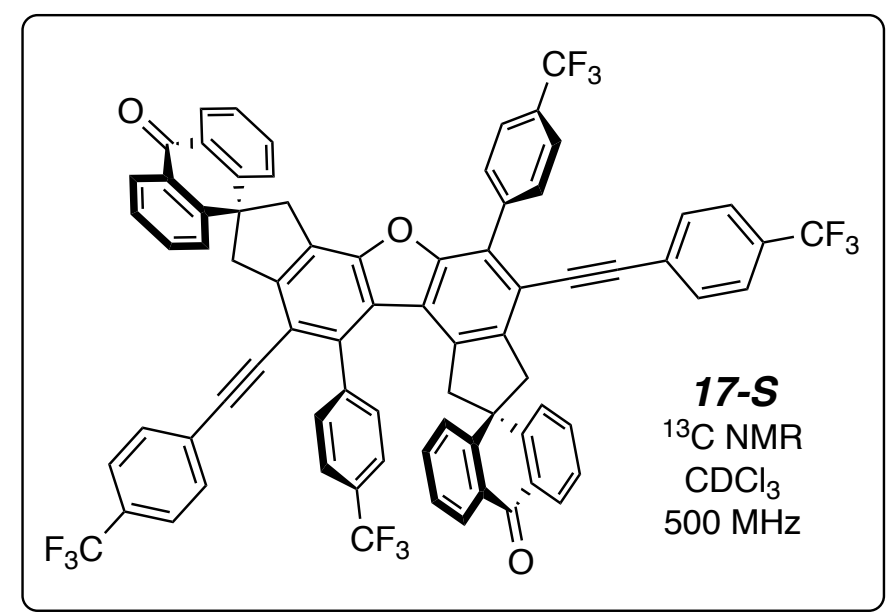




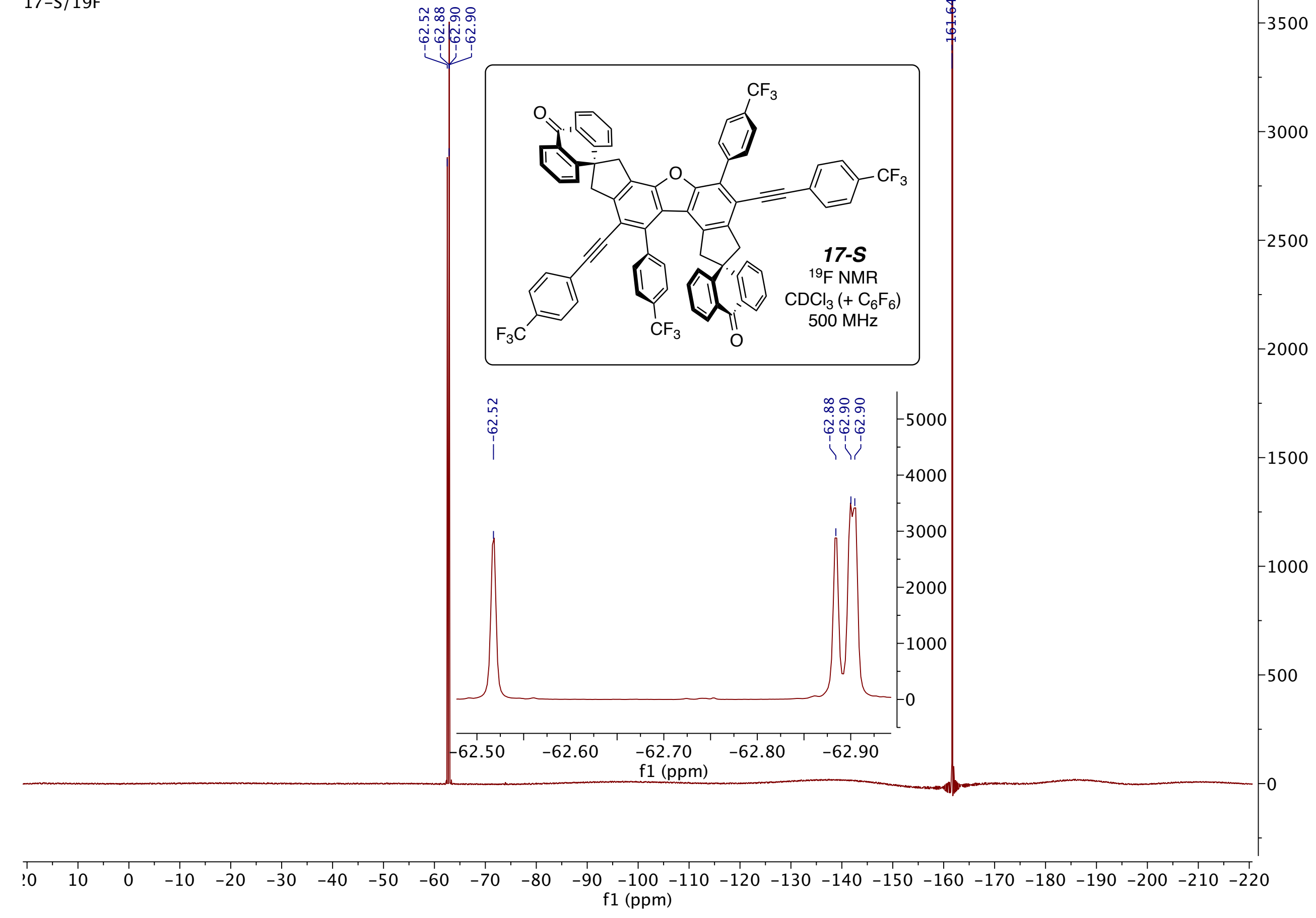




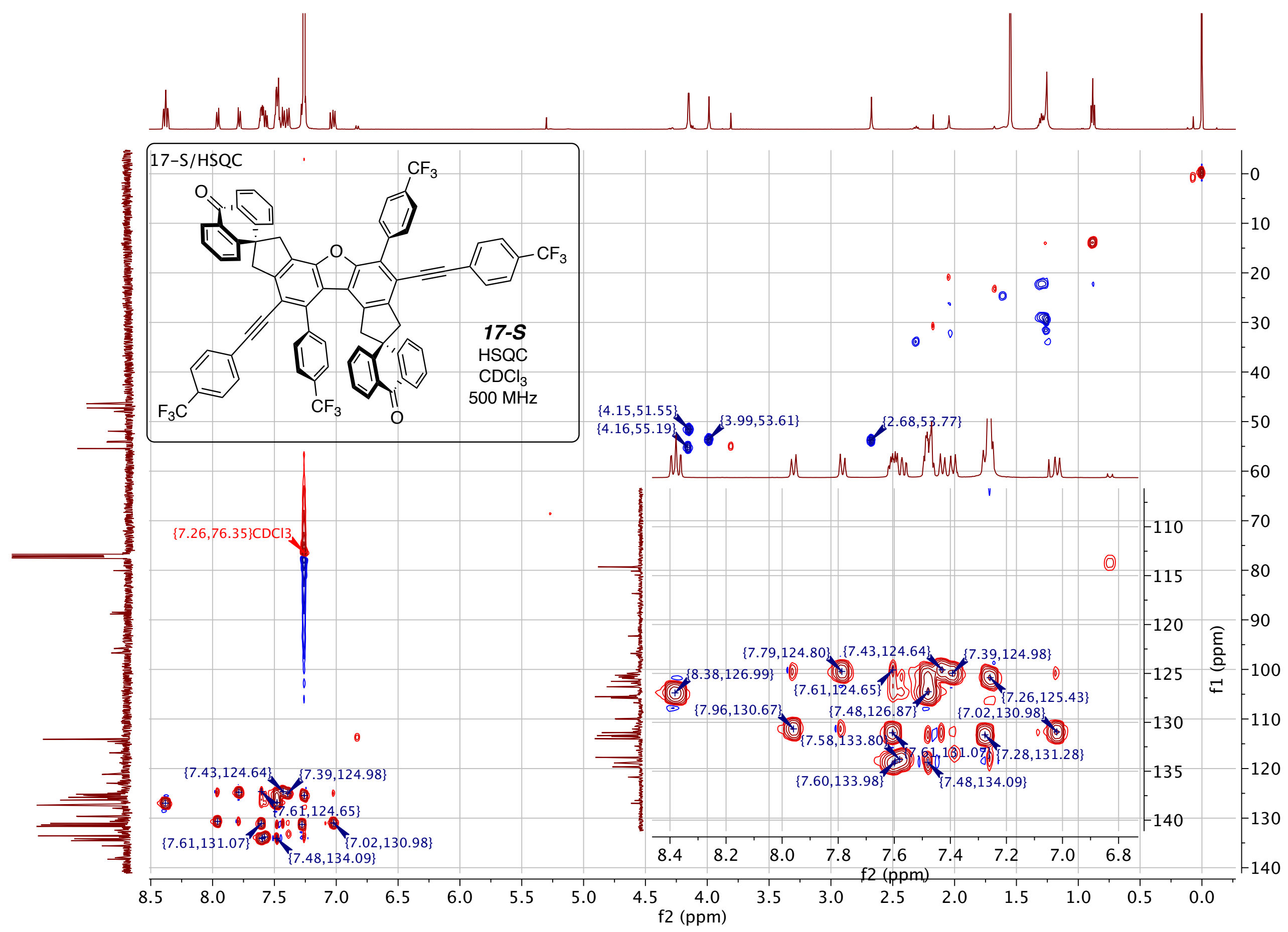



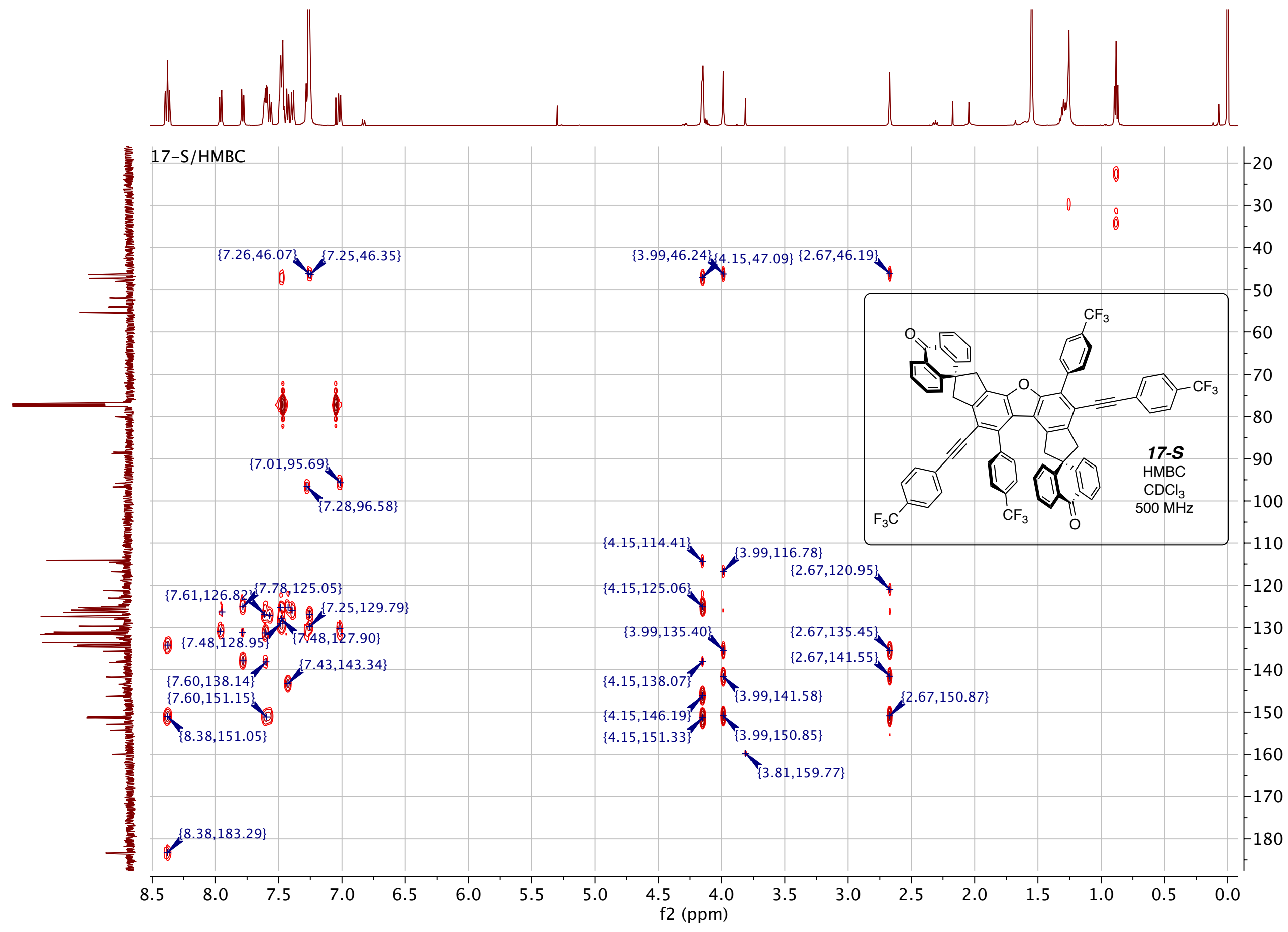


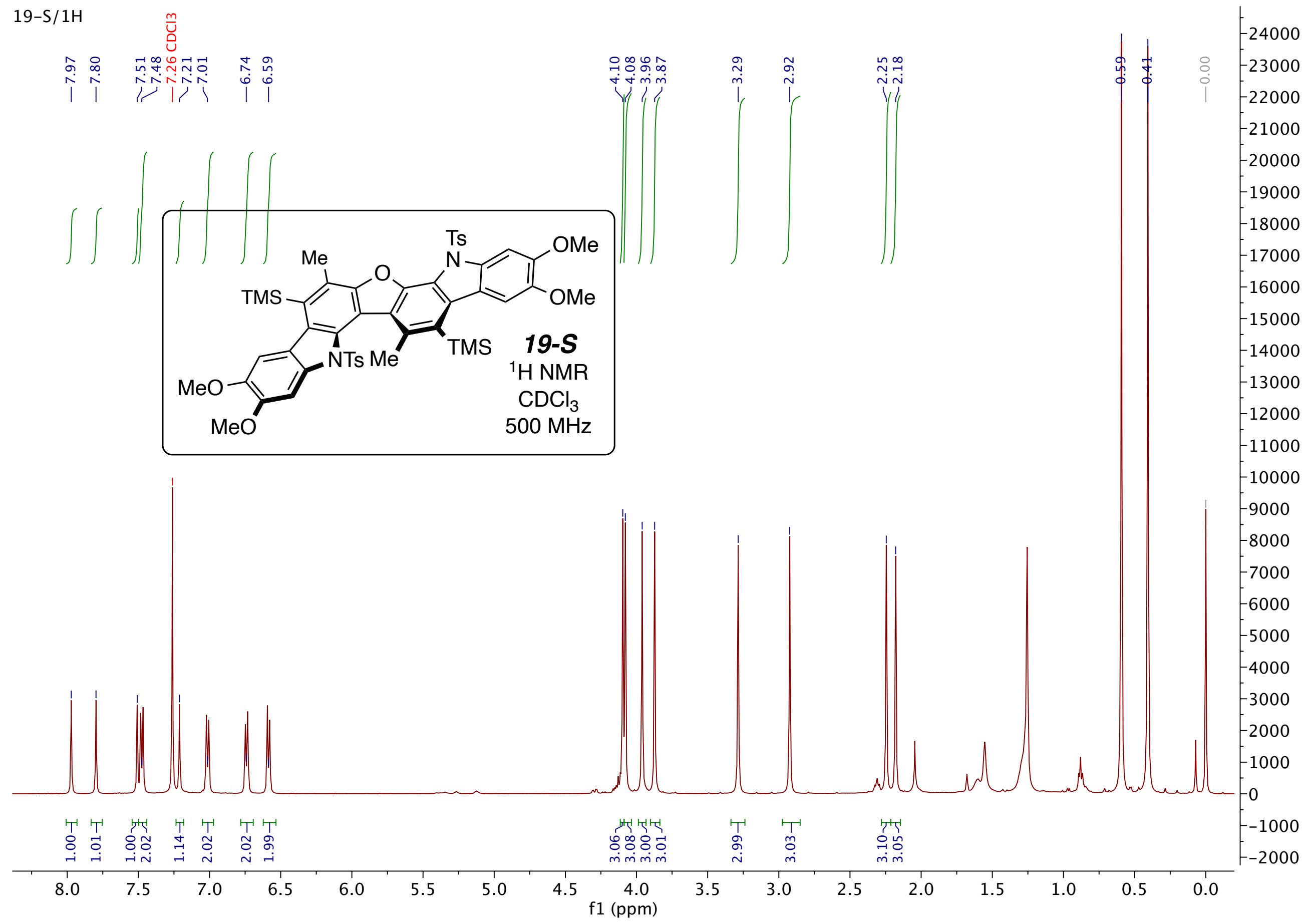



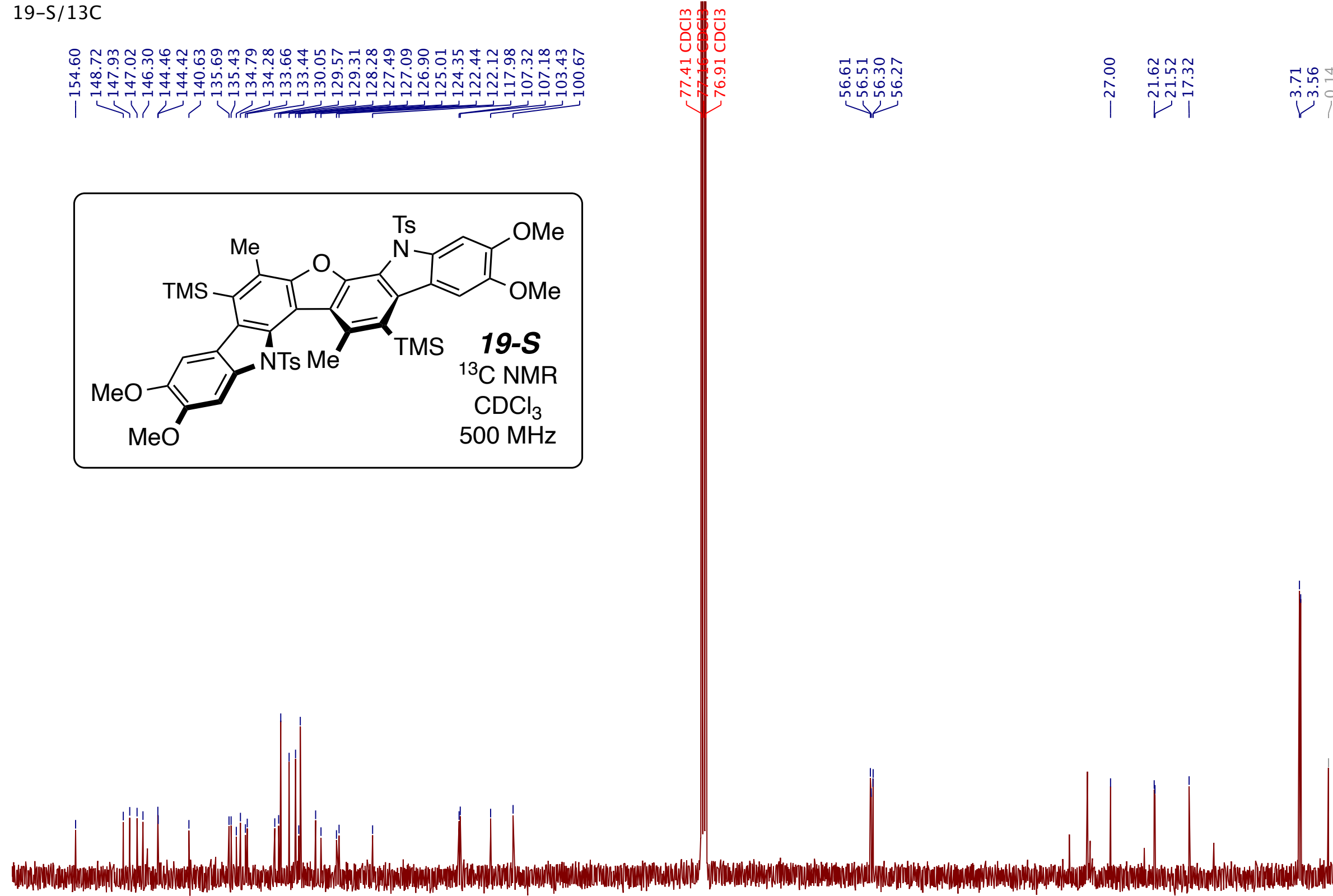


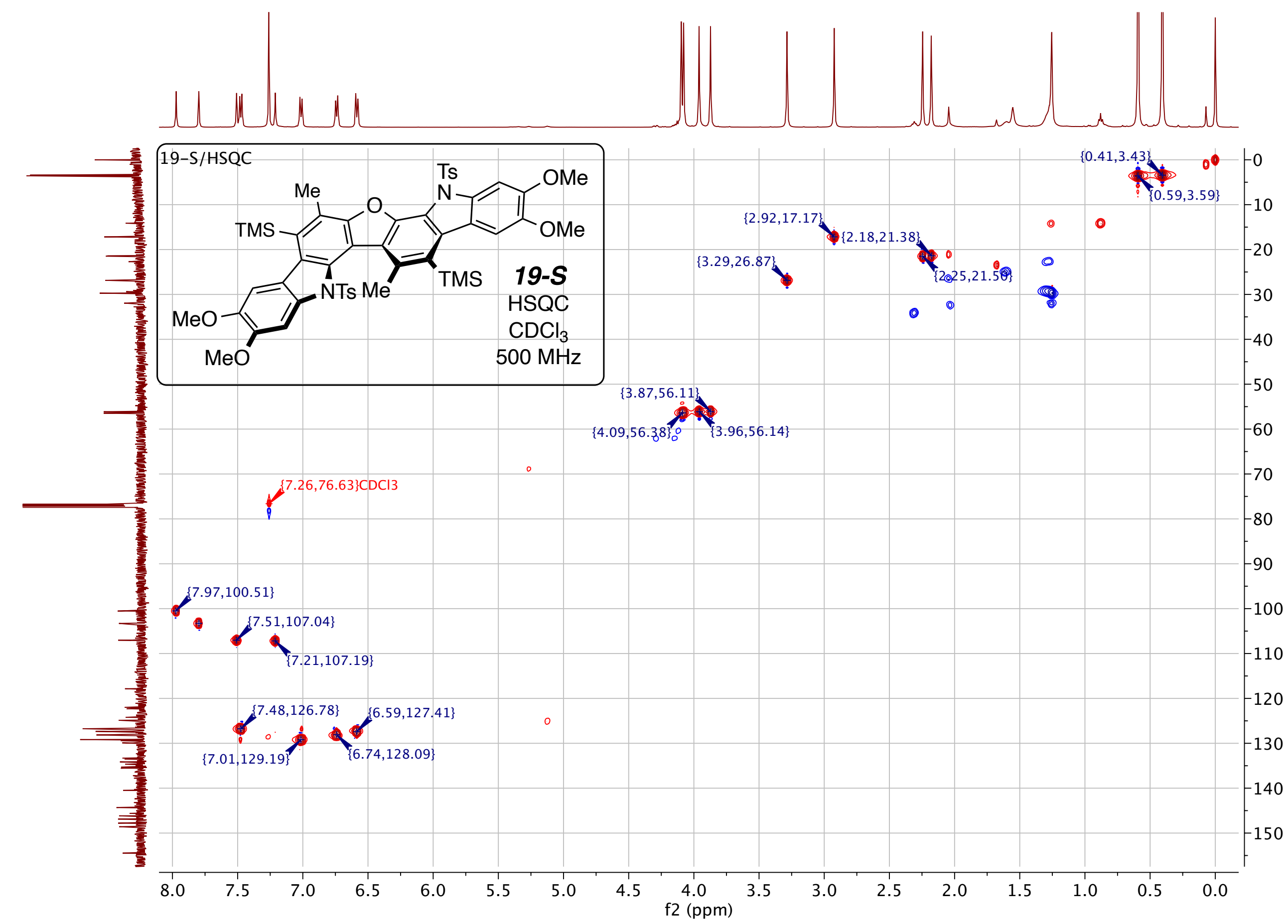




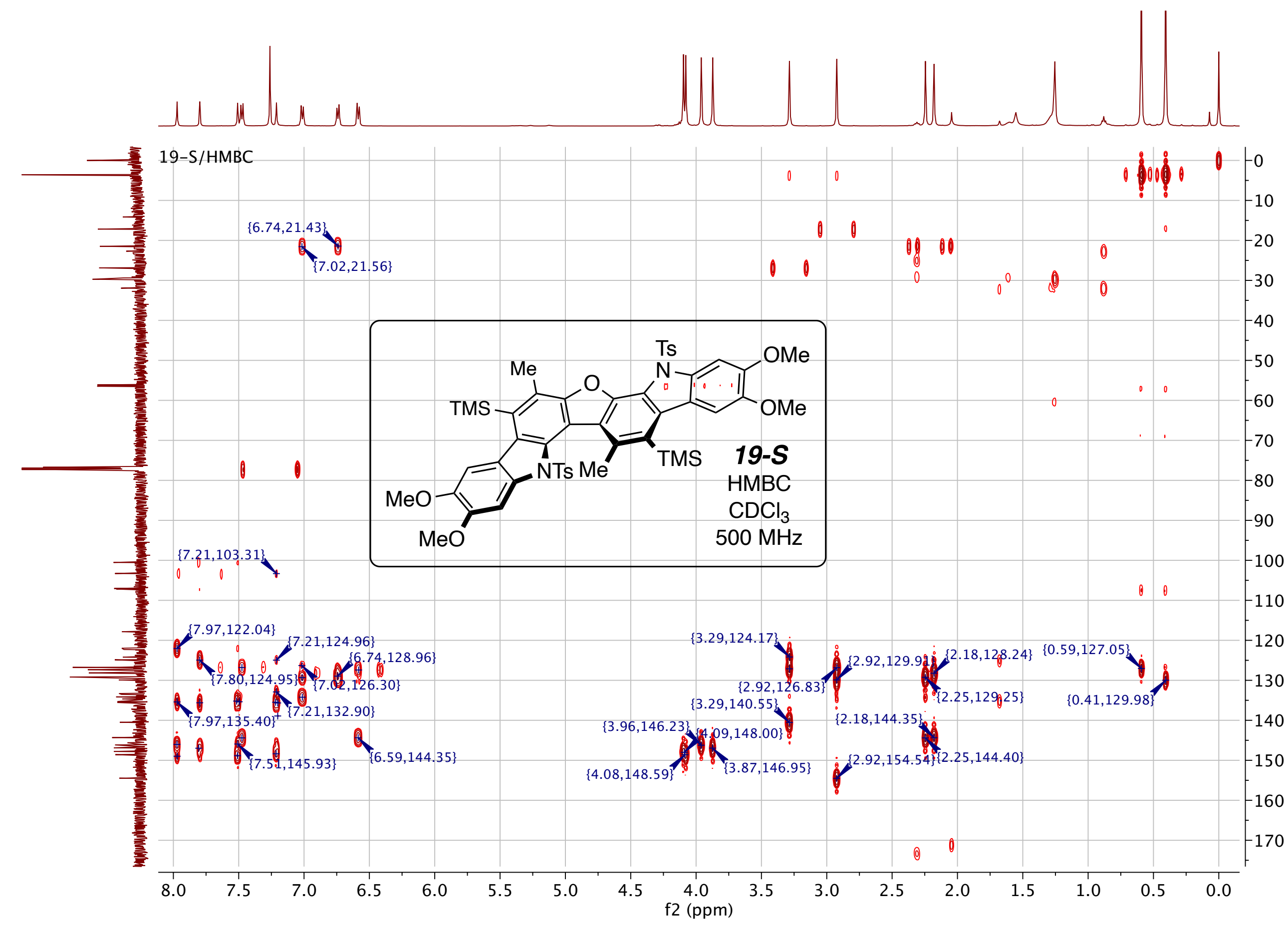




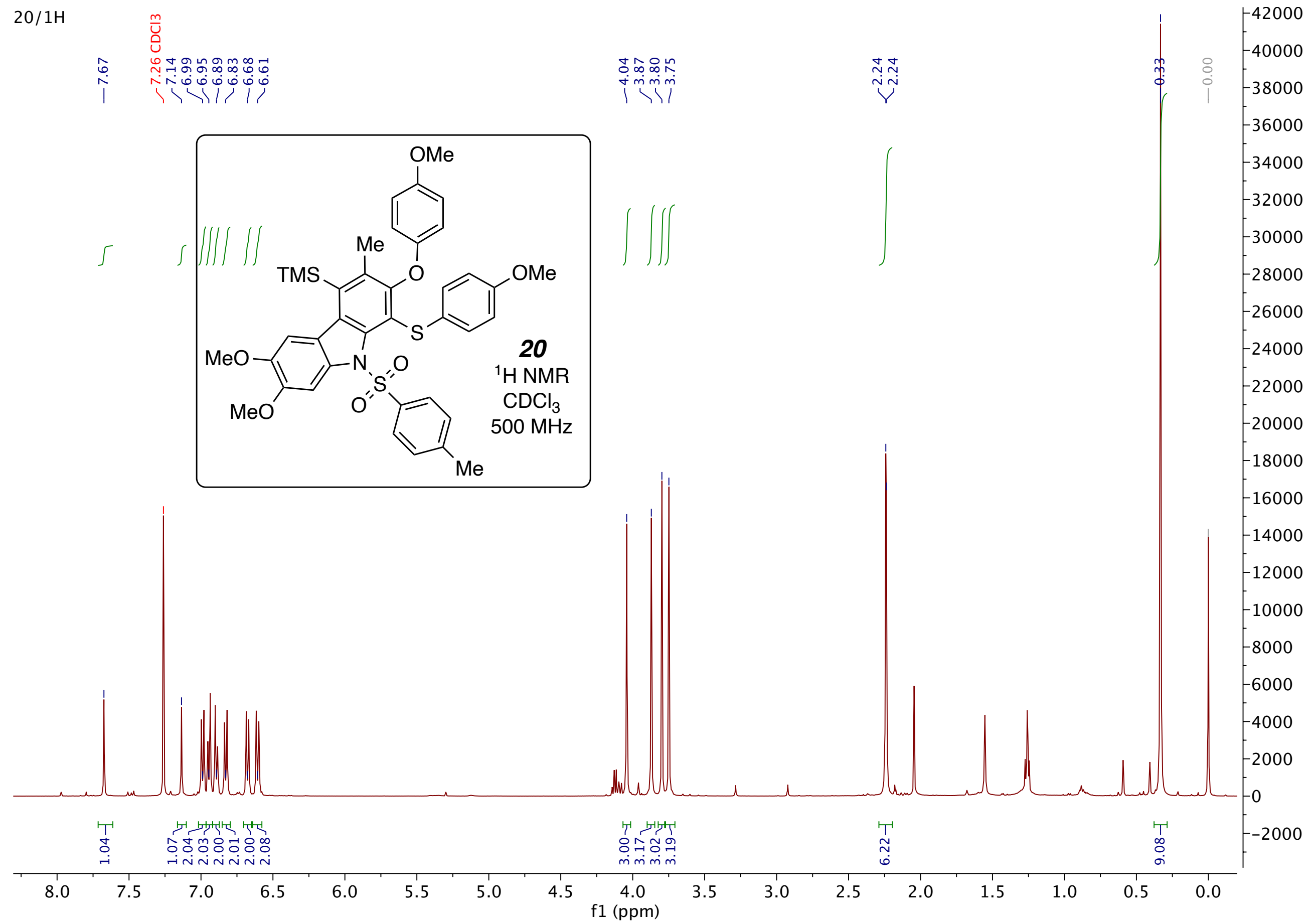



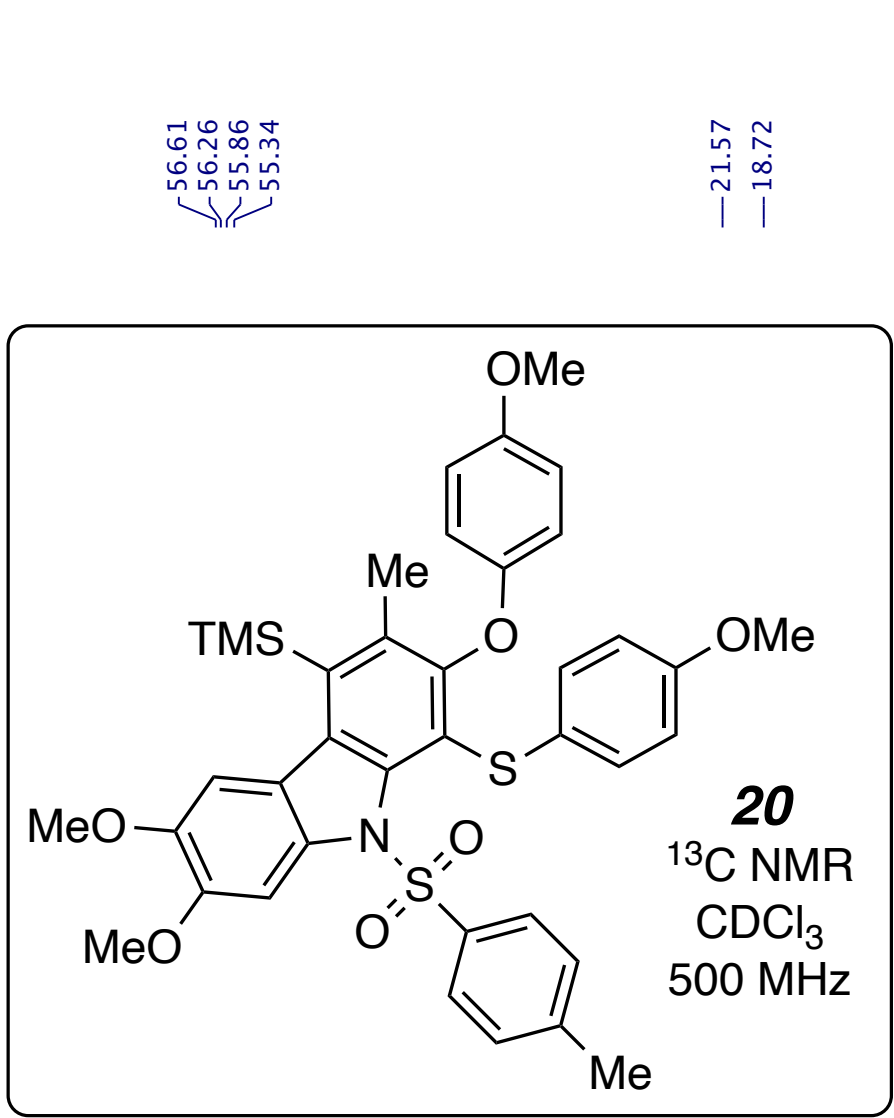

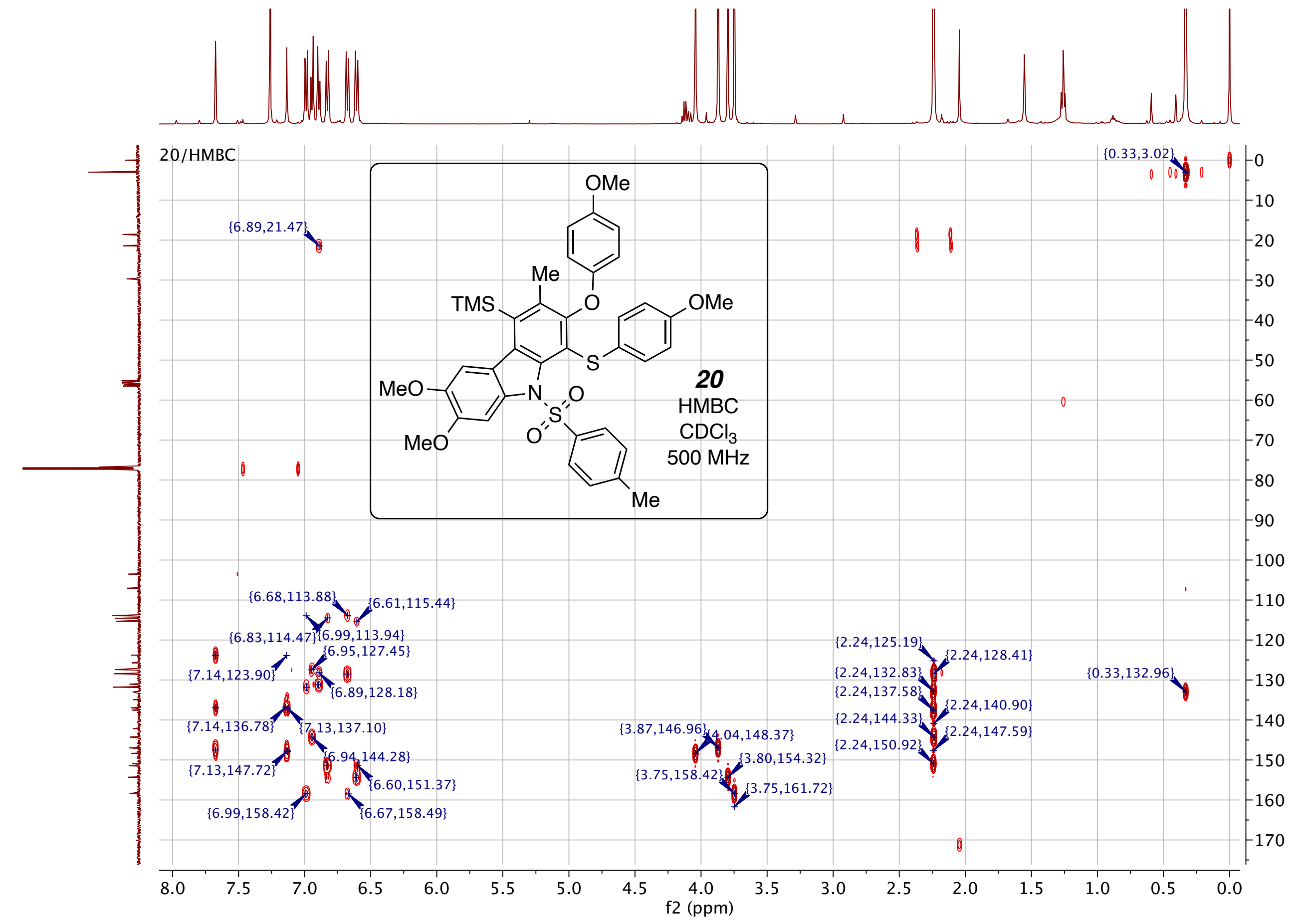


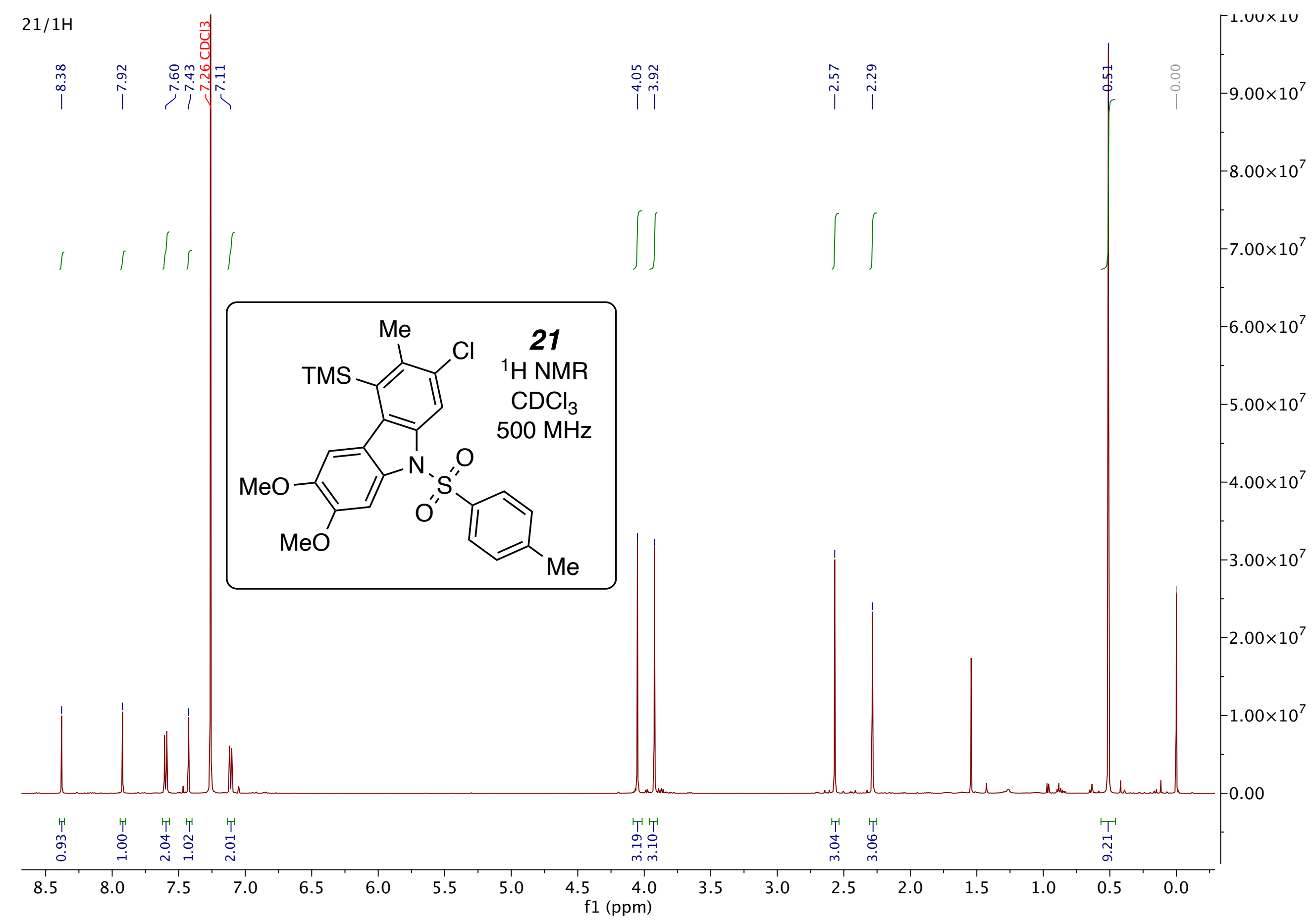



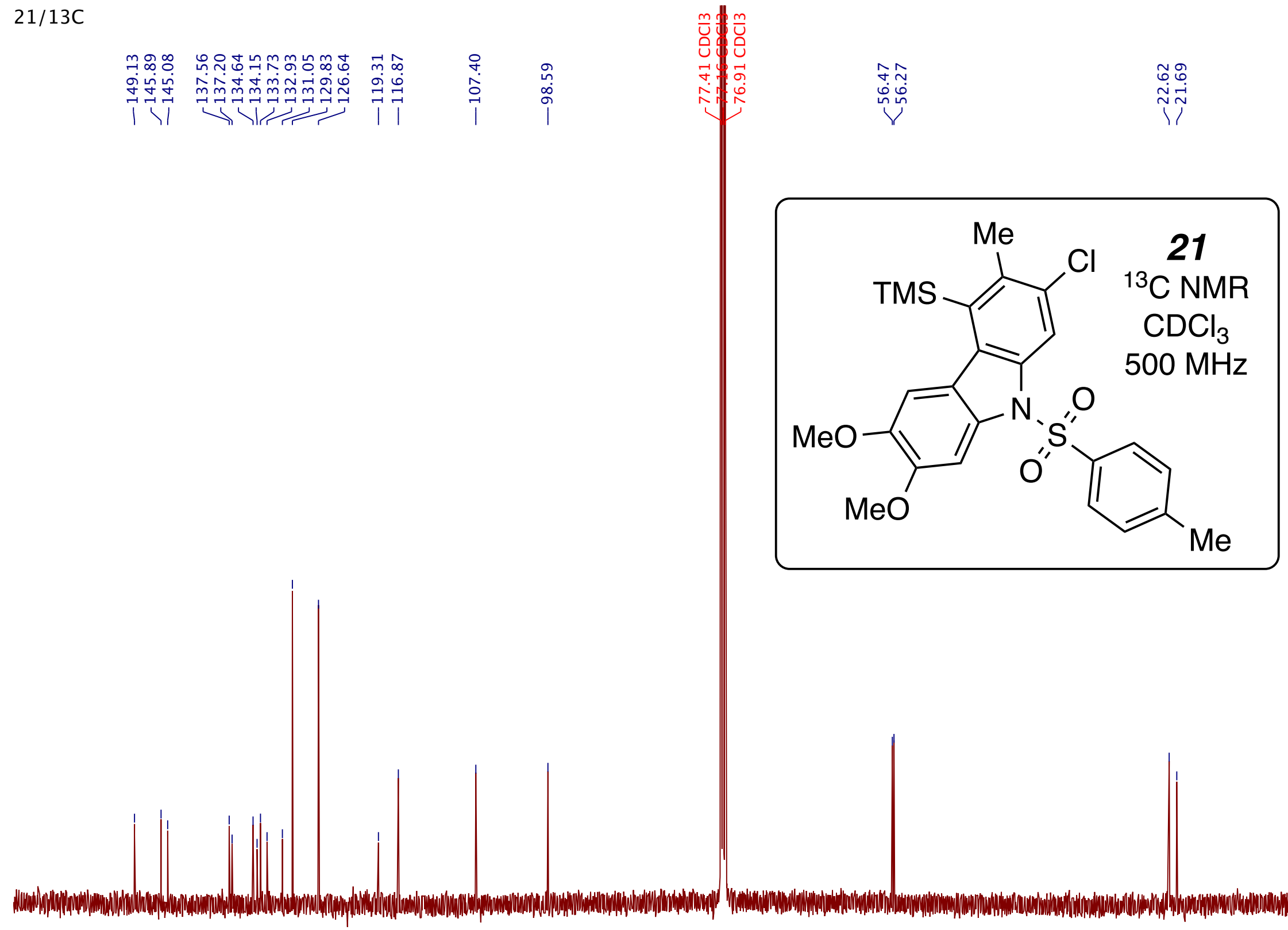

IsUU 

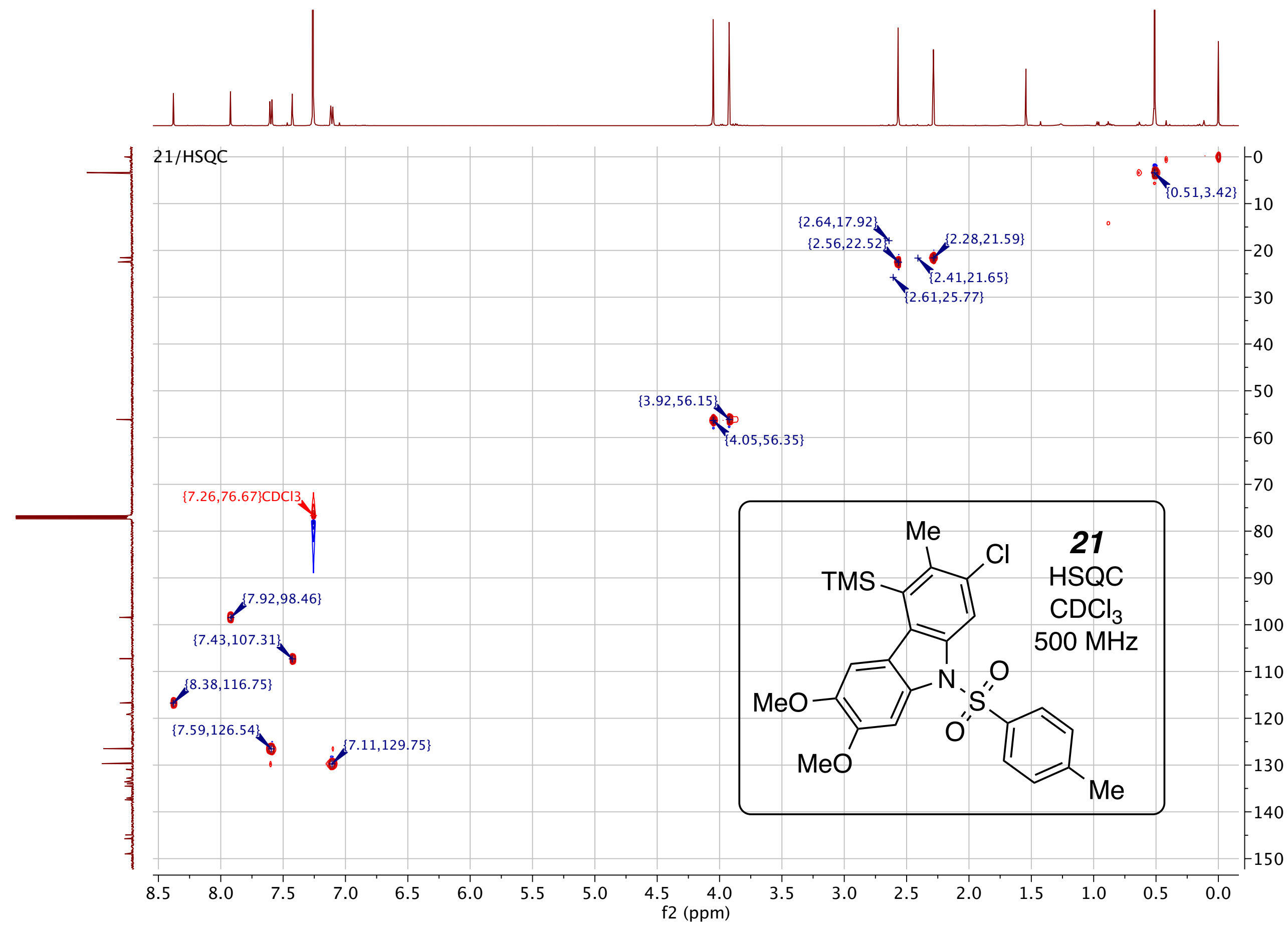

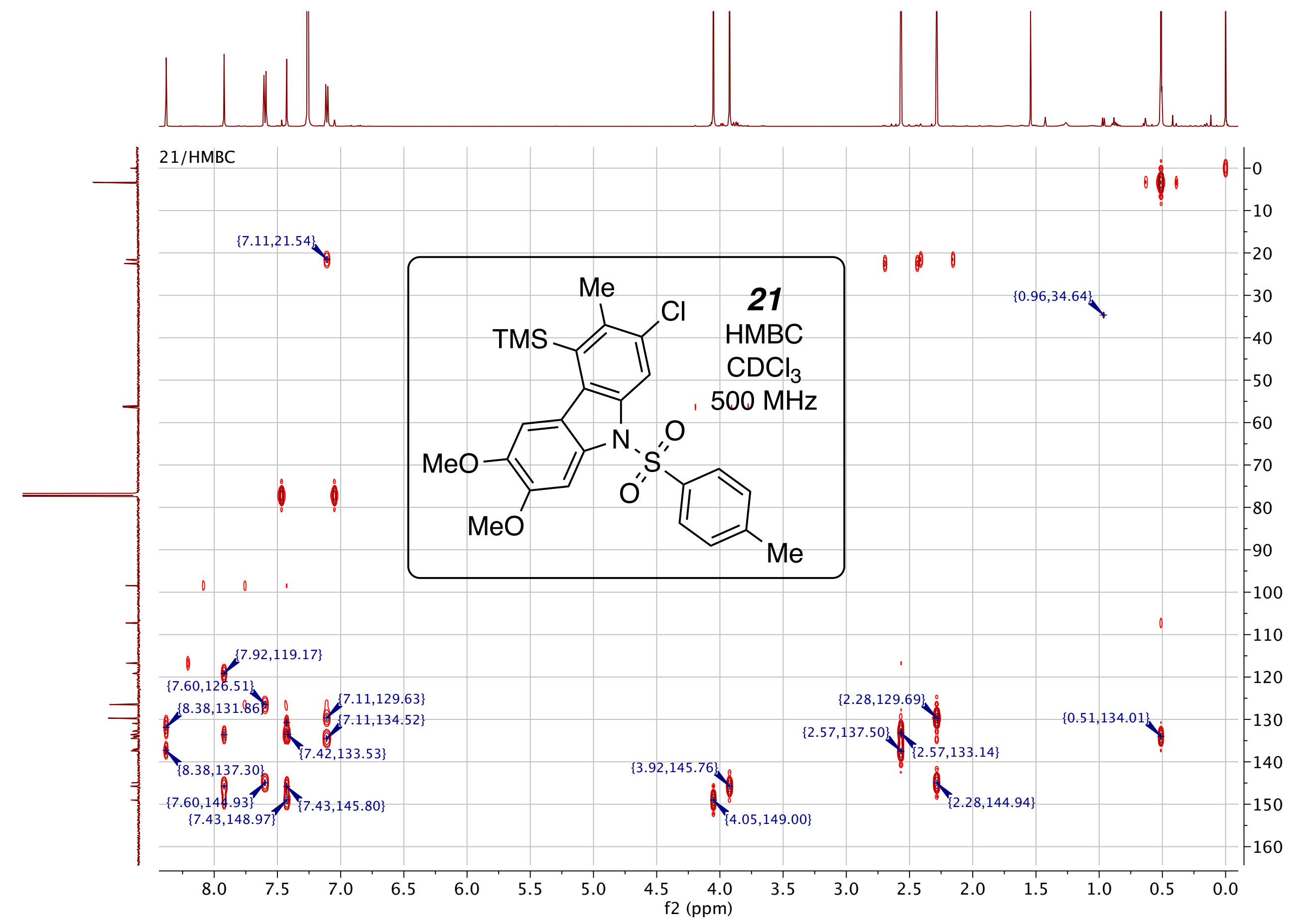

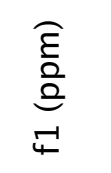




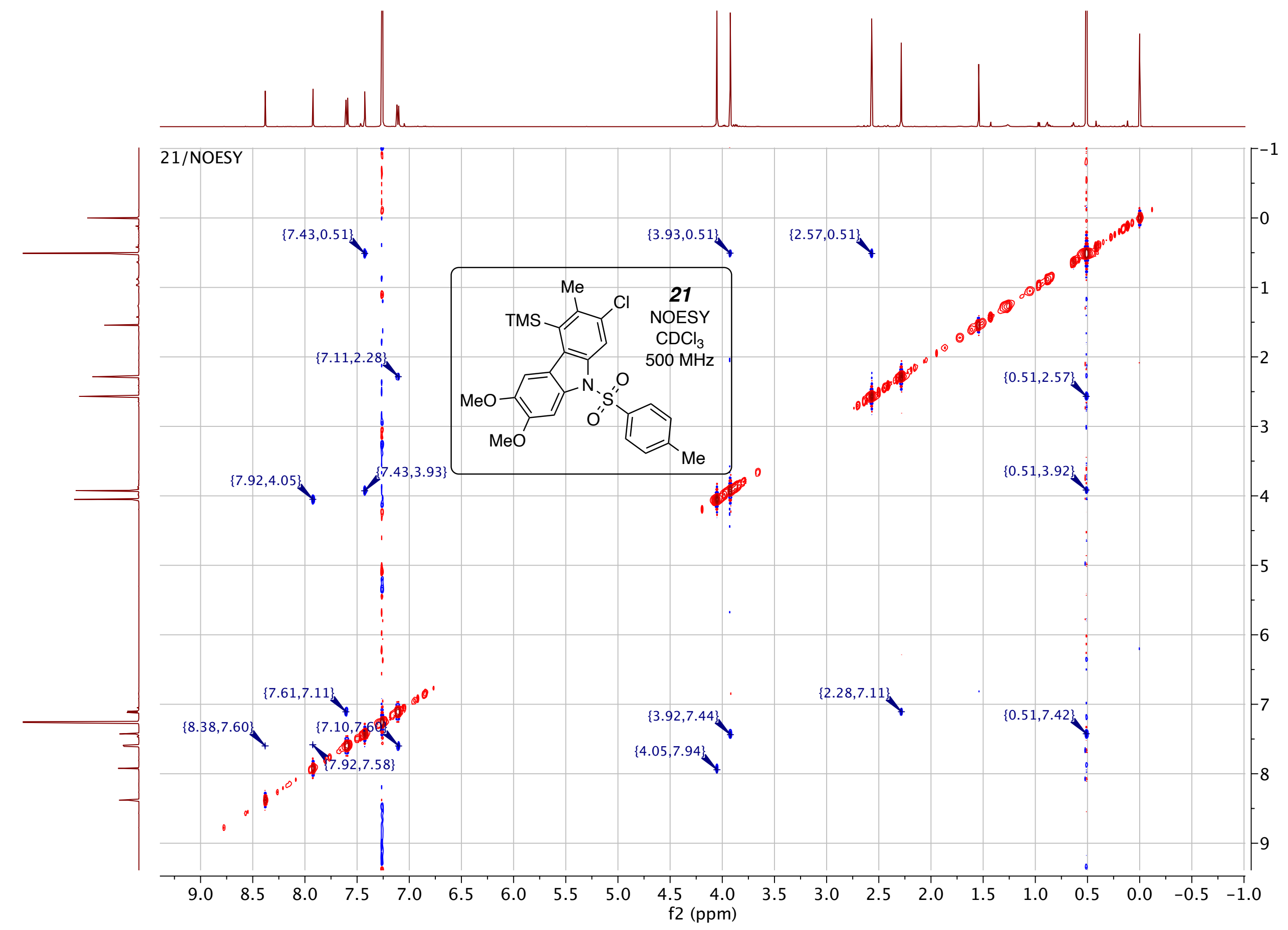

$\widehat{\varepsilon}$
$\bar{a}$
$\vec{b}$ 